\title{
Validierung des Sanierungsfortschrittes in der Paratuberkulosebekämpfung eines ausgewählten Milchviehbestandes bei Einsatz serologischer Diagnostikverfahren
}

\author{
Dissertation \\ zur Erlangung des Doktorgrades \\ der Fakultät für Agrarwissenschaften \\ der Georg-August-Universität Göttingen
}

vorgelegt von

Artsrun Karapetyan

geboren in Martuni, Armenien

Göttingen, Oktober 2009 
D 7

Referent:

Prof. Dr. Dr. C. P. Czerny

Korreferent:

Prof. Dr. Dr. M. Gauly

Tag der mündlichen Prüfung: 18.11.2009 



\section{INHALTSVERZEICHNIS}

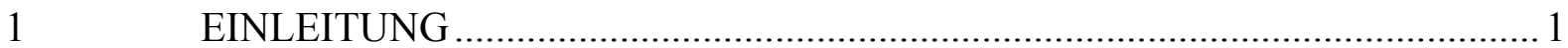

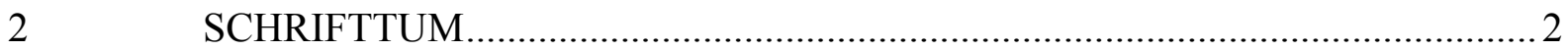

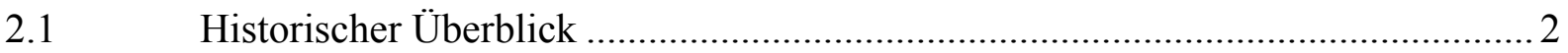

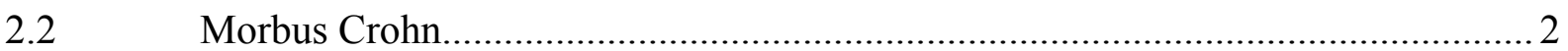

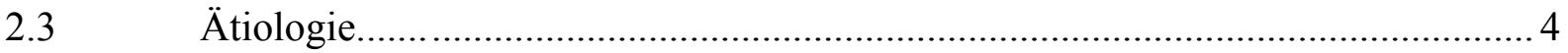

2.3.1 Morphologische Eigenschaften des Erregers .............................................. 4

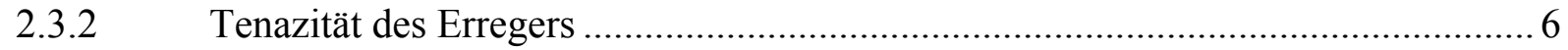

2.3.3 Klinisches Bild, Pathogenese und Immunantwort ........................................... 8

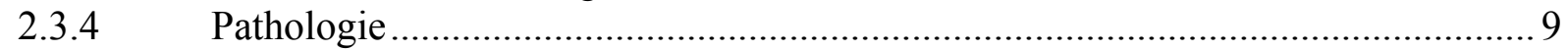

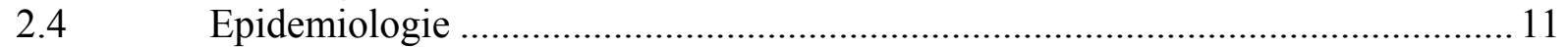

2.4.1 Geografische Verbreitung in Nutztierbeständen ................................................. 11

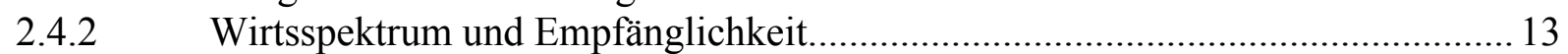

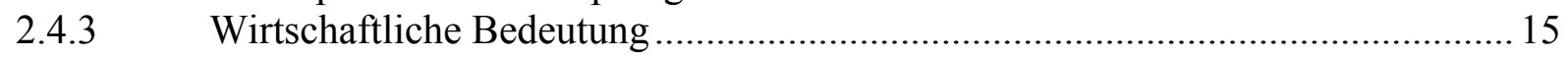

2.4.4 Vorkommen, Übertragung und Ausscheidung ............................................. 17

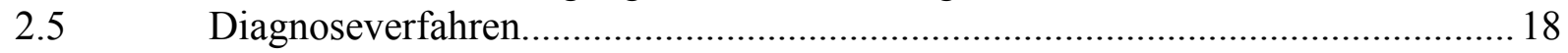

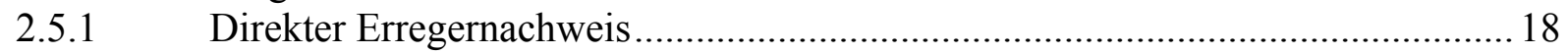

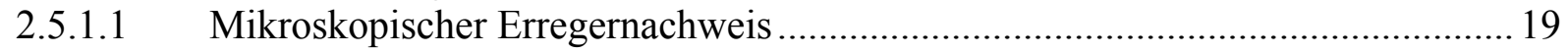

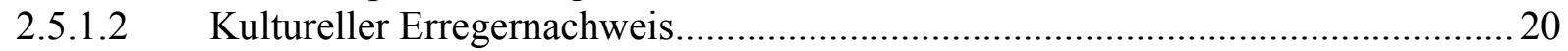

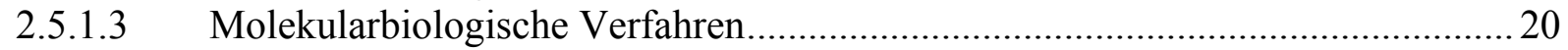

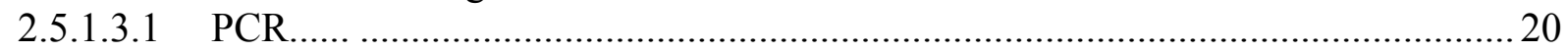

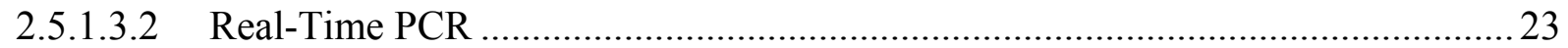

2.5.1.3.3 Restriction Fragment Length Polymorphismus (RFLP) ................................... 26

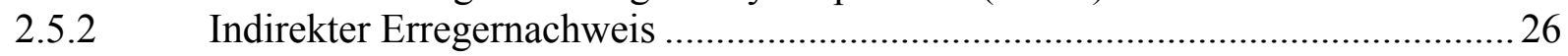

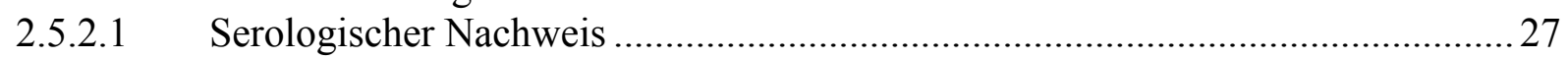

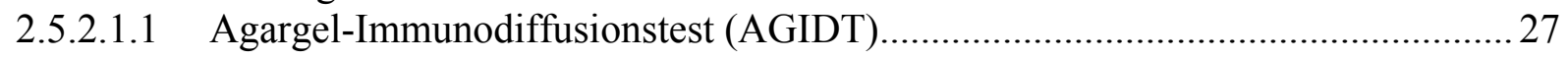

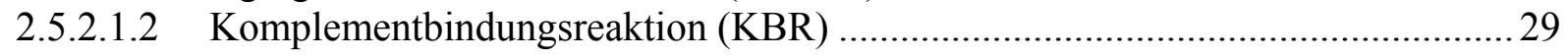

2.5.2.1.3 Enzyme-Linked Immunosorbent Assay (ELISA) ......................................... 31

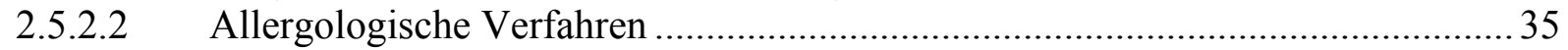

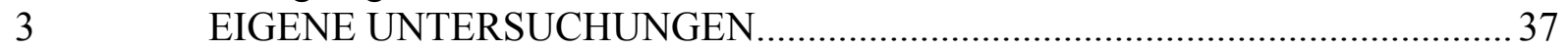

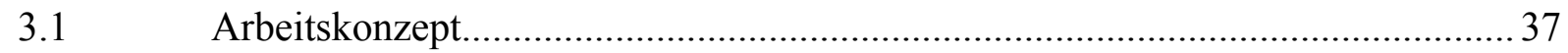

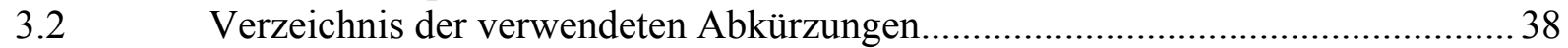

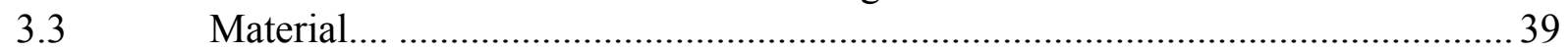

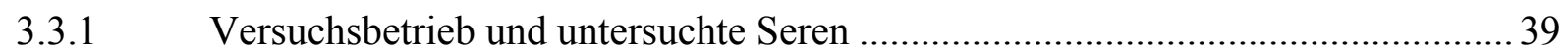

3.3.2 Betriebsstruktur und Hygienemaßnahmen des untersuchten

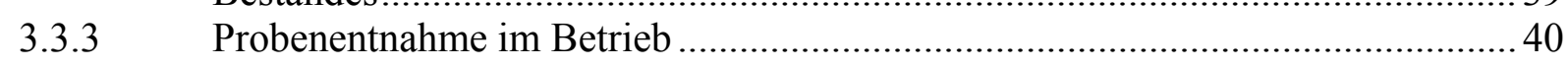

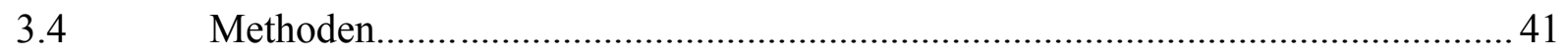

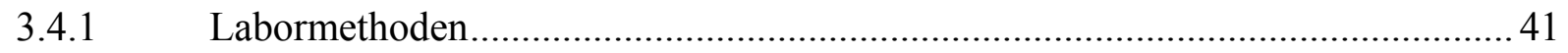

3.4.1.1 ELISA-Technik (Enzyme Linked Immuno Sorbent Assay) .............................. 41

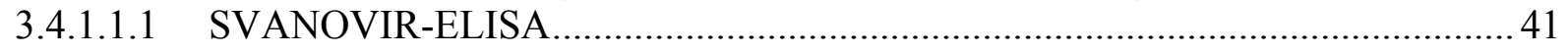

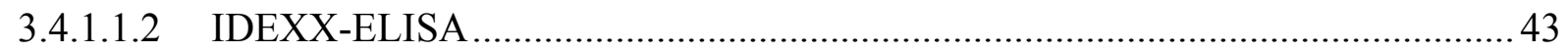

3.4.1.2 Molekulabiologische Methoden ................................................................ 45

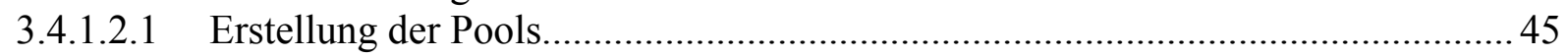

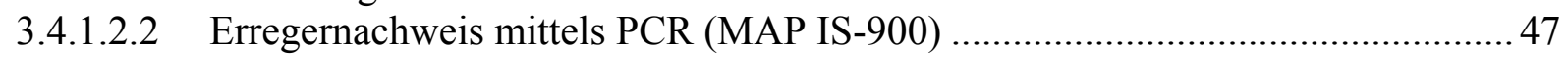

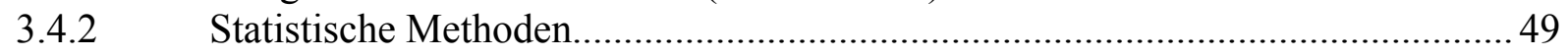

3.4.2.1 Bestimmung der Korrelation von IDEXX-und Svanovir-ELISA ....................... 49 
3.4.2.2 Verwendung des GLMM (generalized linear mixed model) zur statistischen Analyse der Korrelation von SVANOVIR_optischer Dichte und IDEXX optischer Dichte.............................................................. 49

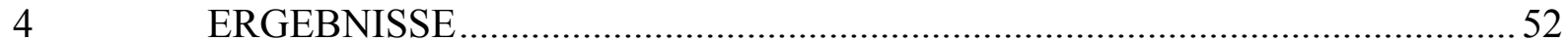

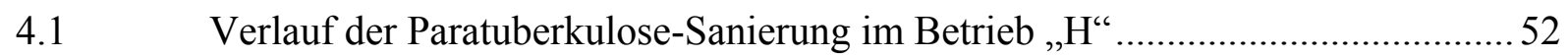

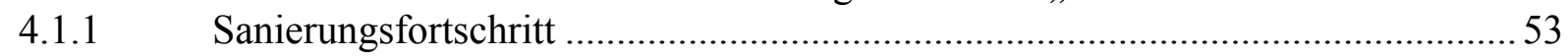

4.1.1.1 Sanierungsfortschritt zum Untersuchungszeitpunkt 08.02.2000.........................54

4.1.1.2 Sanierungsfortschritt zum Untersuchungszeitpunkt 18.12.2001 ........................55

4.1.1.3 Sanierungsfortschritt zum Untersuchungszeitpunkt 06.05.2002 .......................56

4.1.1.4 Sanierungsfortschritt zum Untersuchungszeitpunkt 23.01.2003 .........................58

4.1.1.5 Sanierungsfortschritt zum Untersuchungszeitpunkt 15.06.2004.........................59

4.1.1.6 Sanierungsfortschritt zum Untersuchungszeitpunkt 02.02.2005 .......................60

4.1.1.7 Sanierungsfortschritt zum Untersuchungszeitpunkt 27.07.2005 .......................61

4.1.1.8 Sanierungsfortschritt zum Untersuchungszeitpunkt 12.12.2005.........................6. 62

4.1.1.9 Sanierungsfortschritt zum Untersuchungszeitpunkt 06.04.2006.......................63

4.1.1.10 Sanierungsfortschritt zum Untersuchungszeitpunkt 19.10.2006.............................64

4.1.1.11 Sanierungsfortschritt zum Untersuchungszeitpunkt 17.04.2007 ........................66

4.1.1.12 Sanierungsfortschritt zum Untersuchungszeitpunkt 22.10.2007 ........................67

4.1.1.13 Sanierungsfortschritt zum Untersuchungszeitpunkt 09.05.2008.........................68

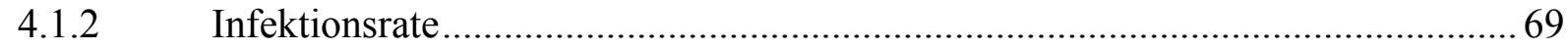

4.1.2.1 Prozentualer Anteil von Svanovir- und IDEXX-Reagenten in der

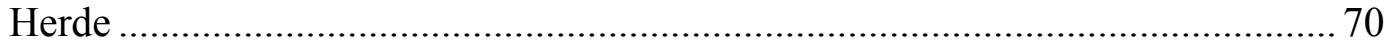

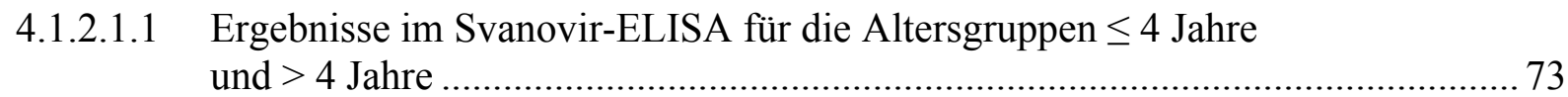

4.1.2.1.2 Ergebnisse im IDEXX-ELISA für die Altersgruppen $\leq 4$ Jahre und

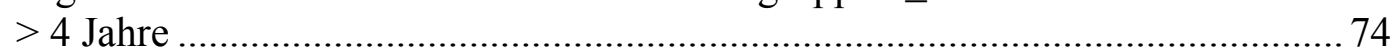

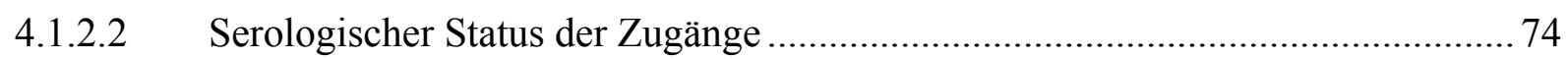

4.1.2.2.1 Zugänge, die Svanovir-Reagenten waren und später im IDEXX-

ELISA reagiert haben .......................................................................... 77

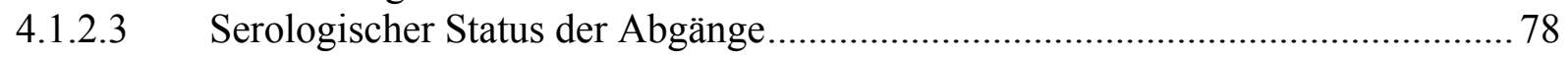

4.1.3 Ermittlung des Infektionsdrucks in verschiedenen Altersgruppen........................ 81

4.1.3.1 Auf der Basis der Svanovir-ELISA-Messwerte errechnete

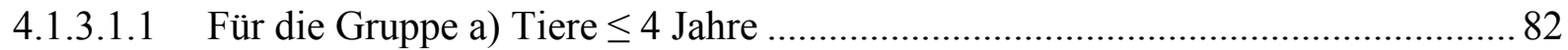

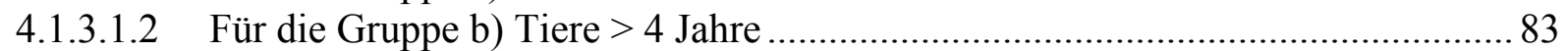

4.1.3.1.3 Mittelwerte des Svanovir-ELISAs für die gesamte Herde ................................... 84

4.1.3.2 Auf Basis der IDEXX-ELISA-Messwerte errechnete Mittelwerte ....................... 85

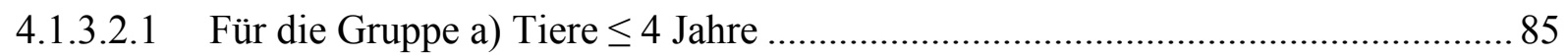

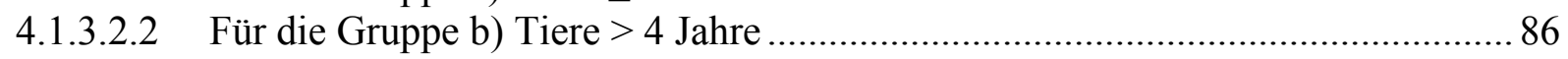

4.1.3.2.3 Mittelwerte im IDEXX-ELISA für die gesamte Herde..................................... 87

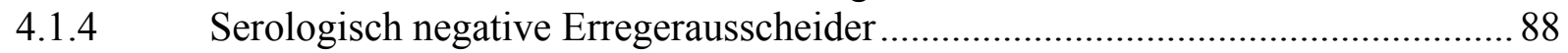

4.2 Vergleich und Eignung der beiden eingesetzten ELISA-

Testsysteme für die Paratuberkulosediagnostik ................................................ 92

4.2.1 Korrelation von IDEXX- und Svanovir-ELISA zu definierten

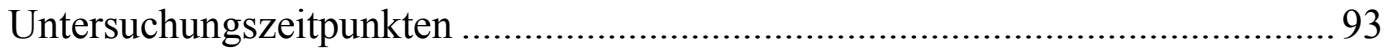

4.2.2 Zeitpunkt des erstmaligen Auftretens von Antikörpern bei

Reagenten im Svanovir- und im IDEXX-ELISA ............................................. 95

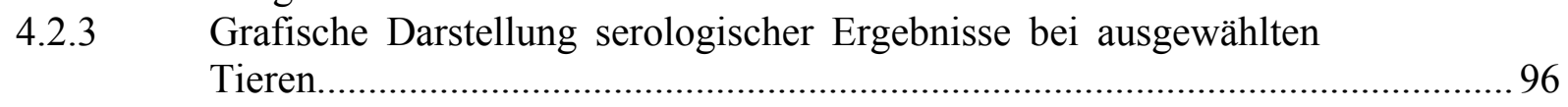

4.2.4 Bestimmung der Korrelation von IDEXX- und Svanovir-ELISA
über den gesamten Untersuchungszeitraum mit Hilfe des GLMM................... 110 
Mycobacterium avium subspecies paratuberculosis (MAP) ruft bei domestizierten und Wildwiederkäuern eine chronisch granulomatöse Enteritis hervor. Von der Infektion betroffen sind vor allem Neugeborene und Jungtiere, die sich durch die Aufnahme von kontaminierter Milch, Futter oder Wasser mit dem Erreger infizieren. Die Ansteckung findet im Alter bis zu einem Jahr statt, vor allem durch kolostrale Milch. Die klinischen Erscheinungen treten dagegen erst im Alter von 2-5 Jahren auf (109). In akuten Fällen können jedoch auch Tiere unter 12 Monaten klinische Anzeichen aufweisen. Der Erreger wird durch Kot (31), Milch (59), Blut (37, 41) und Sperma (108) ausgeschieden. Die Krankheit verläuft mit unstillbarem Durchfall und anschließendem Gewichts- und Leistungsverlust. Im Endstadium der Erkrankung sind die Tiere stark abgemagert und verenden. Betroffen sind vor allem das Ileum sowie angrenzende Darmabschnitte und Darmlymphknoten (150). Seit der genauen Beschreibung des Krankheitsbildes beim Rind vor über einhundert Jahren besteht der Verdacht einer Verbindung zur Morbus Crohn des Menschen, einer chronisch-granulomatösen Ileocolitis, unter welcher die Patienten lebenslang leiden (29).

Da vorliegende diagnostische Verfahren weder eine ausreichende Sensitivität noch Spezifität zum Nachweis aller infizierten Rinder besitzen, fordert McCaughan, dass nicht nur klinisch kranke und die mittels diagnostischer Tests als positiv ausgewiesenen Rinder gemerzt werden, sondern dass auch das Management der betroffenen Betriebe verändert wird, um die Ausbreitung der Erkrankung in infizierten Beständen zu verringern (117). Die Bekämpfung der Paratuberkulose des Rindes erfolgt auf zwei Ebenen: einerseits müssen bereits infizierte Bestände saniert, andererseits muss ein Einschleppen der Krankheit in gesunde Betriebe verhindert werden (170). Die betroffenen Herden unterliegen enormen wirtschaftlichen Verlusten. Dazu gehören außer direkten Schäden durch Tod der infizierten Tiere auch indirekte Einbußen wegen Rückgang der Milchleistung, Mast- oder Fertilitätsproblemen und Nachlassen der Widerstandsfähigkeit gegenüber anderen Infektionen $(95,165)$.

Ziel dieser Arbeit ist es, anhand von serologischen Kontrolluntersuchungen und Abschaffung der serologisch IDEXX-ELISA positiven Tiere festzustellen, ob es möglich wäre, den Infektionsdruck im Betrieb zu senken und Wege zu finden, die Betriebe allmählich zu sanieren. 
Das klinische und pathologisch-anatomische Bild der Paratuberkulose ist seit Mitte des 19. Jahrhunderts als chronische Enteritis mit ausgeprägten Veränderungen der Darmschleimhaut bekannt (32). Paratuberkulose wurde erstmals im Jahre 1895 von Johne und Frothingham deutlich beschrieben. Sie bezeichneten es als eine "besondere oder als eine eigentümliche" Form von Tuberkulose beim Rind. Die Krankheit verlief bei Rindern mit chronischer Enteritis und wellenförmiger Verdickung der Darmschleimhaut. Mehrere Präparate einer sechsjährigen Kuh wurden vom Tierarzt Harms aus Jever zur Untersuchung auf Tuberkulose an das pathologische Institut der Tierärztlichen Hochschule in Dresden geschickt. In den histologischen Präparaten der verdickten Dünndarmschleimhaut fanden sich massenhaft säurefeste Stäbchen. Auch Robert Koch, dem die Präparate zur Begutachtung vorgelegt wurden, identifizierte die Erreger als Tuberkelbazillen. Im Jahre 1906 gelang es Bang trotz Verwendung zahlreicher Nährmedien nicht, den Erreger anzuzüchten (6). Er hatte festgestellt, dass es sich bei diesen Erregern um eine besondere Art von Tuberkelbazillen handelte. Daher schlug er vor, die Erkrankung als „Enteritis chronica bovis pseudotuberculosa“ zu bezeichnen. Bald darauf wurde der Name Paratuberkulose geprägt, der Erreger kulturell angezüchtet, charakterisiert und experimentell als Krankheitsursache identifiziert (116, 210, 211).

Im Jahre 1913 beschrieb Dalziel Gemeinsamkeiten zwischen der Paratuberkulose des Rindes und Morbus Crohn des Menschen. Damit warf er erstmals die auch heute noch nicht geklärte Frage nach einem möglichen ätiologischen Zusammenhang beider Erkrankungen auf. Solche Gemeinsamkeiten beschrieb auch Crohn. Er bestätigte, dass die Paratuberkulose ein ähnliches Krankheitsbild zeigt wie Morbus Crohn beim Menschen (49). Die Diskussion über eine gemeinsame Ätiologie von Paratuberkulose und Morbus Crohn beim Menschen hält bis heute an.

\section{Morbus Crohn}

Die Diskussion möglicher Zusammenhänge zwischen Morbus Crohn und MAP wurde in jüngster Zeit erneut entfacht, nachdem Untersuchungen an pasteurisierter Milch gezeigt hatten, dass MAP durch das Kurzzeit-Pasteurisierungsverfahren nicht mit Sicherheit abgetötet werden kann. 
So wurden beispielsweise Proben von an Morbus Crohn erkrankten Patienten untersucht. Insgesamt wurden 48 Proben mit Hilfe der In-Situ-Hybridisation (ISH) untersucht. Die Untersuchungen zeigten, dass von 48 Proben 35 Proben positiv waren. Die Untersuchung der gleichen 48 Proben mit Hilfe einer IS 900-PCR fiel negativ aus. Die Forscher vermuten, dass eine DNS-Fragmentierung durch die Paraffine während der Einbettung Ursache für das negative Testergebnis war. Die Versuche, in den Gewebeproben Erreger der Paratuberkulose mit Hilfe der Ziehl-Neelsen-Färbung mikroskopisch sichtbar zu machen, blieben erfolglos. Auch die Untersuchungen von Van Kruiningen mit Hilfe der IS 900-PCR hatten keine positive Ergebnisse gezeigt (212). Es ist möglich, dass die Infektion durch solche MAP-Erreger verursacht wird, die eine beschädigte Zellwand besitzen (Cell-Wall Deficient (CWD)). Dies könnte der Grund sein, dass keine säurefesten Bakterien mit der Ziehl-Neelsen Färbung festgestellt werden konnten (175). Berichte darüber, dass CWD-Formen von MAP auch Verursacher der Morbus Crohn sein können, sind widersprüchlich. Dies könnte aber an den heterogenen Erscheinungsformen der Morbus Crohn liegen, weil nur bei 50\% der Patienten die granulomatöse Form der Morbus Crohn auftritt. Um CWD-Formen des Erregers in entzündetem Gewebe zu entdecken, wurde die In-Situ-Hybridisierungsmethode angewendet. Es wurden insgesamt 37 Granulom-haltige Proben (15 mit Epitheloidzell-Granulomen und 22 ohne Granulome), 21 mit ulcerativer Colitis und 22 Kontrollproben untersucht. Die Untersuchungen zeigten in 6 von 15 Proben (40\%), in 1 von 22 (4,5\%) und in 2 von 21 (9,5\%) der Proben positive Ergebnisse, alle 22 Kontrollproben waren negativ. Diese Ergebnisse bestätigen, dass CWD-Formen des Erregers sehr wohl Mitverursacher der Morbus Crohn sein könnten (90).

In einer anderen Studie wurde von zwei an Morbus Crohn erkrankten Frauen Brustmilch entnommen, um MAP-Erreger zu isolieren. Die Milchproben wurden im Kulturmedium 12 Wochen bei $37^{\circ} \mathrm{C}$ inkubiert und anschließend mit Hilfe der IS 900-PCR untersucht. Die Untersuchungen ergaben, dass die Proben von beiden Frauen MAP-Erreger enthielten (139).

MAP ist in der Umwelt weit verbreitet und kommt gewöhnlich im tierischen und menschlichen Verdauungstrakt vor. Meistens verursacht MAP keine Krankheit, außer wenn der Wirt geschwächt ist. Der kombinierte Einsatz von Rifabutin und Clarithromyzin kann dazu führen, dass etwa zwei Drittel der an Morbus Crohn erkrankten Patienten allmählich genesen und geheilt werden (83).

Es wurden von an Morbus Crohn erkrankten Patienten chirurgisch Gewebeproben entnommen und formalinfixiert. Um MAP-DNS in den Proben nachzuweisen, wurde die Laser Capture Microdissection (LCP) und PCR angewendet. Von den insgesamt 15 Fällen konnte bei 6 Patienten MAP-DNS isoliert werden. Bei 12 Kontrollproben wurde keine MAP-DNS festge- 
stellt (166). In einer weiteren Untersuchung wurden wieder Gewebeproben von an Morbus Crohn erkrankten Patienten mit chirurgischen Methoden gewonnen und mit Hilfe der LCP und PCR untersucht. Es wurden insgesamt 15 Proben von an Morbus Crohn erkrankten Patienten untersucht. Aus 12 Proben wurde E. coli-DNS isoliert. Von den 10 Kontrollproben wurde nur aus einer einzigen Probe E. coli-DNS isoliert. Dies spricht dafür, dass keines der Bakterien der alleinige Verursacher der Morbus Crohn sein kann (167). Ein an Morbus Crohn erkrankter Patient wurde mit Rifabutin und Clarithromyzin behandelt und heilte aus. Ein nach zwei Jahren auftretendes Rezidiv wurde erneut erfolgreich mit Rifabutin und Clarithromyzin therapiert. Der MAP-Erreger konnte jedoch weder mikroskopisch noch mittels Kulturmethode isoliert werden (82). Von einer an Morbus Crohn leidenden Patientin wurden Blutproben entnommen und mittels PCR (IS 900) untersucht. Die Untersuchungen ergaben, dass MAPErreger aus dem Blut des Patienten isoliert werden konnten. Nach sorgfältiger Auswahl der entsprechenden Antibiotika wurde der Patient behandelt. Nach drei Wochen Therapie waren alle Symptome (Bauchschmerzen, Durchfall, Ermüdungserscheinungen) verschwunden. Nach sechs Monaten wurde der Patient noch einmal untersucht, die Untersuchungen ergaben eine vollständige Genesung. Dieser Fall weist darauf hin, dass der MAP-Erreger an der Entwicklung von Morbus Crohn beteiligt ist (22).

\section{3}

\section{Ätiologie}

\subsection{1}

\section{Morphologische Eigenschaften des Erregers}

Die Paratuberkulose des Rindes ist eine chronisch verlaufende, unheilbare Infektionskrankheit, die durch Mycobacterium paratuberculosis (MAP) hervorgerufen wird und die sich nach mehrjähriger Inkubationszeit in Form von unstillbarem Durchfall manifestiert. MAP zählt zum Mycobacterium avium- Komplex (MAC), welcher in den letzten Jahren aufgrund der hohen Prävalenz von disseminierten Infektionen, v.a. bei an AIDS erkrankten Patienten, groBe Bedeutung erlangt hat (163).

Die Gattung Mycobacterium (M.), welche zur Familie der Mycobacteriaceae und zur Ordnung der Actinomycetales gehört, enthält außer MAP verschiedene andere pathogene Erreger. M. tuberculosis und M. bovis rufen bei Menschen und Tieren die Tuberkulose hervor. M. leprae ist der Erreger der Lepra bei Menschen. MAP ist ein 1-1,5 $\mu \mathrm{m}$ langes und 0,3-0,5 $\mu \mathrm{m}$ breites aerobes unbewegliches Stäbchen, dessen Charakteristikum die Säure- und AlkoholFestigkeit ist. Das Bakterium ist auch gegenüber Laugen stabil. Die nur schwach positive Anfärbbarkeit nach Gram ist auf den besonderen Aufbau der Zellwände zurückzuführen. Diese enthalten hohe Anteile an Lipiden und wachsartigen Verbindungen sowie chloroformlösliche 
Mycolsäuren aus langen verzweigten Ketten von 60-90 C-Atomen. Die wenig permeable Zellwand besteht aus einer äußeren Peptidoglycanschicht, gefolgt von einer Schicht mit langkettigen Fettsäuren, die mit Arabinogalactan gekoppelt sind. Nach außen wird die Zellwand durch eine Schicht von Peptidoglycolipiden abgeschlossen (33). Lipoarabinomannan (LAM) ist in der Zellwand verankert und stellt einen löslichen, immunmodularischen Zellwandbestandteil dar. So kann durch LAM die Aufnahme der Erreger über Mannose-Rezeptoren von Makrophagen vermittelt werden, eine Aktivierung der Zellen erfolgt dabei aber nicht (17).

M. paratuberculosis steht in enger Beziehung zu dem M. avium-M. intracellulare (MAI)Komplex, da einige Stämme dieses Komplexes ebenfalls Mycobactin-abhängig sind und MAI sowie M. paratuberculosis mehr als 90\% homologe DNS aufweisen (26). Mittels der ,restriction fragment lenght polymorphism“-Methode (RFLP) fand Chiodini eine 78-98\%-ige Übereinstimmung des rRNA-Genbereiches zwischen dem MAI-Komplex und M. paratuberculosis, jedoch in unmittelbarer Nähe des 5 rRNA Gens auch einen Bereich, welcher einen Polymorphismus offenbart und somit die Differenzierung von $M$. paratuberculosis ermöglicht (26). Der Autor wies in dieser Studie die genetische Homogenität aller M. paratuberculosisStämme nach, unabhängig von Entnahmequelle (Rind, Schaf, Ziege, Mensch, Primat) und geografischer Herkunft. Er schlug unter Beibehaltung von M. paratuberculosis als eigene Art eine Erweiterung der Bezeichnung des MAI-Komplexes auf MAIP-Komplex vor (M. avium, M. intracellulare, M. paratuberculosis). Besondere Charakteristika von MAP sind die Stimulation des Bakterien-Stoffwechsels durch Zugabe von Pyruvat sowie das mycobactinabhängige Wachstum auf Eidotternährböden. Für ein optimales Wachstum ist sogleich ein Zusatz von $1 \mu \mathrm{g}$ Mycobactin pro ml Nährmedium erforderlich (107).

Mycobactine sind zellwandständige Siderophore, die der Stoffgruppe der HydroxamatVerbindungen angehören. Sie dienen den Mykobakterien zur essentiellen Bereitstellung von Eisen (68). Die Abhängigkeit des MAP von diesem wachstumsfördernden Eisenchelatbildner dient als wichtigstes Merkmal zur Identifizierung des Erregers bei kulturellen Untersuchungen von Isolaten aus Kot- und Organproben.

Auf molekularer Ebene dient die von Green entdeckte Insertionssequenz 900 (IS 900) von $1451 \mathrm{bp}$ als Unterscheidungsmerkmal, von der im MAP-Genom 15-20 Kopien vorhanden sind. Bisher konnte sie bei allen untersuchten Referenzstämmen nachgewiesen werden, jedoch nie bei anderen Mycobakterienspezies oder verwandten Gattungen wie Streptomyces und Nocardia $(1,64,75,102,135,215)$. 
MAP-Erreger werden anhand ihres Wachstums und der molekularen Charakterisierung der IS 900 mit Hilfe der RFLP in folgende drei Gruppen unterteilt: Sheep (Typ I), cattle (Typ II) und intermediate (Typ III), (149).

\subsection{2}

\section{Tenazität des Erregers}

MAP ist ein sehr umwelt beständiger, resistenter Mikroorganismus, der lange Zeit in der Umwelt überleben kann. Die Überlebensdauer ist bei niedrigen Temperaturen sowie bei ausreichender Feuchtigkeit, fehlender Sonneneinstrahlung und niedrigen $\mathrm{pH}-$ Werten im Boden besonders lang. Das Bakterium überlebte eine Lagerung bei $-14{ }^{\circ} \mathrm{C}$ mindestens ein Jahr. Je länger die Überlebensdauer des Mikroorganismus in der Umwelt währt, desto höher ist die Wahrscheinlichkeit einer Infektion von Weidetieren (98). Die Untersuchungen von Rosenberger zeigten, dass es möglich war, MAP noch nach 11 Monaten aus Weidekot infizierter Tiere zu isolieren (165). Damit besteht die Möglichkeit, dass die Tiere sich beim Weideaustrieb im folgenden Jahr über kontaminierte Flächen infizieren. In einer aus 90\% Urin und 10\% Kot bestehenden Masse konnten nach 30 Tagen keine lebensfähigen MAP-Erreger mehr nachgewiesen werden. Lovell konnte den Erreger aus infiziertem Kot noch nach 246 Tagen isolieren und aus fließendem Gewässer nach 163 Tagen (114). Die Untersuchungen von Larsen zeigten, dass MAP in Leitungswasser, dessen $\mathrm{pH}-$ Wert 5-8,5 betrug, noch nach 14 Monaten kultivierbar war (110). Aus stehenden Gewässern konnte er den Erreger dagegen noch nach 270 Tagen isolieren. MAP ist sehr empfindlich gegenüber Sonnenlicht. Bei direkter Sonneneinstrahlung werden die Bakterien nach 100 Stunden inaktiviert (110). MAP besitzt eine hohe Widerstandsfähigkeit gegenüber Desinfektionsmitteln wie z.B. Säuren, Laugen und quartären Ammoniumverbindungen. Bei der Aufbereitung von kontaminiertem Probenmaterial (Kotproben oder Organmaterial) zur Anzucht des MAP wird diese Eigenschaft ausgenutzt (137).

Eine Hitzebehandlung ist die am häufigsten verwendete Methode, um Milch und Milchprodukte für den menschlichen Verzehr geeignet zu machen. Nach Angaben von verschiedenen Forschergruppen ist MAP ein sehr widerstandsfähiger Mikroorganismus, der in der Lage ist, der Pasteurisierung auch bei hohen Temperaturen zu widerstehen. Nach Angaben von Rademaker kann MAP sogar der HTST (High temperature short treatment) (15 sec. $\left.72^{\circ} \mathrm{C}\right)$ Pasteurisierung widerstehen (155). Es konnte jedoch nur eine Reduktion der Erregerkonzentration um den Faktor 7 erreicht werden. Abweichend davon konnte nach Angaben von Hammer die Reduzierung der MAP-Erregeranzahl um den Faktor 6 erreicht werden. Diese Arbeitsgruppe konnte auch einzelne Erreger entdecken, die in der Lage waren, dem Erhitzen auf $90^{\circ} \mathrm{C} \mathrm{zu}$ 
widerstehen. Gründe für diese außergewöhnlich hohe Resistenz werden in einer Klumpenbildung der Zellen vermutet oder auch im intrazellulären Parasitismus des Erregers (80).

Eine Forschergruppe aus Australien hat versucht herauszufinden, ob die Milch, die mit üblichen Methoden pasteurisiert in den Einzelhandel gelangt, MAP frei ist. Für die Studie wurde Milch in größeren Mengen verwendet, in die der Erreger künstlich inokuliert wurde. Die kontaminierte Milch wurde homogenisiert und mit einem industriellen Pasteurisator $(3000 \mathrm{~L} / \mathrm{h})$ pasteurisiert. Der Pasteurisierungsprozess wurde bei $72{ }^{\circ} \mathrm{C}$ bis $78{ }^{\circ} \mathrm{C}, 15$ bis 25 sec. lang durchgeführt. Nach der Pasteurisierung wurde festgestellt, dass die Pasteurisierung unter diesen Bedingungen in $85 \%$ der Proben mehr als $6 \log _{10}$ der Erreger eliminiert hatte, und in den restlichen Proben mehr als $4 \log _{10}(119)$.

Es ist bekannt, dass UV-Licht in der Lage ist, Mikroorganismen unschädlich zu machen. Aus diesem Grunde haben Wissenschaftler aus Großbritannien versucht, UV-Licht als alternative Methode zur herkömmlichen Pasteurisierung zu etablieren. Die Untersuchungen zeigten jedoch, dass UV-Licht nicht in der Lage war, die Erreger-Anzahl in der Milch signifikant zu senken (3).

Infizierte Milchkühe scheiden den MAP-Erreger vor allem mit Kot, Milch und Kolostrum aus. Die neugeborenen Kälber infizieren sich hauptsächlich in den ersten Lebenstagen, wenn sie mit dem Kolostrum erkrankter Tiere gefüttert werden. Außerdem kann die Übertragung der Infektion stattfinden, wenn das Kolostrum mit erregerhaltigem Kot kontaminiert ist. Um die Weitergabe der Infektion an Neugeborene zu verringern, wurde versucht, das Kolostrum durch Pasteurisierung zu dekontaminieren. Einige Forscher (191) berichten, dass Kolostrum, das mit $105 \mathrm{cfu} / \mathrm{ml}$ (colony forming unit) MAP-Erreger infiziert wurde, mit der HTSTPasteurisierung (15 sec. $71,7^{\circ} \mathrm{C}$ ) erfolgreich dekontaminiert werden konnte. Nachteil der HTST-Pasteurisierung ist jedoch, dass die Viskosität des Kolostrums steigt und wertvolle Immunoglobuline (Ig) denaturiert werden, welche der neugeborene Organismus dringend braucht. Diese Nachteile kann man überwinden, indem das Kolostrum bei niedrigen Temperaturen, aber über lange Zeit erhitzt wird. Eine Hitzebehandlung über einen Zeitraum von $60 \mathrm{~min}$ bei $60^{\circ} \mathrm{C}$ sollte ausreichend sein, um den MAP-Erreger zu zerstören oder ausreichend zu reduzieren. Um diese Aussage bestätigen zu können, müssen jedoch noch weitere Studien durchgeführt werden (72). 
Die Entwicklung der Paratuberkulose verläuft in vier Stufen: I) Stille Infektion II) Subklinisches Stadium III) Klinische Erscheinung IV) Fortgeschrittene klinische Phase. Von der Paratuberkulose betroffene Kälber und Jungtiere sind im Anfangsstadium schwer zu diagnostizieren. Die Futteraufnahme, Gewichtszuwachs und äußere Erscheinung sind mit denen gesunder Tiere identisch. In diesem Stadium kann MAP entweder histologisch in Gewebe detektiert oder anhand einer Gewebekultur aus Darmgewebe bzw. den Lymphknoten isoliert werden. Im subklinischen Stadium sind bei den Tieren keine sichtbaren Zeichen wie Durchfall zu bemerken. Jedoch kann bei diesen Tieren eine zelluläre Immunantwort sowie Antikörperreaktion gemessen werden. Viele dieser Tiere sind nach Fäkalkultur negativ, weil in diesem Stadium der MAP-Erreger in nur geringen Mengen ausgeschieden wird. Bis zum Auftreten klinischer Anzeichen kann es 2 bis 10 Jahre dauern. In diesem Zeitraum verlieren die Tiere allmählich an Gewicht und Produktivität trotz gleich bleibender Futteraufnahme. Im Laufe der Zeit wird der Kot dünnflüssig und ist von intermittierendem Durchfall begleitet. Die Milchleistung lässt nach, und die Euterhaut sowie die Schleimhäute werden zunehmend blass. Ein rauhes, glanzloses Haarkleid sowie trockene Haut sind weitere Symptome der Erkrankung. Innerhalb von 3 bis 4 Monaten geht die Krankheit ins progressive klinische Stadium mit permanentem unstillbarem Durchfall über, der bis zum Tod des Tieres andauert. Der mit Gasbläschen durchsetzte, dunkelbraune Kot wird mit fortschreitender Erkrankung immer dünnflüssiger (223).

Bei weitgehend ungestörtem Allgemeinbefinden magern die Tiere ab, wobei ihre Futteraufnahme unverändert gut bleibt. Bei einigen der erkrankten Rinder ist intermittierendes Fieber mit Temperaturen bis $41^{\circ} \mathrm{C}$ zu beobachten. Die einzelnen Fieberphasen dauern 4-6 Tage und werden von reduzierter Futter- und Wasseraufnahme begleitet. In der Endphase der Erkrankung führen Appetitlosigkeit, völlige Abmagerung und Entkräftung, verbunden mit Blutbeimengungen im Kot und ventralem Ödem, zum Tod des Tieres (31) Die zelluläre Immunantwort ist bei durch Mykobakterien hervorgerufenen Infektionen sehr wichtig. Für die Immunitätsentwicklung gegen fakultativ intrazelluläre Bakterien treten gewöhnlich T-Lymphozyten und Makrophagen gemeinsam in Aktion (79). T-Lymphozyten rekrutieren mononukleäre Phagozyten, fügen sie für die Bildung der Granulome zusammen und aktivieren Makrophagen für die bakterizide Tätigkeit. Die zelluläre Immunität ermöglicht dem Wirt, das Bakterium zu zerstören (51). 
Die Granulombildung und Aktivierung der Makrophagen mit Hilfe Antigen-stimulierter TZellen sind für eine effektive zell-mediierte Immunantwort notwendig. Die humorale Immunantwort hat bei Paratuberkulose keine Schutzwirkung (23, 52, 63). Der Titer der Antikörper, die gegen MAP gerichtet sind, steht in direktem Zusammenhang mit der Erregermenge. Die Ausbildung der humoralen Immunantwort deutet auf eine verstärkte bakterielle Proliferation und verringerte zellmediierte Immunantwort (ZMI) hin, so dass ein antiproportionaler Zusammenhang zwischen humoraler und zellulärer Immunantwort besteht.

\subsubsection{Pathologie}

Man kann zwei pathohistologische Formen der Infektion mit MAP unterscheiden: Die multibacilläre „lepromatose“ Form zeichnet sich durch eine erhebliche Anzahl infizierter Makrophagen im Darmgewebe und eine hohe Konzentration von Serumantikörpern aus. Die „pauzibazilläre“ Form wird dagegen durch wenige „tuberkuloide“ Läsionen, eine niedrige Serumantikörper-Konzentration und eine starke zelluläre Immunantwort charakterisiert (31, $34,152,188,202)$.

Im subklinischen Stadium ist eine zellmediierte Immunantwort nachweisbar, die nach intrazellulärer Vermehrung der Erreger und ihrer Freisetzung aus den Makrophagen mit einem ansteigenden Serumantikörpertiter in die Entwicklung der „multibazillären“ Form mit klinischer Ausprägung übergeht (31). Nach oraler Aufnahme gelangen die Erreger der Paratuberkulose im Bereich der Peyer'schen Platten durch das Oberflächenepithel in die Mukosa des Gastrointestinaltraktes $(31,133)$.

Nach der Aufnahme durch Makrophagen werden die Erreger nicht zerstört, sondern können sich innerhalb dieser Zellen ungehemmt vermehren, wodurch die Makrophagen schließlich zugrunde gehen und die Erreger freisetzen. Diese werden entweder ausgeschieden oder erneut phagozytiert, was zu einer starken Ansammlung bakterienhaltiger Makrophagen im Bereich der Darmzotten und später in tieferen Schichten der Propria führt (77).

Etliche Monate nach der Infektion mit MAP werden die Erreger aus den Makrophagen freigesetzt und regen die Produktion von Antikörpern an. Gleichzeitig wird die Nachweisbarkeit der ZMI geringer. Einige Forscher vertreten aufgrund ihrer Untersuchungen die Ansicht, dass ein Abfall der ZMI, speziell ein Absinken der $\gamma$-IFN-Konzentration, mit der Entwicklung der klinischen Ausprägung der Paratuberkulose einhergeht. Aus einer Erhöhung der Expression von $\gamma$-IFN könnte sich deshalb ein therapeutischer Ansatz ableiten. Die produzierten Antikörper vom Typ IgG und IgM sind nicht in der Lage, die Infektion einzudämmen. Tiere mit klini- 
scher Ausprägung der multibacillären Form weisen eher hohe Antikörperspiegel auf (151, 202, 225).

Im weiteren Verlauf folgt die paratuberkulöse Entzündung des Darms und der Darmlymphknoten. Die Bakterien gelangen über die Lymphgefäße zu den Gekröselymphknoten, die dann vergrößert und mit multiplen Granulationsprozessen durchsetzt sind. Im fortgeschrittenen Stadium der Erkrankung ist vor allem bei Rindern unstillbarer Durchfall das auffälligste klinische Symptom. Dies resultiert aus einer Überempfindlichkeitsreaktion gegenüber dem Mykobakterien-Antigen. Sie wird verursacht durch die Freisetzung von Histamin aus Mastzellen im infizierten Darmabschnitt. Durch Verabreichung großer Mengen Antihistaminika gelang es, die Schwere der klinischen Symptome bei experimentell infizierten Rindern abzumildern (125). Diese pathogenetischen Mechanismen werden durch mehrere Untersuchungen $(13,18)$ gestützt, bei denen im Bereich der Schleimhautveränderungen Mastzellen nachgewiesen werden konnten, in denen Histamin in Tröpfchen gespeichert war. Histamin führt zu entzündlichen Veränderungen des Darmgewebes mit Erweiterung der Gefäße, Erhöhung der Gefäßpermeabilität und Aktivierung der glatten Muskulatur der Darmwand. Die Folgen sind gesteigerte Darmmotilität und starker Proteinverlust. Als Folge des unstillbaren Durchfalls wird die Nährstoffaufnahme allgemein reduziert, und der verringerten Aufnahme von Aminosäuren steht eine gesteigerte Abgabe von Proteinen gegenüber. Die hieraus resultierende negative Stickstoffbilanz führt zum Abbau des Muskeleiweißes als Kompensationsversuch. Der Muskelschwund ist die sichtbare Folge $(147,148)$.

Der Beginn der klinischen Erkrankung steht oft im Zusammenhang mit der Abkalbung und Laktation. Einige Hormone, die in Trächtigkeit und Laktation involviert sind, wirken auf die Phagozytose von MAP und das intrazelluläre Wachstum der Erreger in Monozyten ein (36, 66, 92). Physiologische Prolaktin-Konzentrationen von $15-50 \mathrm{ng} / \mathrm{ml}$ und erhöhte Konzentrationen von 20-200 ng/ml hatten über eine Inkubationsperiode von 12 Tagen keinen Einfluss auf das intrazelluläre Wachstum der Erreger. Wurden jedoch die infizierten Monozyten ab dem fünften Tag der Inkubation dem Einfluss des Prolaktins entzogen, stieg das Wachstum der Erreger signifikant an. Ein inhibierender Effekt konnte mit keiner Prolaktin-Konzentration nachgewiesen werden, jedoch könnte eine prolongierte Exposition in vivo einer Vermehrung von MAP entgegenwirken.

Beim Übergang von der subklinischen paucibacillären Ausprägung der Paratuberkulose in die multibacilläre klinische Form beginnen die Tiere damit, massiv Erreger auszuscheiden und infizieren somit unmittelbar ihre Nachkommen $(33,71)$. 
Die Paratuberkulose ist eine weltweit verbreitete Infektionskrankheit. In den Ländern Kanada, USA, Südamerika, Südafrika, Indien, Japan, Australien und Neuseeland tritt sie vermehrt auf (165). Auch in europäischen Ländern wie Dänemark, Deutschland, Frankreich, Norwegen, Holland, Belgien und der Schweiz hat sie große Bedeutung erlangt (31). Die Krankheit ist besonders in Regionen weit verbreitet, in denen der $\mathrm{pH}-\mathrm{Wert}$ der Böden niedrig ist. In sauren Böden können die MAP-Erreger lange Zeit überleben. In Großbritannien, den Niederlanden, Frankreich, Italien und den USA tritt diese Krankheit in Gebieten mit sauren Bodenverhältnissen auffallend gehäuft auf.

In vielen Ländern werden daher diagnostische Untersuchungen auf Paratuberkulose durchgeführt, um die Herdenprävalenz festzustellen. Einige Länder führen auch bereits Bekämpfungsprogramme durch. $(15,136)$.

Um die Paratuberkuloseprävalenz in Südkorea feststellen zu können, wurden dort landesweite Untersuchungen durchgeführt. Aus 8 Landkreisen wurden insgesamt 1056 Blutproben aus 448 Fleischrinderbeständen und 1105 Blutproben aus 219 Milchrinderbeständen serologisch mittels ELISA untersucht. Die Untersuchungen zeigten, eine landesweite Prävalenz von 7,1\% (146).

Im Jahre 2002 wurden in Kanada insgesamt 1799 Blutproben aus 66 Herden serologisch (ELISA) auf Paratuberkulose untersucht. Die Untersuchungen zeigten, dass die Prävalenz der Paratuberkulose in Rinderbeständen 0,27 bis 2,5\% beträgt (218). Im Jahre 2005 wurden in Kanada insgesamt 1530 Blutproben aus 51 Herden serologisch auf Paratuberkulose untersucht. Vergleichbare Untersuchungen aus den Jahren 2005 bestätigen eine Prävalenz von 2,7\% (213). Im Jahre 2007 wurden in Kanada insgesamt 2996 Blutproben aus 100 Herden serologisch auf Paratuberkulose untersucht. Die Untersuchungen zeigten, dass die Prävalenz der Paratuberkulose in kanadischen Rinderbeständen mittlerweile auf 7,9\% angestiegen ist (174).

Im Jahre 1994 wurden in Wisconsin (USA) insgesamt 4990 Blutproben aus 158 Rinderherden serologisch auf Paratuberkulose untersucht. Die Untersuchungen ergaben eine Herdenprävalenz von 50\%, davon waren 7,29\% der Gesamttierzahl betroffen (44). Im Jahre 2003 wurden in Alabama (USA) insgesamt 2073 Blutproben aus 79 Rinderherden serologisch auf Paratuberkulose untersucht. Die Untersuchungen zeigten, dass die Prävalenz der Paratuberkulose in Rinderherden aus Alabama 53,5\% beträgt, davon waren 8,0\% der Einzeltiere betroffen (87). 
Die Untersuchungen des National Animal Health Monitoring Systems (5) in den USA im Jahre 2007 zeigten, dass 68,1\% der Milchviehbestände von Paratuberkulose betroffen waren. Die Paratuberkulose ist auch in Argentinien weit verbreitet. Betroffen sind dort sowohl Milch- als auch Fleischrinder (145).

Die Paratuberkulose kommt auch in Island vor. Die ersten Fälle der Paratuberkulose sind in Island eingetreten, als man im Jahre 1933 zwanzig Karakul-Schafe aus Deutschland importiert hatte. Innerhalb von 16 Jahren war die Paratuberkulose in Island so weit verbreitet, dass sie landwirtschaftliche Betriebe in den Ruin führte. Dabei muss besonders berücksichtigt werden, dass die Schafhaltung in Island der wichtigste Zweig der Agrarindustrie war. Die ersten klinischen Fälle der Paratuberkulose beim Schaf wurden im Jahre 1938 bestätigt, bei Rindern dagegen erst im Jahre 1944. Die Paratuberkulose wurde somit in Island von Schafen auf die Rinder übertragen (69).

Die Paratuberkulose war seit den 1960-er Jahren in norwegischen Ziegenbeständen endemisch verbreitet. Bei Rindern und Schafen kam sie nur sporadisch vor. Im Jahre 1996 wurde ein landesweites Kontroll- und Überwachungsprogramm ins Leben gerufen. Am Anfang wurden nur importierte Tiere und deren Kontaktherden untersucht. Es wurden insgesamt 1403 Tiere aus 134 Herden serologisch im ELISA untersucht. Die Untersuchungen zeigten, dass 11\% der Rinder serologisch positiv waren. Im Jahre 1998 und 1999 wurden die Untersuchungen erweitert und auch einheimische Rinder untersucht, die keinen Kontakt zu den importierten Tieren gehabt hatten. Die Untersuchungen zeigten, dass 8\% dieser Rinder serologisch positiv waren (88). Von 1996 bis 1999 wurden in Norwegen insgesamt 9456 Blutseren von Rindern aus 754 Herden serologisch mittels ELISA auf Paratuberkulose untersucht. Es wurde festgestellt, dass 728 Tiere (7,7\%) hohe Antikörpertiter hatten (208).

Die Paratuberkulose ist schon lange in dänischen Milchkuhherden verbreitet. Um genaue Angaben über die Herdenprävalenz des Landes machen zu können, wurde die Tankmilch von 900 Milchbeständen (7,5\% der dänischen Milchbestände) aus 6 verschieden Regionen anhand der ELISA-Technik untersucht. Es wurde festgestellt, dass von den untersuchten Milchbeständen ungefähr 70\% infiziert waren (140).

Die Paratuberkulose ist auch in Holland weit verbreitet. Es wurden insgesamt 378 Herden (15822 Tiere, die mindestens 3 Jahre waren) serologisch mit ELISA untersucht. Die Untersuchungen zeigten, dass von den untersuchten 378 Herden 55\% der Betriebe zwischen 1 und 3 serologisch positive Tiere hatten (136).

Um den Verbreitungsgrad der Paratuberkulose bei Milchkühen festzustellen, wurden in der Schweiz Tankmilchuntersuchungen mit Hilfe der PCR (IS 900) durchgeführt. Insgesamt wur- 
den 1384 Tankmilchproben untersucht, davon waren 273 Proben (19,7\%) in der PCR positiv. Es wurde festgestellt, dass die Seroprävalenz in Milchbeständen regional großen Schwankungen $(1,7-49,2 \%)$ unterlag (46).

Um die Verbreitung der Paratuberkulose in Österreich feststellen zu können, wurden Schlachttier-basierte Untersuchungen durchgeführt. Insgesamt wurden 756 Rinder serologisch im ELISA untersucht. Es wurde festgestellt, dass 19\% der untersuchten Rinder (144 Tiere) serologisch positiv waren (60).

In Deutschland ist Paratuberkulose eine meldepflichtige Tierseuche, die v.a. in Norddeutschland vorkommt. Sie ist in Niedersachsen besonders weit verbreitet. Grenzüberschreitende Tierverkäufe zwischen verschiedenen Ländern trugen in den letzten Jahren besonders zur schnellen Verbreitung der Krankheit bei. 2004 wurden in Mecklenburg-Vorpommern (Deutschland) aus 59 Betrieben (durchschnittlicher Kuhbestand von 334 Tieren) stichprobenartig 2997 Blutproben entnommen und auf Paratuberkulose untersucht. Die Untersuchungen, die mittels Svanovir-ELISA durchgeführt wurden, ergaben eine Herdenprävalenz von 12,2\%. Fünfzig der 59 untersuchten Betriebe wiesen Antikörper auf (78).

\subsection{2}

\section{Wirtsspektrum und Empfänglichkeit}

Die Paratuberkulose ist eine Erkrankung der Wiederkäuer. Betroffen sind vor allem Rinder, Schafe und Ziegen. Der Erreger konnte aber auch aus Rotwild sowie Muffelwild, Sikawild, Elchen, Bighorn-Schafen und Gnus isoliert werden (30). Auch unter Wiederkäuern zoologischer Gärten wie Kamel, Dromedar, Lama, Zebu und Yak ist die Krankheit aufgetreten (205). Wegen der niedrigen Bestandsdichte in der freien Natur wird die Krankheit unter Wildwiederkäuern kaum verbreitet und erregt deshalb keine große Aufmerksamkeit (220).

Im Jahre 2000 wurden in Kalifornien 37 erlegte Elche (Cervus elaphus nannodes) auf Paratuberkulose untersucht. Aus Gewebe und Kot der erlegten Tiere wurden Untersuchungen durchgeführt. Bei einem erwachsenen Tier wurde aus dem Ileocaecal-Lymphknoten MAPErreger kultiviert (48). Serologische und kulturelle Untersuchungen in den USA ergaben, dass der Virginiahirsch (Odocoileus virginianus) auch an Paratuberkulose erkranken kann (53, 154). Die Paratuberkulose wurde auch in Argentinien bei Rothirschen (Cervus elaphus) festgestellt (144).

Partuberkulose wurde auch bei freilaufenden Hirschen in Spanien diagnostiziert. Von einer Hirschherde mit 1000 Tieren wurden im Jahre 1997/98 acht Tiere mit Durchfallerscheinungen auf Paratuberkulose untersucht. Von acht untersuchten Tieren waren sieben positiv (115). 
Serologische ELISA-Untersuchungen in Norwegen ergaben, dass in den Populationen von Elchen, Rotwild, Rehwild und halbwilden Rentieren Antikörper gegen Paratuberkulose vorhanden sind (208).

Im Jahre 1985 wurden 16 Saiga-Antilopen aus deutschen zoologischen Gärten nach Kanada importiert. Die Untersuchungen in Deutschland hatten ergeben, dass die Tiere paratuberkulosefrei gewesen waren. Die Tiere wurden in den nachfolgenden sechs Jahren weiterhin untersucht. Histologische Untersuchungen ergaben, dass vier dieser Tiere an Paratuberkulose erkrankten (61).

Ergebnisse von ELISA- Tests, Anzuchtkulturen und PCR-Untersuchungen in den USA ergaben, dass die Bison-Herden ebenfalls von Paratuberkulose betroffen sind (19).

Bakteriologische und PCR-Untersuchungen ergaben dasselbe Bild für Büffel in Indien (181). Unter experimentellen Bedingungen können sich auch monogastrische Tiere infizieren. So gelang es, nach oraler Verabreichung von MAP in größeren Mengen, sowohl Pferde als auch Schweine zu infizieren (111). Bei diesen Tieren kommt es zur Vermehrung des Erregers, eine klinische Symptomatik der Erkrankung ist jedoch nicht festzustellen (31).

Es ist bekannt, dass Kaninchen mögliche Wirte und Überträger der MAP-Erreger sein könnten. In 2 Landkreisen war MAP sowohl aus Kaninchen als auch aus Rindern isoliert worden. Um herauszufinden, wie hoch die Paratuberkuloseprävalenz unter Wildkaninchen ist, wurden in Großbritannien aus 2 Landkreisen zwischen 2002 bis 2004 insgesamt 487 Wildkaninchen auf MAP untersucht. Es stellte sich heraus, dass die Paratuberkuloseprävalenz unter Wildkaninchen an einem Standort 39,7\% und an anderem Standort 23,0\% betrug (100).

MAP wurden auch aus Carnivoren und Omnivoren isoliert: Koyote, Wildkatze, Opossum, Stinktier, Waschbär und Rotfuchs (4).

Braunbären können ebenfalls als Reservoir und Überträger der MAP-Erreger dienen. MAPErreger wurden sowohl aus den Nieren eines Braunbären als auch aus der Darmmukosa von zwei weiteren Tieren isoliert (105).

Histologische und kulturelle Untersuchungen in Großbritannien zeigten, dass die Tierarten Fuchs, Krähe, Saatkrähe, Dohle, Ratte, Waldmaus, Feldhase und Dachs als Reservoir und Überträger der MAP-Erreger für Wiederkäuer in Frage kommen können (9).

Bei Primaten verläuft die Krankheit mit klinischen Symptomen. In einer Herde von 38 Stummelschwanz-Makaken waren 29 Tiere mit dem MAP-Erreger infiziert und schieden diesen auch über den Kot aus. Innerhalb von fünf Jahren kam es zu 13 Todesfällen in dieser Herde. Die klinischen und pathologischen Erscheinungen bei diesen Affen ähnelten der Paratuberku- 
lose beim Wiederkäuer. Mit Hilfe eines ELISAs konnten Antikörper gegen MAP bei 79-84\% aller Tiere gefunden werden (118).

Zurzeit wird diskutiert, ob die John'sche und die Crohn'sche Erkrankung durch das gleiche Bakterium ausgelöst werden. MAP konnte aus dem Darm von an Morbus Crohn erkrankten Menschen mittels Anzucht isoliert bzw. die DNS mit Hilfe der PCR nachgewiesen werden $(27,112,196)$.

\subsubsection{Wirtschaftliche Bedeutung}

Die Paratuberkulose verursacht bei betroffenen Rinderherden beachtliche wirtschaftliche Einbußen. Diese entstehen durch Rückgang der Milchleistung, verlangsamte Gewichtszunahme bei Masttieren und durch Abmagerung und Tod klinisch kranker Tiere. Infizierte Tiere erzeugen durchschnittlich 7,7\% weniger Milch und haben eine um 2,8 Jahre niedrigere Lebenserwartung als gesunde Kühe. Sie werden häufiger unfruchtbar, die Zwischenkalbezeit ist verlängert und die Tiere werden oft vor dem Erreichen ihrer Laktationshöchstleistung geschlachtet (18). Die verringerte Milchmenge kombiniert mit geringerem Proteingehalt, ist verbunden mit schlechterer Futterverwertung. Die infizierten Tiere erkranken 4-5 Mal häufiger an Mastitis und sind empfänglicher für andere Krankheiten, wodurch zusätzliche Behandlungskosten entstehen. Wirtschaftliche Verluste entstehen auch durch die Durchführung diagnostischer Tests sowie die vermehrt anfallende Reinigung und Desinfektion in betroffenen Betrieben. Die wirtschaftlichen Verluste der Milch-produzierenden Betriebe werden z.B. für den USBundesstaat Wisconsin auf über 50 Millionen Dollar, für die gesamte USA auf 1,5 Milliarden Dollar jährlich geschätzt (122).

Eine durch Paratuberkulose betroffene ungarische Milchherde mit 500 Tieren wurde drei Jahre lang untersucht. Es wurde festgestellt, dass die jährliche Milchmenge der gesamten Herde um 49474 Liter reduziert war. Pro Tier wurden 1030 Liter weniger Milch ermolken. Die durchschnittliche Lebensdauer war von 63,9 Monaten auf 57,0 Monate reduziert (106).

Um die Verluste, welche durch Paratuberkulose entstehen, messen zu können, wurden in 20 Staaten der USA 2542 Milchbestände serologisch mit ELISA untersucht. Es hatte sich herausgestellt, dass die Betriebe, die serologisch positive Tiere hatten, $100 \$$ Verlust pro infiziertem Tier im Vergleich zu paratuberkulosefreien Betrieben erlitten. Die Verluste entstanden durch verringerte Milchmenge und den Ersatz infizierter Tiere. In Betrieben, wo die Paratuberkuloseprävalenz mindestens $10 \%$ betrug, entstand pro erkranktem Tier ein Verlust von 200\$. Tiere in Betrieben, die an Paratuberkulose erkrankten, produzierten $700 \mathrm{~kg}$ weniger 
Milch als gesunde Tiere. Im Durchschnitt verursachte die Paratuberkulose in USMilchbeständen um $22 \$$ bis $27 \$$ verringerte Produktivität pro Kuh oder 200 bis 250 Millionen Dollar allgemein (143).

Um den Rückgang der Milchleistung in subklinisch infizierten Herden festzustellen, wurden von 90 Herden 2395 Rinder serologisch mittels ELISA auf MAP untersucht. Die Untersuchungen ergaben, dass ELISA-positive Tiere mit einer durchschnittliche Melkdauer von 305 Tagen in der ersten Laktation 573 Liter und in der fünfte Laktation 1273 Liter Milch weniger gaben (120). Um einen Zusammenhang zwischen subklinischer Paratuberkulose und produzierter Milchmenge feststellen zu können, wurden 1653 Rinder in Wisconsin serologisch mittels ELISA auf MAP untersucht. Von den untersuchten Tieren waren 147 Tiere positiv und 1506 Tiere negativ. Im ELISA positive Tiere gaben im Durchschnitt 376 Liter Milch weniger als antikörperfreie Tiere (141).

Die Daten, die vom National animal health monitoring system im Jahre 1996 stammten, wurden verwendet, um die verringerte Milchmenge pro Kuh messen zu können. Die Untersuchungen ergaben, dass sich die Verluste in leicht infizierten Herden im Durchschnitt auf $179 \mathrm{~kg}$ Milch, bzw. 51\$, in mittelmäßig infizierten Herden auf 288kg Milch bzw. $83 \$$ und in stark verseuchten Betrieben auf 748kg Milch bzw. 214\$ beliefen (143).

Um jährliche Verluste, die durch Paratuberkulose in Kanada entstehen, zu beziffern, wurde eine ,partial-budget“-Analyse durchgeführt. In dieser Analyse wurden Mortalität, frühzeitiges Entfernen der Tiere, verringerte Milchmenge und Verluste, die durch verlängerte Zwischenkalbezeit entstehen, berücksichtigt. Die Daten für die Seroprävalenz 1998-2003 stammten aus 8 Provinzen. Es wurden insgesamt 373 Betriebe untersucht. Die Untersuchungen ergaben, dass bei einer Herdenprävalenz von $12,7 \%$ pro Tier 49 kanadische Dollar Verluste entstehen $(24,206)$.

Schafsherden in Australien erleiden beträchtliche wirtschaftliche Schäden, die durch Tierverlust entstehen. Die Untersuchungen wurden über einen Zeitraum von 3 Jahren (2002-2004) durchgeführt. Die Herdengröße betrug zwischen 3500 und 20000 Schafen. Um den Anteil der Verluste, die durch Paratuberkulose entstanden, feststellen zu können, wurden histologische Gewebeuntersuchungen an verendeten und klinisch kranken Tieren durchgeführt. Die Mortalitätsrate, die durch Paratuberkulose verursacht wurde, betrug 6,2\%; 7,8\% und 14,6\% für die Jahre 2002, 2003 und 2004. Die wirtschaftlichen Verluste wurden anhand der Gross Marginal Analysis für die entsprechenden 3 Jahre berechnet. Die Berechnungen ergaben, dass das durchschnittliche jährliche Einkommen wegen Paratuberkulose um mindestens $13750 \$$ reduziert war (20). 
Um die Reduktion der Milchmenge, die durch Paratuberkulose entsteht, bestimmen zu können, wurden von 1052 Milchkühen 21 Tage vor der Abkalbung Kotproben entnommen und anhand einer Kotkultur untersucht. Die Untersuchungen ergaben, dass 84 Tiere kulturell positiv waren. Von den 84 positiven Tieren schieden 46\% den Erreger in geringen Mengen, 26\% in mittleren Mengen und 28\% in großen Mengen aus. Die reduzierte Milchmenge wurde mit Hilfe der multivariablen Analysemethode berechnet. Die Tiere, die den Erreger in geringen Mengen ausschieden, produzierten 537 Liter Milch weniger im Jahr bzw. 1,4 Liter Milch weniger pro Tag. Die Tiere, die den Erreger in mittleren Mengen ausschieden, produzierten im Jahr 1403 Liter weniger Milch, bzw. 5,2 Liter Milch weniger pro Tag. Die Tiere mit hoher Ausscheidung produzierten 1534 Liter Milch weniger im Jahr bzw. 7,5 kg Milch pro Tag weniger als gesunde Tiere (156).

Um herauszufinden, ob es wirtschaftlich wäre, an den Bekämpfungsprogrammen gegen Paratuberkulose teilzunehmen, wurde in Frankreich eine Studie durchgeführt. Es wurde insgesamt von 15490 Kühen aus 569 Betrieben die tägliche durchschnittliche Milchmenge pro Kuh gemessen. Es wurde berücksichtigt, ob die Tiere ELISA-positiv, PCR- bzw. kulturell-positiv oder Ziehl-Neelsen-positiv waren. Es hatte sich herausgestellt, dass bei Tieren, die ELISApositiv waren, die Milchmenge 1,58-2,51 kg weniger, bei kulturell-positiven 3,30-5,36 kg weniger und bei Ziehl-Neelsen positiven 2,03-7,20 kg weniger betrug als bei gesunden Tieren (10).

2.4.4

\section{Vorkommen, Übertragung und Ausscheidung}

Als Infektionsquelle dienen Kot und Milch von ausscheidenden Tieren. Gesunde Tiere infizieren sich durch orale Aufnahme des Erregers. Da dieser sehr widerstandsfähig gegenüber Umwelteinflüssen und Desinfektionsmitteln ist, kann er jahrelang auf Weiden, in Wasserstellen oder auf Ackerflächen lebensfähig bleiben und ist somit eine permanente Infektionsquelle. Die Krankheit kann auch mit Gegenständen übertragen werden, die durch den Erreger kontaminiert sind wie z.B. Futter, Einstreu, Arbeitskleidung, Gerätschaften (224). Eine Übertragung auf Wildwiederkäuerarten ist durch kontaminierte Weiden und Wasserstellen ebenfalls möglich (162). In den Richtlinien des Landes Nordrhein-Westfalen für die Sanierung Paratuberkulose-infizierter Rinderbestände wird daher gefordert, Rinder von anderen Wiederkäuern (Schafen, Ziegen, Damwild) räumlich zu trennen (132).

Neugeborene infizieren sich in den ersten Lebenstagen durch die Aufnahme erregerhaltigen Kolostrums oder durch das Saugen an kotverschmutzten Zitzen und verunreinigte Einstreu 
$(123,201)$. Auch kontaminierte Milch stellt eine Ansteckungsquelle dar. Deshalb ist es ratsam, bei der Gewinnung von Biestmilch auf ausreichende Hygiene zu achten, denn Kotreste eines Ausscheidertiers im Melkeimer können für ein Kalb eine ausreichende Infektionsdosis bilden. Mangelnde Geburtshygiene kann ebenfalls zur Infektion des Kalbes führen, wenn die Abkalbebox kontaminiert oder der Genitalbereich durch Kot verunreinigt ist (178).

Subklinisch infizierte Tiere scheiden den Erreger zunächst intermittierend aus. In diesem Stadium sind keine klinischen Zeichen bemerkbar $(33,71)$. Die Ausscheidung erfolgt über Kot, Milch oder Sperma. Von der Ausscheidung über den Kot geht die größte Kontaminationsgefahr aus. Eine intrauterine Infektion des Fetus ist ebenfalls nicht ausgeschlossen. Es besteht eine 25\%-ige Wahrscheinlichkeit, dass eine klinisch an Paratuberkulose erkrankte Kuh ein infiziertes Kalb zur Welt bringt (176).

\section{5}

\section{Diagnoseverfahren}

Die Diagnose der Paratuberkulose gestaltet sich aufgrund des Verlaufs der Erkrankung schwierig. In der präklinischen Phase ist eine Diagnose erschwert, da MAP intermittierend ausgeschieden wird und auch die humorale Immunantwort nicht vollständig in Erscheinung tritt $(29,188)$.

Für die Bekämpfung der Paratuberkulose und die Sanierung betroffener Herden ist neben der Einhaltung von Hygienemaßnahmen seitens der Landwirte der Einsatz geeigneter diagnostischer Methoden von großer Bedeutung. Dabei ist wünschenswert, dass die verwendeten diagnostischen Tests alleine oder in Kombination möglichst hohe Sensitivität und Spezifität aufweisen, um falsch positive oder falsch negative Ergebnisse auszuschließen (45).

Bei den Diagnoseverfahren unterscheidet man zwischen dem direkten und dem indirekten Erregernachweis. Während beim direkten Erregernachweis das Vorhandensein des Erregers selbst oder seiner DNS nachgewiesen wird, erfolgt beim indirekten Erregernachweis ein Nachweis der Immunantwort auf MAP.

\subsubsection{Direkter Erregernachweis}

Für den Nachweis von MAP stehen verschiedene Methoden zur Verfügung, die direkt den Erreger bzw. die Erreger-DNS nachweisen. Eine einfache und kostengünstige Methode ist der mikroskopische Nachweis säurefester Stäbchenbakterien durch die Ziehl-Neelsen-Färbung. Die MAP-Erreger sind schlanke Stäbchen, die in Nestern angeordnet vorliegen. Die typische 
Anordnung der Bakterien zueinander ist durch Ausbildung intrazellulärer Filamente bedingt (121). Der Nachteil dieser Methode liegt darin, dass nur jene Tiere erkannt werden, welche den Erreger in großen Mengen ausscheiden. Subklinisch infizierte Tiere können nicht erkannt werden (126). Ein weiterer Nachteil dieser Methode liegt darin, dass andere, im Magendarmtrakt von Tieren vorkommende, nicht pathogene Mycobakterien mikroskopisch nicht abgegrenzt werden können $(12,192)$.

$\mathrm{Zu}$ den direkten Nachweismethoden gehört auch der kulturelle Erregernachweis. Hierbei handelt es sich um eine hochspezifische und zuverlässige Methode, die bis heute als Goldstandard gilt $(31,39)$. Jedoch handelt es sich um ein langwieriges Verfahren, da die Bebrütungszeit 6-8 Wochen beträgt.

$\mathrm{Zu}$ den direkten Nachweismethoden gehört auch der Nachweis der Erreger-DNS mittels PCR. Bei diesem Verfahren wird DNS aus Kultur, Gewebe, Kot, Milch oder Sperma extrahiert und mittels PCR IS 900 amplifiziert.

\subsubsection{Mikroskopischer Erregernachweis}

Der mikroskopische Erregernachweis säurefester Stäbchen mittels Ziehl-Neelsen-Färbung ist eine einfache, schnell durchführbare und kostengünstige Methode. Die mikroskopische Methode findet bei der Untersuchung von Kot- und Rektumschleimhautproben sowie postmortal bei der Untersuchung von Abstrichen der Darmschleimhaut und Mesenteriallymphknoten Anwendung. Bei der Ziehl-Neelsen-Färbung sind mikroskopisch deutlich rot angefärbte Stäbchen in charakteristischen Nestern erkennbar. Vereinzelt liegende säurefeste Stäbchen können bei dieser Untersuchung nicht gewertet werden, da es sich meist um atypische, saprophytäre Mycobakterien handelt, die auch im Kot gesunder Tiere vorkommen. Als Untersuchungszeit für die mikroskopische Betrachtung eines Probenausstriches werden 5-10 Minuten veranschlagt.

Die Phenol-Acridin-Orange-Fluoreszenz Färbung ist schneller durchzuführen als die Färbung nach Ziehl-Neelsen. Gefärbte Ausstriche können ab einer 200-fachen Vergrößerung mikroskopiert werden. Gelangen Mykobakterien in das Blickfeld, zeigen diese eine strahlend rote bis orange Färbung vor einem fast schwarzen Hintergrund (182). In Zweifelsfällen wird eine 1000-fache Vergrößerung (entspricht der Anfangsvergrößerung bei der Ziehl-NeelsenFärbung) verwendet. Der Vergleich der mikroskopischen Untersuchungsergebnisse mit dem kulturellen Erregernachweis aus Kot infizierter Tiere ergab für die Mikroskopie eine Sensitivität von 46\% und eine Spezifität von 93,8\% (96). 


\subsubsection{Kultureller Erregernachweis}

Die kulturelle Untersuchung von Kot- oder Gewebeproben wird als die zuverlässigste Methode zur Diagnosesicherung angesehen, um besonders in Betrieben mit einer hohen Prävalenz klinisch unauffällige Tiere zu ermitteln (127).

Wegen der langen Inkubationszeiten und intermittierenden Erregerausscheidung ist es jedoch möglich, dass falsch negative Ergebnisse auftreten (177). Die entscheidende Voraussetzung für die erfolgreiche Kultivierung des Erregers ist die Dekontamination der zu untersuchenden Proben. Die jede Kotprobe begleitende Flora von unspezifischen Keimen kann durch eine Vielzahl von Reagenzien inaktiviert werden, ohne MAP wesentlich zu schädigen. Eine Möglichkeit besteht darin, die aufgeschlossene Probe mit Oxalsäure und Natronlauge zu behandeln. Dieses Dekontaminationsverfahren wird häufig angewendet. Ein wesentlicher Schritt zur Verbesserung des kulturellen Nachweisverfahrens gelang mit der Einführung des Hexadecylpyridiniumchlorids zur Beseitigung unerwünschter Begleitkeime. Gegenüber früher eingesetzten Chemikalien führt dieser zu einer wesentlichen Arbeitserleichterung, verbunden mit einer höheren Ausbeute an vermehrungsfähigen Paratuberkuloseerregern (122).

Heutzutage wird Eidotter-Medium nach Harrold (Harrold's egg yolk medium) zur Kultivierung verwendet. Wird diesem Nährboden Mycobactin J hinzugefügt, kann die Bebrütungszeit von 12 auf 8 Wochen verkürzt werden. Auch unter Verwendung einiger Elemente des Roche MB Check ${ }^{\circledR}$ Systems kann MAP erfolgreich kultiviert werden (159).

Nach Untersuchungen von Jorgensen besitzt die Kotkultur im klinischen Stadium eine Sensitivität von 100\% (97). Gegenüber der kulturellen Untersuchung des Ileozäkallymphknotens besitzt die Kotkultur latent erkrankter Tiere jedoch nur eine Sensitivität von 33\%. Die Nachweisgrenze des kulturellen Erregernachweises liegt bei 100 koloniebildenden Einheiten pro Gramm Kot (42). Die Zahl der ausgeschiedenen Erreger beträgt bei klinisch manifestierter Erkrankung mindestens $10^{6}$ Keime pro Gramm Kot (128)

\subsubsection{Molekularbiologische Verfahren}

\subsection{PCR}

Die Polymerase-Kettenreaktion (PCR, Polymerase chain reaction) beruht auf dem einfachen Prinzip der Replikation von DNS mit Hilfe zweier synthetischer Oligonukleotidprimer und einer thermostabilen DNS-Polymerase im Reaktionsgefäß. Mittels PCR ist es möglich, aus einem komplexen Ausgangsmaterial an DNS größere Mengen eines bestimmten Bereiches zu 
synthetisieren. Durch die Entdeckung der für MAP spezifischen Insertionssequenz 900 (IS 900) ist dies auch selektiv möglich. Hierbei handelt es sich um eine DNS-Sequenz mit der Länge von $1451 \mathrm{bp}$, welche in 15-20 Kopien im MAP-Genom vorhanden ist (75). Die bisher von verschiedenen Arbeitsgruppen entwickelten, auf der IS 900 basierenden Primerpaare, die zum Erregernachweis mittels PCR eingesetzt wurden, binden ausnahmslos am 5'-Ende des Sequenz zwischen den Nukleotiden 15 und 766. Vergleiche zwischen der IS 900 und zwei eng verwandten Insertionssequenzen, der von M. avium ssp. silvaticum und IS 110 von Streptomyces coelicolor ergaben weitreichende Homologien im 3'-Bereich der IS 900. Daher wurde dieser Bereich für die Detektion von MAP als ungeeignet erachtet. Einige Forscher (75, 129) konstruierten eine biotinylierte Sonde, deren Sequenz die Nukleotide 818 bis 1331 der IS 900 umfasste und in DNS-Präparationen aus Kot sowohl mit MAP als auch mit M. silv. hybridisierte. Danach wurden mit Streptavidin beschichtete magnetische Partikel zugegeben. Mittels eines magnetischen Felds wurden sowohl die Partikel als auch daran gebundene Sonden mit der DNS von MAP oder M. silv. isoliert. Anschließend erfolgte der Nachweis des jeweiligen Erregers mit Hilfe der spezifischen Primer. Die auf diese Weise ermittelte Sensitivität lag bei 10 Genomkopien/ml Elutionspuffer. In Kotproben konnten 10 bis 100 Erreger/g Fäzes nachgewiesen werden. Die Sensitivität der PCR zur Detektion von MAP ließ sich um mindestens eine $\log ^{10}$-Verdünnungsstufe steigern, wenn auf die PCR ein Southern Blot folgte. Ebenfalls mit dem Ziel, die Sensitivität zu steigern, wurden eine nested $(39,64)$ sowie eine semi-nested-PCR durchgeführt (172). Bei der Detektion des Erregers nach der Extraktion von DNS aus Kotproben wird die PCR-Reaktion häufig durch Stoffe wie Bilirubin oder Gallensalze, die zusammen mit der DNS eluiert werden, inhibiert (227). Dies konnte mit Hilfe der bereits erwähnten Streptavidin-beschichteten magnetischen Partikel verhindert werden. Um die Inhibition durch im Kot vorkommende Substanzen zu vermeiden, wurde die PCR aus Milch und Blut durchgeführt (194).

Durch Vorbehandlung mit polyklonalen Kaninchenantikörpern gegen MAP, die an Immunglobulin-beschichtete magnetische Partikel gebunden waren, konnte MAP selektiv aus Milchproben isoliert werden (73). Bei einer Aufreinigung der DNS ohne diese Vorbehandlung lag die Nachweisgrenze der IS 900-PCR bei $10^{5} \mathrm{KBE} / \mathrm{ml}$ Milch, wobei die Sensitivität der PCR durch die Vorbehandlung auf $10^{3} \mathrm{KBE} / \mathrm{ml}$ Milch gesteigert werden konnte (74). Zur Identifikation von MAP-Ausscheidern wurde eine PCR entwickelt. Als Grundlage für diese PCR dient die IS-MAP 02, welche aus 1674 Basenpaaren besteht und im gesamten Genom in 6 Kopien vorhanden ist. Die Sensitivität dieser PCR war vergleichbar mit jener der IS 900-PCR. Um die Spezifität der IS-Map 02 zu evaluieren, wurde DNS aus MAP, M. phlei, 
M. avium subsp. avium, M. fortuitum, M. scofulaceum, M. smegmatis und M. gordonae extrahiert und die PCR durchgeführt. Nur DNS von MAP konnte nach der Amplifikation detektiert werden. Es gibt abweichende Meinungen darüber, ob die IS 900 spezifisch für MAP ist. Zwei Studien haben gezeigt, dass die IS 900 bei M. cookii und M. scrofulaceum 94\% bzw. 79\% Homologie mit der IS 900 von MAP aufweist $(47,65)$. Es scheint, dass die auf dem IS Map 02 Element basierende PCR als gute Alternative zu der IS 900-PCR dienen kann (190).

In einer Untersuchung wurden 14 nordamerikanische Bisons, die klinische Symptome für Paratuberkulose zeigten, gemerzt. Die entnommenen Gewebeproben und Kotproben wurden für die kulturelle Anzucht genutzt und mikroskopisch mit Hilfe der Ziehl-Neelsen-Methode untersucht. Für die PCR wurde aufbereitete DNS genutzt. Die kulturelle Anzucht von Kotproben ergab, dass 35,7\% der Tiere mit MAP infiziert waren. Die Untersuchung von Kulturen aus Gewebeproben ergab jedoch eine Infektiosrate von 85,7\%. Die PCR detektierte 100\% der Kotproben und 81,2\% der Gewebeproben als positiv. Die Ziehl-Neelsen Färbung hingegen ergab nur, dass $50 \%$ der Tiere infiziert waren, von den Gewebeproben wurden 21,4\% als positiv erkannt (91).

Um die Praxistauglichkeit eines TaqMan PCR-Assays zu überprüfen, wurde dieser mit verschiedenen ELISAs evaluiert. Als Vergleichstest galten 2 kommerzielle Serum-ELISAs und ein kommerzieller Milch-ELISA. Es wurden insgesamt 347 Tiere aus 7 paratuberkulosefreien Herden und 1808 Tiere aus 7 infizierten Herden untersucht. Die Untersuchungen ergaben, dass der TaqMan PCR-Assay eine Spezifität von 99,7\% aufweist. Die Sensitivität des PCRAssay betrug bei leicht ausscheidenden Tieren 4\% und 76\% bei den Tieren, die den Erreger in großen Mengen ausschieden. Es ist ratsam, den TaqMan PCR-Assay nur für stark verseuchte Betriebe zu verwenden, da die Sensitivität des ELISAs bei leicht ausscheidenden Tieren gröBer ist als die des TaqMan PCR-Assays (221).

Basierend auf der ,phage display“-Technologie wurde eine ,peptide-mediated magnetic separation“ Technik entwickelt, um die selektive Isolierung von MAP-Erregern aus Sammelmilch zu beschleunigen. Dazu wurden aus einer kommerziellen Phage-Peptide Bibliothek rekombinante Bakteriophagen isoliert, welche in der Lage waren, an M. ptb Erreger spezifisch zu binden. Dieses hoch affine aMptD Peptid wurde verwendet, um die MAP-Erreger mittels Peptidvermittelter „,capture“ PCR, basierend auf dem MAP-spezifischen Element IS Mav2, in Milch nachzuweisen. Die Peptid aMptD-vermittelte ,capture“ PCR ermöglichte neben dem Nachweis von nur 100 Erregern pro ml gespikter Milch reproduzierbar den Erregernachweis in Milchproben von infizierten Kühen und in Sammelmilchproben von serologisch positiven Herden. Da die Peptid-vermittelte „capture“ PCR ausschließlich auf standardisierten Reagen- 
zien basiert, könnte sie für die routinemäßige Untersuchung von Sammelmilchproben eingesetzt werden (195).

Nach Ablauf der PCR werden die PCR-Produkte mit Hilfe der Agarosegelelektrophorese analysiert. Fluoreszenzfarbstoffe wie Ethidiumbromid oder SYBR Green, welche in doppelsträngige DNS interkalieren und durch ultraviolettes Licht angeregt werden, können die Amplifikate visualisieren.

Um die diagnostische Sensitivität der bakteriologischen Kulturmethode und der nested PCR Methode zu vergleichen, wurden von 40 klinisch an Paratuberkulose erkrankten Rindern Kotproben gewonnen und mittels Kotkultur und nested PCR untersucht. Durch die Kotkulturmethode wurden 21 von 40 erkrankten Rindern (52,5\%), durch die nested PCR 36 von 40 erkrankten Rindern (90\%) detektiert. Diese Untersuchungen zeigen, dass die nested PCR als effektive und schnelle diagnostische Methode eingesetzt werden kann (185).

In einer weiteren Untersuchung wurden 134 Milchproben und 110 Kotproben von 146 Tieren aus 14 durch Paratuberkulose betroffenen Herden genommen. Es wurden die Kulturmethode, PCR und nested PCR verwendet, um Milchproben zu untersuchen und die Ergebnisse mit denen der Kotkultur zu vergleichen. Es konnte festgestellt werden, dass die Ergebnisse der Kotproben und der Milchproben nicht miteinander übereinstimmten. Einige Tiere wurden nur durch die Milchuntersuchung als Ausscheider identifiziert, wohingegen andere Tiere ausschließlich durch die Kotuntersuchung als Ausscheider erkannt wurden. Da die Ausscheidung des Erregers in Kot und Milch nicht synchron stattfindet empfiehlt der Autor beide Tests für die Diagnostik einzusetzen, um alle Ausscheider ausfindig zu machen (70).

\subsection{Real-Time PCR}

Die Real-Time PCR ist eine Vervielfältigungsmethode für Nukleinsäuren, die auf dem Prinzip der herkömmlichen PCR beruht. Die Ergebnisse stehen direkt nach dem Ablauf zur Verfügung, eine gelelektrophoretische Auftrennung der Amplifikate ist nicht mehr erforderlich. Als Übertragungsmedium für die Temperatur wird beim Light Cycler $^{\mathrm{TM}}$ ein Luftstrom benutzt. Temperaturschritte von $20{ }^{\circ} \mathrm{C} / \mathrm{sec}$ können so überwunden werden. Dies ermöglicht den $\mathrm{Ab}$ lauf der Denaturierung der DNS, Anlagerung der Primer und Synthese der PCR-Produkte in weniger als $30 \mathrm{sec}$ (229). Um die Übertragung der Temperatur optimal gestalten zu können, werden Glaskapillaren mit einem hohen Oberflächen/Volumen-Verhältnis als Reaktionsgefäße benutzt. Gleichzeitig dienen sie als Messküvetten für die Fluoreszenzdetektion während der PCR. Die erfassten Fluoreszenzdaten werden sofort „in Echtzeit“ am Bildschirm darge- 
stellt. Für den Gebrauch der Real-Time PCR auf dem Light Cycler $^{\mathrm{TM}}$ stehen unterschiedliche Detektionssysteme zur Verfügung. Das SYBR ${ }^{\circledR}$ Green I-System bindet sequenzunabhängig an sich bildende doppelsträngige DNS. Dies löst eine Fluoreszenz aus. Die Stärke der Fluoreszenz wird am Ende jeder Elongationsphase ermittelt, wenn die gesamte DNS als Doppelstrang vorliegt. Die Wellenlänge beträgt $530 \mathrm{~nm}$, die Signalstärke verhält sich proportional zur Menge des gebildeten PCR-Produkts. Um eine qualititative Detektion des PCR-Produkts zu ermöglichen, nutzt man die spezifische Schmelztemperatur des PCR-Amplifikats. Hierdurch werden die Identifizierung des PCR-Produkts und die Differenzierung von unspezifischen Produkten, wie z.B. Primer-Dimeren, ermöglicht. Diese Schmelzkurvenanalyse erfolgt im Anschluss an die PCR. Durch langsamen Temperaturanstieg und kontinuierliche Messung der Fluoreszenz wird die spezifische Schmelztemperatur des gebildeten PCR-Produktes ermittelt. Sie definiert sich als die Temperatur, bei der 50\% der DNS einzelsträngig und 50\% der DNS doppelsträngig vorliegen. Sie ist besonders von der Länge, der Basenabfolge und dem GC-Gehalt des Amplifikats abhängig (50, 161).

Eine weitere Methode ist die Detektion mittels Hybridisierungssonden. Sie bietet wesentlich spezifischere Möglichkeiten. Die Hybridisierungssonden bestehen aus einem Paar sequenzspezifischer Oligonukleotide, die an den einander zugewandten Enden mit unterschiedlichen Fluoreszenzfarbstoffen markiert sind. Durch ihre Sequenz binden die Oligonukleotide während der Anlagerungphase in unmittelbarer Nähe zueinander an die DNS des zu amplifizierenden Fragments. Nur bei dieser Nähe kommt der so genannte „Fluorescence Resonance Energy Transfer“ (FRET) zustande. Das 3' Ende der ersten Sonde ist mit Fluoreszein markiert, das 5' Ende der anderen mit Light Cycler $^{\mathrm{TM}}$-Red 640 oder 705. Am Ende der Anlagerungsphase wird das Fluoreszein von der optischen Einheit des Light Cyclers ${ }^{\mathrm{TM}}$ angeregt, so dass die erste Sonde (Donorfluorophor) grünes Licht emitiert. Dies regt den Fluoreszenzfarbstoff der zweiten Sonde (Akzeptorfluorophor) zur Emission von Fluoreszenz in einer messbaren Wellenlänge an. Die Fluoreszenz wird nur erzeugt, wenn beide Sonden an die Zielsequenz in unmittelbarer Nähe zueinander binden. Die ermittelte Fluoreszenz ist proportional zur Menge des gebildeten PCR-Produktes.

Mit einer Light Cycler ${ }^{\mathrm{TM}}$ PCR mit SYBR ${ }^{\circledR}$ Green I konnte ein 587 bp und ein 278 bp DNSFragment aus der für MAP spezifischen IS 900 detektiert werden. Dabei wurde eine Nachweisgrenze von 10 Genomkopien für das größere und 100 Genomkopien für das kleinere Fragment erreicht. Bei der Detektion mit Hybridisierungssonden wurde für das 278 bp Fragment eine Nachweisgrenze von 10 Genomeinheiten ermittelt (172). 
Es wurde eine Light Cycler ${ }^{\mathrm{TM}}$-PCR (LC-PCR) für Milchproben basierend auf der Sequenz F57 von MAP entwickelt. Die F57 Sequenz liegt einfach im gesamten MAP-Genom vor und wurde noch bei keinem anderen Mikroorganismus nachgewiesen. Sie ist daher spezifisch für MAP. Die LC-PCR ist in der Lage, MAP-Erreger $\left(2 * 10^{1}\right.$ bis $\left.2 * 10^{6}\right)$ in positiven Proben quantitativ zu bestimmen. Diese Methode stellt eine Alternative zu den anderen Untersuchungsmethoden dar, um MAP-Erreger aus Tankmilch zu isolieren (204).

Es wurde eine Triplex Real-Time PCR entwickelt und validiert, um MAP-Erreger im Rinderkot sicher diagnostizieren zu können. Die Validierung wurde gemäß den Empfehlungen der International Organisation for Standardization für die PCR und Real Time PCR durchgeführt. Um die Spezifität testen zu können, wurden 105 Mykobakterien-Stämme bovinen, ovinen und humanen Ursprungs und 100 weitere Bakterien-Stämme ausgewählt. In den Untersuchungen wurden alle 105 MAP-Stämme korrekt als MAP identifiziert. Die restlichen nicht 34 MAP-Erreger und 66 nicht Mykobakterien-Stämme zeigten auch eine hohe Selektivität und es gab keine falsch positiven oder negativen Reaktionen. Die Untersuchungen ergaben, dass der Einsatz der Triplex-PCR eine gute Alternative zu anderen diagnostischen Verfahren darstellt (173).

Es ist bekannt, dass die IS 900 Ähnlichkeiten zu anderen Mycobacterium avium-Stämmen aufweist. Daher ist es nicht auszuschließen, dass die IS 900-PCR falsch positive Ergebnisse aufweist. Um Fehler in der Diagnose ausschließen zu können, wurde vom F 57 Gen, das sich im IS 900 Bereich befindet, eine Real-Time PCR entwickelt und evaluiert. Um diesen Test evaluieren zu können, wurden 112 Proben untersucht: 56 davon waren Fäkalproben von klinisch an Paratuberkulose erkrankten Tieren, 155 weitere Proben enthielten andere Mykobakterien oder Nicht-Mykobakterien. Es wurden keine falsch positiven Ergebnisse erhalten. Aufgrund der Tatsache, dass das F 57 Gen nur in einfacher Kopie im Genom vorliegt, kann dieser Test im Vergleich zur IS 900-PCR eine geringere Sensitivität sowie höhere Spezifität aufweisen (84). Um MAP aus Bullensperma zu isolieren, wurde eine Real-Time PCR basierend auf der IS 900 etabliert. Die DNS wurde aus Sperma durch Phenol-Chloroform-Extrakt isoliert. Gewohnlich der DNS welche aus Gewebeproben isoliert wird enthält Substanzen, welche die Durchführung der PCR inhibieren (227). Der Einsatz von Phenol und Chloroform trägt dazu bei, dass PCR-Inhibitoren aus dem Sperma entfernt werden. Diese Real-Time PCR ermöglicht es, bis zu 10 Erreger pro $100 \mu \mathrm{l}$ zu detektieren. Da kein Sperma von an Paratuberkulose erkrankten Bullen zur Verfügung stand, wurde diese Real-Time PCR Methode anhand künstlich gespikter Spermaproben etabliert. Aufgrund dessen ist keine Aussage darüber möglich, inwiefern diese Methode dazu geeignet ist, MAP-Erreger in natürlich infiziertem Sperma 
nachzuweisen. Deshalb ist es schwer, eine Aussage darüber zu machen, wie effektiv diese Real-Time PCR in Wirklichkeit ist (85).

\subsection{Restriction Fragment Length Polymorphismus (RFLP)}

Der MAP-Erreger wird in 3 Gruppen unterteilt: S (sheep) Typ, C (cattle) Typ und I (intermediate) Typ $(8,12,38,138)$. Diese Varianten werden auch als Typ I, II und III bezeichnet (54, $138,193)$ und sind nicht wirtsspezifisch $(8,138,169)$. Um die genetische Variabilität des MAP-Erregers zu untersuchen, wurden 71 Isolate aus 14 Rinderherden mittels RFLP (restriction fragment length polymorphismus) basierend auf der IS 900 untersucht. Die Untersuchungen zeigten, dass alle 71 Proben der Gruppe C angehörten. Untersuchte MAP-Erreger gehörten zu 17 verschiedenen Genotypen (138). In Norwegen waren die Rinder von der Paratuberkulose nicht so stark betroffen wie Ziegen. Deshalb war man der Meinung, dass die MAPIsolate aus Ziegen für Rinder harmlos wären. Um diese Frage beantworten zu können, wurden 51 Isolate aus Ziegen und 4 Isolate aus Rindern, die anhand der IS 900 als MAP identifiziert waren, mit Hilfe des RFLP untersucht. Die Untersuchungen ergaben, dass alle Isolate aus Rindern und 84\% der Isolate aus Ziegen dasselbe RFLP-Muster (B-C1) aufwiesen. Man kann daraus folgern, dass keine Wirtsspezifität für MAP existiert (57). Um Vorkommen und Verteilung verschiedener Stämme bei unterschiedlichen Tierarten bestimmen zu können, wurden in Australien 328 Isolate mittels RFLP untersucht. Die Isolate stammten von Rindern, Schafen und anderen Tierarten. Die Untersuchungen ergaben, dass die Schafe stets mit „S“ Stämmen, aber Rinder und andere Tierarten mit „C“ Stämmen infiziert waren. Ergebnisse dieser Untersuchung sollten jedoch keinesfalls zur falschen Schlussfolgerung führen, dass existierende „C, S und I“ Stämme absolut wirtsspezifisch sind (226).

\subsection{2}

\section{Indirekter Erregernachweis}

$\mathrm{Zu}$ den indirekten Nachweismethoden zählt man allergische Reaktionen und serologische Verfahren zur Ermittlung des Antikörpertiters. Eine der allergologischen Methoden ist der Johnin-Test. Für die Durchführung dieses Tests werden 0,1 ml Johnin-Lösung intrakutan injiziert. Tritt bereits nach zwei Stunden eine Schwellung im Bereich der Injektionsstelle auf, wird dies als unspezifische Reaktion gewertet. Wird nach 24-72 Stunden eine verzögerte Reaktion mit Umfangsvermehrung an der Injektionsstelle beobachtet, ist dies als positiv zu be- 
werten (121). Die Diagnose mit Hilfe des Johnin-Tests wird durch eine Kreuzreaktion mit anderen Mykobakterien, vor allem dem Erreger der bovinen Tuberkulose, erschwert (33). $\mathrm{Zu}$ den eingesetzten serologischen Verfahren gehören Komplementbindungsreaktion, Agargel-Immundiffusionstest und Enzyme Linked Immuno Sorbent Assay. Der Erfolg der eingesetzten Methode hängt von der Höhe des Antikörpertiters sowie der Sensitivität und Spezifität der Methode ab. Der Nachweis subklinisch infizierter Tiere ist nur teilweise möglich, da der Antikörpertiter bis zum Auftreten erster klinischer Symptome nur langsam ansteigt (40).

Die KBR war früher häufig im internationalen Handel mit Wiederkäuern vorgeschrieben (158). In mehreren vergleichbaren Untersuchungen mit verschiedenen ELISAs zeigte die KBR jedoch eine deutlich schlechtere Sensitivität (158).

Der AGIDT erzielt bei Schafen in einem späten Stadium der Erkrankung eine gute Sensitivität und eine 100\%-ige Spezifität (151). Bei einer Untersuchung mit subklinisch erkrankten Rindern ergab sich jedoch eine signifikant geringere Detektionsrate als in der KBR oder beim ELISA. Der AGIDT kann deshalb beim Rind nicht empfohlen werden (183).

\subsubsection{Serologischer Nachweis}

\subsection{Agargel-Immunodiffusionstest (AGIDT)}

Der Agargel-Immundiffusiontest (AGIDT) ist als diagnostische Methode zur Erkennung der Paratuberkulose weniger geeignet als die KBR (126). Durch die Adsorption der Patientenseren mit M. phlei konnte die Spezifität des Verfahrens verbessert werden (122). Die Sensitivität ist jedoch weiterhin geringer als die des ELISA. Diese Methode zeigt erst dann ein positives Ergebnis, wenn der Erreger bereits in großer Menge ausgeschieden wird. Merkal empfiehlt, den AGIDT zur Erkennung klinisch erkrankter Ausscheidertiere mit dem Vorteil einer schnelleren Diagnose gegenüber der kulturellen Untersuchung (122).

Dieser serologische Test eignet sich nach Überzeugung anderer Autoren nur als zusätzliche Methode zur Absicherung der Diagnose bei klinisch erkrankten Tieren. Zur Beurteilung subklinisch erkrankter Rinder wird das Verfahren als unzuverlässig bewertet. In einer Untersuchung von Sherman konnten für diesen Test eine Sensitivität von 18,9\% und eine Spezifität von $99,4 \%$ bestimmt werden (179).

Um Sensitivität und Spezifität von KBR und AGIDT bestimmen zu können, wurden die beiden Tests miteinander verglichen. Es wurden insgesamt 74 subklinisch infizierte Tiere, 154 nicht infizierte Tiere aus 6 Herden und 30 paratuberkulosefreie Tiere untersucht. Der Infektionsstatus der Tiere wurde anhand von mindestens 3 Kotkulturen definiert. Die Untersuchun- 
gen von subklinisch infizierten Tieren ergaben in KBR und AGIDT eine Sensitivität von $10,8 \%$ und $18,9 \%$. In der paratuberkulosefreien Gruppe wurde in KBR und AGIDT eine Spezifität von 97,4\% und 99,4\% festgestellt. Die negativen Ergebnisse von durch Paratuberkulose betroffenen Herden sollten daher mit Vorsicht betrachtet werden, da beide Tests nur eine niedrige Sensitivität bei subklinisch infizierten Tieren aufweisen (179).

Um die Sensitivität und Spezifität verschiedener serologischer Verfahren miteinander zu vergleichen, wurden 329 Tiere, 168 Kultur-positive und 161 antiköperfreie Tiere, mit verschiedenen serologischen Tests untersucht. Die Sensitivität betrug im modifizierten AGIDT, im dot immunoassay (DIA) und im ELISA jeweils 49\%, 42\%, 65\% sowie 68\%. Die Spezifität betrug jeweils 10\%, 8\%, 16\% und 14\%. Die Sensitivität der serologischen Tests ist höher, je mehr Erreger mit dem Kot ausgeschiedenen werden. Sowohl die Sensitivität als auch die Spezifität des ELISAs ist höher als im AGIDT, deshalb wird der ELISA für die Diagnostik der Paratuberkulose häufiger eingesetzt (209).

In einem Versuch wurden 32 klinisch an Paratuberkulose erkrankte und 43 antikörperfreie Schafe serologisch untersucht. Die Vergleichsuntersuchungen von ELISA und AGIDT haben eine Sensitivität von $86,4 \%$ und $100 \%$ in der multibazillären (lepromatosen) Form und 10$50 \%$ und $30 \%$ in der pauzibazillären (tuberkuloiden) Form ergeben. Die Spezifität betrug in beiden Tests $100 \%$ (35).

In einem Betrieb wurden 134 Schafe wegen chronischen Gewichtsverlusts gemerzt. Diese Tiere wurden auf Paratuberkulose untersucht. Hiervon waren 23 Tiere (17,2\%) AGIDTpositiv und 38 Tiere (28,3\%) ELISA-positiv. Von den 134 Schafen hatten 62 Tiere granulomatöse Schädigungen im Darm. Die Sensitivität dieser 62 untersuchten Tiere betrug im AGIDT 37,1\%, im ELISA 48,4\%. Die Spezifität betrug 100\% bzw. 88,9\%. Die Untersuchungen zeigen, dass die Sensitivität in beiden Tests bei klinisch kranken Tieren viel höher ist als bei subklinisch kranken Tieren (151).

Die sich für die Paratuberkulosediagnostik auf dem Markt befindlichen Rinder-ELISAs wurden für die Diagnostik von Lamas und Alpakas modifiziert. Es wurden 84 Lamas und 16 Alpakas, die antikörperfrei waren, mit Hilfe von drei ELISAs und AGIDT getestet, um die Spezifität verschiedener serologischer Verfahren evaluieren zu können. Die drei ELISAs wurden mit den Buchstaben A, B und C bezeichnet. Die Untersuchungen ergaben für die ELISAs (A, B und C) eine Spezifität von 48\%, 92\% bzw. 98\% und für den AGIDT 100\%. Die ELISAs wiesen eine niedrige Spezifität auf und konnten daher für die Diagnostik von Lamas und Alpakas nicht eingesetzt werden (130). 
In einer Studie wurden Blutseren von 48 Milchkühen, welche in drei verschiedenen ELISAs positiv waren, für die Evaluierung des AGIDT verwendet. Von 48 Tieren waren 21 Tiere ELISA positiv und 27 Tiere antikörperfrei. Im AGIDT waren 14 Tiere positiv, davon waren 2 Tiere falsch positiv und 34 Tiere negativ, hiervon waren 7 Tiere falsch negativ. Für den AGIDT wurden eine Sensitivität von 57\% und eine Spezifität von 92,5\% festgestellt. Obwohl der AGIDT eine kostengünstige und einfach durchzuführende Methode ist, ist er nicht in der Lage, subklinisch erkrankte Tiere zu detektieren (67).

In einer Studie wurden die Sensitivität und Spezifität von AGIDT, ELISA und von allergischen Hauttestmethoden mit der Bayesianischen Wahrscheinlichkeitsmethode verglichen. Insgesamt wurden 14 Herden mit 2465 Schafen auf Paratuberkulose untersucht. Fünf Herden (450 Tiere) wurden als nicht infiziert und neun Herden (2015 Tiere) als infiziert betrachtet.

Die Untersuchungen ergaben für AGIDT, ELISA und die allergischen Hauttests Spezifitäten von $99,0 \%$, 99,3\% und 98,7\%, die Sensitivität betrug 8,3\%, 8,0\% bzw. 73,3\%. Der AGIDT und ELISA sind spezifischer, aber weniger sensitiv. Allergische Hauttests sind sensitiver und können daher sowohl für die Einzeltier- als auch für die Herdendiagnostik eingesetzt werden. Der einzige Nachteil ist deren vergleichsweise niedrige Spezifität (164).

\subsection{Komplementbindungsreaktion (KBR)}

Die Komplementbindungsreaktion (KBR) wurde zuerst von Bang und Andersen angewandt. Ihr Einsatz führt jedoch aufgrund von Kreuzreaktionen mit M. tuberculosis und M. avium nur bei tuberkulosefreien Tieren $\mathrm{zu}$ befriedigenden Ergebnissen. Viele Forscher beobachteten auch in tuberkulosefreien Beständen eine geringe Anzahl unspezifischer Reaktionen und wiesen gleichzeitig auf die Unzulänglichkeiten bei der Diagnose klinisch nicht erkrankter Keimträger hin. Pöll lehnte die allgemeine Anwendung der KBR in der Untersuchung auf Paratuberkulose bei Tieren epidemiologisch unbekannter Herkunft wegen der unzureichenden Empfindlichkeit, fehlenden Spezifität und der dadurch bedingt hohen Anzahl falsch positiver Ergebnisse ab (153). Bei umfangreichen Blutuntersuchungen mittels KBR stellte Rankin fest, dass in nachweislich mit Paratuberkulose infizierten Herden mehr als 40\% der Tiere ein- oder mehrfach positiv reagierten. Aber auch in zwei nicht infizierten Herden waren 30\% der Tiere mindestens einmal positiv. Rankin lehnte es daher ab, sich bei einem Ausmerzungsprogramm für Paratuberkulose-infizierte Bestände allein auf die Ergebnisse der KBR zu stützen (157). Einige Forscher empfehlen für die Diagnose der Paratuberkulose beim Einzeltier, auch andere diagnostische Methoden zu verwenden, aufgrund der Tatsache, dass infizierte Tiere zeitweilig 
in der KBR negativ reagieren können (124). Durch vergleichende Untersuchungen stellte de Lisle fest, dass eine positive Relation zwischen Anzahl ausgeschiedener MAP-Erreger und Höhe des Antikörpertiters in der KBR besteht (56). Bei Evaluierung eines ParatuberkuloseELISAs wurde festgestellt, dass von nachweislich 156 subklinisch erkrankten Kühen die KBR nur 41 Tiere, der ELISA jedoch 106 Tiere detektieren konnte. Man hatte festgestellt, dass bei experimentell infizierten Tieren der ELISA 1-5 Monate früher detektieren konnte, und 7-10 Monate früher bei natürlich infizierten Tieren. Diese Angaben verdeutlichen die Schwächen der KBR (232).

Für die Paratuberkulose-Diagnostik wurden die vier serologischen Test-Methoden KBR, AGIDT, Allied ELISA sowie CSL ELISA evaluiert. Es wurden insgesamt 177 subklinisch an Paratuberkulose erkrankte Rinder untersucht. Von 177 Tieren waren 108 Tiere kotkulturell positiv und 69 Tiere waren kotkulturell negativ. Die serologischen Untersuchungen der 177 Tiere mit KBR, AGIDT, Allied ELISA und CSL ELISA ergaben eine 38,4\%, 26,6\%, 58,8\% und 43,4\% ige Sensitivität sowie eine 99,0\%, 100,0\%, 95,4\%, 99,0\%-ige Spezifität. Als man die 108 in der Fäkal-Kultur positiven Tiere mit KBR, AGIDT, Allied ELISA und CSL ELISA untersuchte, konnte man nur 54,6\%, 40,7\%, 65,7\% und 56,5\% positive Tiere detektieren und von den 69 subklinisch kranken, aber kotkulturell negativen Tieren waren nur 14,5\%, 4,3\%, $47,8 \%$ und $24,6 \%$ Tiere positiv. Somit ist ersichtlich, dass die KBR allein für die Sanierung mit Paratuberkulose infizierter Betriebe nicht ausreichend ist (184).

Um die Zuverlässigkeit verschiedener serologischer Nachweisverfahren bei der Paratuberkulose zu vergleichen, wurden die Komplementbindungsreaktion (KBR), der Gel-Diffusionstest (GDT), ein kommerzieller ELISA und ein selbst entwickelter ELISA verglichen. Untersucht wurden zwei paratuberkulosefreie Herden mit insgesamt 253 Schafen und zwei von Paratuberkulose betroffene Herden mit insgesamt 103 Schafen. Die Untersuchungen ergaben, dass die Spezifität bei allen serologischen Nachweisverfahren 97\% betrug und die Sensitivität bei histopathologisch positiven Tieren $98 \%$ betrug. Die vorhandenen serologischen Tests, die momentan zur Verfügung stehen, sind ohne kulturellen Nachweis des Erregers aus Kot für die Kontrolle und Sanierung von betroffenen Betriebe nur begrenzt brauchbar (86).

Um die Sensitivität und Spezifität verschiedener serologischer Tests (KBR, kommerzieller ELISA, lokal produzierter ELISA) zu evaluieren, wurden sie mit der Kotkultur verglichen. Die serologischen Untersuchungen von 106 kotkulturell positiven Tieren ergab für den lokal verwendeten ELISA 47,2\%, den kommerziellen ELISA 31,1\% und KBR 17,9\%-ige Sensitivität. Die Sensitivität betrug 87,5\%, 75,0\% und 56,3\% bei hoch ausscheidenden (über 100 Kolonien) Tieren. Nach der Untersuchung von 341 negativen Tieren wurde eine Spezifität von 
99,7\%, 97,9\% und 97,1\% festgestellt. Die Untersuchungen zeigen, dass die ELISA-Methode sensitiver ist als die KBR-Methode, deshalb sollte der ELISA anstelle der KBR im internationalen Handel und für die Sanierung der Paratuberkulose eingesetzt werden (158).

\subsection{Enzyme-Linked Immunosorbent Assay (ELISA)}

Der Enzyme Linked Immuno Sorbent Assay (ELISA) wurde zur serologischen Diagnostik der Paratuberkulose von Jorgensen und Jensen eingeführt (99). In den letzten Jahren wurden einige unterschiedliche ELISA-Verfahren entwickelt. Gemeinsam ist diesen Tests die indirekte ELISA-Technik zum Nachweis von Antikörpern gegen MAP (99).

Viele der Tests weisen eine zu geringe Sensitivität und Spezifität für die Detektion subklinisch erkrankter Tiere auf $(11,45)$. Die beschriebenen ELISA-Methoden unterscheiden sich hinsichtlich Präparation und Qualität des verwendeten Antigens. So reinigte Yokomizo ein Antigen auf, das vorwiegend Antikörper vom Typ IgG 1 nachweisen sollte. Die Präparationsschritte, die sich aus French-Press-Aufschluss, Zentrifugation, Dialyse und Filtration zusammensetzten, sowie die Behandlung der Patientenseren mit Kaolin, sollten unspezifische Reaktionen verringern. Für diesen ELISA wurde eine Sensitivität von 58\% und eine Spezifität von 97\% berechnet (233). Durch die Präadsorption der diagnostischen Seren mit einer Suspension von M. phlei konnte die Spezifität weiter erhöht werden (234). In einem weiteren ELISA, bei dem die Seren ebenfalls mit M. phlei absorbiert wurden, wurde eine Sensitivität von $57 \%$ und eine Spezifität von 98,9\% erreicht (131). Für einen ELISA ohne Präabsorption mit M. phlei wurde eine Sensitivität von 50,9\% und eine Spezifität von 94,9\% ermittelt (44). Hilbink zeigte jedoch, dass die Präabsorption von Seren mit M. phlei keine wesentlichen Vorteile erbringt (86). Bei dem vom United States Department of Agriculture (USDA) zugelassenen IDEXXELISA wurde eine Sensitivität von 56,5\% und eine Spezifität von 99,7\% berechnet (43). Auch bei dieser ELISA-Technik werden die zu untersuchenden Seren vor ihrem Einsatz im Test mit einer Ganzzell-Suspension von M. phlei behandelt. In anderen Arbeiten wurden ein Lipoarabinomannan (LAM), ein lipidfreies Arabinomannan, ein gereinigtes Protein sowie ein rekombinantes spezifisches Polypeptid als Antigen beschrieben $(55,197)$. Das LAM ist ein zellwandständiger Bestandteil der Mycobakterien. LAM und andere Zellwandbestandteile sind vermutlich wichtige Virulenzfaktoren pathogener Mycobakterien (16). Dieses LAM wurde von mehreren Forschern (197-199) im ELISA eingesetzt. Yokomizo verwendeten ein ungereinigtes protoplasmatisches Antigen für den von ihnen durchgeführten ELISA. Die von $(39,197,232)$ in ihren Arbeiten eingesetzten Antigene wurden aus dem vermeintlichen MAP- 
Stamm 18 isoliert. Molekularbiologische Untersuchungen dieses Stammes mittels PCR zeigten jedoch, dass es sich bei dem Stamm um einen M. avium-Stamm handelte, da die IS 900 nicht nachgewiesen werden konnte. Dieser Stamm, der seit 1920 in einigen Instituten der USA zur Herstellung von Antigenen, Vakzinen und Mycobactin genutzt wird, zeichnet sich durch ein schnelles Wachstumsverhalten in Kultur aus. Möglicherweise handelt es sich bei diesem Stamm um eine mehr als fünfzig Jahre alte Laborkontamination. Aus den genannten Gründen wird es für notwendig erachtet, den Stamm als M. avium Stamm 18 zu bezeichnen (25, 222). Um die Sensitivität eines Paratuberkulose-ELISA zu erhöhen, ist MAP mit molekularbiologischen und gentechnologischen Verfahren näher untersucht worden. Es konnte ein immunogenes 34-kDa-Protein isoliert und kloniert werden. Bei Einsatz dieses rekombinanten Polypeptids im Test zeigte sich, dass Kreuzreaktionen mit $M$. bovis und dem nahe verwandten M. avium deutlich reduziert werden konnten (55). Dieses rekombinante Polypeptid wurde als Antigen in einem anderen ELISA-System eingesetzt. Für diesen Test konnte eine Sensitivität von $70 \%$ und eine Spezifität von $95 \%$ berechnet werden (214). Ein Dot-ELISA, mit dem Rinderherden im US-Bundesstaat Ohio untersucht werden, weist eine Sensitivität von $85 \%$ und eine Spezifität von $100 \%$ auf (231).

Um chronische Infektionen von akuten Infektionen unterscheiden zu können, wird in der Humanmedizin ein Affinitäts-ELISA eingesetzt. Besonders Antikörper der Klasse IgG haben bei dieser ELISA-Technik eine wichtige Funktion.

Es wurde der Mycobacterium paratuberculosis Stamm JTC-303, welcher aus dem Ileum eines Holstein-Bullen isoliert wurde, kulturell angezüchtet. Das Antigen wurde im Anfangsstadium der im Wachstum befindlichen MAP Kultur isoliert und ein ELISA für die Paratuberkulosediagnostik entwickelt. Der ELISA wurde mit Hilfe von 444 Seren von an Paratuberkulose erkrankten Tieren und 412 Kontrollseren evaluiert. Die Sensitivität des JTC-ELISAs betrug 40\%, die Spezifität 99\%. Der JTC-ELISA wurde mit 4 weiteren im Handel erhältlichen ELISAs (IDEXX, CSL Prionics, Pourquier, Antel) verglichen. Die Untersuchungen zeigten, dass der JTC-ELISA in der Lage war, auch die Tiere zu detektieren, die MAP in geringen Mengen ausschieden (180).

Es wurde ein hochsensitiver und hochspezifischer Ethanol Vortex ELISA (EVELISA) für die Paratuberkulosediagnostik entwickelt. Als Antigene dienten MAP-Oberflächenepitope. Die Sensitivität des EVELISA betrug 100\%, die Spezifität 97,4\% (62).

Für die serologischen Untersuchungen auf Paratuberkulose wird der ELISA regelmäßig eingesetzt, obwohl die durchschnittliche Sensitivität bei subklinisch erkrankten Tieren nicht besonders hoch ist. Die Spezifität wurde als ausreichend erachtet, da der ELISA mit M. phlei 
vorinkubiert sei $(160,232)$. Es wurde vermutet, dass die Präadsorption mit M. phlei kreuzreagierende Antikörper des MAC-Komplexes entfernt, wodurch die Spezifität erhöht wird. Die Untersuchungen zeigten, dass ein mit M. phlei vorinkubiertes kommerzielles ELISA-Kit MAP nicht von $M$. bovis unterscheiden konnte, obwohl die Tiere künstlich infiziert waren und einen höheren Antikörpertiter aufwiesen (142).

Zur Zeit auf dem Markt befindliche ELISAs besitzen niedrige Sensitivitäten und zeigen Kreuzreaktionen mit Antikörpern gegen andere Mycobacterien als MAP (81).

Untersuchungen ergaben, dass der Allied ELISA eine Sensitivität von 58,8\% und eine Spezifität von 95,4\% aufwies und der CSL ELISA eine Sensitivität von 43,4\% und eine Spezifität von $99,0 \%$ besaß (184).

Um Sensitivität und Spezifität eines komerziellen ELISAs evaluieren zu können, wurde eine große Anzahl von Tieren auf Paratuberkulose untersucht. Die Untersuchungen bestätigten die vom Hersteller angegebe Spezifität von 99\% (203).

Es wurde der Wallaceville Animal Health Laboratory absorbed ELISA (W-ELISA), der geringfügig modifiziert war, mit dem C-ELISA der Commonwealth Serum Laboratories verglichen. Die Untersuchungen ergaben, dass der W-ELISA eine Sensitivität von 47,2\% und eine Spezifität von 99,7\% aufwies. Der S-ELISA wies hingegen eine Sensitivität von $31,1 \%$ und eine Spezifität von 97,9\% auf. Je mehr die Tiere den Paratuberkuloseerreger mit dem Kot ausschieden, desto höher war die Sensitivität der ELISAs (158).

Zwei auf dem Markt befindliche ELISAs, die für die Paratuberkulosediagnostik genutzt werden, wurden mit der KBR verglichen. Die beiden ELISAs stammten von demselben Hersteller. Die Untersuchungen zeigten, dass einer der ELISAs eine Sensitivität von 29,8\% und eine Spezifität von 99,8\% und der zweite ELISA eine Sensitivität von 39,4\% und eine Spezifität von 97,0\% aufwies. Die Sensitivität der KBR betrug 35,4\%, die Spezifität 62-100\%. Die Sensitivität stieg bei allen drei Tests kontinuierlich mit der Menge des im Kot ausgeschiedenen MAP Erregers an (101).

Um die Paratuberkulosediagnostik beim Rothirsch zu erleichtern, wurde ein ELISA entwickelt. Als Antigen wurde „denaturated purified protein derivate“ (PPDj) und „undenaturated protoplastic Antigen“" (PpAg)“ verwendet. Diese Antigene sind hochreaktiv gegen den IgG1 Isotyp, welcher als hochspezifischer Marker gegen Paratuberkulose beim Hirsch galt. Der ImmunoglobulinG1-ELISA wies eine Sensitivität von 91,0\% und eine Spezifität von 99,5\% auf (76).

Um Paratuberkulose bei Ziegen effektiver diagnostizieren zu können, wurde ein kommerziell erhältlicher Rinder-ELISA für die Diagnostik bei Ziegen angepasst. Sowohl der Serum- als 
auch der Milch-ELISA waren mit M. phlei adsorbiert worden. Die Sensitivität des ELISA bei Ziegenseren betrug 64\%, die Sensitivität des Milch-ELISAs 48\%. Die ELISA-Spezifität lag sowohl im Serum als auch in der Milch bei 100\% (168).

Um die Sensitivität und Spezifität verschiedener ELISAs vergleichen zu können, wurden fünf ELISAs evaluiert. Drei ELISAs (zwei für Serum und einer für Milch) hatten eine Spezifität von $99,8 \%$, die Spezifitäten der anderen beiden ELISAs, beide für Serum, betrugen 94,9\% bzw. 84,7\%. Beim Untersuchen kulturpositiver Kotproben wurde festgestellt, dass vier der fünf ELISAs eine Sensitivität von 27,8-28,9\% aufwiesen. Der ELISA „D“ besaß die niedrigste Spezifität, jedoch die höchste Sensitivität mit 44,5\%. Die Untersuchungen zeigten, dass ein direkter Zusammenhang zwischen der ausgeschiedenen Menge an MAP-Erregern und den ELISA Ergebnissen besteht. Für die endgültige Diagnose bleibt jedoch die kulturelle Untersuchung ausschlaggebend (168).

Für die Entwicklung eines ELISA wurden MAP-Bakterien mit Formaldehyd behandelt und für 2 sec. beschallt. Anschließend wurden durch Zentrifugation Oberflächenantigene isoliert. Mit diesen Oberflächenantigenen wurden die in der Diagnostik eingesetzten Mikrotiterplatten beschichtet. Diese Untersuchungen zeigten, dass dieser ELISA eine Sensitivität von 95,6\% besaß und von 23 kulturell-positiven Tieren 22 als positiv identifizieren konnte. Der mit Formaldehyd behandelte und beschallte MAP-Antigen-ELISA ist subspeziesspezifisch und ruft keine Kreuzreaktionen mit anderen M. avium Subspezies hervor. Dieser ELISA ist sehr sensitiv und detektiert sogar subklinisch erkrankte Tiere, welche MAP-Erreger in geringen Mengen ausscheiden (186).

Für die Entwicklung eines weiteren ELISAs wurden MAP-Bakterien mit 80\%igem Ethanol behandelt und für $30 \mathrm{sec}$. auf einem Vortex-Schüttler inkubiert, anschließend wurden durch Zentrifugation die Oberflächenantigene isoliert. Die mit dem Oberflächenantigen beschichteten Platten wurden für die Paratuberkuloseuntersuchung eingesetzt. Die Untersuchungen zeigten, dass dieser ELISA eine Sensitivität von 97,4\% und eine Spezifität von 100\% besaß.

Der mit Ethanol behandelte MAP-Antigen-ELISA ist subspeziesspezifisch und ruft keine Kreuzreakzionen mit anderen M. avium Subspezies hervor. Dieser ELISA ist sehr sensitiv und erkennt nicht nur Tiere, die den MAP-Erreger in großen Mengen mit dem Kot ausscheiden, sondern auch Tiere, welche geringe Konzentrationen ausscheiden (62).

Es war bekannt, dass die Proteine, welche serodiagnostisches Potenzial besitzen, im Filtrat von Kulturmedium in höherer Konzentration vorhanden sind als im zellulären Extrakt von MAP-Flüssigmedium. Basierend auf diesen Erkenntnissen wurden Antigene des JTC 303 Stamms, welcher auf dem Watson-Reid Medium kultiviert wurde, in einer frühen Wachs- 
tumsphase isoliert. Nach Zentrifugation und Filtration wurden die ELISA-Platten mit dem Antigen beschichtet und für die Paratuberkulosediagnostik eingesetzt. Die Untersuchungen zeigten, dass der ELISA eine Sensitivität von 74\% und eine Spezifität von 99,0\% besaß (180).

\subsubsection{Allergologische Verfahren}

Allergologische Verfahren wurden schon frühzeitig als Diagnoseverfahren zum Nachweis der Paratuberkulose bei Rindern eingesetzt. Die ersten Versuche wurden mit Geflügeltuberkulin durchgeführt $(7,89)$. Die subkutane Injektion von aviärem Tuberkulin bei infizierten Rindern führte zu einem deutlichen Anstieg der Temperatur, was bei Verwendung von bovinem Tuberkulin ausblieb.

Die intrakutane Injektion von $0,1 \mathrm{ml}$ Johnin seitlich am Hals kann bei einem sensibilisierten Tier zwei unterschiedliche Reaktionen auslösen. Eine allergische Reaktion vom Soforttyp verursacht innerhalb von 2 Stunden eine ödematöse Schwellung im Bereich der Injektionsstelle. Diese als unspezifisch zu bewertende Reaktion wird aufgrund einer Sensibilisierung gegenüber anderen Mykobakterien ausgelöst. Als spezifisch gilt die allergische Reaktion vom Spättyp, bei der es innerhalb von 24-72 Stunden nach der Johnin-Applikation zur Umfangsvermehrung an der Injektionsstelle kommt. Außerdem kommt es zu einer Erhöhung der Hauttemperatur (121). Die allergische Reaktion kann auch bei intravenöser Injektion von 2-4 ml Johnin durchgeführt werden. Danach kommt es im positiven Fall zu einer Erhöhung der Körpertemperatur um mindestens $0,8{ }^{\circ} \mathrm{C}$ auf mindestens $39,5{ }^{\circ} \mathrm{C}$ sowie einem Anstieg der neutrophilen Granulozyten bei gleichzeitiger Abnahme der Lymphozyten im Blutbild. Der intravenöse Allergietest besitzt eine höhere Genauigkeit als der Intrakutantest, dafür wird aber erheblich mehr Johnin (2-4 ml) verbraucht, und bei einigen infizierten Tieren kann ein anaphylaktischer Schock auftreten (32).

Um die benötigte intravenöse Injektionsmenge (1,6 und 3,2 ml) für Johnin bestimmen zu können, wurden 116 Rinder untersucht. Nach intravenöser Injektion wurde bei den Tieren ein Temperaturanstieg von $1,47^{\circ} \mathrm{C}$ gemessen, unabhängig von der Injektionsmenge. Die Sensitivität dieser Untersuchungsmethode betrug $84 \%$ bei klinisch erkrankten Tieren (14).

Um Sensitivität und Spezifität des Johnin-Hauttest bei Schafen bestimmen zu können, wurden entsprechende Untersuchungen durchgeführt. Hautverdickungen von mehr als $2 \mathrm{~mm}$ wurden als positiv betrachtet. Zur Bestimmung von Sensitivität und Spezifität wurden histopathologische Befunde als Referenzen benutzt. Die Untersuchungen haben gezeigt, dass der JohninHauttest eine Sensitivität von 55,6\% und eine Spezifität von 100\% besitzt (152). 
In einer Vergleichsuntersuchung wurden 43 mit Paratuberkulose infizierte Ziegen untersucht. Die histologische Gewebeuntersuchung zeigte, dass bei allen Tieren typische entzündliche Veränderungen vorhanden waren. Diese Veränderungen wurden entweder der paucibacillären oder multibacillären Form zugeordnet. Die Sensitivität von Johnin-Test, Gewebekultur, Fäkalkultur, Gewebe-PCR, AGIDT und ELISA waren 68\%, 100\%, 84,6\%, 100\%, 96,2\% bzw. $100 \%$ bei der multibacillären Form und 88,8\%, 46,1\%, 40\%, 61,5\%, 50\% bzw. 70\% bei der pauzibacillären Form. Der Johnin-Test zeigte eine hohe Sensitivität für die pauzibacilläre Form, die restlichen Tests eine hohe Sensitivität bei der multibacillären Form der Infektion. Die Ergebnisse zeigen, dass der Johnin-Test die Tiere detektiert, die im Anfangsstadium der Infektion sind. Die anderen Tests weisen Tiere nach, die sich bereits im klinischen Stadium befinden (207).

Um Sensitivität und Spezifität von AGIDT, Johnin-Hauttest und ELISA bei Schafen vergleichen zu können, wurde die Methode nach Bayes ohne Goldstandard angewendet. Es wurden insgesamt 14 Herden (2465 Schafe) untersucht. Die Untersuchungen zeigten, dass der JohninHauttest in nicht infizierten Herden spezifisch genug war. In infizierten Herden zeigte der Johnin-Test die höchste Sensitivität. AGIDT und ELISA besaßen ausreichende Spezifität, jedoch geringe Sensitivität (164). 
In den letzten Jahrzehnten hat die Paratuberkulose eine große Bedeutung erlangt, da sie in vielen Ländern auftritt und große wirtschaftliche Schäden in den Milchviehbeständen in vielen Industrieländern verursacht. Außerdem besteht der Verdacht, dass MAP die Krankheit Morbus Crohn beim Menschen hervorruft. Die grenzüberschreitenden Tierverkäufe haben dazu beigetragen, dass sich diese Krankheit in vielen Ländern schnell verbreitet. Die Paratuberkulose ist dabei besonders in Milchviehbeständen weit verbreitet.

Von der Paratuberkulose sind in Deutschland immer mehr Rinderbestände betroffen. Die Erfahrungen anderer Länder zeigten, dass die Bekämpfungsprogramme über mehrere Jahre andauern können, enorm kostspielig sind und meistens nicht zum gewünschten Ziel führen. Obwohl die Paratuberkulose auch in Deutschland beachtliche wirtschaftliche Schäden verursacht, sind nicht alle Betriebe in Niedersachsen bereit, am freiwilligen Bekämpfungsprogramm der niedersächsischen Tierseuchenkasse teilzunehmen.

Mit dieser Arbeit wird versucht, über Kontrolluntersuchungen Erkenntnisse zu gewinnen, ob der Infektionsdruck in den Betrieben mit Hilfe regelmäßiger serologischer Untersuchungen, rechtzeitiger (innerhalb von 6 Wochen nach Mitteilung des positiven Befundes) Entfernung reagierender Tiere und der Einhaltung von Hygienemaßnahmen gesenkt werden kann, um diese allmählich zu sanieren.

Dafür wurde in einem ausgewählten Betrieb, welcher bereit war, an dem Niedersächsischen Bekämpfungsprogramm teilzunehmen, Kontrolluntersuchungen durchgeführt. Außerdem wurde in diesem Betrieb versucht, die vorgeschriebenen Management und Hygienemaßnahmen durchzuführen. Für die serologischen Untersuchungen wurden zwei verschiedene ELISA-Systeme (IDEXX-und Svanovir ELISA) verwendet, welche in Deutschland zugelassen waren.

In dieser Arbeit werden die Ergebnisse der Paratuberkuloseuntersuchungen, die über acht Jahre durchgeführt wurden, ausgewertet und der Erfolg der Sanierung diskutiert. 
AGIDT

Aqua dest.

$\mathrm{Bp}$

CMI

CWD

DNS

ELISA

FRET

HRPO

IFN

IG

IS

KBR

KBE

KD

LAM

MAC

Min

M

$\mu 1$

$\mathrm{ml}$

$\mu \mathrm{m}$

MAP

$\mathrm{Nm}$

OD

PBS

PCR

RT

$\mathrm{U} / \mathrm{M}$

USDA
Agargelimmundiffusionstest

Destilliertes Wasser

Basenpaar

Zellmediierte Immunantwort

Cell-Wall Deficient

Desoxyribonukleinsäure

Enzyme Linked Immuno Sorbent Assay

Fluorescence Resonance Energy Transfer

Horseradish Peroxidase

Interferon

Immunglobulin

Insertionssequenz

Komplementbindungsreaktion

Kolonie bildende Einheiten

Kilodalton

Lipoarabinomannan

Mycobacterium Avium Complex

Minuten

Molar

Microliter

Milliliter

Micrometer

Mycobacterium avium subspecies paratuberculosis

Nanometer

Optische Dichte

Phosphat buffered Saline

Polymerase-kettenreaktion

Raumtemperatur

Umdrehungen pro minute

US Department of Agriculture 
Im Rahmen dieser Arbeit wurden in einem Betrieb im Landkreis Göttingen Blutproben von Rindern entnommen und serologisch auf Paratuberkulose untersucht. Es handelt sich um einen reinen Milchviehbetrieb, in dem die Tiere in verschiedenen Haltungssystemen gehalten werden (Milchkühe auf Spaltenboden und Jungtiere im Boxenlaufstall oder in Anbindehaltung). In diesem Betrieb werden die Rinder bis zu einem Alter von drei Monaten als Kälber bezeichnet. Als Jungtiere gelten weibliche Rinder vom vierten Lebensmonat bis zu ihrer ersten Kalbung, danach werden sie zu den Kühen gerechnet. Im Jahre 2000 faßte der Betrieb „H“ im Landkreis Göttingen den Entschluß, an einer diagnostischen Kontrolluntersuchung für Paratuberkulose teilzunehmen. Er hatte sich ferner vorgenommen, die Reagenten fristgerecht, innerhalb von 6 Wochen nach Mitteilung des positiven Befundes, auszumerzen.

\subsection{2}

Betriebsstruktur und Hygienemaßnahmen des untersuchten Bestandes

Die Milchkühe sind an Standort 1 stationiert, während die Kälber und Jungtiere bis vier Wochen vor dem ersten Abkalben im Standort 2 und Standort 3 untergebracht sind. Die Entfernung des Standorts 2 vom Standort 1 beträgt $25 \mathrm{~km}$, die des Standorts 3 zum Standort 1 beträgt $4 \mathrm{~km}$. Die Versorgung der verschiedenen Standorte wurde so organisiert, dass Kontakte von Milchkühen und Jungtieren vermieden werden. Diese hygienische Maßnahme ist eine der Voraussetzungen für die Bekämpfung der Paratuberkulose, um die mögliche Ansteckung der Jungtiere zu vermeiden.

In diesem Betrieb wurden die Kühe in einen Boxenlaufstall mit Spaltenboden eingestellt. Die Jungtiere wurden im Boxenlaufstall und in Anbindehaltung gehalten. Die Abkalbung der trächtigen Kühe erfolgte in getrennten Abkalberäumen. Nach der Geburt wurden die Kälber sofort von ihren Müttern getrennt und in Kälberboxen verbracht. Vor der Kolostrumgewinnung wurde das Euter gründlich gereinigt. Die Kälber erhielten in der Regel 14 Tage lang die Kolostralmilch ihrer Mütter. Wenn die Mutterkühe klinische Anzeichen der Paratuberkulose oder positive Untersuchungsergebnisse aufwiesen, wurden die Kälber mit zuvor von negativ getesteten Müttern gewonnener und dann tiefgefrorener Kolostralmilch sowie mit Milchaustauscher gefüttert. Dann wurden die Kälber zu den Tränkeautomaten gebracht, die sie bis zum dritten Lebensmonat benutzten. Im Alter von drei Monaten wurden die Tiere zu den Standorten 2 oder 3 transferiert, wo sie im Boxenlaufstall untergebracht wurden. Im Alter von sechs 
Monaten wurden die Tiere im Standort 3 in Anbindehaltung und im Standort 2 auf Spaltenboden mit Liegeboxen gehalten. Von den Standorten 2 und 3 wurden die Tiere vier bis sechs Wochen vor der Abkalbung zum Standort 1 zurückgebracht. Die anfallende Gülle wurde nicht auf den Weiden, sondern nur auf Ackerflächen ausgebracht. Während der Versuchsphase wurden nur im Jahre 2001 Rinder zugekauft. Ältere und jüngere Tiere hatten keinen Kontakt zueinander und benutzten keine gemeinsamen Weiden.

Obwohl die Kühe und Kälber in gesonderten Ställen untergebracht waren, wurden bei der Betreuung der Tiere dieselben Geräte eingesetzt und es gab kein getrenntes Schuhwerk bzw. Kleidung. Obwohl ein Abkalberaum vorhanden war, wurde dieser nicht ausschließlich zum Kalben benutzt, sondern gelegentlich auch zur Absonderung lahmer und kranker Tiere. Vor der Abkalbung wurden Boden und Wände des Abkalberaums nicht besonders gereinigt, der Boden des Abkalberaums wurde jedoch mit einer dicken sauberen Strohschicht eingestreut. Obwohl bei der Kälberaufzucht auf Hygiene besonderen Wert gelegt wurde, gelang es trotzdem nicht, alle Hygienemaßnahmen konsequent einzuhalten. Die Kälber wurden z.B. mit Silage von Feldern gefüttert, auf denen vorher die betriebseigene Gülle ausgebracht worden war.

\subsection{3}

\section{Probenentnahme im Betrieb}

Im Betrieb „H“ wurden Blutproben entnommen. Die Blutgewinnung erfolgte durch Punktion der Schwanzvene (V. coccygea media) oder durch Punktion der Drosselvene (V. jugularis). Als Probenbehältnisse dienten Serumröhrchen (KABE Labortechnik GmbH, 51588 Nümbrecht-Elsenroth Deutschland). Die Blutproben wurden vom zuständigen Haustierarzt entnommen und für die weitere Untersuchung an das Tierärztliche Institut der Georg-AugustUniversität Göttingen gesandt. Hier erfolgte die Serumgewinnung durch Zentrifugation der Blutproben für $10 \mathrm{~min}$. bei $3000 \mathrm{U} / \mathrm{min}$. Zur Aufbewahrung der diagnostischen Seren wurden diese bei $-20{ }^{\circ} \mathrm{C}$ eingefroren.

Die Kotproben wurden von jedem Tier einzeln mit einem sterilen Besamungshandschuh rektal entnommen und in sterile $100 \mathrm{ml}$ Becher (Sarstedt) gegeben. Diese wurden mit einem Deckel fest verschlossen, mit Nummer versehen und für die weitere Untersuchung an das Tierärztliche Institut der Georg-August-Universität Göttingen gesandt. Für die Untersuchung wurden Pools aus jeweils 10 Tieren gebildet. Dafür wurde von jeder Probe 1 g Kot genommen und in einen Becher zum Mischen gegeben. 
Der ELISA ist eine biochemische Technik, welche hauptsächlich in der Immunologie verwendet wird, um in Proben die Anwesenheit von Antigen oder Antikörper nachzuweisen.

Das Prinzip der ELISA-Methode beruht auf der unspezifischen physikalischen Adsorbtion von Antigenen oder Antikörpern an Kunstoffoberflächen und der spezifischen Bindung von enzymmarkierten Antikörpern an das adsorbierte Antigen. Die für die ParatuberkuloseDiagnostik verwendeten Svanovir-und IDEXX-ELISAs werden zum Nachweis von Antikörpern benutzt.

\subsection{SVANOVIR-ELISA}

\section{$\underline{\text { Material }}$}

- Mikrotiterplatten, monophasisch beschichtet mit nicht infektiösem Paratuberkulose-Antigen (Lipoarabinomannan). Nunc-Immuno ${ }^{\mathrm{TM}}$ Platte Poly Sorp ${ }^{\mathrm{TM}}$ Oberfläche (Nunc- Gmbh \& Co.KG, Wiesbaden)

- Waschlösung PBS-Tween-Lösung, 20-fach konzentriert

- Verdünner: Waschlösung, gebrauchsfertig

- Anti-Rind-IgG-HRP-Konjugat, lyophilisiert

- Substratlösung (Tetramethyl-benzidin und $\mathrm{H}_{2} \mathrm{O}_{2}$, gelöst in Substratpuffer)

- Stopplösung (2M Schwefelsäure)

- Positive Serumreferenz (Positivkontrolle)

- Negative Serumreferenz (Negativkontrolle)

- Proben: Blutseren

Das nachfolgend beschriebene Testsystem wurde von der Firma SVANOVA Biotech AB, Uppsala Science Park, SE-75183 Uppsala Schweden hergestellt und nach Herstelleranleitung in der vorliegenden Arbeit für den Nachweis von MAP verwendet.

Der SVANOVIRTM Para-TBC-Antikörper-Test ist ein ELISA zum spezifischen Nachweis von Antikörpern gegen MAP im Blutserum bzw. Plasma und Milch von Rindern.

Die Mikrotiterplatten sind mit Antigen beschichtet. Die vorverdünnten Referenzseren und Proben wurden in die Vertiefungen der Mikrotiterplatten gegeben. In den Seren vorhandene Antikörper binden an in den Reaktionsvertiefungen (wells) fixiertes Antigen, ungebundenes überschüssiges Material wird durch Waschen entfernt.

Anschließend werden die gebundenen Antikörper mit Meerrettichperoxidase-HRPO-Protein Immunglobulin G-Konjugat nachgewiesen, das bovine Immunglobuline spezifisch erkennt und mit bereits an der Mikrotiterplatte gebundenen Antikörpern reagiert. Nach Substratzugabe kommt es zu einer Farbreaktion, die durch Zugabe der Stopplösung beendet wird. Wenn in 
der $\mathrm{zu}$ testenden Probe keine messbaren Antikörper gegen MAP vorhanden sind, kann das zugegebene HRPO-Konjugat nicht binden und wurde beim vorhergehenden Waschvorgang entfernt. Ist kein Enzym-gekoppeltes Konjugat gebunden, kann auch das abschließend zugegebene Substrat nicht umgesetzt werden, die Farbreaktion bleibt aus, der Test ist negativ. Die Farbreaktion wird mit einem Photometer (SLT Spectra II, SLT Labinstruments Crailsheim) bei einer einfachen Wellenlänge von $450 \mathrm{~nm}$ und einer Referenzwellenlänge von $492 \mathrm{~nm}$ gemessen. Das Ergebnis wird berechnet, indem die optische Dichte (OD-Wert) der positiven Serumreferenz und der OD-Wert der Probe um den OD-Wert der negativen Serumreferenz korrigiert werden und anschließend das Verhältnis der Probe zur positiven Serumreferenz berechnet wird.

\section{$\underline{\text { Vorbereitung der Serumproben und Testablauf }}$}

Für die Durchführung des Tests wurden von den zu untersuchenden Tieren Blutproben genommen und daraus durch Zentrifugieren $\left(\right.$ Beckman $^{\circledR}$ Model TJ-6 Centrifuge USA) bei $3000 \mathrm{U} / \mathrm{min}$ für $10 \mathrm{~min}$ Blutserum gewonnen. Sowohl das Serum als auch die positive und die negative Serumreferenz wurden 1: 100 verdünnt.

Dann wurden mit Antigen beschichtete Mikrotiterplatten genommen und in die Vertiefungen A1/F1 $100 \mu 1$ der positiven Serumreferenz im doppelten Ansatz und in die Vertiefungen B1/H1 der doppelte Ansatz der negativen Serumreferenz gegeben. In die restlichen Vertiefungen wurden $100 \mu l$ der zu untersuchenden Serumproben gegeben. Die Platten wurden versiegelt und 30 min bei Raumtemperatur (RT) inkubiert. Anschließend wurden die Vertiefungen der Mikrotiterplatten geleert und mit Waschlösung 3 mal gewaschen und gut ausgeschlagen, nachfolgend wurde in jede Vertiefung $100 \mu 1$ Konjugatlösung zupipettiert und nach Versiegelung der Platten 30 min lang bei RT inkubiert. Danach wurden die Mikrotiterplatten wieder geleert und mit Waschpuffer 3 mal gewaschen und gut ausgeschlagen. Pro Kavität wurde $100 \mu 1$ TMB- Lösung (Substrat) zugegeben und nach der Versiegelung der Platten 10 min lang bei RT im Dunkeln inkubiert. In jede Kavität wurde anschließend $50 \mu 1$ Stopplösung zugegeben, um die Reaktion zu beenden.

Die Extinktion wurde bei einer Wellenlänge von $450 \mathrm{~nm}$ und einer Referenzwellenlänge von 492 nm gemessen (SLT Spectra II, SLT Labinstruments, Crailsheim). 
Mit Hilfe eines PC gestützten ELISA-Programmes wurden aus den gemessenen Extinktionen die ELISA-Einheiten (EU) gemäß der Referenz-Standard-Methode berechnet.

Das positive Kontrollserum stellt das Referenzserum dar, welches eine fiktive ELISAAktivität von $100 \%$ erhält. Die negative Kontrolle soll eine ELISA-Aktivität kleiner als 10\% aufweisen. Für die Bewertung der Patientenproben wird folgende Formel verwendet:

Probenwert $(\%)=\frac{\text { Optische Dichte }}{\text { Probe }}$

Das heißt, die optische Dichte der Probe wird dividiert durch den gemittelten Wert des Referenzserums (zwei positive Kontrollen) und der erhaltene Wert wird mit 100 multipliziert. Der sich ergebende Wert ist folglich der Prozentsatz der gemittelten positiven Kontrolle.

Für die Berücksichtigung der Ergebnisse gelten folgende Bereiche:

Negativer Bereich $\quad<31 \%$

Fraglicher Bereich $\quad 31-52 \%$

Positiver Bereich $\quad>52 \%$

\subsection{IDEXX-ELISA}

$\underline{\text { Material }}$

- Mikrotiterplatten: monophasisch mit MAP (inaktiviert) beschichtet.

Nunc-Immuno ${ }^{\mathrm{TM}}$ Platte Poly Sorp ${ }^{\mathrm{TM}}$ Oberfläche (Nunc Gmbh \& Co. KG. Wiesbaden)

- Waschlösung: 10x Konzentrat

- Absorbens Lösung

- Konjugat: 1: 100 mit PBS verdünnen

- Substrat: $\mathrm{TMB} / \mathrm{H}_{2} \mathrm{O}_{2}$

- Stopplösung: $1 \mathrm{M} \mathrm{HCI}$

- Positive Serumreferenz (Positivkontrolle)

- Negative Serumreferenz (Negativkontrolle)

- Proben: Blutseren

Das nachfolgend beschriebene Testsystem wurde von der Firma IDEXX Westbrook, Maine 04092, USA hergestellt und nach Herstelleranleitung verwendet.

Herd Chek* M. pt ist ein ELISA zum Nachweis von Antikörpern gegen MAP in Serum- und Plasmaproben von Wiederkäuern. Der Test ist ein indirekter ELISA, der in Mikrotiterplatten durchgeführt wird. Die Mikrotiterplatten bestehen aus Polysterol, welche mit MAP-Antigenen 
beschichtet werden. Die Platten werden mit Mycobacterium phlei-Extrakt inkubiert, um unspezifische Antikörper zu binden. Sowohl die vorinkubierten Seren als auch die positive und die negative Serumreferenz werden in die Vertiefungen der Mikrotiterplatten gegeben. In den Proben vorhandene Antikörper binden an in den Reaktionsvertiefungen (wells) fixiertes Antigen. Ungebundenes Material wird durch Waschen mit PBS entfernt. Anschließend werden die gebundenen Antikörper mit Meerrettichperoxydase-(HRPO)-Protein G Konjugat nachgewiesen. Es erkennt bovine Immunglobuline und reagiert mit bereits an der Mikrotiterplatte gebundenen Antikörpern. Ungebundenes, überschüssiges Material wird durch Waschen mit PBS entfernt. Nach Substratzugabe kommt es zu einer Farbreaktion, die durch Zugabe der Stopplösung beendet wird. Die Farbreaktion wird mit einem Photometer (SLT Spectra II, SLT Labinstruments, Crailsheim) bei einer einfachen Wellenlänge von $450 \mathrm{~nm}$ und einer Referenzwellenlänge von $620 \mathrm{~nm}$ gemessen. Das Ergebnis wird berechnet, indem der OD-Wert der Referenzseren und der OD-Wert der Probe um den OD-Wert der negativen Serumreferenz korrigiert werden und anschließend das Verhältnis der Probe zur positiven Serumreferenz berechnet wird.

\section{$\underline{\text { Vorbereitung von Serumproben und Testablauf }}$}

Für die Durchführung des Tests werden von den zu untersuchenden Tieren Blutproben genommen und davon durch Zentrifugieren Blutserum gewonnen. Das Serum sowie die positive Serumreferenz und die negative Serumreferenz werden 1:10 mit PBS verdünnt und 60 min bei RT inkubiert.

Danach werden mit Antigen beschichtete Mikrotiterplatten genommen und in die Vertiefungen A1/F1 je $100 \mu 1$ der positiven Serumreferenz und in die Vertiefungen B1/H1 $100 \mu 1$ der negativen Serumreferenz gegeben. In die restlichen Vertiefungen werden $100 \mu 1$ der zu untersuchenden Serumproben gegeben und die Platten versiegelt 60 min bei RT inkubiert. Anschließend werden die Vertiefungen der Mikrotiterplatten geleert und mit Waschlösung 5 mal gewaschen und gut ausgeschlagen. In jede Vertiefung wird $100 \mu 1$ Konjugatlösung pro Kavität pipettiert und nach Versiegelung der Platten 30 min lang bei RT inkubiert. Danach werden die Mikrotiterplatten wieder geleert und 5 mal gewaschen und gut ausgeschlagen. Anschließend werden pro Kavität $100 \mu \mathrm{l}$ Substrat zugegeben und nach Versiegelung der Platten 10 min lang bei RT im Dunkeln inkubiert. Danach wird in jede Kavität $100 \mu$ Stopplösung gegeben und die Reaktion beendet. Die Extinktion wird bei einer Wellenlänge von $450 \mathrm{~nm}$ 
und einer Referenzwellenlänge von $620 \mathrm{~nm}$ gemessen (SLT Spectra II, SLT Labinstruments, Crailsheim).

\section{$\underline{\text { Auswertung der IDEXX-ELISA-Testergebnisse }}$}

Mit Hilfe eines PC gestützten ELISA-Programmes wurden aus den gemessenen Extinktionen die ELISA-Einheiten (EU) gemäß der Referenz-Standard-Methode berechnet.

Für die Auswertung der Testergebnisse wird der Mittelwert der positiven Kontrolle berechnet und der Mittelwert der negativen Kontrolle berechnet.

Damit der Test valide ist, muss die Differenz zwischen dem Mittelwert der Positivkontrollen und dem Mittelwert der Negativkontrollen $\geq 0,15$ sein. Außerdem sollte die Extinktion der Negativkontrolle $\leq 0,2$ sein. Für die Auswertung der Proben wird von dem Extinktionswert der Probe der gemittelte Extinktionswert der Negativkontrolle abgezogen. Aus dem gemittelten Extinktionswert der Positivkontrolle wird ebenfalls der gemittelte Extinktionswert der Negativkontrolle abgezogen. Danach wird der erhaltene Extinktionswert der Probe durch den erhaltenen Extinktionswert der Positivkontrolle dividiert.

Die Testergebnisse werden mit Hilfe folgender Formel ausgewertet:

$\mathrm{S} / \mathrm{P}=\frac{\text { Sample } \mathrm{OD}_{450 \mathrm{~nm}}-\text { negative Serumreferenz } \mathrm{OD}_{450 \mathrm{~nm}}}{\text { Ø positiver Serumreferenz } \mathrm{OD}_{450 \mathrm{~nm}}-\text { negative Serumreferenz } \mathrm{OD}_{450 \mathrm{~nm}}}$

Für die Berücksichtigung der Ergebnisse gelten folgende Bereiche:

Negativer Bereich $\quad>0,15$

Fraglicher Bereich $\quad 0,15-0,30$

Positiver Bereich $>0,30$

\subsubsection{Molekulabiologische Methoden}

3.4.1.2.1 Erstellung der Pools

\section{$\underline{\text { Material }}$}

- PBS: $8,0 \mathrm{~g} \mathrm{NaCl}$ (Merck, Darmstadt)

$0,2 \mathrm{~g} \mathrm{KCl}$ (Merck, Darmstadt)

2,89 $\mathrm{g} \mathrm{Na}_{2} \mathrm{HPO} \times 12 \mathrm{H}_{2} \mathrm{O}$ (Merck, Darmstadt)

$0,2 \mathrm{~g} \mathrm{KH}_{2} \mathrm{PO}_{4}$ (Merck, Darmstadt)

ad $1000 \mathrm{ml}$ Aqua dest., $\mathrm{pH}$ 7,2 
Für die PCR-Untersuchung wurden Kotpools gebildet. Ein Kotpool bestand jeweils aus 10 Kotproben. Um eine möglichst flüssige Konsistenz und eine gute Durchmischung der Kotproben zu erreichen, wurden die Kotproben 1:1 mit PBS verdünnt. Die Probe wurde mit Hilfe eines Vortex-Gerät immer wieder gemischt und abwechselnd 3 mal mit dem „Bandelin Sonoplus-Gerät“ beschallt. Anschließend wurde aus jeder Kotprobe mit Hilfe einer Waage der Firma „Sartorius“ unter sterilen Bedingungen 1 Gramm Kot eingewogen und in ein steriles $50 \mathrm{ml}$ Falcon-Röhrchen gegeben. Die Proben wurden mit einem Vortex-Gerät noch 1 mal gemischt. Aus dieser Poolprobe wurden unter sterilen Bedingungen mit Hilfe einer Waage der Firma „Sartorius“ $50 \mathrm{mg}$ Kot abgewogen und in ein steriles 1,5 ml Eppendorf-Röhrchen gegeben. $\mathrm{Zu}$ der Kotprobe wurden $360 \mu$ Lysozym Puffer dazupipettiert, gut gemischt und $30 \mathrm{~min}$ bei $37^{\circ} \mathrm{C}$ und $900 \mathrm{U} / \mathrm{min}$ geschüttelt.

Zu der Probe wurde $40 \mu 1$ Proteinase K und $400 \mu 1$ Lysispuffer dazupipettiert, mit dem Vortex-Gerät gut gemischt und $30 \mathrm{~min}$ bei $56{ }^{\circ} \mathrm{C}$ inkubiert und anschließend noch mal 15 min bei $95{ }^{\circ} \mathrm{C}$ inkubiert. Danach wurde die Probe $1 \mathrm{~min}$ lang bei $13.000 \mathrm{U} / \mathrm{min}$ abzentrifugiert. Der Überstand wurde in ein neues steriles 1,5 ml Eppendorf-Röhrchen gegeben und die restlichen Kotpartikel verworfen. Es wurden $400 \mu 1$ 100\%-iger Ethanol dazupipettiert, gut gemischt und auf eine Anionenaustauschersäule pipettiert, die Säule anschließend verschlossen und $1 \mathrm{~min}$ lang bei $8000 \mathrm{U} / \mathrm{min}$ zentrifugiert.

Die Säule wurde dann auf ein neues sauberes Eppendorf-Röhrchen (2 $\mathrm{ml}$ ohne Deckel) gesteckt und $500 \mu \mathrm{l}$ AW1 Puffer darauf pipettiert, anschließend 3 min lang bei $13.000 \mathrm{U} / \mathrm{min}$ zentrifugiert und das alte Tube verworfen.

Die Säule wurde auf ein neues sauberes Eppendorf-Röhrchen (2 $\mathrm{ml}$ ohne Deckel) gesteckt und $500 \mu \mathrm{l}$ AW2 Puffer darauf pipettiert, anschließend $3 \mathrm{~min}$ lang bei $13.000 \mathrm{U} / \mathrm{min}$. zentrifugiert und das alte Tube verworfen.

Die Säule wurde auf ein neues sauberes Eppendorf Röhrchen ( $2 \mathrm{ml}$ ohne Deckel) gesteckt und nochmals $1 \mathrm{~min}$ bei $13.000 \mathrm{U} / \mathrm{min}$ zentrifugiert und wieder das alte Tube verworfen. Anschließend wurde die Säule auf ein sauberes 1,5 ml steriles Eppendorf Röhrchen gesteckt, $200 \mu 185^{\circ} \mathrm{C}$ warmer AE Puffer auf die Säule gegeben und nach 1 min Inkubationszeit für $1 \mathrm{~min}$ bei $8000 \mathrm{U} / \mathrm{min}$ abzentrifugiert. Das Eluat wurde beschriftet und für weitere Untersuchungen kühl gelagert. 


\subsection{Erregernachweis mittels PCR (MAP IS-900)}

Für die „seminested“-PCR wurden folgende Primer nach Schneider (2003) verwendet:

Primer Ptb1 for:

5'-GTCGGCGTGGTCGTCTGCTGGGTTGAT-3'

Primer Ptb1 rev:

5'-GCGCGGCACGGCTCTTGTTGTAGTC-3'

Primer Ptb2 for:

5'-CGGGCGCACGGTCCATCACG-3'

\section{Durchführung der ,,seminested“ PCR}

\section{$\underline{\text { Material }}$}

- Aqua dest.

- Ready-to-go ${ }^{\mathrm{TM}}$ PCR „Beads“ (Amersham Pharmacia Biotech, Freiburg)

- DMSO (Serva, Heidelberg)

- Primer (10 pmol) für die Amplifikation des 587 bp und des 278 bp Fragments: Ptb1 for, Ptb1 rev und Ptb2 for

Für den Ansatz der PCR wurden „Ready-To-Go ${ }^{\mathrm{TM}}$ “ $\mathrm{PCR}$ „Beads“ (Amersham Pharmacia Biotech, Freiburg) verwendet. Diese enthielten in lyophilisierter Form alle für einen $25 \mu 1$ PCR-Ansatz notwendigen Reagenzien wie Puffer, Nukleotide und Taq-DNS-Polymerase. Die einzelnen „Beads“ lagen in Form eines getrockneten Pellets in einem 0,5 ml Reaktionsgefäß vor und wurden bei Raumtemperatur gelagert.

Für den Reaktionsansatz wurde ein Mastermix aus Aqua dest., Primern und DMSO angesetzt und zu gleichen Teilen auf die Reaktionsgefäße mit den bereits vorhandenen „Beads“ verteilt. Als Template lag aus Rinderkot isolierte DNS vor, von der 2,5 $\mu 1$ eingesetzt wurden. Für die „seminested“-PCR wurden 2,5 $\mu$ d der ersten PCR als Template dem Reaktionsansatz hinzugefügt. Die Mischung des PCR-Ansatzes erfolgte bis zu diesem Schritt auf Eis gekühlt. Die Proben wurden anschließend in einen Thermocycler (Gene Amp ${ }^{\circledR}$ PCR-System 9700, PE Applied Biosystems, Langen) eingesetzt. Für das Pipettieren der PCR-Reagenzien, die Zugabe des Template und den Ablauf der PCR standen getrennte Räumlichkeiten zur Verfügung. Beide PCR-Ansätze liefen unter den gleichen Reaktionsbedingungen ab.

$\underline{\text { Reaktionsansatz 1. PCR: }}$

Ready-To-Go ${ }^{\text {TM }}$ PCR Beads

Aqua dest.

DMSO

Primer Ptb1for

Primer Ptb1rev

Template (isolierte DNS)
1 Bead

$21,0 \mu \mathrm{l}$

$0,5 \mu 1$

$0,5 \mu 1$

$0,5 \mu \mathrm{l}$

$2,5 \mu \mathrm{l}$ 
$\underline{\text { Reaktionsansatz 2. PCR: }}$

Ready-To-Go ${ }^{\text {TM }}$ PCR Beads 1 Bead

Aqua dest. $\quad 21,0 \mu 1$

DMSO $0,5 \mu 1$

Primer Ptb 2for $\quad 0,5 \mu 1$

Primer Ptb 1rev $\quad 0,5 \mu 1$

Template (Produkt 1. PCR) $\quad 2,5 \mu 1$

Die PCR durchlief 30 Zyklen. Der PCR war ein Denaturierungsschritt mit der Dauer von 3 min bei $95^{\circ} \mathrm{C}$ vorgeschaltet.

Reaktionsbedingungen:

Denaturierung der DNS: $\quad 95^{\circ} \mathrm{C}, 0,5 \mathrm{~min}$

Anlagerung der Primer (Annealing): $\quad 64^{\circ} \mathrm{C}, 1,0 \mathrm{~min}$

Synthese (Elongation): $\quad 72^{\circ} \mathrm{C}, 1,0 \mathrm{~min}$

Den Abschluß der PCR bildet die Verlängerung des Syntheseschrittes $\left(72^{\circ} \mathrm{C}\right)$ auf $8 \mathrm{~min}$.

\section{$\underline{\text { Agarosegelelektrophorese }}$}

$\underline{\text { Material }}$

- Agarose:

SeaKem ${ }^{\circledR} L E$ (Biozym, Oldendorf)

- TAE-Puffer (50x): 242 g Tris (Serva, Heidelberg)

$57,1 \mathrm{ml}$ Eisessig (100\%-ige Essigsäure, Roth, Karlsruhe)

$100 \mathrm{ml}$ 0,5 M EDTA (Sigma, Taufkirchen), pH 8,0 mit NaOH

(Roth, Karlsruhe) eingestellt

- DNS-Ladepuffer (10x): 50\% Sucrose (W/V, Sigma, Taufkirchen)

$5 \%$ SDS (W/V, Serva, Heidelberg)

$0,25 \%$ Bromphenolblau (W/V)

50 mM EDTA (Sigma, Taufkirchen), pH 8,0 mit NaOH

(Roth, Karlsruhe) eingestellt

- Längenstandard: $\quad 100$ bp DNS-Leiter (Gibco-BRL, Eggenstein)

- Ethidiumbromid: $\quad$ 1\%-ige Ethidiumbromidlösung (Roth, Karlsruhe)

Mittels einer Gelelektrophorese („Wide Mini-sub Cell GT“, Biorad, München) wurden die PCR-Produkte dargestellt. Es wurden $9 \mu$ l eines jeden PCR-Ansatzes mit $1 \mu$ l DNSLadepuffer vermischt und in einem 1\%-igen Agarosegel bei 100 Volt und 45 min Laufzeit aufgetrennt. Das Färben der Gele erfolgte in einem separaten Ethidiumbromid-Bad $(1 \mu \mathrm{g} / \mathrm{ml})$ über eine Dauer von 10 min. Die DNS-Banden wurden mittels UV-Licht (Wellenlänge 302 $\mathrm{nm})$ sichtbar gemacht. Die Dokumentation erfolgte mit dem Geldokumentationssystem EAGLE EYE II (Stratagene, Amsterdam, Niederlande). 
Die Untersuchungen haben gezeigt, dass im Svanovir-ELISA mehr Reagenten zu finden waren als im IDEXX-ELISA. Deshalb wurden, unter zu Hilfenahme des Programms Excel, die Korrelationen beider Tests zueinander bestimmt. Dies erfolgte mit der Funktion „KORREL“ sowohl für die absoluten OD-Werte als auch für die relativen Messwerte in Prozent.

Sämtliche ELISA-Ergebnisse, die zur Verfügung standen, wurden sowohl für den Svanovirals auch für den IDEXX-ELISA in eine Excel-Tabelle eingegeben und berechnet.

\subsubsection{Verwendung des GLMM (generalized linear mixed model) zur statistischen Analyse der Korrelation von SVANOVIR_optischer Dichte und IDEXX_optischer Dichte}

Der Zusammenhang zwischen den Werten der optischen Dichte des Svanovir-ELISAs (SV_dens) und den Werten der optischen Dichte des IDEXX-ELISAs (ID_dens) wurde gemäß der „Mixed model“-Theorie analysiert. Die Assoziationsstudie wurde durchgeführt, indem SV_dens als abhängige Variable und ID_dens als beschreibende Variable definiert wurde. Die Anwendung von linear gemischten Modellen unter Einbeziehung fixer und zufälliger Effekte setzt eine Gaussche Verteilung der zu überprüfenden Variablen voraus. Für das Datenmaterial von SV_dens wurde jedoch eine Verteilung nach Poisson vorausgesetzt (Abb. $51)$.

Als Erweiterungsmöglichkeit für lineare gemischte Modelle erlauben aktuelle Neuentwicklungen in statistischen Methoden die Anwendung der so genannten "generalisierten mixed model“"-Technik (GLMM), (171). Diese ermöglicht auch die Analyse normalverteilter, binomial- oder Poisson-verteilter Datensätze. Charakteristikum des GLMM ist eine LinkFunktion, welche die definierte Datenstruktur mit einem linearen Schätzwert verbindet. Sie ist daher auf ein erweitertes Spektrum von Problemen der Datenanalyse zugeschnitten, v.a. wenn die Daten keiner Normalverteilung folgen oder Varianzen nicht unabhängig vom Mittelwert sind. Die lineare Komponente des linearen Modells $\eta_{i}=x_{i}^{\prime} \beta$ (xi = Spalten-Vektor von Kovariablen oder fixen Effekten, die auf den Beobachtungswert i einwirken, $\beta=$ Vektor der zu schätzenden Effekte). 
Eine verbindende Link-Funktion $g$ beschreibt die Beziehung zwischen dem Beobachtungswert yi und dem linearen Schätzwert $\eta \mathrm{i}$ :

$g\left(\mu_{i}\right)=x_{i}^{\prime} \beta$

Die Link-Funktion ist mit einer Varianzfunktion verknüpft. Im Falle einer Poisson-Verteilung ist die verbindende Funktion $\log \eta=\log (\mu)$ und die Varianzfunktion ist $V(\mu)=\mu$. Eine Umkehrfunktion wurde verwendet, um Mittelwerte auf phänotypischer Skala mittels $\eta \mathrm{i}=\mathrm{X} \beta$ zu erhalten.

Die Varianzanalyse für wiederholte Messungen (= mehrere Beobachtungen innerhalb Kuh) wurde mit dem SAS Glimmix Makro (230) durchgeführt. Das statistische Modell beinhaltete den Effekt des allgemeinen Mittelwerts, das Alter der Kühe als zeitabhängige Kovariable und eine Regression von ID_dens bis zum dritten polynomischen Grad, um die Regressionskurven bestmöglich zu beschreiben. Nicht-signifikante Regressionskoeffizienten unterschiedlicher polynomialer Struktur wurden aus dem Modell entfernt. Hierzu wurde ein F-Test bei einer Irrtumswahrscheinlichkeit von $P<0.05$ verwendet. Die F-Statistik ist identisch zur Wald/rank(K) F-Statistik, wie sie von Littell et al. (113) vorgestellt wurde. Daher entsprach das statistische Modell dem folgenden:

$$
\begin{array}{ll}
\log \left[\pi_{r}\right]= & \eta_{\mathrm{r}}=\varphi+\gamma_{\mathrm{r}}+\alpha_{1} \mathrm{AGE}_{\mathrm{r}}+\gamma_{1} \mathrm{ID}_{\mathrm{r}}+\gamma_{2} \mathrm{ID}_{\mathrm{r}}^{2}+\gamma_{3} \mathrm{ID}_{\mathrm{r}}^{3} \\
\pi_{\mathrm{r}} & =\text { Wert für SV_dens der Kuh } \mathrm{r} \\
\varphi & =\text { allgemeiner Mittelwert } \\
\gamma_{\mathrm{r}} & =\text { zufälliger Effekt der Kuh } \mathrm{r} \\
\mathrm{AGE}_{\mathrm{r}} & =\text { Alter der Kuh als zeitabhängige Ko-Variable } \\
\alpha_{1} & =\text { lineare Regression von SV_dens in Bezug auf das Alter der Kuh r } \\
\mathrm{ID}_{\mathrm{r}} & =\text { Wert für ID_dens der Kuh r } \\
\gamma_{1}, \gamma_{2}, \gamma_{3} & =\text { lineare, quadratische and kubische Regression von SV_dens zu ID_dens }
\end{array}
$$

Die "Mixed model"-Methode ermöglicht es dem Benutzer auch, bei der Analyse wiederholter Messungen die Kovarianz-Struktur der Beobachtungswerte zu definieren. Für die 1210 Kühe lagen im Durchschnitt 3.18 Beobachtungen vor, das Maximum lag bei 12 Beobachtungen pro Kuh. Bei der Modellierung wiederholter Messwerte (longitudinale Daten) sollte nicht von einer konstanten Restvarianz über den gesamten Zeitraum ausgegangen werden. Als Konsequenz daraus muss auch die Restvarianz an eine Zeitfunktion angepasst werden. Zwei Kovarianz-Strukturen wurden untersucht: die "compound symmetry" (CS) und die autoregressive 
Struktur 1. Ordnung AR(1). CS gibt an, dass die Beobachtungen desselben Tieres eine einheitliche Kovarianz und Varianz aufweisen, deshalb sind die Korrelationen zwischen allen Messwertpaaren identisch. Ein wesentlicher Nachteil dieser Methode ist, dass die CS Struktur oft unrealistisch ist, wenn die Messungen aus seriellen Messreihen bestehen, das heißt, wenn dieselbe Art von Antwort über einen längeren Zeitraum bestimmt wird. Üblicherweise korrelieren dicht aufeinander folgende Messungen besser als Messungen, die zeitmäßig weiter auseinander liegen.

Die AR(1) Struktur berücksichtigt einige der bei serieller Datenerhebung entstehenden Probleme, wenn die Messungen gleichmäßig über den Zeitraum verteilt sind, u.a geringere Korrelationen für weiter auseinander liegende Messungen. Das bedeutet, dass die AR(1) Kovarianz-Struktur einen Parameter mehr berücksichtigt als die CS Struktur (217). Die Zeitverzögerung zwischen aufeinander folgenden Messungen wurde über die zeitabhängige Kovariable „Alter der Kuh“ modelliert.

Die Wahl der geeigneteren Kovarianz-Struktur basierte auf dem Informationskriterium von Akaike (2). Akaike schlug ein einfaches und hilfreiches Kriterium (AIC) vor, um das passende Modell aus alternativen Modellvorschlägen herauszufinden:

$\mathrm{AIC}=-2(\log$ likelihood $)+2$ (Anzahl der Varianzparameter $)$

Entscheidend sind nur die Unterschiede zwischen den AIC-Werten, nicht die absoluten Werte. Das Modell mit dem niedrigsten AIC wird als das beste betrachtet. Ein weiteres, oft angewendetes Informationskriterium ist das von Bayes\&Schwarz (BIC), welches zusätzlich eine modellbedingte Unsicherheit in Betracht zieht. Das BIC ist strenger als das AIC und wird definiert als:

$\mathrm{BIC}=-2(\log$ likelihood $)-\log (\mathrm{n}) \mathrm{x}$ Anzahl der Varianzparameter

Hierbei entspricht $\mathrm{n}$ der Anzahl an Beobachtungen, die in der Analyse verwendet wurden. Die dritte Möglichkeit zur Überprüfung der beiden Modelle auf Eignung war die Anwendung des "Likelihood ratio"-Tests. 


\subsection{Verlauf der Paratuberkulose-Sanierung im Betrieb „,H“}

Im Rahmen der Paratuberkulosediagnostik wurden verschiedene diagnostische Verfahren angewendet, unter anderem der Svanovir-ELISA und der IDEXX-ELISA.

Im Zeitraum 2000 bis 2008 wurden in einem ausgewählten Betrieb insgesamt 1232 Tiere in der Paratuberkulosediagnostik untersucht. Davon waren 165 Tiere sowohl im Svanovir- als auch im IDEXX-ELISA Reagenten. Weitere 522 Tiere waren nur im Svanovir-ELISA Reagenten. Die restlichen 543 Tiere waren antikörperfrei bzw. 2 Tiere hatten einen unbekannten Status. Reagenten sind Tiere, die im jeweiligen Test positive oder zweifelhafte Ergebnisse aufweisen.

Tabelle 1: Untersuchungsergebnisse des Betriebs „ „H“ vom 08.02.2000 bis zum 09.05.2008 im Svanovir-ELISA

\begin{tabular}{|c|c|c|c|c|}
\hline Zeitpunkt & $\begin{array}{l}\text { Svanovir- } \\
\text { Reagent }\end{array}$ & Antikörperfrei & $\begin{array}{l}\text { Unbekannter } \\
\text { Status }\end{array}$ & Anzahl der Tiere \\
\hline 08.02 .2000 & 52 & 36 & 1 & 89 \\
\hline 18.12 .2001 & 71 & 21 & & 92 \\
\hline 06.05 .2002 & 62 & 40 & & 102 \\
\hline 23.01 .2003 & 59 & 41 & & 100 \\
\hline 15.06 .2004 & 59 & 28 & & 87 \\
\hline 02.02 .2005 & 50 & 47 & & 97 \\
\hline 27.07 .2005 & 68 & 28 & & 96 \\
\hline 12.12 .2005 & 44 & 51 & 1 & 96 \\
\hline 06.04 .2004 & 49 & 44 & & 93 \\
\hline 19.10 .2006 & 46 & 48 & & 94 \\
\hline 17.04 .2007 & 35 & 61 & & 96 \\
\hline 22.10 .2007 & 40 & 51 & & 91 \\
\hline 09.05 .2008 & 52 & 47 & & 99 \\
\hline Gesamt & 687 & 543 & 2 & 1232 \\
\hline
\end{tabular}




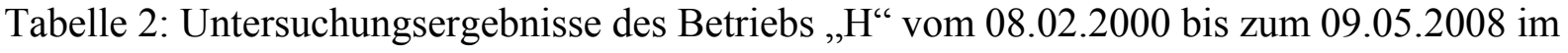
IDEXX-ELISA

\begin{tabular}{|c|c|c|c|c|}
\hline Zeitpunkt & IDEXX-Reagent & Antikörperfrei & $\begin{array}{l}\text { Unbekannter } \\
\text { Status }\end{array}$ & Anzahl der Tiere \\
\hline 08.02 .2000 & 21 & 67 & 1 & 89 \\
\hline 18.12 .2001 & 21 & 71 & & 92 \\
\hline 06.05 .2002 & 13 & 89 & & 102 \\
\hline 23.01 .2003 & 19 & 81 & & 100 \\
\hline 15.06 .2004 & 9 & 78 & & 87 \\
\hline 02.02 .2005 & 2 & 95 & & 97 \\
\hline 27.07 .2005 & 32 & 64 & & 96 \\
\hline 12.12 .2005 & 18 & 77 & 1 & 96 \\
\hline 06.04 .2006 & 10 & 83 & & 93 \\
\hline 19.10 .2006 & 7 & 87 & & 94 \\
\hline 17.04 .2007 & 4 & 92 & & 96 \\
\hline 22.10 .2007 & 4 & 87 & & 91 \\
\hline 09.05 .2008 & 5 & 94 & & 99 \\
\hline Gesamt & 165 & 1065 & 2 & 1232 \\
\hline
\end{tabular}

\subsubsection{Sanierungsfortschritt}

Der 08.02.2000 gilt als Ausgangspunkt für die Paratuberkulose-Untersuchungen im Bestand „H“. Am 08.02.2000 wurden noch keine Zugänge berücksichtigt. In den nachfolgenden Untersuchungen wurden sowohl die Zugänge als auch die Abgänge berücksichtigt. Die Zugänge und Abgänge hatten keinen einheitlichen Status, d.h., sie könnten sowohl antikörperfrei als auch Svanovir- bzw. IDEXX-Reagenten gewesen sein.

Um den Infektionsstatus innerhalb der Herde beschreiben zu können, wurde ein besonderes Diagramm entwickelt. Anhand dieses Diagramms wurde versucht, alle relevanten Veränderungen innerhalb der Herde im Laufe der Zeit zu erfassen. Das Diagramm wurde in verschiedene Felder unterteilt, welche jeweils einen möglichen Infektionsstatus der Tiere beschreiben. Z.B. erfasst das Feld „Svanovir- und IDEXX-reaktiv“ die Tiere, die in beiden ELISA-Tests entweder positiv oder grenzbereichswertig reagiert haben. Das Feld „Svanovir-reaktiv“ erfasst 
die Tiere, die nur im Svanovir-ELISA positiv oder grenzbereichswertig reagiert haben. Das Feld ,antikörperfrei“ erfasst die Tiere, bei denen keinerlei Antikörper nachgewiesen werden konnten. Das Feld „Unbekannter Status“ enthält Tiere, deren Status während der aktuellen Untersuchung noch nicht bekannt war. Im Diagramm wurden auch solche Tiere berücksichtigt, die im Vergleich zu vorherigen Untersuchung ihren Status geändert hatten: sie sind beispielsweise von „antikörperfrei“ zu „Svanovir- und IDEXX-Reagenten“ geworden, oder vom „IDEXX-Reagenten“ zum „Svanovir-Reagenten“ gewechselt.

Einige Tiere sind von IDEXX-Reagenten zur antikörperfreien Gruppe gewechselt und einige Tiere sind auch zur Gruppe mit unbekanntem Status gewechselt, oder umgekehrt.

\subsubsection{Sanierungsfortschritt zum Untersuchungszeitpunkt 08.02.2000}

Am 08.02.2000 wurden insgesamt 89 Tiere untersucht. Davon waren 52 Tiere im SvanovirELISA Reagenten (58,4\%), 36 Tiere waren antikörperfrei (40,5\%), und ein Tier gehörte zu der Gruppe mit unbekanntem Status. Von den 52 Svanovir-ELISA Reagenten waren 34 Tiere positiv und 18 Tiere lagen im Grenzbereich. 21 Tiere waren sowohl im Svanovir- als auch im IDEXX-ELISA reaktiv (23,6\%), davon waren alle 21 Tiere positiv. Am 08.02.2000 wurden keine Tiere neu eingestellt. Von der Herde wurden insgesamt 55 Tiere abgeschafft $(61,8 \%)$, davon waren 14 Tiere antikörperfrei. 19 abgeschaffte Tiere waren Svanovir-ELISAReagenten (12 Tiere positiv und 7 Tiere grenzbereichswertig). 21 Tiere waren sowohl im Svanovir- als auch im IDEXX-Test Reagenten, davon waren alle 21 Tiere IDEXX positiv. 1 Tier hatte unbekannten Status (Abb. 1). 


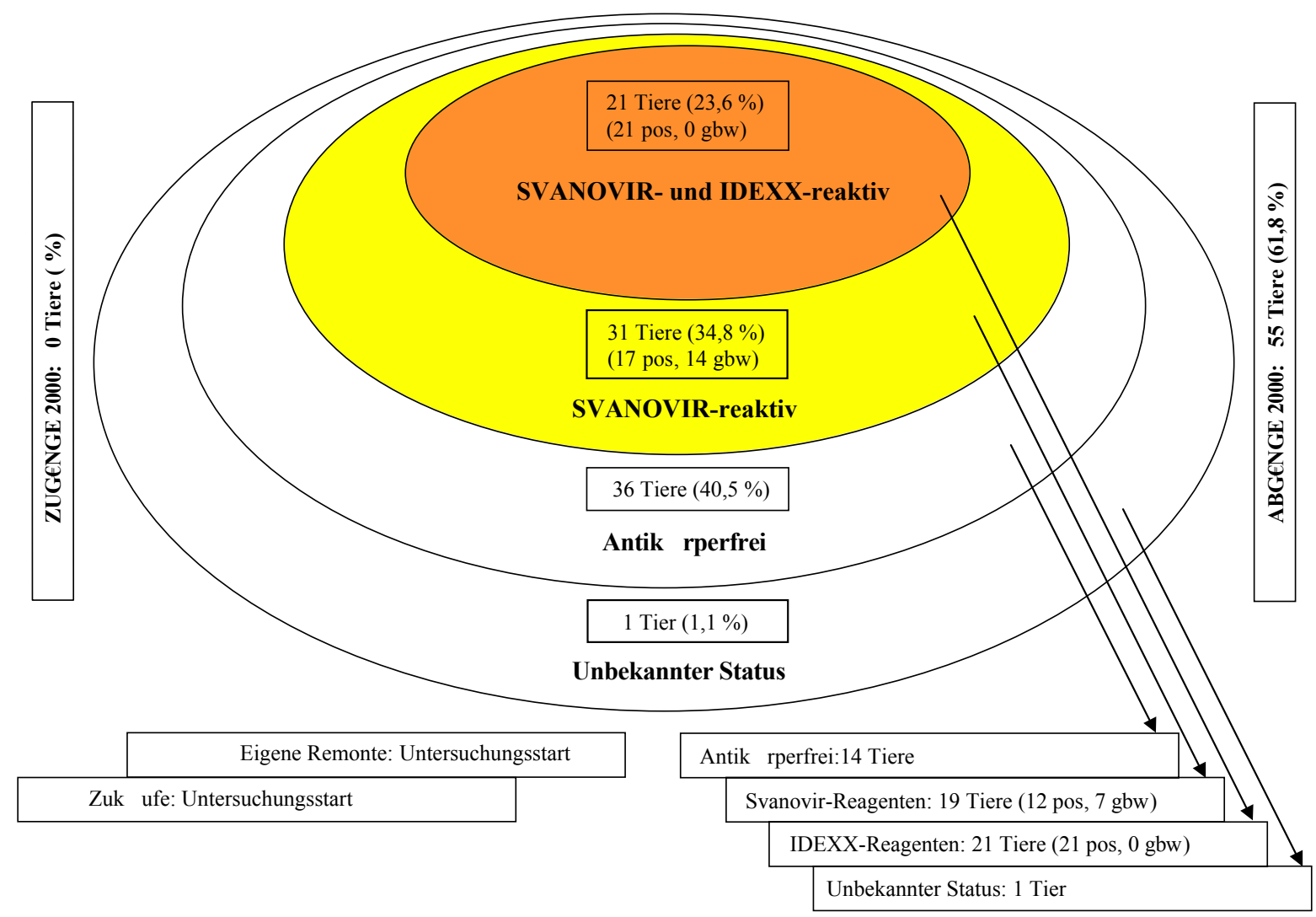

Abb. 1: Paratuberkulose-Status im Betrieb „H“ zum Zeitpunkt 08.02.2000 (Milchkühe: $\mathrm{N}=89$ )

\subsubsection{Sanierungsfortschritt zum Untersuchungszeitpunkt 18.12.2001}

Am 18.12.2001 wurden insgesamt 92 Tiere untersucht, davon waren 71 Tiere im SvanovirELISA Reagenten $(77,1 \%)$ und 21 Tiere waren antikörperfrei (22,8\%). Von den 71 SvanovirELISA Reagenten waren 48 Tiere positiv und 23 Tiere lagen im Grenzbereich. 21 Tiere waren sowohl im Svanovir- als auch im IDEXX-ELISA reaktiv (22,8\%), davon waren 6 Tiere positiv und 15 Tiere grenzbereichswertig. Im Vergleich zur vorherigen Untersuchung sind 8 Tiere von der antikörperfreien Gruppe zur im Svanovir reagierenden Gruppe gewechselt. 8 zuvor antikörperfreie Tiere sind mittlerweile zu IDEXX-Reagenten geworden. 2 Tiere aus der Svanovir-Reagenten-Gruppe sind nun in der IDEXX-Reagenten-Gruppe (Abb. 2).

Am 18.12.2001 wurden 58 Tiere (63,0\%) neu eingestellt, davon waren 11 Tiere sowohl im Svanovir- als auch im IDEXX-Test Reagenten. Davon waren 3 Tiere positiv und 8 Tiere grenzbereichswertig. 32 Tiere waren Svanovir-Reagenten, davon waren 15 Tiere Svanovirpositiv, 17 Tiere lagen im Grenzbereich für Svanovir. 15 Tiere waren antikörperfrei. Von der 


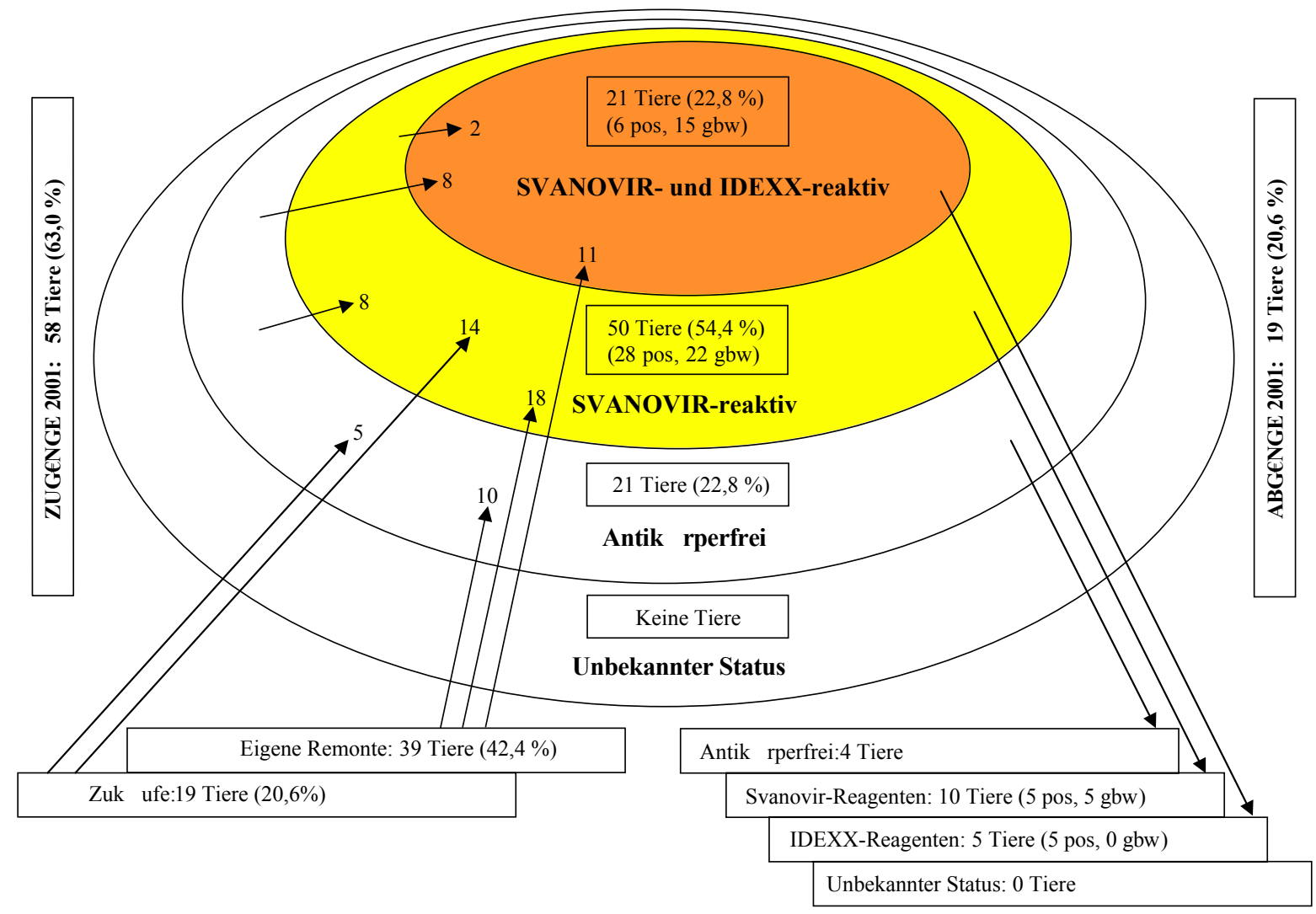

Abb. 2: Paratuberkulose-Status im Betrieb „H“ zum Zeitpunkt 18.12.2001

(Milchkühe: $\mathrm{N}=92$ )

Herde wurden insgesamt 19 Tiere abgeschafft (20,6\%), davon waren 4 Tiere antikörperfrei, 10 Tiere waren Svanovir-ELISA Reagenten (5 Tiere positiv und 5 Tiere grenzbereichswertig). 5 Tiere waren sowohl im Svanovir- als auch im IDEXX-Test Reagenten, davon waren alle 5 Tiere IDEXX positiv.

\subsubsection{Sanierungsfortschritt zum Untersuchungszeitpunkt 06.05.2002}

Am 06.05.2002 wurden insgesamt 102 Tiere untersucht, davon waren 62 Tiere im SvanovirELISA Reagenten $(60,8 \%)$ und 40 Tiere waren antikörperfrei (39,2\%). Von den 62 SvanovirELISA-Reagenten waren 51 Tiere positiv und 11 Tiere lagen im Grenzbereich. 13 Tiere waren sowohl im Svanovir- als auch im IDEXX-ELISA reaktiv (12,8\%), davon waren 6 Tiere positiv und 7 Tiere grenzbereichswertig. 


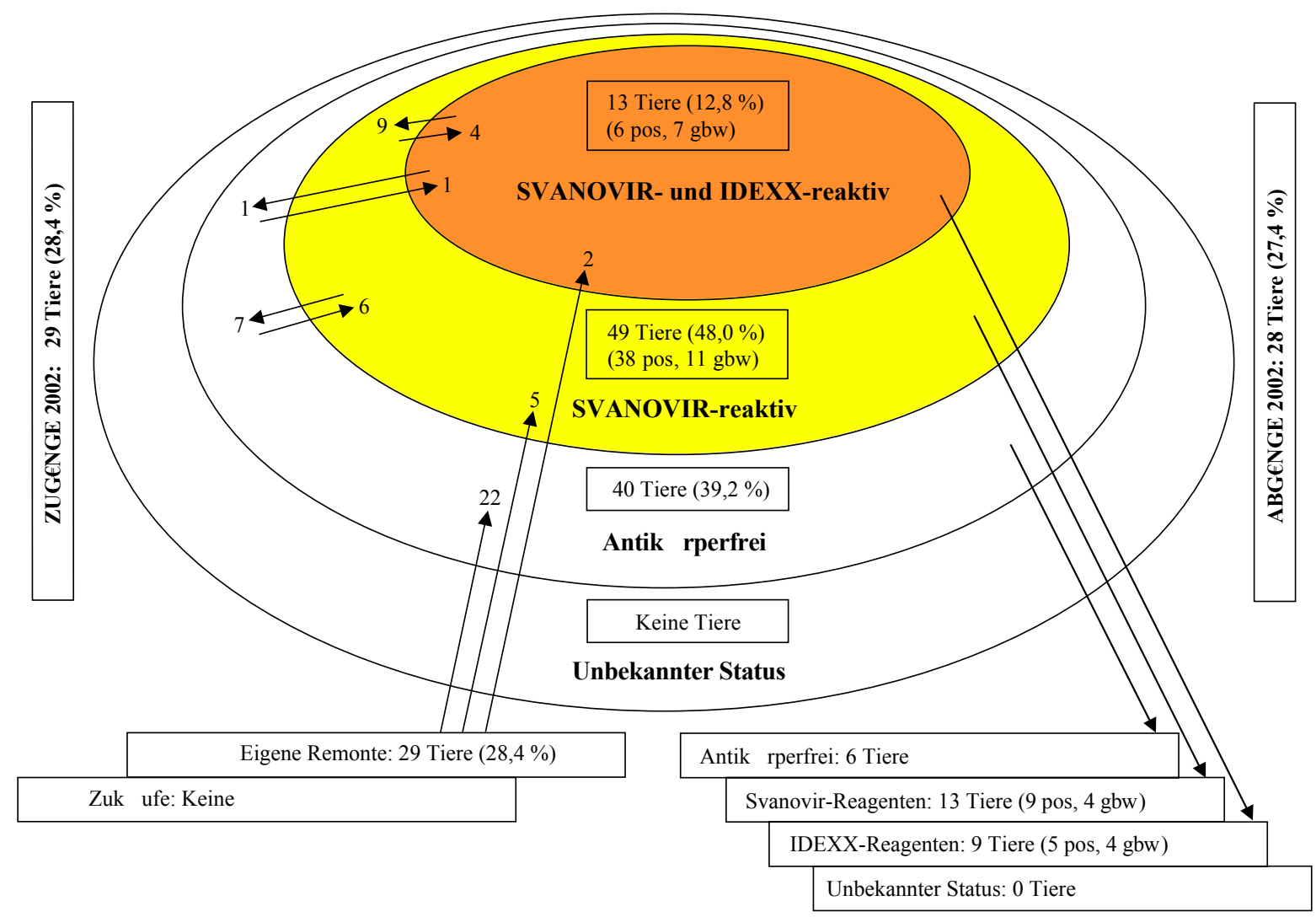

Abb. 3: Paratuberkulose-Status im Betrieb „H“ zum Zeitpunkt 06.05.2002 (Milchkühe: $\mathrm{N}=102$ )

Im Vergleich zur vorherigen Untersuchung sind 6 Tiere von der antikörperfreien Gruppe zur im Svanovir reagierenden Gruppe gewechselt. 7 Tiere sind von der im Svanovir-Test reaktiven Gruppe zu der antikörperfreien Gruppe übergewechselt. 1 zuvor antikörperfreies Tier ist mittlerweile zum IDEXX-Reagenten geworden, während 1 Tier aus der IDEXX-ReagentenGruppe nun keine nachweisbaren Antikörper mehr zeigt. 4 Tiere aus der Svanovir-ReagentenGruppe sind nun in der IDEXX-Reagenten-Gruppe und 9 Tiere von der IDEXX-ReagentenGruppe sind zu Svanovir-reaktiven Tieren geworden (Abb. 3).

Am 06.05.2002 wurden 29 Tiere (28,4\%) neu eingestellt, davon waren 2 Tiere sowohl im Svanovir- als auch im IDEXX-Test Reagenten. Davon war 1 Tier positiv und 1 Tier grenzbereichswertig. 5 Tiere waren Svanovir-Reagenten, davon waren 3 Tiere im Svanovir positiv, 2 Tiere lagen im Grenzbereich für Svanovir. 22 Tiere waren antikörperfrei. Von der Herde wurden insgesamt 28 Tiere abgeschafft $(27,4 \%)$, davon waren 6 Tiere antikörperfrei, 13 Tiere waren Svanovir-ELISA Reagenten (9 Tiere positiv und 4 Tiere grenzbereichswertig). 9 Tiere waren sowohl im Svanovir- als auch im IDEXX-Test Reagenten (5 Tiere IDEXX-positiv und 4 Tiere IDEXX-grenzbereichswertig). 


\subsubsection{Sanierungsfortschritt zum Untersuchungszeitpunkt 23.01.2003}

Am 23.01.2003 wurden insgesamt 100 Tiere untersucht, davon waren 59 Tiere im SvanovirELISA Reagenten (59,0\%) und 41 Tiere waren antikörperfrei (41,0\%). Von den 59 SvanovirELISA reaktiven Tieren waren 38 Tiere positiv und 21 Tiere grenzbereichswertig. 19 Tiere waren sowohl im Svanovir- als auch im IDEXX-ELISA Reagenten (19,0\%) (9 Tiere positiv und 10 Tiere grenzbereichswertig). Im Vergleich zur vorherigen Untersuchung sind 14 Tiere von der antikörperfreien Gruppe zur Svanovir-Reagenten-Gruppe gewechselt. Umgekehrt sind 6 Tiere von der im Svanovir reaktiven Gruppe zur antikörperfreien Gruppe gewechselt. 3 zuvor antikörperfreie Tiere sind nun zu IDEXX-reaktiven Tieren geworden.

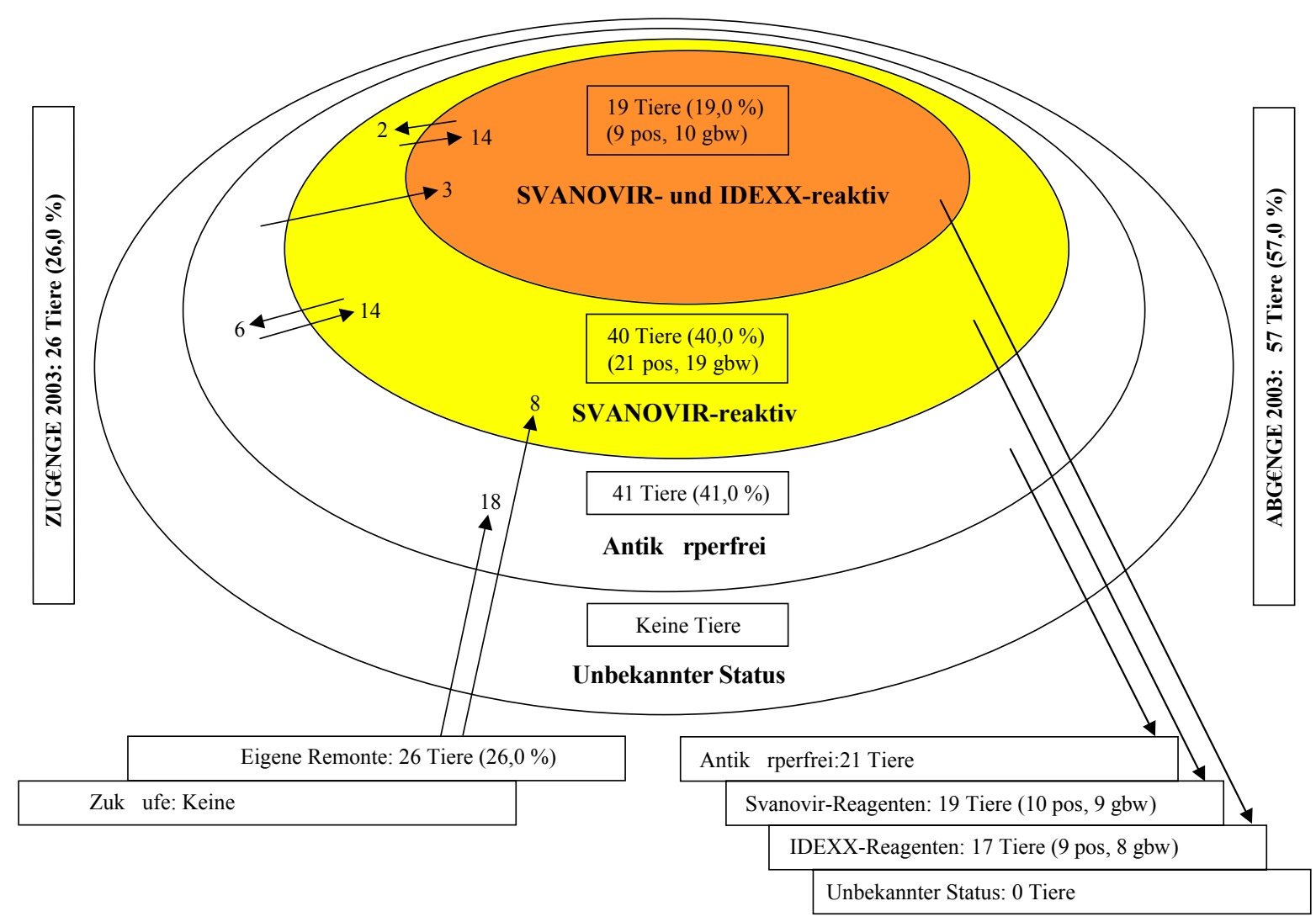

Abb. 4: Paratuberkulose-Status im Betrieb „H“ zum Zeitpunkt 23.01.2003

(Milchkühe: $\mathrm{N}=100$ )

Aus 14 Svanovir-Reagenten sind mittlerweile IDEXX-Reagenten geworden und umgekehrt sind 2 von IDEXX-Reagenten zu Svanovir-Reagenten geworden (Abb. 4).

Am 23.01.2003 wurden 26 Tiere (26,0\%) neu eingestellt, davon waren 8 Tiere SvanovirReagenten, 3 Tiere Svanovir-positiv, 5 Tiere Svanovir-grenzbereichswertig. 18 Tiere waren antikörperfrei. Von der Herde wurden insgesamt 57 Tiere abgeschafft $(57,0 \%)$, davon waren 
21 Tiere antikörperfrei und 19 Tiere waren Svanovir-ELISA-Reagenten (10 Tiere positiv und 9 Tiere grenzbereichswertig). 17 Tiere waren sowohl im Svanovir- als auch im IDEXX-Test Reagenten, davon waren 9 Tiere IDEXX-positiv und 8 Tiere IDEXX-grenzbereichswertig.

\subsubsection{5}

\section{Sanierungsfortschritt zum Untersuchungszeitpunkt 15.06.2004}

Am 15.06.2004 wurden insgesamt 87 Tiere untersucht, davon waren 59 Tiere im SvanovirELISA-Reagenten $(67,8 \%)$ und 28 Tiere waren antikörperfrei (32,2\%). Von den 59 SvanovirELISA Reagenten waren 35 Tiere positiv und 24 Tiere lagen im Grenzbereich. 9 Tiere waren

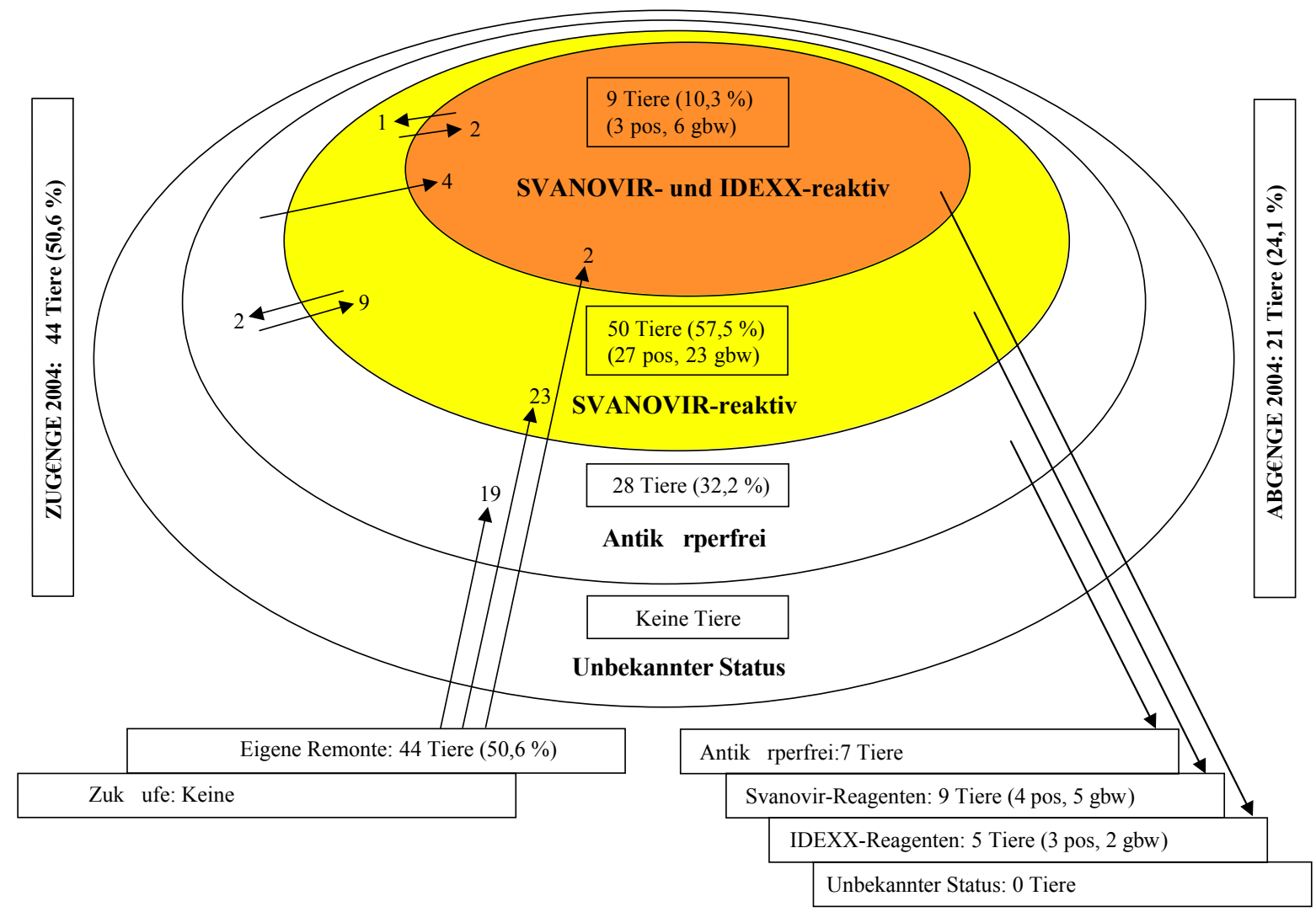

Abb. 5: Paratuberkulose-Status im Betrieb „H“ zum Zeitpunkt 15.06.2004 (Milchkühe: $\mathrm{N}=87$ )

sowohl im Svanovir- als auch im IDEXX-ELISA reaktiv (10,3\%), davon waren 3 Tiere positiv und 6 Tiere grenzbereichswertig.

Im Vergleich zur vorherigen Untersuchung sind 9 Tiere von der antikörperfreien Gruppe zur im Svanovir reagierenden Gruppe gewechselt. 2 Tiere sind von der Svanovir-reaktiven Gruppe zu der antikörperfreien Gruppe übergewechselt. 4 zuvor antikörperfreie Tiere sind mittlerweile zum IDEXX-Reagenten geworden. 2 Tiere aus der Svanovir-Reagenten-Gruppe sind 
nun in der IDEXX-Reagenten-Gruppe und 1 Tier von der IDEXX-Reagenten-Gruppe ist zum Svanovir-reaktiven Tier geworden (Abb. 5).

Am 15.06.2004 wurden 44 Tiere (50,6\%) neu eingestellt, davon waren 2 Tiere sowohl im Svanovir- als auch im IDEXX-Test Reagenten. Die beiden Tiere waren grenzbereichswertig. 23 Tiere waren Svanovir-Reagenten, davon waren 10 Tiere Svanovir-positiv, 13 Tiere lagen im Grenzbereich für Svanovir. 19 Tiere waren antikörperfrei.

\subsubsection{Sanierungsfortschritt zum Untersuchungszeitpunkt 02.02.2005}

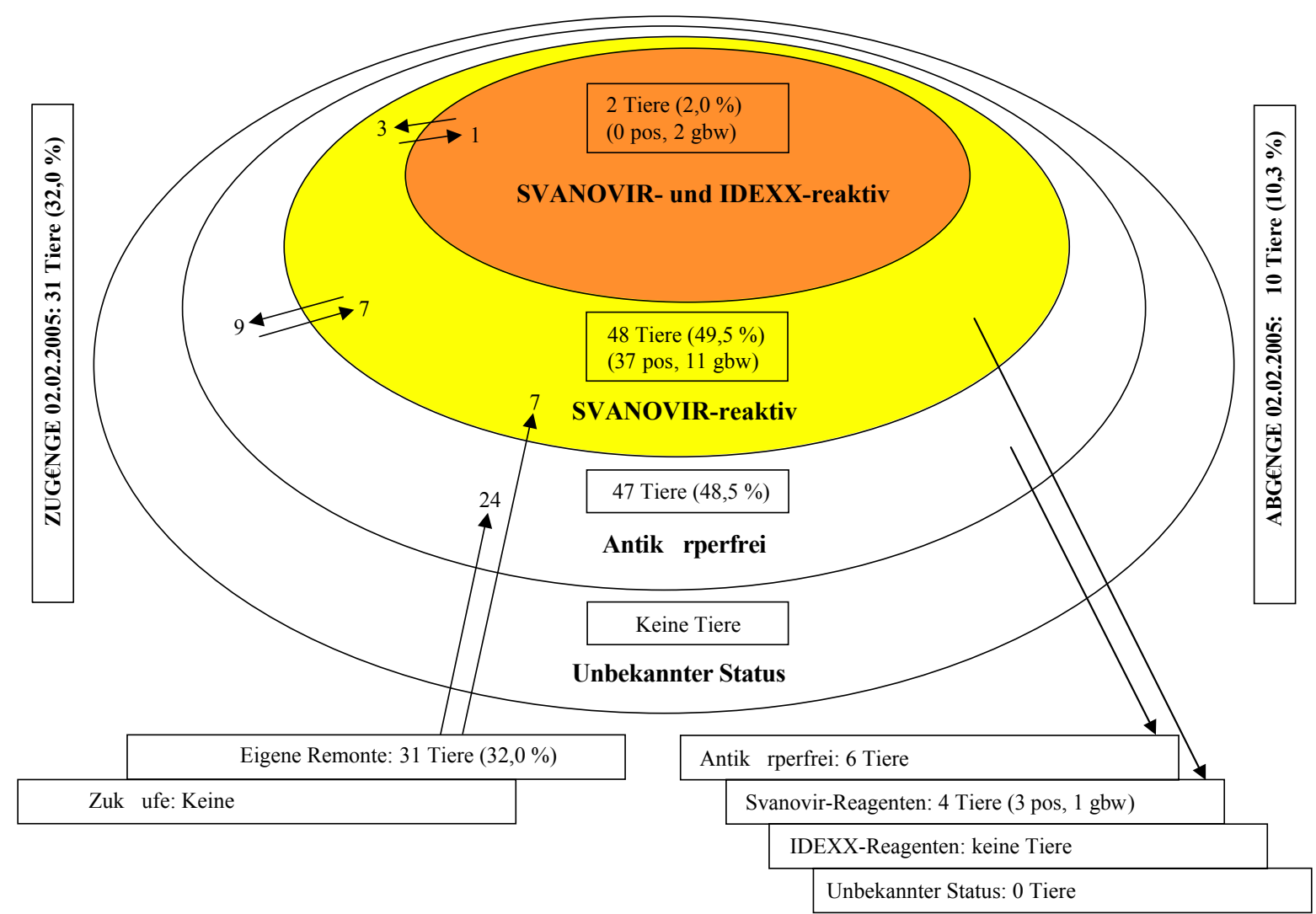

Abb. 6: Paratuberkulose-Status im Betrieb „H“ zum Zeitpunkt 02.02.2005 (Milchkühe: $\mathrm{N}=97$ )

Am 02.02.2005 wurden insgesamt 97 Tiere untersucht, davon waren 50 Tiere im SvanovirELISA-Reagenten $(51,5 \%)$ und 47 Tiere waren antikörperfrei (48,5\%). Von den 50 SvanovirELISA Reagenten waren 39 Tiere positiv und 11 Tiere lagen im Grenzbereich. 2 Tiere waren sowohl im Svanovir- als auch im IDEXX-ELISA reaktiv (2,0\%), davon waren beide Tiere grenzbereichswertig. Im Vergleich zur vorherigen Untersuchung sind 7 Tiere von der antikörperfreien Gruppe zur im Svanovir reagierenden Gruppe gewechselt. 9 Tiere sind von der Sva- 
novir-reaktiven Gruppe in die antikörperfreie Gruppe übergewechselt. 1 Tier aus der Svanovir-Reagenten-Gruppe ist nun in der IDEXX-Reagenten-Gruppe und 3 Tiere von der IDEXXReagenten-Gruppe sind zu Svanovir-reaktiven Tieren geworden (Abb. 6).

Am 02.02.2005 wurden 31 Tiere (32,0\%) neu eingestellt, 7 Tiere waren Svanovir-Reagenten, davon waren 6 Tiere Svanovir-positiv, 1 Tier lag im Grenzbereich für Svanovir. 24 Tiere waren antikörperfrei. Von der Herde wurden insgesamt 10 Tiere abgeschafft (10,3\%), davon waren 6 Tiere antikörperfrei, 4 Tiere waren Svanovir-ELISA Reagenten (3 Tiere positiv und 1 Tier grenzbereichswertig).

\subsubsection{Sanierungsfortschritt zum Untersuchungszeitpunkt 27.07.2005}

Am 27.07.2005 wurden insgesamt 96 Tiere untersucht, davon waren 68 Tiere im SvanovirELISA Reagenten (70,8\%) und 28 Tiere waren antikörperfrei (29,2\%). Von den 68 SvanovirELISA Reagenten waren 57 Tiere positiv und 11 Tiere lagen im Grenzbereich. 32 Tiere waren sowohl im Svanovir- als auch im IDEXX-ELISA reaktiv (33,3\%), davon waren 14 Tiere positiv und 18 Tiere grenzbereichswertig. Im Vergleich zur vorherigen Untersuchung sind 13 Tiere von der antikörperfreien Gruppe in die Svanovir-reagierende Gruppe gewechselt. 1 Tier ist von der Svanovir-reaktiven Gruppe zu der antikörperfreien Gruppe übergewechselt. 8 zuvor antikörperfreie Tiere sind mittlerweile zu IDEXX-Reagenten geworden. 23 Tiere aus der Svanovir-Reagenten-Gruppe sind nun in der IDEXX-Reagenten-Gruppe und 1 Tier von der IDEXX-Reagenten-Gruppe ist zum Svanovir-reaktiven Tier geworden. Ein Tier mit der Ohrmarke 12659 war in der PCR Ausscheider. Dieses Tier war im Svanovir-ELISA positiv und im IDEXX-ELISA grenzbereichswertig und wurde fristgerecht aus der Herde abgeschafft (Abb. 7).

Am 27.07.2005 wurden 9 Tiere (9,4\%) neu eingestellt, 2 Tiere waren Svanovir-Reagenten, davon war 1 Tier Svanovir-positiv, 1 Tier lag im Grenzbereich für Svanovir. 7 Tiere waren antikörperfrei. Von der Herde wurden insgesamt 15 Tiere abgeschafft $(15,6 \%)$, davon waren 3 Tiere antikörperfrei, 5 Tiere waren Svanovir-ELISA Reagenten (2 Tiere positiv und 3 Tiere grenzbereichswertig). 7 Tiere waren sowohl im Svanovir- als auch im IDEXX-Test Reagenten (4 Tiere IDEXX positiv und 3 Tiere IDEXX grenzbereichswertig). 


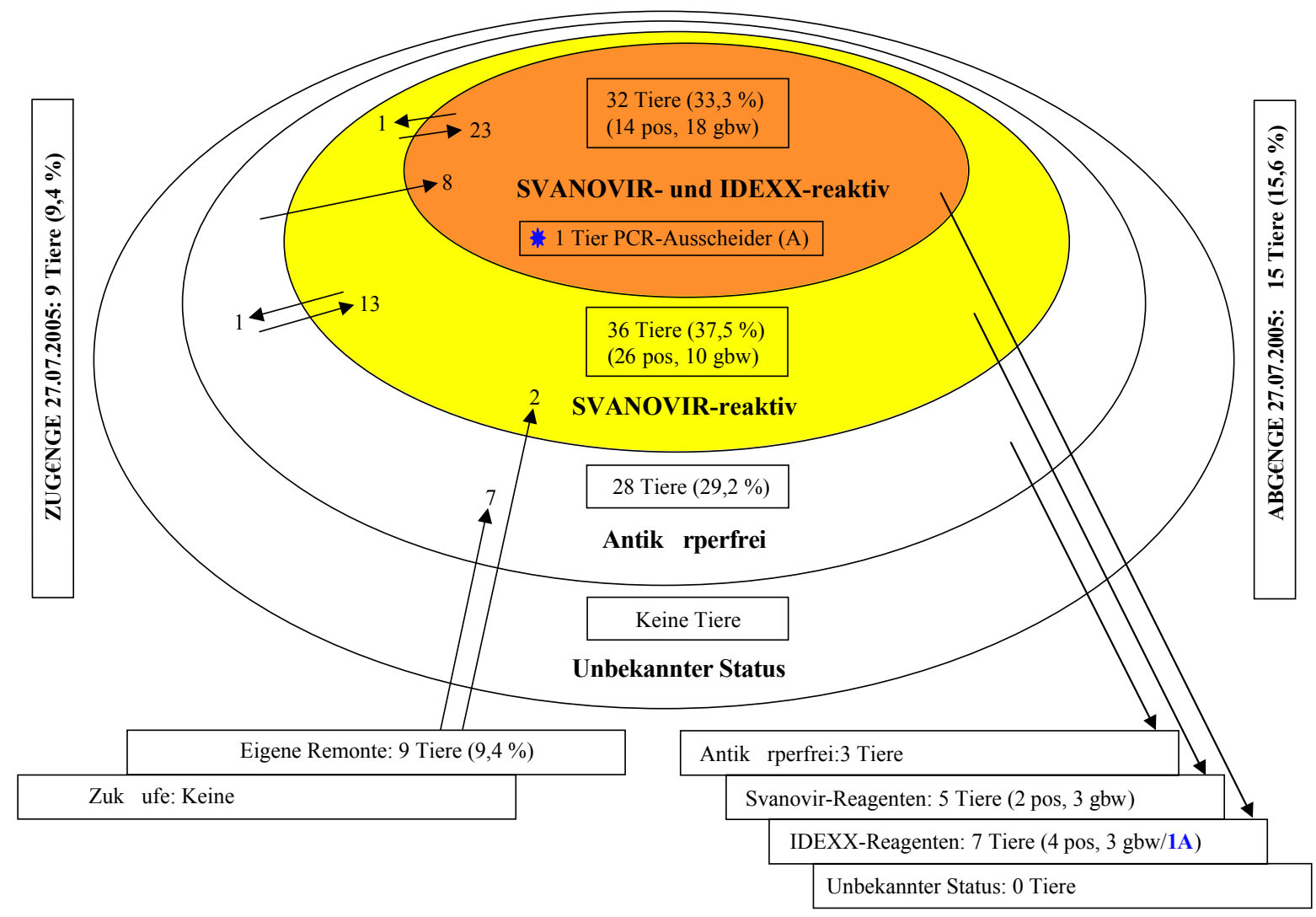

Abb. 7: Paratuberkulose-Status im Betrieb „H“ zum Zeitpunkt 27.07.2005 (Milchkühe: $\mathrm{N}=96$ )

\subsubsection{Sanierungsfortschritt zum Untersuchungszeitpunkt 12.12.2005}

Am 12.12.2005 wurden insgesamt 96 Tiere untersucht, davon waren 44 Tiere im SvanovirELISA Reagenten $(45,9 \%)$ und 51 Tiere waren antikörperfrei $(53,1 \%)$. Von den 44 SvanovirELISA Reagenten waren 28 Tiere positiv und 16 Tiere lagen im Grenzbereich. 18 Tiere waren sowohl im Svanovir- als auch im IDEXX-ELISA reaktiv (18,8\%), davon waren 5 Tiere positiv und 13 Tiere grenzbereichswertig. Im Vergleich zur vorherigen Untersuchung sind 14 Tiere von der Svanovir-reaktiven Gruppe zur antikörperfreien Gruppe übergewechselt. 2 zuvor antikörperfreie Tiere sind mittlerweile zu IDEXX-Reagenten geworden, während 2 Tiere aus der IDEXX-Reagenten-Gruppe nun keine nachweisbaren Antikörper zeigen. 2 Tiere aus der Svanovir-Reagenten-Gruppe sind nun in der IDEXX-Reagenten-Gruppe und 9 Tiere von der IDEXX-Reagenten-Gruppe sind zu Svanovir-reaktiven Tieren geworden (Abb. 8).

Am 12.12. 2005 wurden 15 Tiere (15,6\%) neu eingestellt, 2 Tiere waren Svanovir-Reagenten (1 Tier Svanovir-positiv, 1 Tier lag im Grenzbereich). 12 Tiere waren antikörperfrei und 1 Tier gehörte zu der ,unbekannter Status“-Gruppe. Von der Herde wurden insgesamt 11 Tiere 
abgeschafft (11,5\%), davon waren 7 Tiere antikörperfrei, 4 Tiere waren sowohl im Svanovirals auch im IDEXX-Test Reagenten (2 Tiere IDEXX-positiv und 2 Tiere IDEXXgrenzbereichswertig).

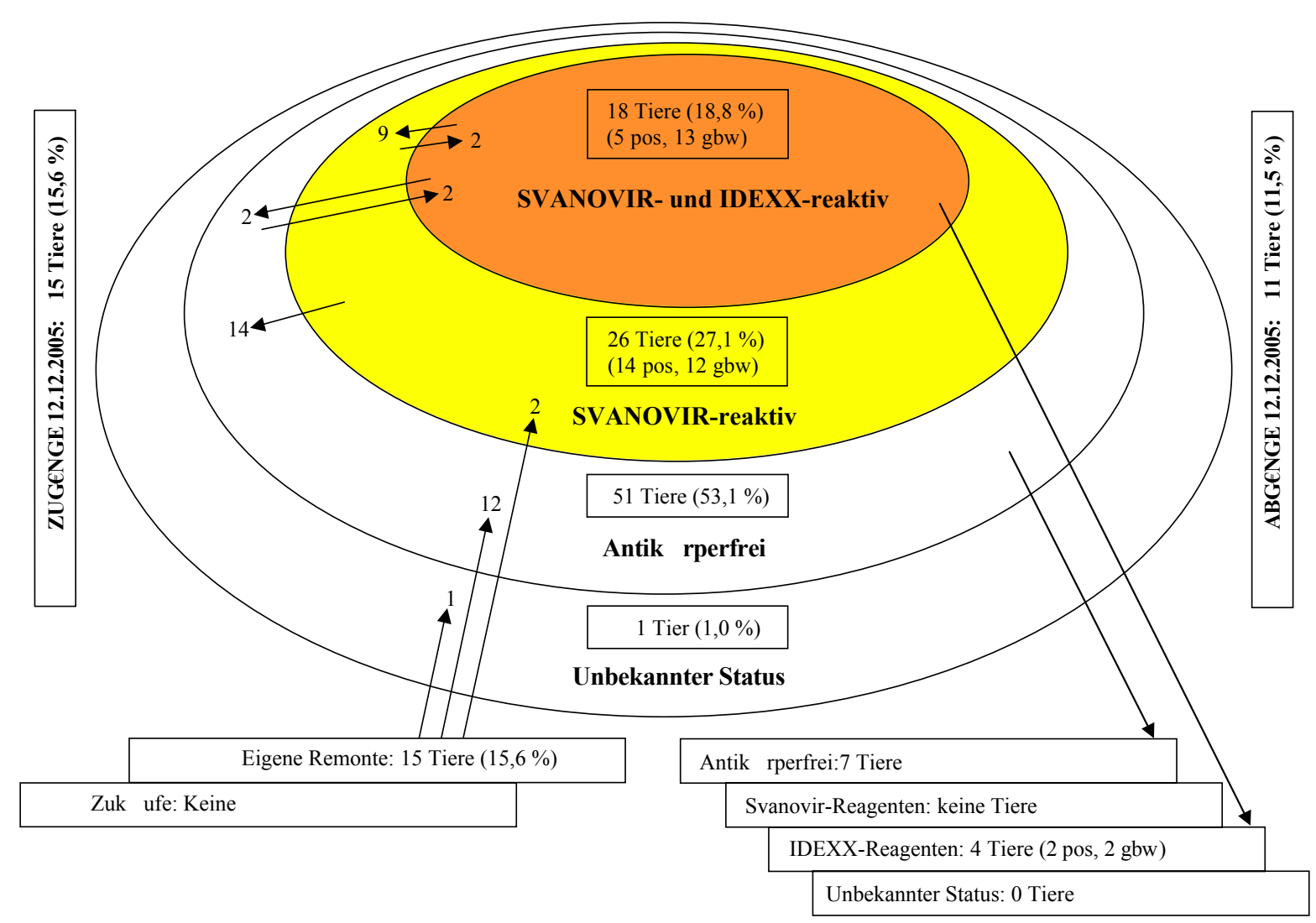

Abb. 8: Paratuberkulose-Status im Betrieb „H“ zum Zeitpunkt 12.12.2005

(Milchkühe: $\mathrm{N}=96$ )

\subsubsection{Sanierungsfortschritt zum Untersuchungszeitpunkt 06.04.2006}

Am 06.04.2006 wurden insgesamt 93 Tiere untersucht, davon waren 49 Tiere im SvanovirELISA Reagenten (52,7\%) und 44 Tiere waren antikörperfrei (47,3\%). Von den 49 SvanovirELISA-Reagenten waren 35 Tiere positiv und 14 Tiere lagen im Grenzbereich. 10 Tiere waren sowohl im Svanovir- als auch im IDEXX-ELISA reaktiv (10,8\%), davon waren 3 Tiere positiv und 7 Tiere grenzbereichswertig. Im Vergleich zur vorherigen Untersuchung sind 3 Tiere von der Svanovir-reaktiven Gruppe zu der antikörperfreien Gruppe übergewechselt und 9 antikörperfreie Tiere sind zu Svanovir-Reagenten geworden. 3 zuvor antikörperfreie Tiere sind mittlerweile zu IDEXX-Reagenten geworden, während 4 Tiere aus der IDEXXReagenten-Gruppe nun keine nachweisbaren Antikörper mehr aufweisen. 2 Tiere aus der 
Svanovir-Reagenten-Gruppe sind nun in der IDEXX-Reagenten-Gruppe und 5 Tiere von der IDEXX-Reagenten-Gruppe sind zu Svanovir-reaktiven Tieren geworden (Abb. 9).

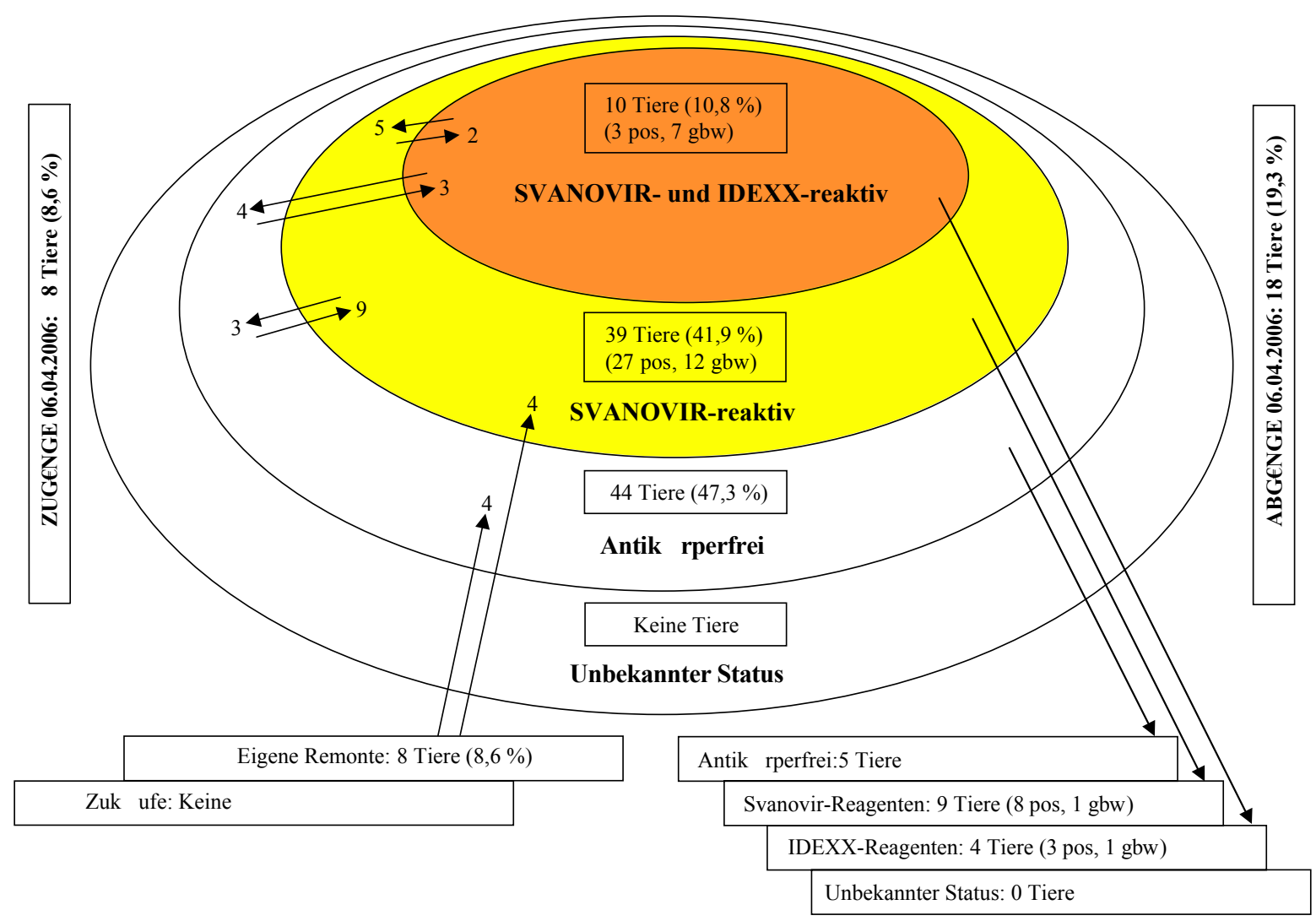

Abb. 9: Paratuberkulose-Status im Betrieb „H“ zum Zeitpunkt 06.04.2006

(Milchkühe: $\mathrm{N}=93$ )

Am 06.04.2006 wurden 8 Tiere (8,6\%) neu eingestellt, 4 Tiere waren Svanovir-Reagenten, (3 Tiere Svanovir-positiv, 1 Tiere im Grenzbereich für Svanovir), 4 Tiere waren antikörperfrei. Von der Herde wurden insgesamt 18 Tiere abgeschafft (19,4\%), davon waren 5 Tiere antikörperfrei, 9 Tiere waren Svanovir-ELISA-Reagenten (8 Tiere positiv und 1 Tier grenzbereichswertig). 4 Tiere waren sowohl im Svanovir- als auch im IDEXX-Test Reagenten, davon waren 3 Tiere IDEXX-positiv und 1 Tier IDEXX-grenzbereichswertig.

\subsubsection{Sanierungsfortschritt zum Untersuchungszeitpunkt 19.10.2006}

Am 19.10.2006 wurden insgesamt 94 Tiere untersucht, davon waren 46 Tiere im SvanovirELISA Reagenten $(48,9 \%)$ und 48 Tiere waren antikörperfrei $(51,1 \%)$. Von den 46 SvanovirELISA Reagenten waren 31 Tiere positiv und 15 Tiere lagen im Grenzbereich. 7 Tiere waren 


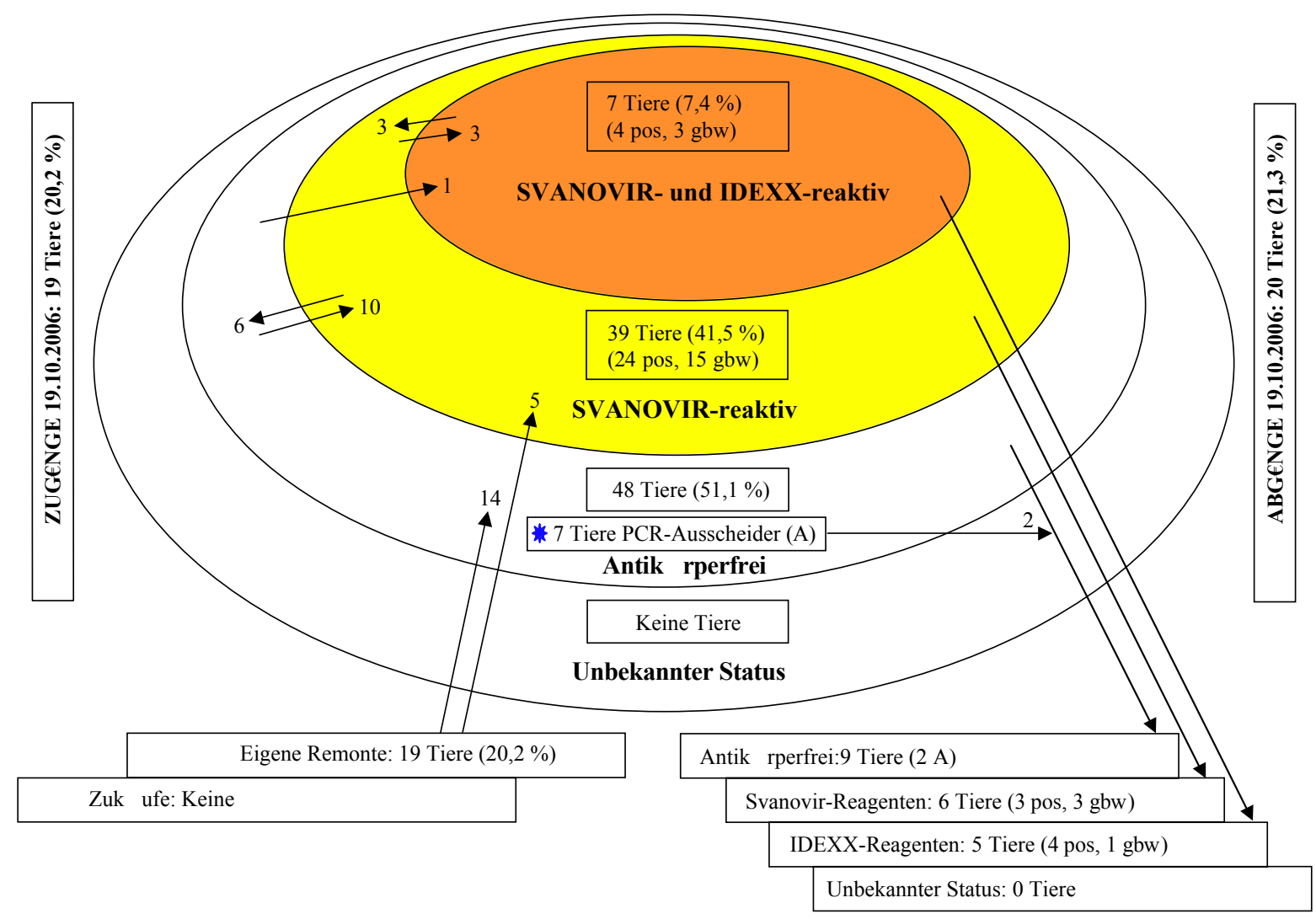

Abb. 10: Paratuberkulose-Status im Betrieb „H“ zum Zeitpunkt 19.10.2006 (Milchkühe: $\mathrm{N}=94$ )

sowohl im Svanovir- als auch im IDEXX-ELISA reaktiv (7,4\%), davon waren 4 Tiere positiv und 3 Tiere grenzbereichswertig.

Im Vergleich zur vorherigen Untersuchung sind 6 Tiere aus der Svanovir-reaktiven Gruppe zur antikörperfreien Gruppe übergewechselt, 10 Tiere sind von der antikörperfreien Gruppe zu der Svanovir-Reagenten-Gruppe gewechselt. 1 zuvor antikörperfreies Tier ist mittlerweile zum IDEXX-Reagenten geworden. 3 Tiere aus der Svanovir-Reagenten-Gruppe sind nun in der IDEXX-Reagenten-Gruppe und 3 Tiere von der IDEXX-Reagenten-Gruppe sind zu Svanovir-reaktiven Tieren geworden. Die gepoolte Kot-PCR Untersuchung zeigte, dass 7 Tiere mit den Ohrmarken 07347, 12645, 88797, 88807, 50482, 18707, 50506 MAP-Erreger mit dem Kot ausschieden, obwohl diese Tiere serologisch antikörperfrei waren (Abb. 10).

Am 19.10.2006 wurden 19 Tiere (20,2\%) neu eingestellt. 5 dieser Tiere waren SvanovirReagenten (3 Tiere Svanovir-positiv, 2 Tiere lagen im Grenzbereich). 14 Tiere waren antikörperfrei. Von der Herde wurden insgesamt 20 Tiere abgeschafft (21,3\%), davon waren 9 Tiere antikörperfrei (2 Tiere MAP-Erreger-Ausscheider in Kot-PCR), 6 Tiere waren SvanovirELISA Reagenten (3 Tiere positiv und 3 Tiere grenzbereichswertig). 5 Tiere waren sowohl im 
Svanovir- als auch im IDEXX-Test Reagenten (4 Tiere IDEXX-positiv und 1 Tier IDEXXgrenzbereichswertig).

\subsubsection{Sanierungsfortschritt zum Untersuchungszeitpunkt 17.04.2007}

Am 17.04.2007 wurden insgesamt 96 Tiere untersucht, davon waren 35 Tiere im SvanovirELISA Reagenten $(36,5 \%)$ und 61 Tiere waren antikörperfrei (63,5\%). Von den 35 SvanovirELISA-Reagenten waren 22 Tiere positiv und 13 Tiere lagen im Grenzbereich. 4 Tiere waren sowohl im Svanovir- als auch im IDEXX-ELISA reaktiv (4,2\%), davon war 1 Tier positiv

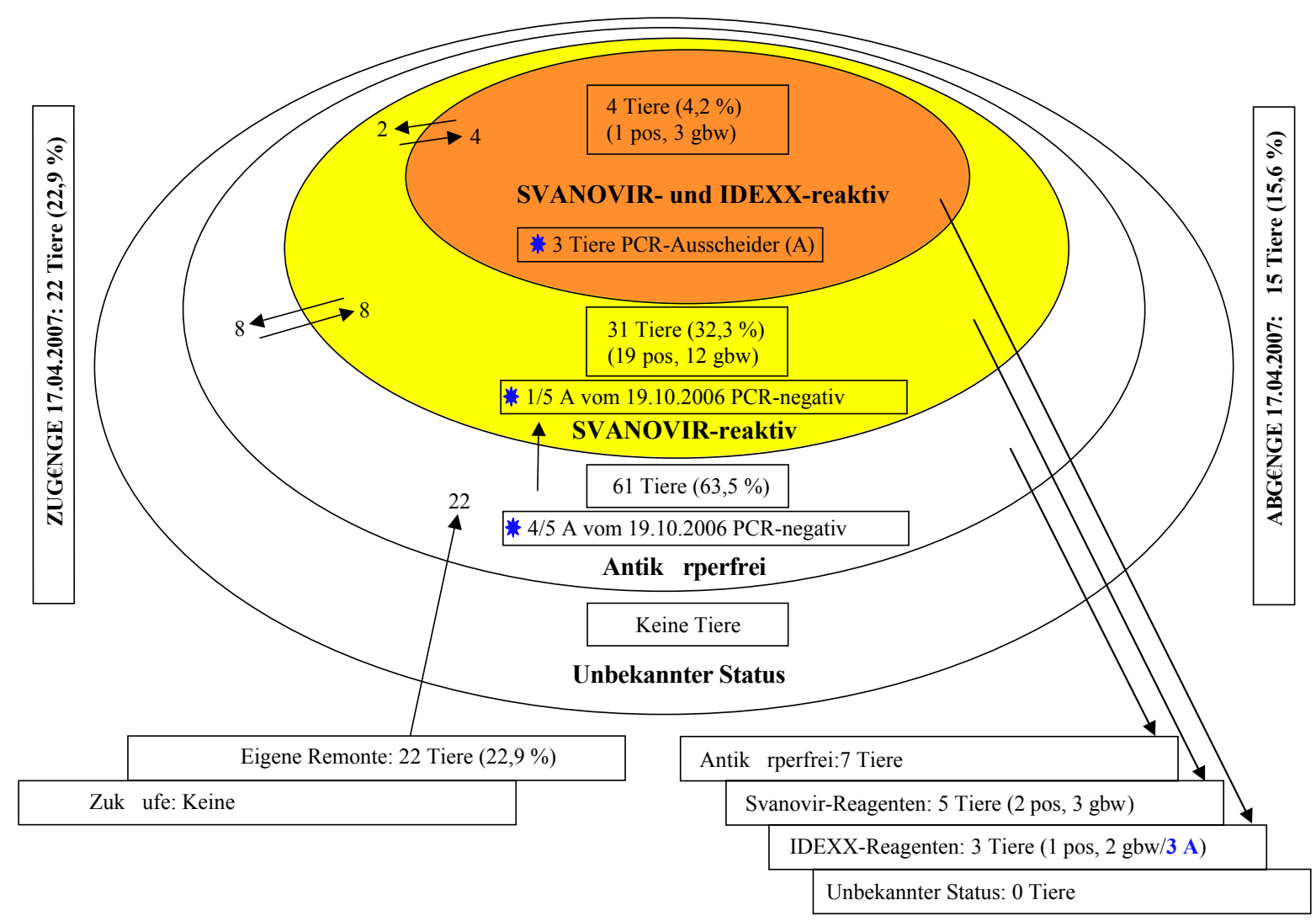

Abb. 11: Paratuberkulose-Status im Betrieb „H“ zum Zeitpunkt 17.04.2007

(Milchkühe: $\mathrm{N}=94$ )

und 3 Tiere grenzbereichswertig. Im Vergleich zur vorherigen Untersuchung sind 8 Tiere von der Svanovir-reaktiven Gruppe zu der antikörperfreien Gruppe übergewechselt und 8 Tiere sind von der antikörperfreien Gruppe zu der Svanovir-Reagenten-Gruppe gewechselt. 4 Tiere aus der Svanovir-Reagenten-Gruppe sind nun in der IDEXX-Reagenten-Gruppe und 2 Tiere von der IDEXX-Reagenten-Gruppe sind zu Svanovir-reaktiven Tieren geworden. Von den 
5 Tieren mit den Ohrmarken 12645, 50482, 50506, 88797 und 88807, welche am 19.10.2006 PCR-Kot-Ausscheider waren und immer noch in der Herde blieben, war nur das Tier mit der Ohrmarke 88797 wieder Kot-PCR-Ausscheider und bei dem Tier mit der Ohrmarke 12645 wurden Antikörper im Svanovir-ELISA detektiert. Die restlichen 4 Tiere waren erneut wieder antikörperfrei. Am 17.04.2007 wurden drei weitere Tiere (Ohrmarken 12654, 18681 und 88817) über die Kot-PCR als MAP-Erreger-Ausscheider festgestellt. Diese drei Tiere waren sowohl im Svanovir- als auch im IDEXX-ELISA Reagenten und wurden fristgerecht aus der Herde abgeschafft (Abb. 11).

Am 17.04.2007 wurden 22 Tiere (22,9\%) neu eingestellt, alle 22 Tiere waren antikörperfrei. Von der Herde wurden insgesamt 15 Tiere abgeschafft (15,6\%), davon waren 7 Tiere antikörperfrei, 5 Tiere waren Svanovir-ELISA-Reagenten (2 Tiere positiv und 3 Tiere grenzbereichswertig). 3 Tiere waren sowohl im Svanovir- als auch im IDEXX-Test Reagenten, davon war 1 Tier IDEXX-positiv und 2 Tiere IDEXX-grenzbereichswertig.

\subsubsection{Sanierungsfortschritt zum Untersuchungszeitpunkt 22.10.2007}

Am 22.10.2007 wurden insgesamt 91 Tiere untersucht, davon waren 40 Tiere im SvanovirELISA Reagenten (44,0\%) und 51 Tiere waren antikörperfrei (56,0\%). Von den 40 SvanovirELISA-Reagenten waren 28 Tiere positiv und 12 Tiere lagen im Grenzbereich. 4 Tiere (4,4\%) waren sowohl im Svanovir- als auch im IDEXX-ELISA reaktiv (1 Tier positiv und 3 Tiere grenzbereichswertig). Im Vergleich zur vorherigen Untersuchung sind 4 Tiere von der Svanovir-reaktiven Gruppe zu der antikörperfreien Gruppe übergewechselt. 15 antikörperfreie Tiere sind mittlerweile zu Svanovir-Reagenten geworden. 1 Tier von der antikörperfreien Gruppe ist mittlerweile IDEXX-Reagent. 2 Tiere aus der Svanovir-Reagenten-Gruppe sind nun in der IDEXX-Reagenten-Gruppe. Von den 4 Tieren mit den Ohrmarken 12645, 50482, 50506 und 88807, welche trotz Ausscheidung des Erregers (Kot-PCR) am 19.10.2006 in der Herde verblieben waren, waren 3 immer noch antikörperfrei und das Tier mit der Ohrmarke 12645 blieb weiterhin im Svanovir-ELISA reaktiv (Abb. 12).

Am 22.10.2007 wurden 10 Tiere $(11,0 \%)$ neu eingestellt, 1 Tier war Svanovirgrenzbereichswertig, 9 Tiere waren antikörperfrei. Von der Herde wurden insgesamt 18 Tiere abgeschafft $(19,8 \%)$, davon waren 7 Tiere antikörperfrei (1 Tier MAP-Erreger-Ausscheider in der Kot-PCR) und 10 Tiere Svanovir-ELISA-Reagenten (9 Tiere positiv und 1 Tier Svanovirgrenzbereichswertig). 1 Tier war sowohl im Svanovir- als auch im IDEXX-Test Reagent, dieses war IDEXX positiv. 


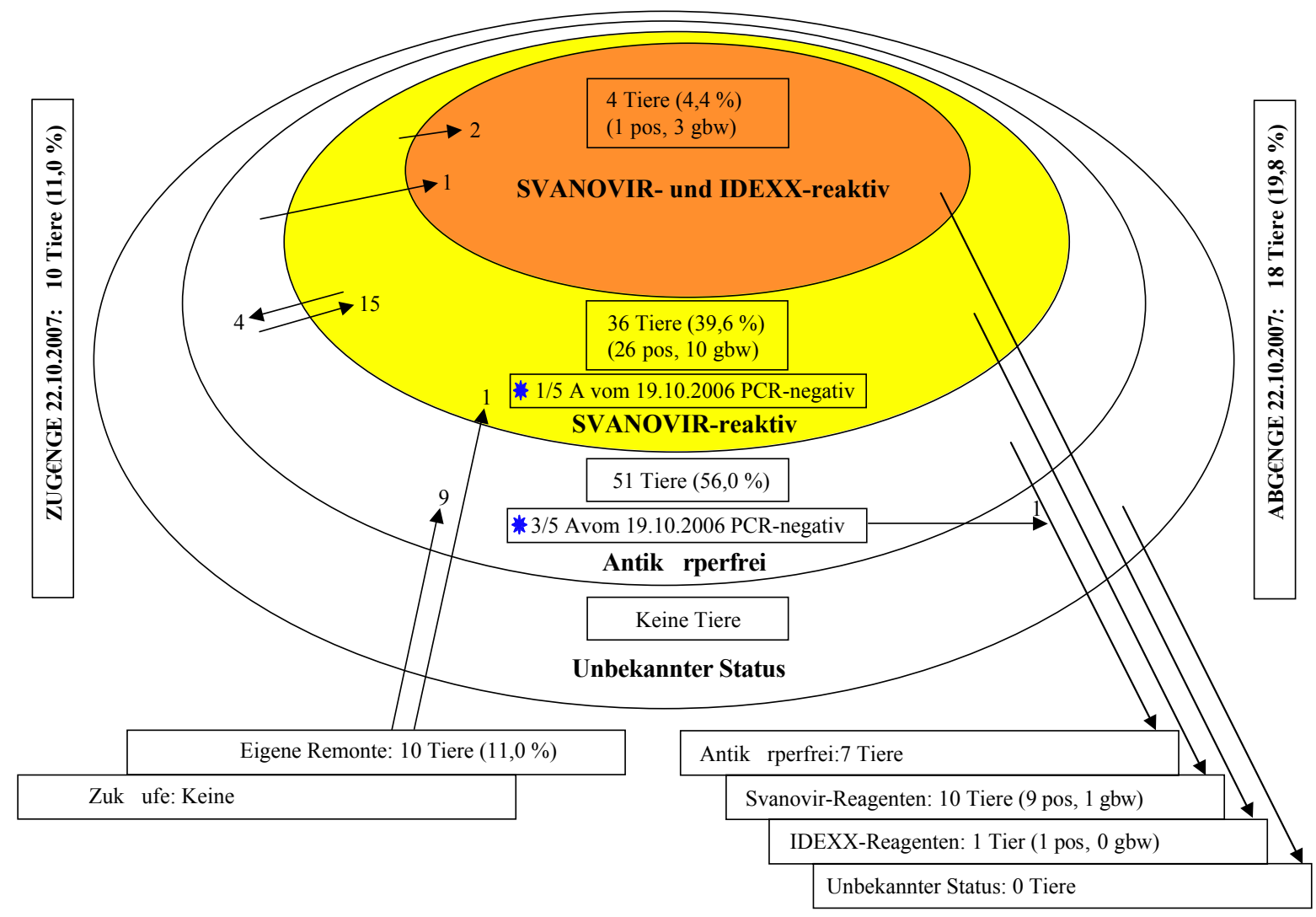

Abb. 12: Paratuberkulose-Status im Betrieb „H“ zum Zeitpunkt 22.10.2007 (Milchkühe: $\mathrm{N}=91$ )

\subsubsection{Sanierungsfortschritt zum Untersuchungszeitpunkt 09.05.2008}

Am 09.05.2008 wurden insgesamt 99 Tiere untersucht, davon waren 52 Tiere im SvanovirELISA Reagenten (52,5\%) und 47 Tiere waren antikörperfrei (47,5\%). Von den 52 SvanovirELISA-Reagenten waren 38 Tiere positiv und 14 Tiere lagen im Grenzbereich. 5 Tiere waren sowohl im Svanovir- als auch im IDEXX-ELISA reaktiv $(5,0 \%)$, davon war 1 Tier positiv und 4 Tiere grenzbereichswertig. Im Vergleich zur vorherigen Untersuchung sind 18 Tiere von der antikörperfreien Gruppe zu der Svanovir-reaktiven Gruppe übergewechselt. 2 Tiere sind von der Svanovir-Reagenten-Gruppe zu der antikörperfreien Gruppe gewechselt. 2 Tiere von der antikörperfreien Gruppe sind mittlerweile zu IDEXX-Reagenten geworden, während 1 Tier aus der IDEXX-Reagenten-Gruppe nun keine nachweisbaren Antikörper mehr zeigt. 1 Tier ist aus der Svanovir-Reagenten-Gruppe zur IDEXX-Reagenten-Gruppe gewechselt, wohingegen 1 Tier der IDEXX-Reagenten zu der Svanovir-Reagenten-Gruppe gewechselt ist. Die 4 Tiere mit den Ohrmarken 12645, 50482, 50506 und 88807, welche am 19.10.2006 in der Kot-PCR Ausscheider waren, blieben immer noch in der Herde und bei allen Tieren wur- 
den im Svanovir-ELISA Antikörper detektiert (Abb. 13). Am 09.05.2008 wurden 26 Tiere (26,3\%) neu eingestellt, davon war 1 Tier sowohl im Svanovir- als auch im IDEXX-Test reaktiv, dieses war im IDEXX grenzbereichswertig. 5 Tiere waren Svanovir-Reagenten, davon waren 4 Tiere im Svanovir positiv, 1 Tier im Svanovir grenzbereichswertig. 20 Tiere waren antikörperfrei. Von der Herde wurden insgesamt 23 Tiere abgeschafft $(23,2 \%)$, davon waren 11 Tiere antikörperfrei, 10 Tiere Svanovir-ELISA-Reagenten (6 Tiere positiv und 4 Tier Svanovir-grenzbereichswertig). 2 Tiere waren sowohl im Svanovir- als auch im IDEXX-Test Reagenten, davon war 1 Tier IDEXX-positiv und 1 Tier IDEXX-grenzbereichswertig.

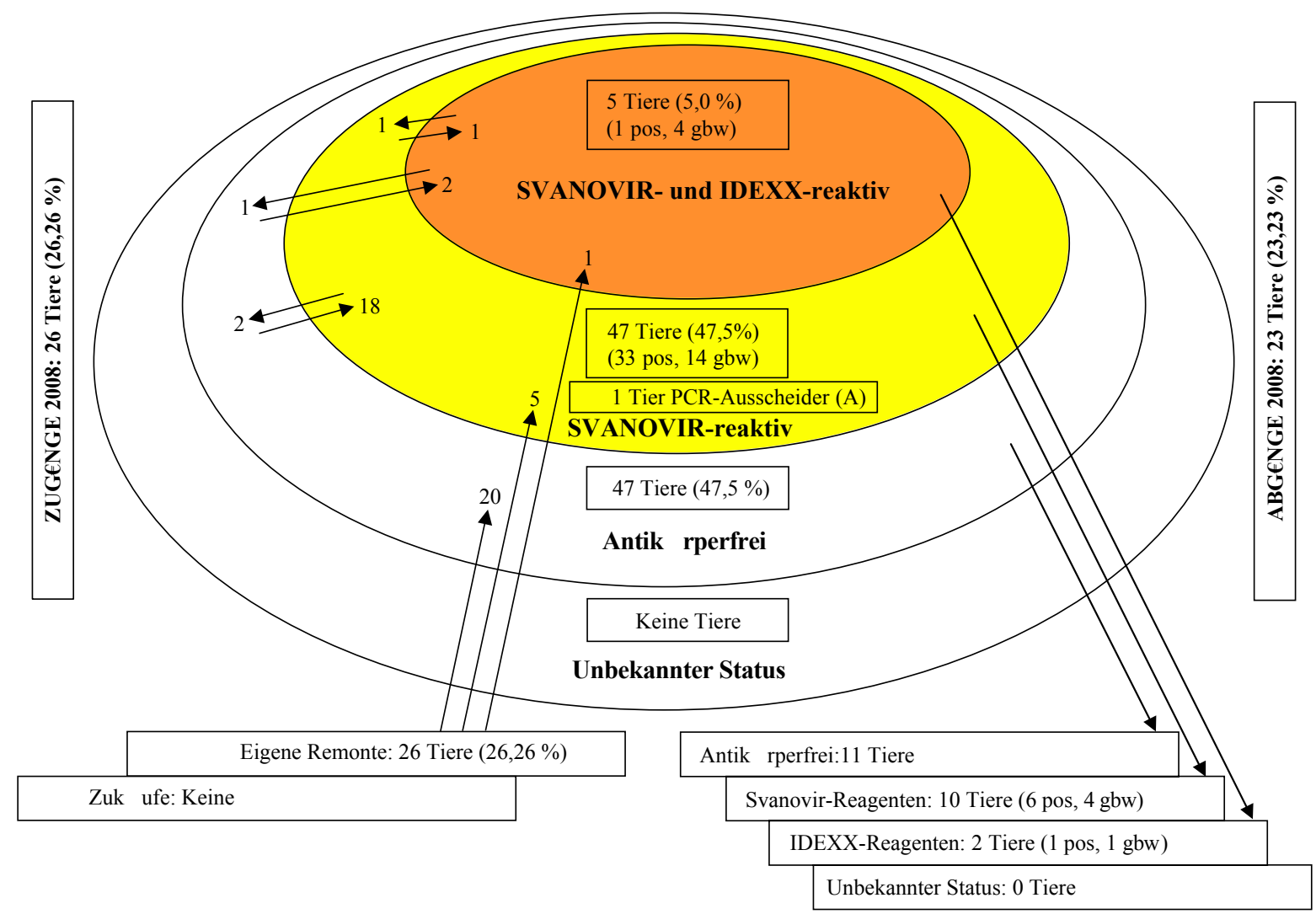

Abb. 13: Paratuberkulose-Status im Betrieb „H“ zum Zeitpunkt 09.05.2008 (Milchkühe: $\mathrm{N}=99$ )

\subsubsection{Infektionsrate}

Um die Infektiosrate in der Herde für die entsprechenden serologischen Tests zu bestimmen, wurde die Anzahl der Svanovir-Reagenten berechnet und die Anzahl der Reagenten durch die Gesamtzahl der Tiere dividiert. Dies wurde auch für IDEXX-Reagenten und für antikörperfreie Tiere durchgeführt. 


\subsubsection{Prozentualer Anteil von Svanovir- und IDEXX-Reagenten in der Herde}

Am 08.02.2000 wurden insgesamt 89 Tiere untersucht. Von der gesamten Herde waren 23,6\% der Tiere sowohl im Svanovir-Test als auch im IDEXX-ELISA Reagenten. 34,8\% der Tiere waren Svanovir-Reagenten, 40,5\% der Tiere waren antikörperfrei und ein Tier $(1,1 \%)$ gehörte zu der Gruppe unbekannter Status.

Am 18.12.2001 wurden insgesamt 92 Tiere untersucht. Von der gesamten Herde waren 22,8\% der Tiere sowohl im Svanovir-Test als auch im IDEXX-ELISA Reagenten. 54,4\% der Tiere waren Svanovir-Reagenten und 22,8\% der Tiere waren antikörperfrei.

Am 06.05.2002 wurden insgesamt 102 Tiere untersucht. Von der gesamten Herde waren 12,8\% der Tiere sowohl im Svanovir-Test als auch im IDEXX-ELISA Reagenten. 48,0\% der Tiere waren Svanovir-Reagenten und 39,2\% der Tiere waren antikörperfrei.

Am 23.01.2003 wurden insgesamt 100 Tiere untersucht. Von der gesamten Herde waren 19,0\% der Tiere sowohl im Svanovir-Test als auch im IDEXX-ELISA Reagenten. 40,0\% der Tiere waren Svanovir-Reagenten und 41,0\% der Tiere waren antikörperfrei.

Am 15.06.2004 wurden insgesamt 87 Tiere untersucht. Von der gesamten Herde waren 10,3\% der Tiere sowohl im Svanovir-Test als auch im IDEXX-ELISA Reagenten. 57,5\% der Tiere waren Svanovir-Reagenten und 32,2\% der Tiere waren antikörperfrei.

Am 02.02.2005 wurden insgesamt 97 Tiere untersucht. Von der gesamten Herde waren 2,0\% der Tiere sowohl im Svanovir-Test als auch im IDEXX-ELISA Reagenten. 49,5\% der Tiere waren Svanovir-Reagenten und 48,5\% der Tiere waren antikörperfrei (Abb. 14-16).

Am 27.07.2005 wurden insgesamt 96 Tiere untersucht. Von der gesamten Herde waren 33,3\% der Tiere sowohl im Svanovir-Test als auch im IDEXX-ELISA Reagenten. 37,5\% der Tiere waren Svanovir-Reagenten und 29,2\% der Tiere waren antikörperfrei.

Am 12.12.2005 wurden insgesamt 96 Tiere untersucht. Von der gesamten Herde waren 18,8\% der Tiere sowohl im Svanovir-Test als auch im IDEXX-ELISA Reagenten. 27,1\% der Tiere waren Svanovir-Reagenten und 53,1\% der Tiere waren antikörperfrei und ein Tier $(1,0 \%)$ gehörte zu der Gruppe antikörperfreier Status.

Am 06.04.2006 wurden insgesamt 93 Tiere untersucht. Von der gesamten Herde waren 10,8\% der Tiere sowohl im Svanovir-Test als auch im IDEXX-ELISA Reagenten. 41,9\% der Tiere waren Svanovir-Reagenten und 47,3\% der Tiere waren antikörperfrei.

Am 19.10.2006 wurden insgesamt 94 Tiere untersucht. Von der gesamten Herde waren 7,4\% der Tiere sowohl im Svanovir-Test als auch im IDEXX-ELISA Reagenten. 41,5\% der Tiere waren Svanovir-Reagenten und 51,1\% der Tiere waren antikörperfrei. 
Am 17.04.2007 wurden insgesamt 96 Tiere untersucht. Von der gesamten Herde waren 4,2\% der Tiere sowohl im Svanovir-Test als auch im IDEXX-ELISA Reagenten. 32,3\% der Tiere waren Svanovir-Reagenten und 63,5\% der Tiere waren antikörperfrei.

Am 22.10.2007 wurden insgesamt 91 Tiere untersucht. Von der gesamten Herde waren 4,4\% der Tiere sowohl im Svanovir-Test als auch im IDEXX-ELISA Reagenten. 39,6\% der Tiere waren Svanovir-Reagenten und 56,0\% der Tiere waren antikörperfrei.

Am 09.05.2008 wurden insgesamt 99 Tiere untersucht. Von der gesamten Herde waren 5,0\% der Tiere sowohl im Svanovir-Test als auch im IDEXX-ELISA Reagenten. 47,5\% der Tiere waren Svanovir-Reagenten und 47,5\% der Tiere waren antikörperfrei.

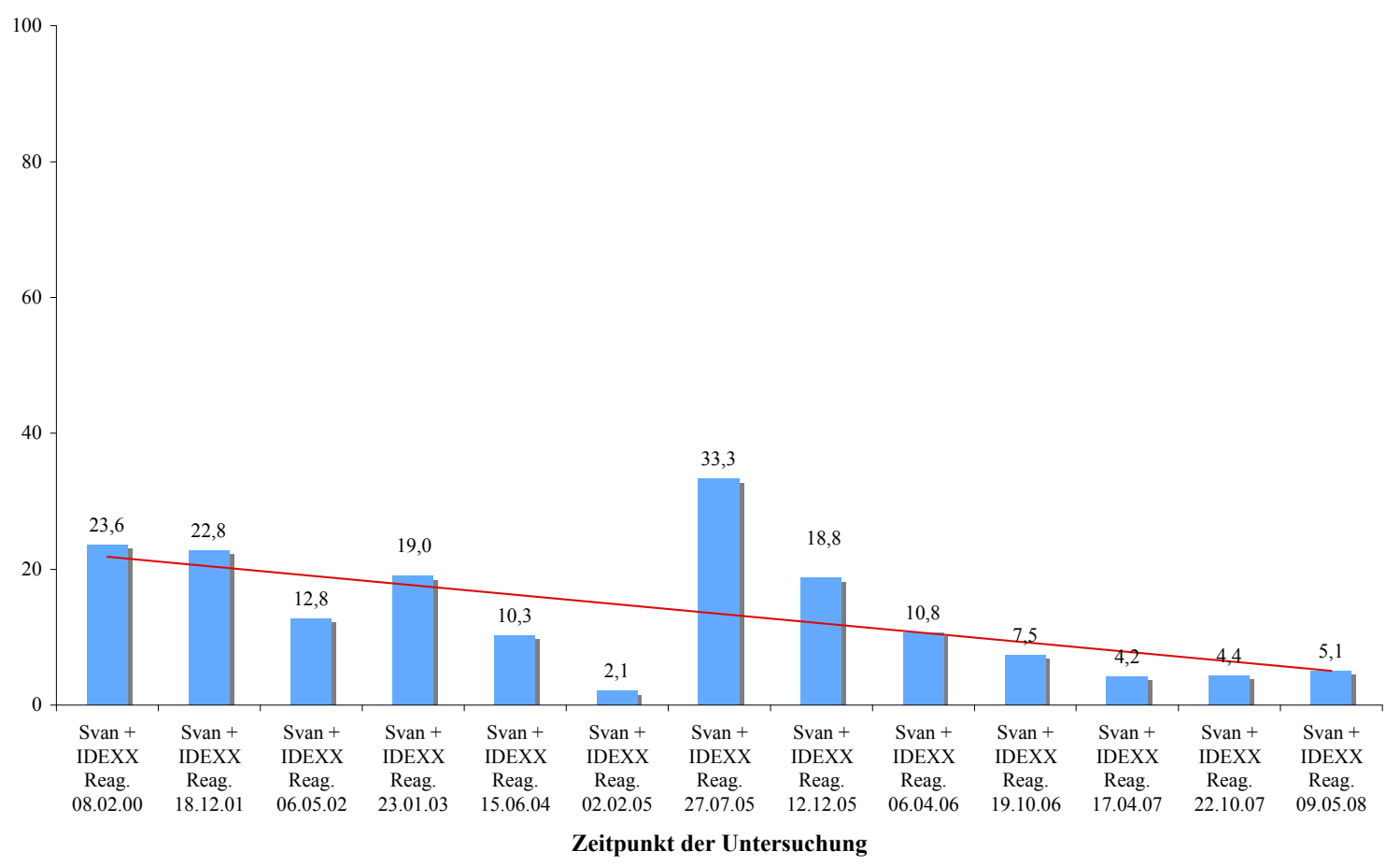

Abb. 14: Prozentualer Anteil der gleichzeitig im Svanovir- und IDEXX-ELISA reagierenden Tiere im Betrieb „H“

Nach dem Einfügen der Trendlinien in die Graphik für die IDEXX-ELISA-Reagenten ist zu erkennen, dass der prozentuale Anteil der Reagenten deutlich sinkt. Der prozentuale Anteil von Svanovir-ELISA-Reagenten sinkt auch, aber nicht im selben Maße wie beim IDEXXELISA. Der prozentuale Anteil von antikörperfreien Tieren im Betrieb steigt deutlich an. 


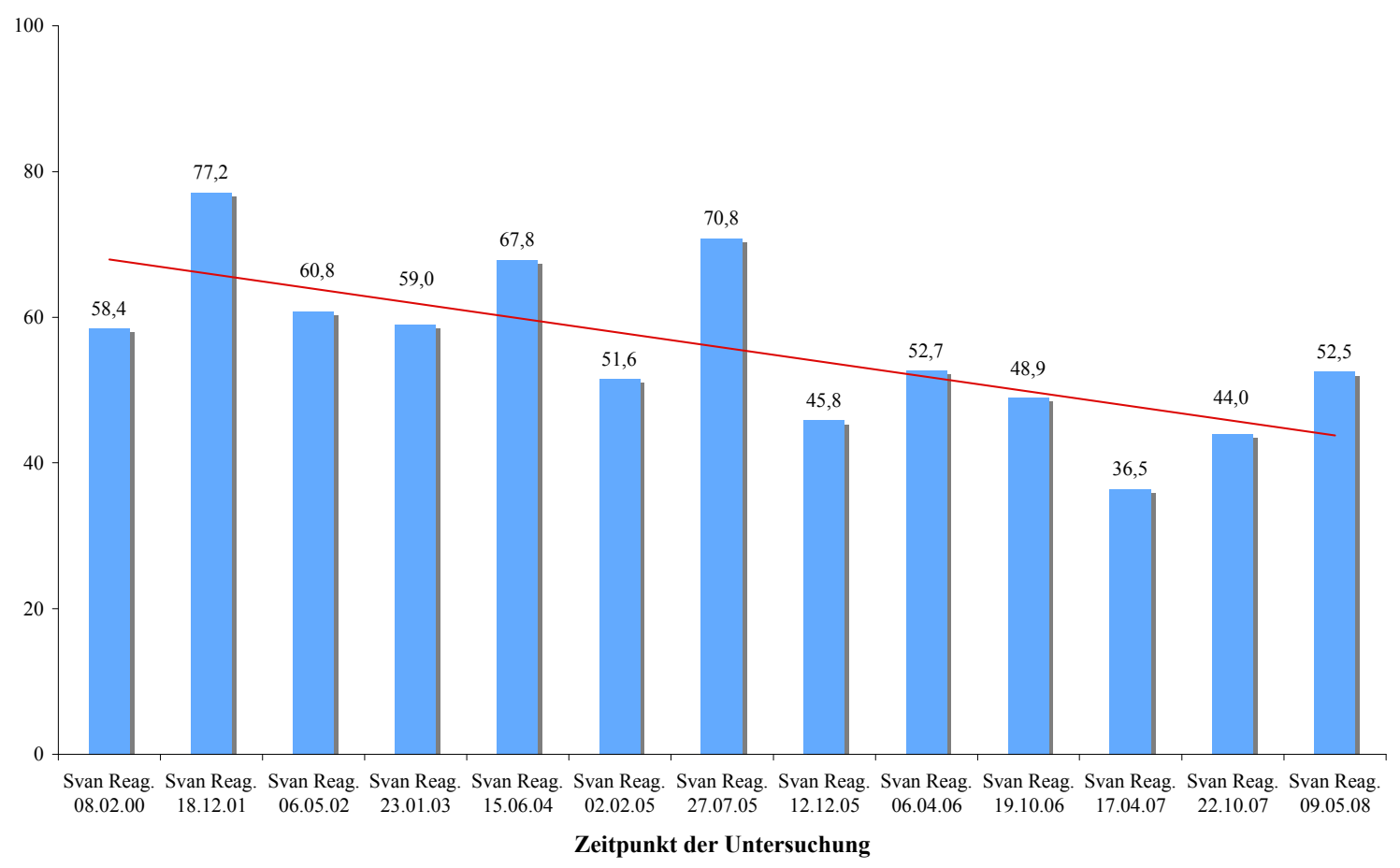

Abb. 15: Prozentualer Anteil der ausschließlich im Svanovir-ELISA reagierenden Tiere im Betrieb ,H““

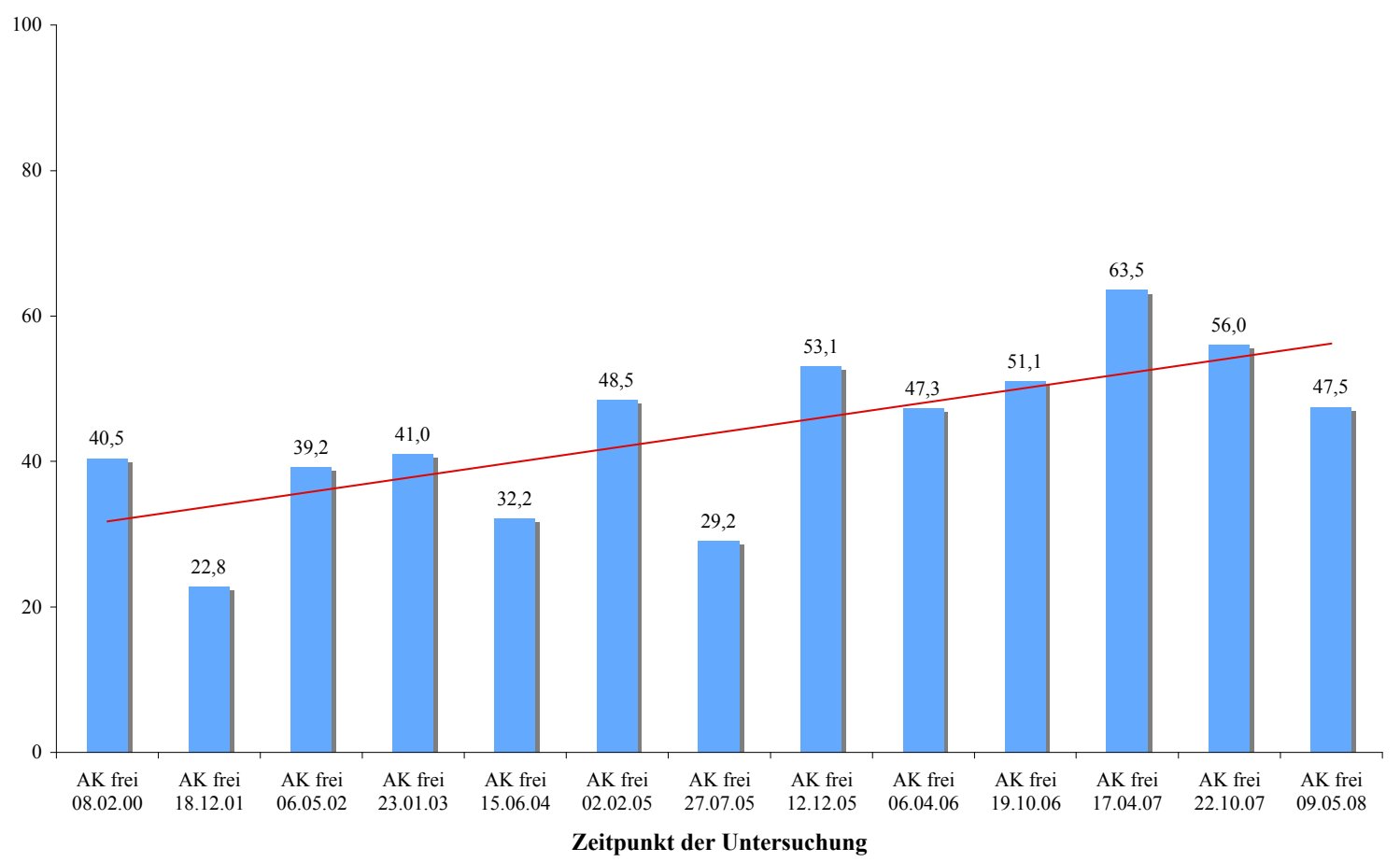

Abb. 16: Prozentualer Anteil der antikörperfreien Tiere im Betrieb „H“ 
In der untersuchten Altersgruppe der $\leq 4$ Jährigen waren am 08.02.2000 52 Tiere, am 18.12.2001 66 Tiere, am 06.05.2002 74 Tiere, am 23.01.2003 70 Tiere, am 15.06.2004 57 Tiere, am 02.02.2005 65 Tiere, am 27.07.2005 62 Tiere, am 12.12.2005 54 Tiere, am 06.04.2006 46 Tiere, am 19.10.2006 44 Tiere, am 17.04.2007 50 Tiere, am 22.10.2007 52 Tiere, sowie am 09.05.2008 65 Tiere Reagenten. Dies entspricht einem Anteil von 40,4\%, $71,2 \%, 54,1 \%, 48,6 \%, 63,2 \%, 35,4 \%, 59,7 \%, 29,6 \%, 43,5 \%, 38,6 \%, 18,0 \%, 26,9 \%, 43,1 \%$ an Svanovir-ELISA-Reagenten in der Herde.

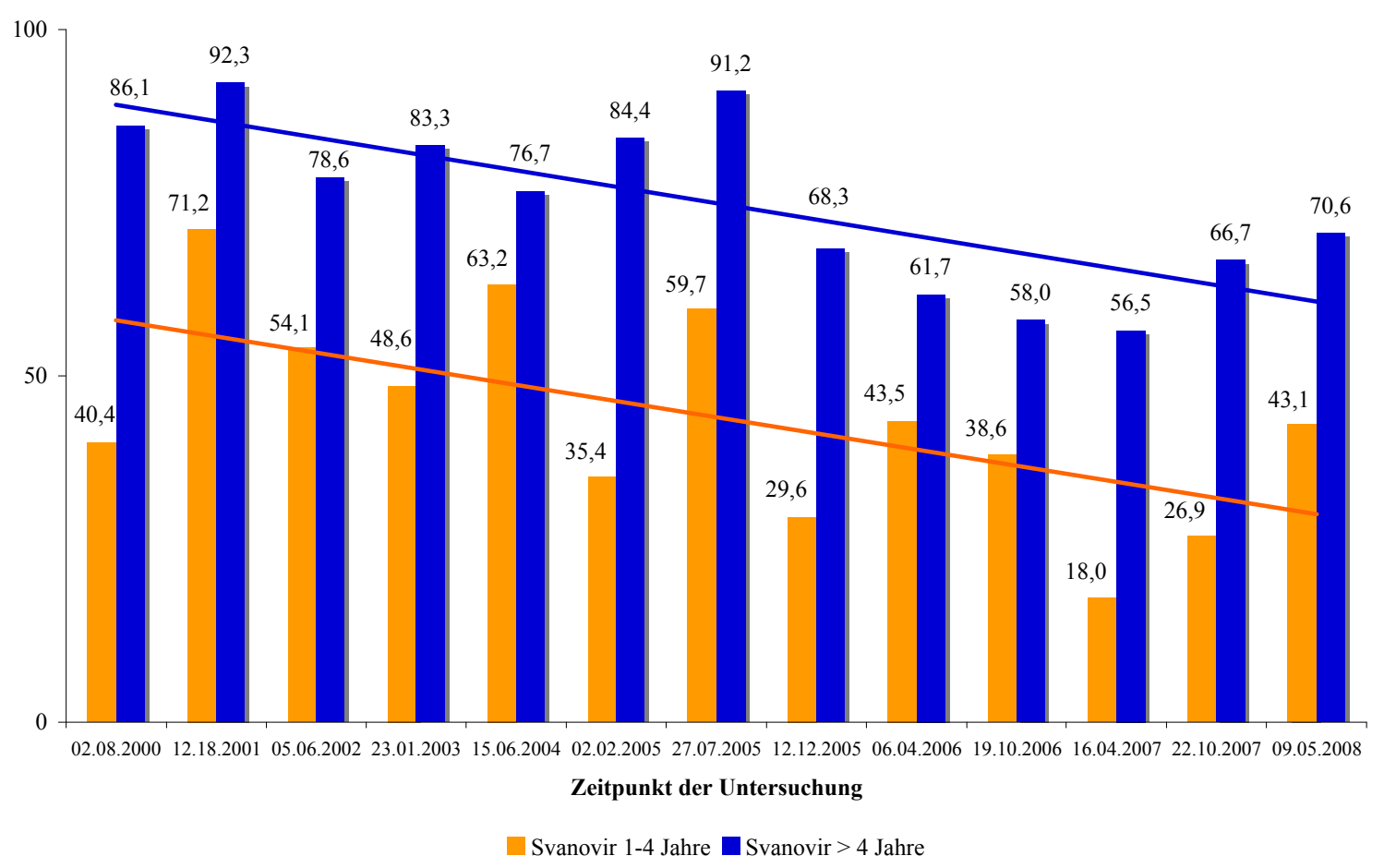

Abb. 17: Prozentualer Anteil der ausschließlich im Svanovir-ELISA reagierenden Tiere aus der Gruppe der $\leq 4$ und $>4$ jährigen Tiere im Betrieb „,H“

In der Gruppe der > 4 Jährigen wurden entsprechend 36, 26, 28, 30, 30, 32, 34, 41, 47, 50, 46, 39, 34 Tiere untersucht, davon waren $86,1 \%, 92,3 \%, 78,6 \%, 83,3 \%, 76,7 \%, 84,4 \%, 91,2 \%$, $68,3 \%, 61,7 \%, 58,0 \%, 56,5 \%, 66,7 \%, 70,6 \%$ der Tiere im Svanovir-ELISA Reagenten (Abb. 17). 


\subsubsection{2}

Ergebnisse im IDEXX-ELISA für die Altersgruppen $\leq 4$ Jahre und $>4$ Jahre

Von den untersuchten Tieren in der Altersgruppe der $\leq 4$ Jährigen am 08.02.2000, 52 Tiere, 18.12.2001, 66 Tiere, 06.05.2002, 74 Tiere, 23.01.2003, 70 Tiere,15.06.2004, 57 Tiere, 02.02.2005, 65 Tiere, 27.07.2005, 62 Tiere, 12.12.2005, 54 Tiere, 06.04.2006, 46 Tiere, 19.10.2006, 44 Tiere, 17.04.2007, 50 Tiere, 22.10.2007, 52 Tiere, 09.05.2008, 65 Tiere, waren jeweils $11,5 \%, 21,2 \%, 10,8 \%, 8,6 \%, 5,3 \%, 1,5 \%, 24,2 \%, 13,0 \%, 8,7 \%, 4,6 \%, 2,0 \%$, 3,9\%, 7,7\% der Tiere im IDEXX-ELISA-Reagenten. In der Gruppe $>4$ Jährigen wurden entsprechend 36, 26, 28, 30, 30, 32, 34, 41, 47, 50, 46, 39, 34 Tiere untersucht, davon waren $41,7 \%, 26,9 \%, 17,9 \%, 43,3 \%, 20,0 \%, 3,1 \%, 50,0 \%, 26,8 \%, 12,8 \%, 10,0 \%, 6,5 \%, 5,1 \%$ der Tiere im IDEXX-ELISA Reagenten. Am 09.05.2008 waren in der Gruppe der $>4$ jährigen Tiere keine IDEXX-ELISA-Reagenten mehr vorhanden (Abb. 18).

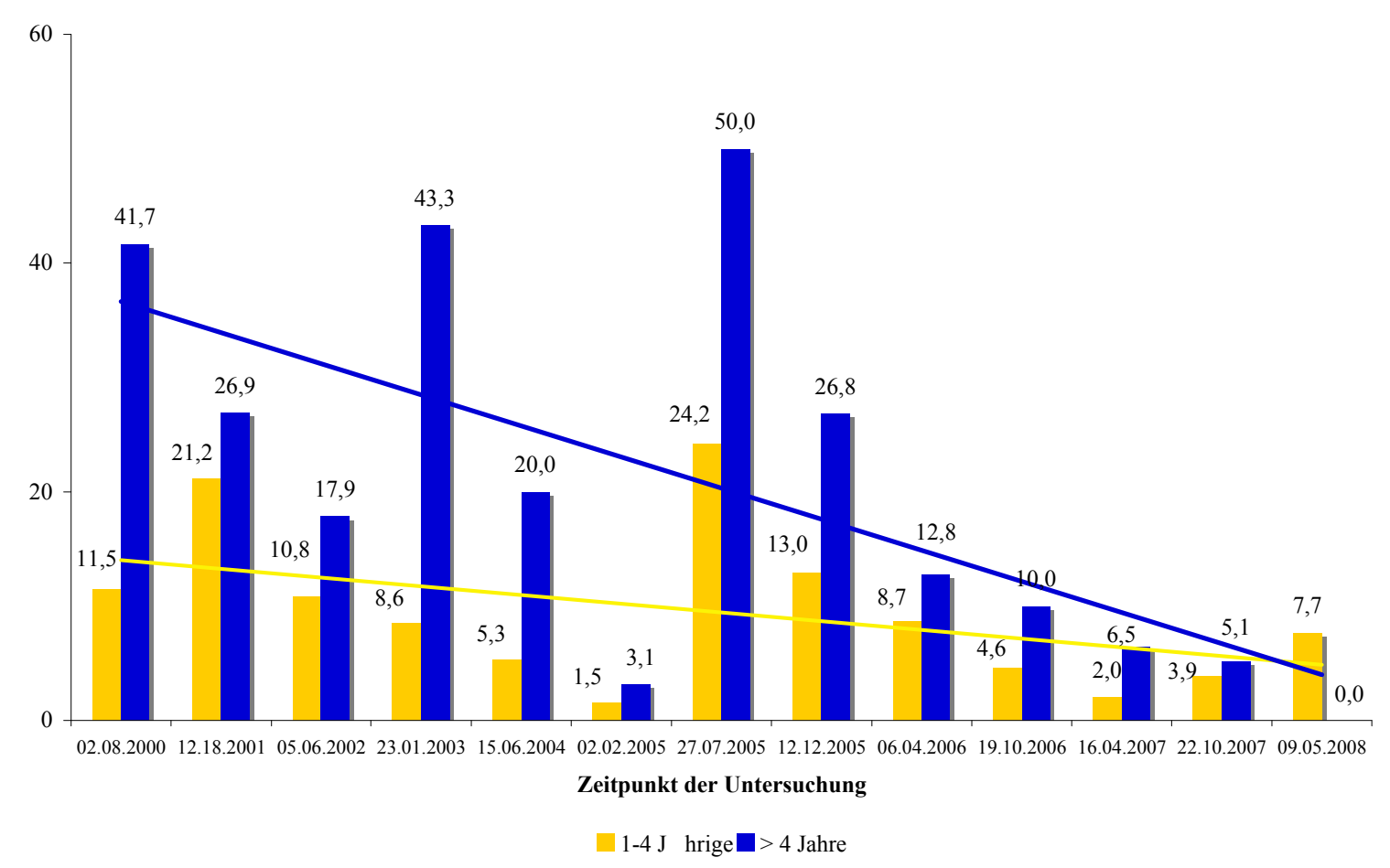

Abb. 18: Prozentualer Anteil der ausschließlich im IDEXX reagierenden Tiere aus der Gruppe der $\leq 4$ und $>4$ jährigen Tiere im Betrieb „,H“

\subsubsection{Serologischer Status der Zugänge}

Am 18.12.2001 wurden 58 Tiere (63,0\%) neu eingestellt, davon waren 11 Tiere sowohl im Svanovir- als auch im IDEXX-Test Reagenten. 3 Tiere davon waren positiv und 8 Tiere 
grenzbereichswertig. 32 Tiere waren Svanovir-Reagenten, davon waren 15 Tiere Svanovirpositiv, 17 Tiere lagen im Grenzbereich für Svanovir. 15 Tiere waren antikörperfrei.

Am 06.05.2002 wurden 29 Tiere $(28,4 \%)$ neu eingestellt, davon waren 2 Tiere sowohl im Svanovir- als auch im IDEXX-Test Reagenten. Davon war 1 Tier positiv und 1 Tier grenzbereichswertig. 5 Tiere waren Svanovir-Reagenten, davon waren 3 Tiere im Svanovir positiv, 2 Tiere lagen im Grenzbereich für Svanovir. 22 Tiere waren antikörperfrei.

Am 23.01.2003 wurden 26 Tiere (26,0\%) neu eingestellt, davon waren 8 Tiere SvanovirReagenten, 3 Tiere Svanovir positiv, 5 Tiere Svanovir grenzbereichswertig. 18 Tiere waren antikörperfrei.

Am 15.06.2004 wurden 44 Tiere (50,6\%) neu eingestellt, davon waren 2 Tiere sowohl im Svanovir- als auch im IDEXX-Test Reagenten. Die beiden Tiere waren grenzbereichswertig. 23 Tiere waren Svanovir-Reagenten, davon waren 10 Tiere Svanovir-positiv, 13 Tiere lagen im Grenzbereich für Svanovir. 19 Tiere waren antikörperfrei.

Am 02.02.2005 wurden 31 Tiere (32,0\%) neu eingestellt, 7 Tiere waren Svanovir-Reagenten davon waren 6 Tiere Svanovir-positiv, 1 Tier lag im Grenzbereich für Svanovir. 24 Tiere waren antikörperfrei.

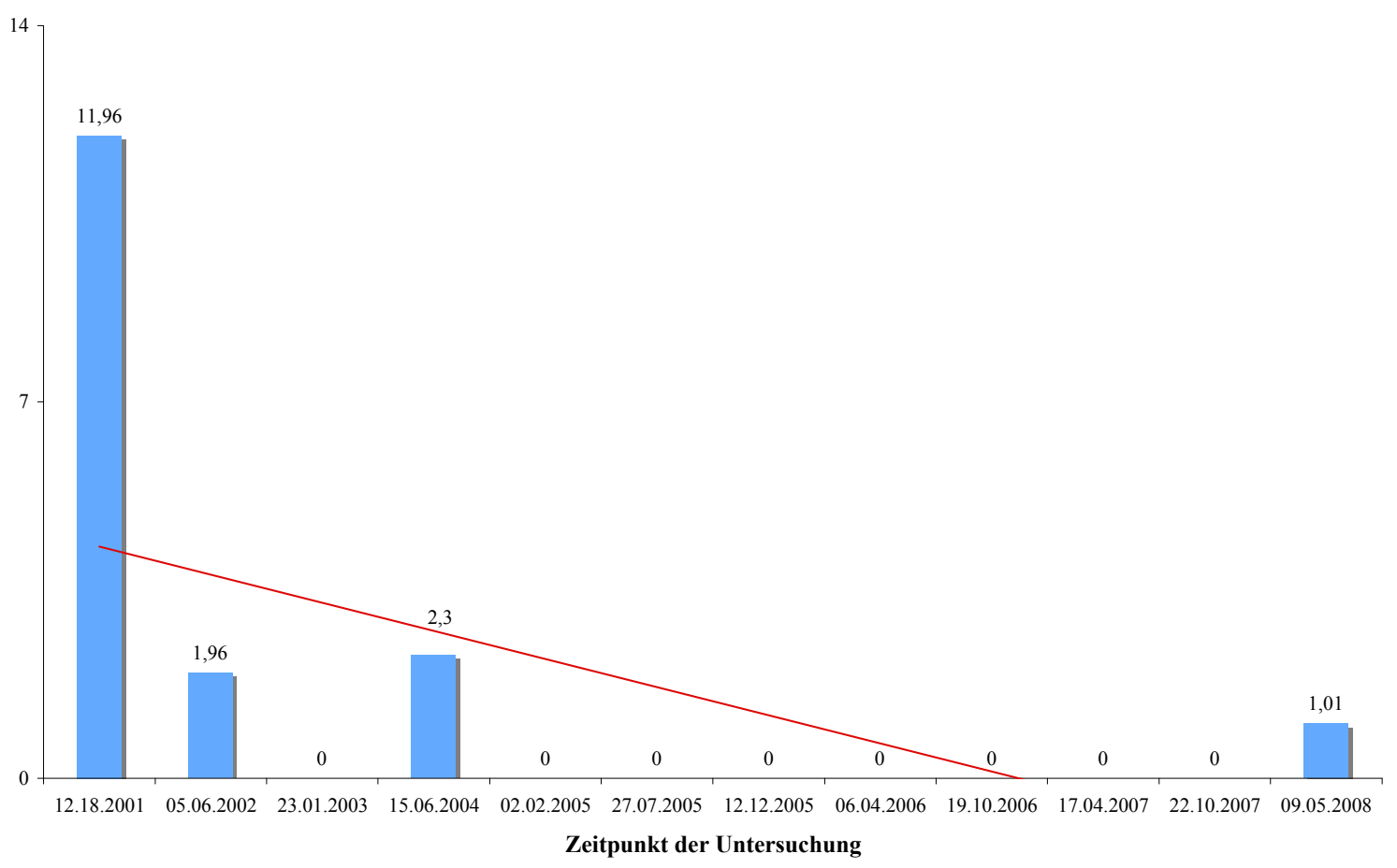

Abb. 19: Anteil der Bestandszugänge an der Herde in \%, der sowohl im IDEXX- als auch im Svanovir-ELISA reaktiv war 


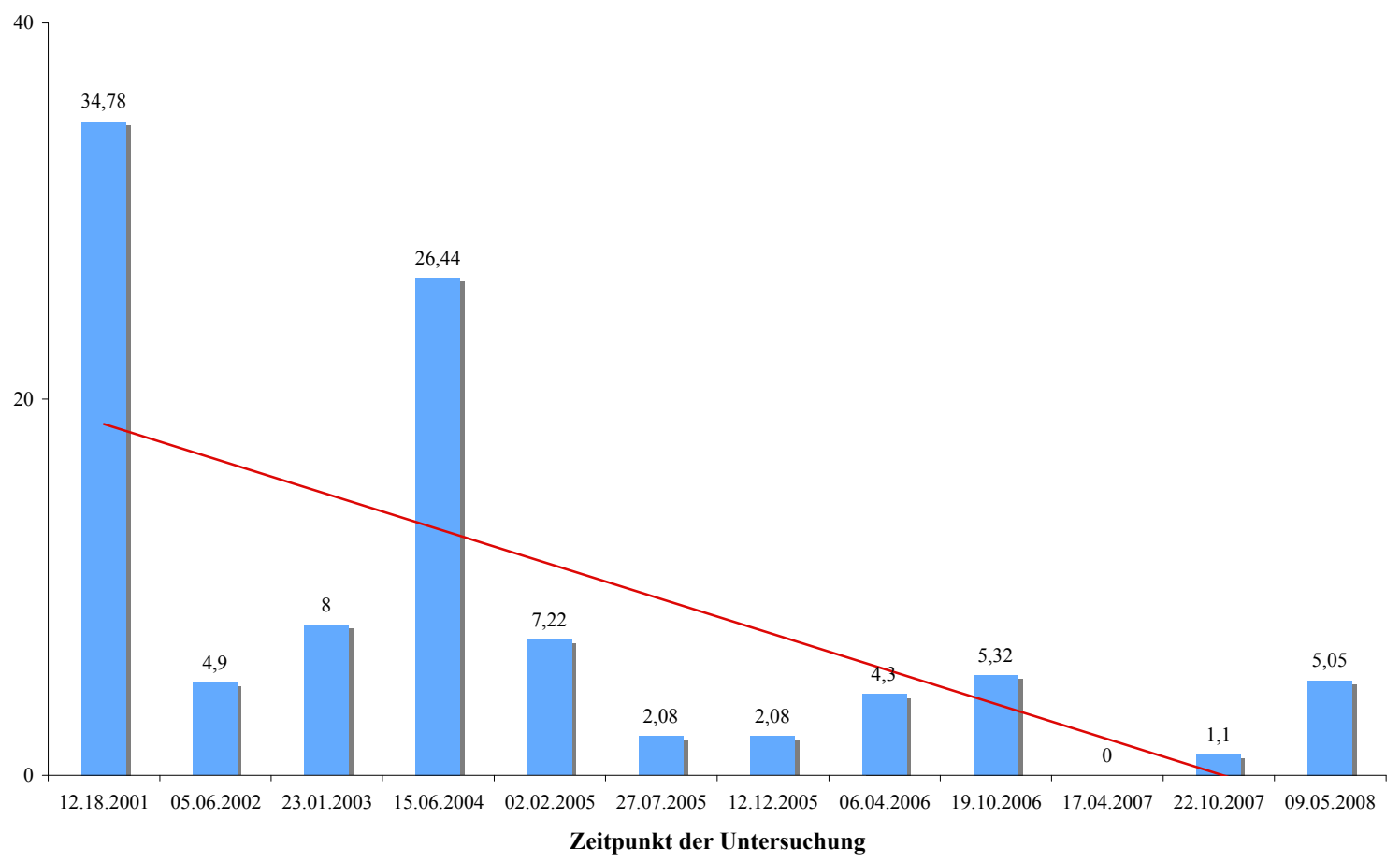

Abb. 20: Prozentualer Anteil der nur im Svanovir reagierenden Neuzugänge an der Herde

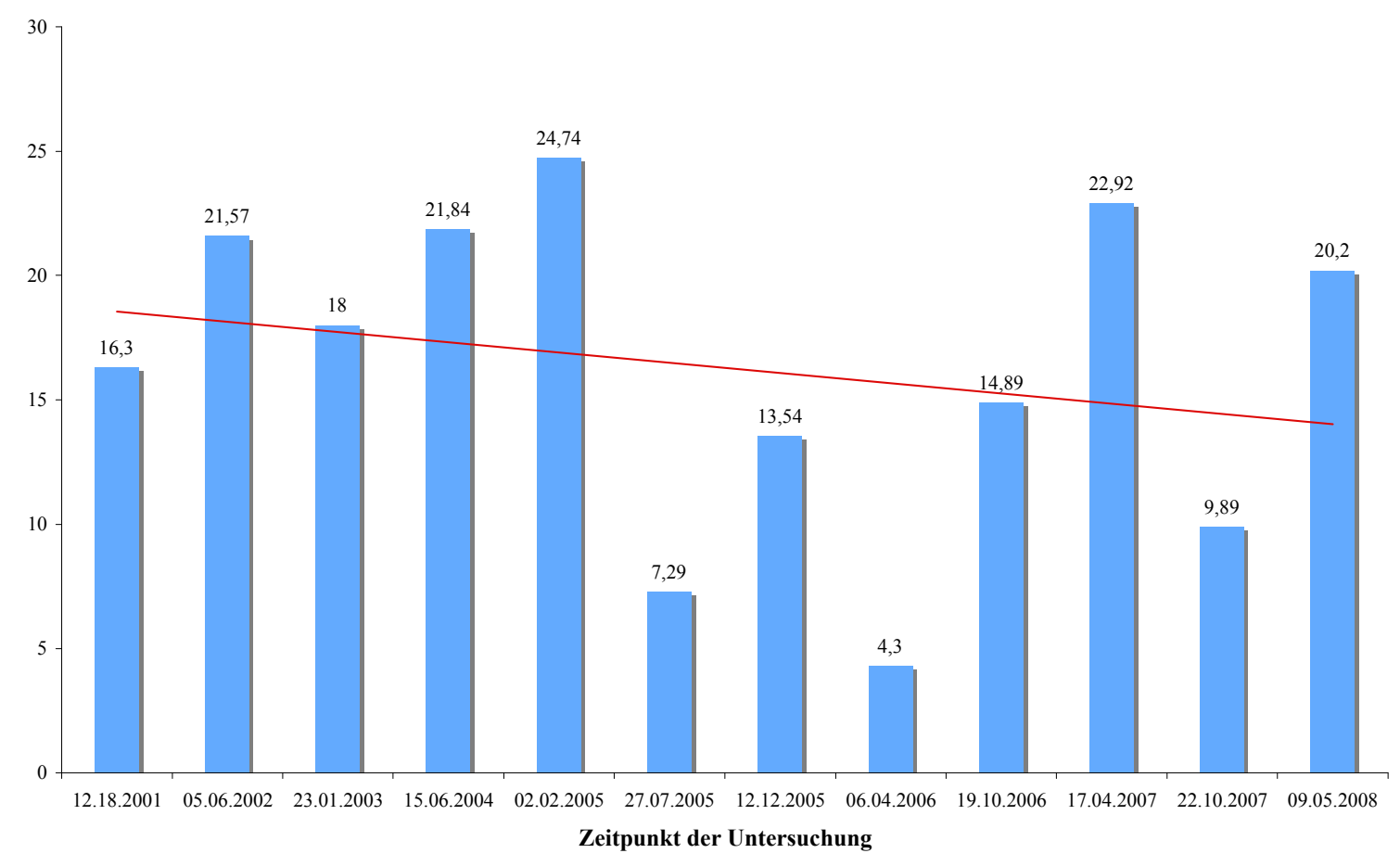

Abb. 21: Prozentualer Anteil der antikörperfreien Tiere, der durch die Neuzugänge gestellt wurde 
Am 27.07.2005 wurden 9 Tiere (9,4\%) neu eingestellt, 2 Tiere waren Svanovir-Reagenten davon war 1 Tier Svanovir-positiv, 1 Tier lag im Grenzbereich für Svanovir. 7 Tiere waren antikörperfrei.

Am 12.12. 2005 wurden 15 Tiere (15,6\%) neu eingestellt, 2 Tiere waren Svanovir-Reagenten (1 Tier Svanovir-positiv, 1 Tier lag im Grenzbereich). 12 Tiere waren antikörperfrei und 1 Tier gehörte zu der „unbekannter Status“ Gruppe.

Am 06.04.2006 wurden 8 Tiere $(8,6 \%)$ neu eingestellt, 4 Tiere waren Svanovir-Reagenten (3 Tiere Svanovir-positiv, 1 Tier im Grenzbereich für Svanovir), 4 Tiere waren antikörperfrei. Am 19.10.2006 wurden 19 Tiere (20,2\%) neu eingestellt. 5 Tiere waren Svanovir-Reagenten (3 Tiere Svanovir-positiv, 2 Tiere lagen im Grenzbereich. 14 Tiere waren antikörperfrei. Am 17.04.2007 wurden 22 Tiere (22,9\%) neu eingestellt, alle 22 Tiere waren antikörperfrei. Am 22.10.2007 wurden 10 Tiere $(11,0 \%)$ neu eingestellt, 1 Tier war Svanovirgrenzbereichswertig, 9 Tiere waren antikörperfrei.

Am 09.05.2008 wurden 26 Tiere (26,3\%) neu eingestellt, davon war 1 Tier sowohl im Svanovir- als auch im IDEXX-Test reaktiv, dieses war im IDEXX grenzbereichswertig. 5 Tiere waren Svanovir-Reagenten, davon waren 4 Tiere im Svanovir positiv, 1 Tier im Svanovir grenzbereichswertig. 20 Tiere waren antikörperfrei (Abb. 19-21).

\subsection{Zugänge, die Svanovir-Reagenten waren und später im IDEXX-ELISA reagiert haben}

Am 18.12.2001 waren von den gesamten Zugängen 32 Tiere im Svanovir-ELISA Reagenten. Davon sind im Laufe der Zeit 37,5\% zu IDEXX-Reagenten geworden. Am 06.05.2002 waren unter den Zugängen 5 Tiere Svanovir-ELISA Reagenten, davon sind 40,0\% der Tiere zu IDEXX-Reagenten geworden. Am 23.01.2003 waren unter den Zugängen 8 Svanovir-ELISAReagenten, davon sind 37,5\% der Tiere zu IDEXX-Reagenten geworden. Am 15.06.2004 waren unter den Zugängen 23 Svanovir-ELISA-Reagenten, davon sind 47,8\% der Tiere zu IDEXX-Reagenten geworden. Am 02.02.2005 waren unter den Zugängen 7 Svanovir-ELISAReagenten, davon sind 57,1\% der Tiere zu IDEXX-Reagenten geworden. Am 27.07.2005 waren unter den Zugängen 2 Tiere Svanovir-ELISA-Reagenten, davon sind 50,0\% der Tiere zu IDEXX-Reagenten geworden. Am 12.12.2005 waren unter den Zugängen 2 Tiere Svanovir-ELISA-Reagenten, davon sind 50,0\% der Tiere zu IDEXX-Reagenten geworden. 


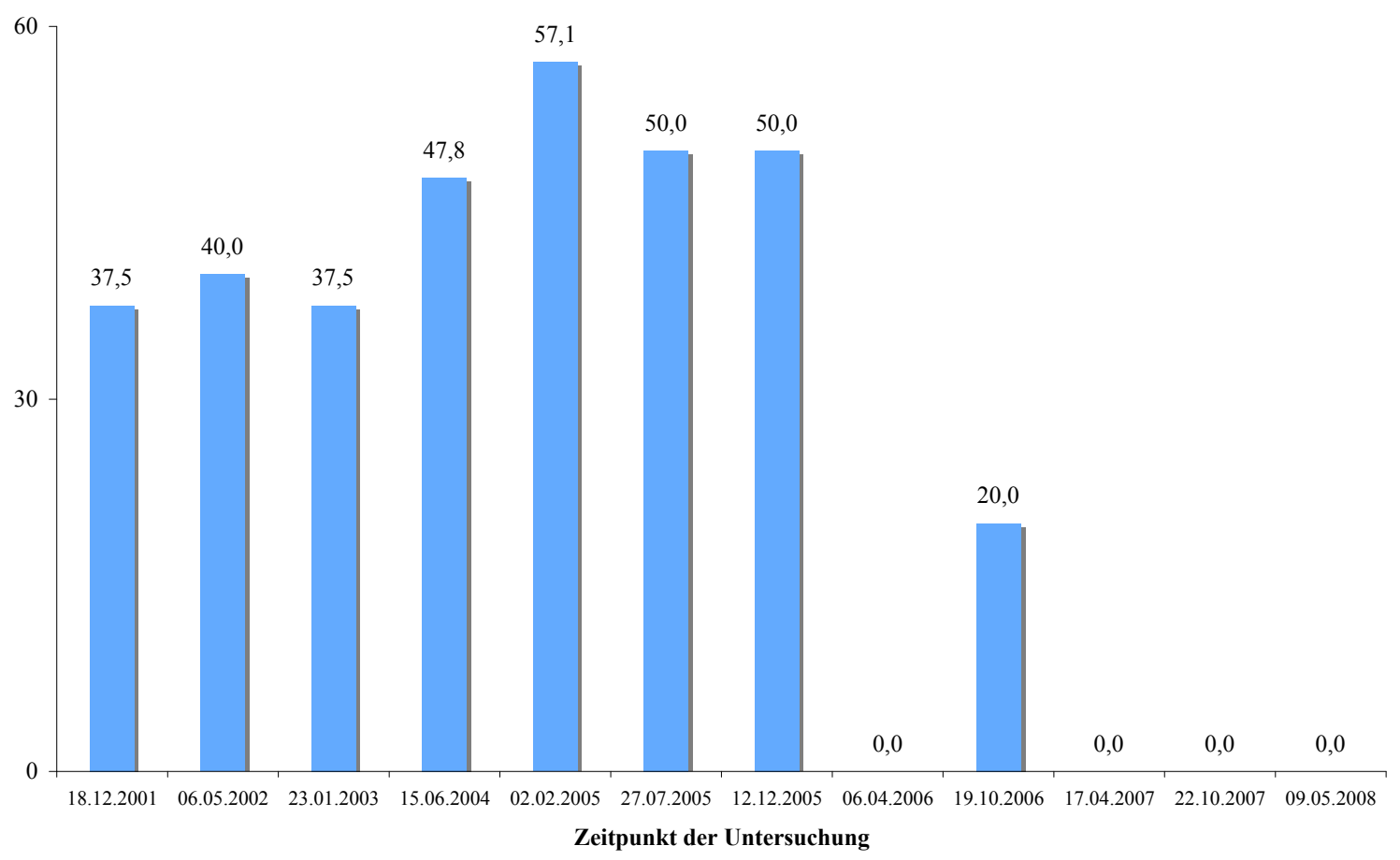

Abb. 22: Prozentualer Anteil der Neuzugänge, die bereits als Svanovir-reaktiv eingestallt wurden und später im IDEXX-ELISA reagiert haben

Am 06.04.2006 waren unter den Zugängen 4 Tiere Svanovir-ELISA-Reagenten, in den nachfolgenden Untersuchungen waren alle Tiere frühzeitig aus der Herde abgeschafft worden. Am 19.10.2006 waren unter den Zugängen 5 Tiere Svanovir-ELISA-Reagenten, davon sind 20,0\% der Tiere zu IDEXX-Reagenten geworden. Am 17.04.2007 waren unter den Zugängen keine Svanovir-ELISA-Reagenten. Am 22.10.2007 war unter den Zugängen nur 1 Tier Svanovir-ELISA-Reagent, in der nachfolgenden Untersuchung war dieses Tier noch nicht zum IDEXX-Reagenten geworden. Am 09.05.2008 waren unter den Zugängen 5 Tiere SvanovirELISA-Reagenten (Abb. 22).

\subsubsection{Serologischer Status der Abgänge}

Am 08.02.2000 wurden insgesamt 55 Tiere abgeschafft $(61,8 \%)$, davon waren 14 Tiere antikörperfrei. 19 abgeschaffte Tiere waren Svanovir-ELISA-Reagenten (12 Tiere positiv und 7 Tiere grenzbereichswertig). 21 Tiere waren sowohl im Svanovir- als auch im IDEXX-Test Reagenten, davon waren alle 21 Tiere IDEXX-positiv, 1 Tier hatte unbekannten Status. 


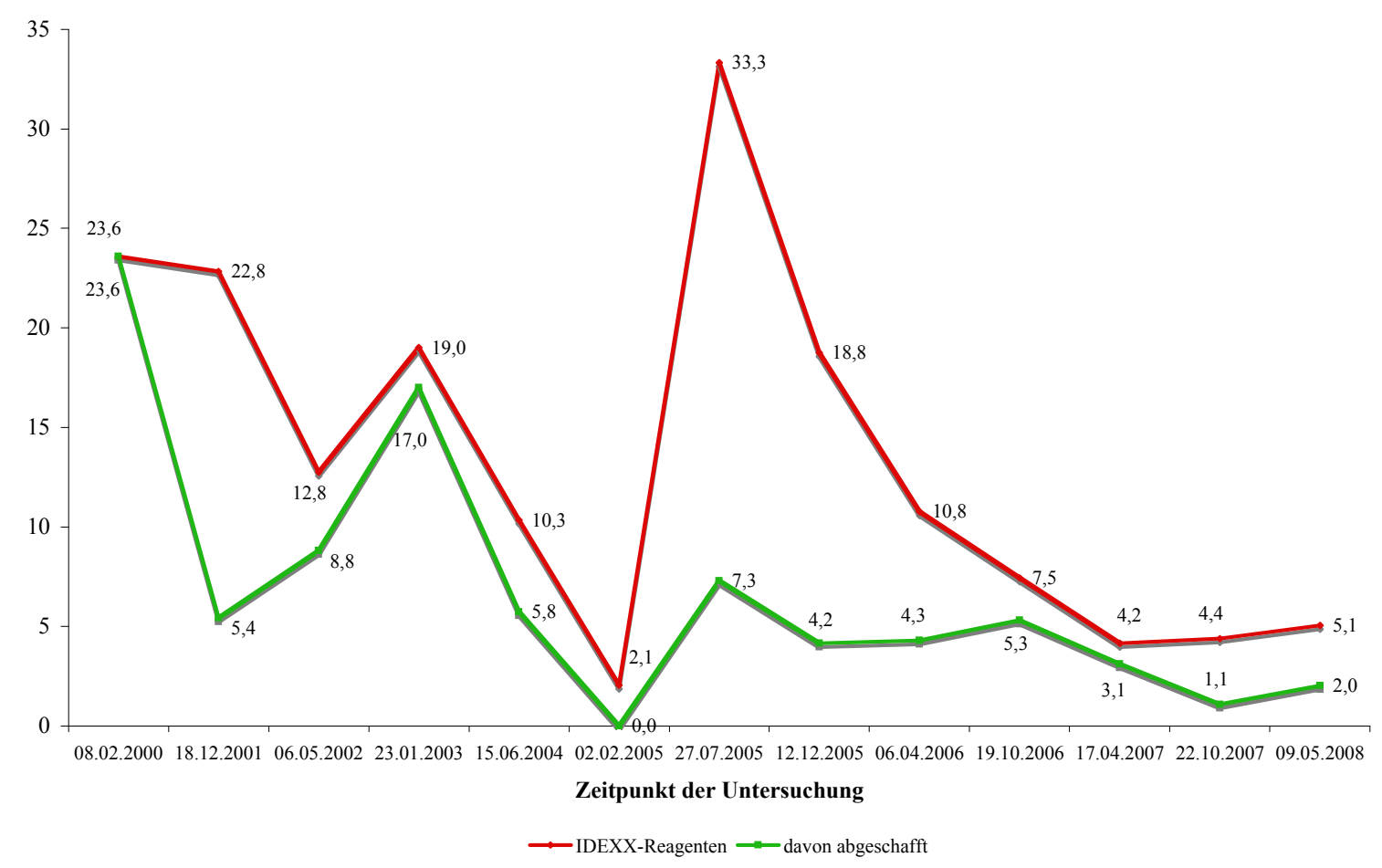

Abb. 23: Anteil der gleichzeitig im Svanovir- und IDEXX-ELISA reagierenden Tiere an der Herde, sowie Anteil der abgeschafften Tiere aus dieser Gruppe (In Bezug zur Herde)

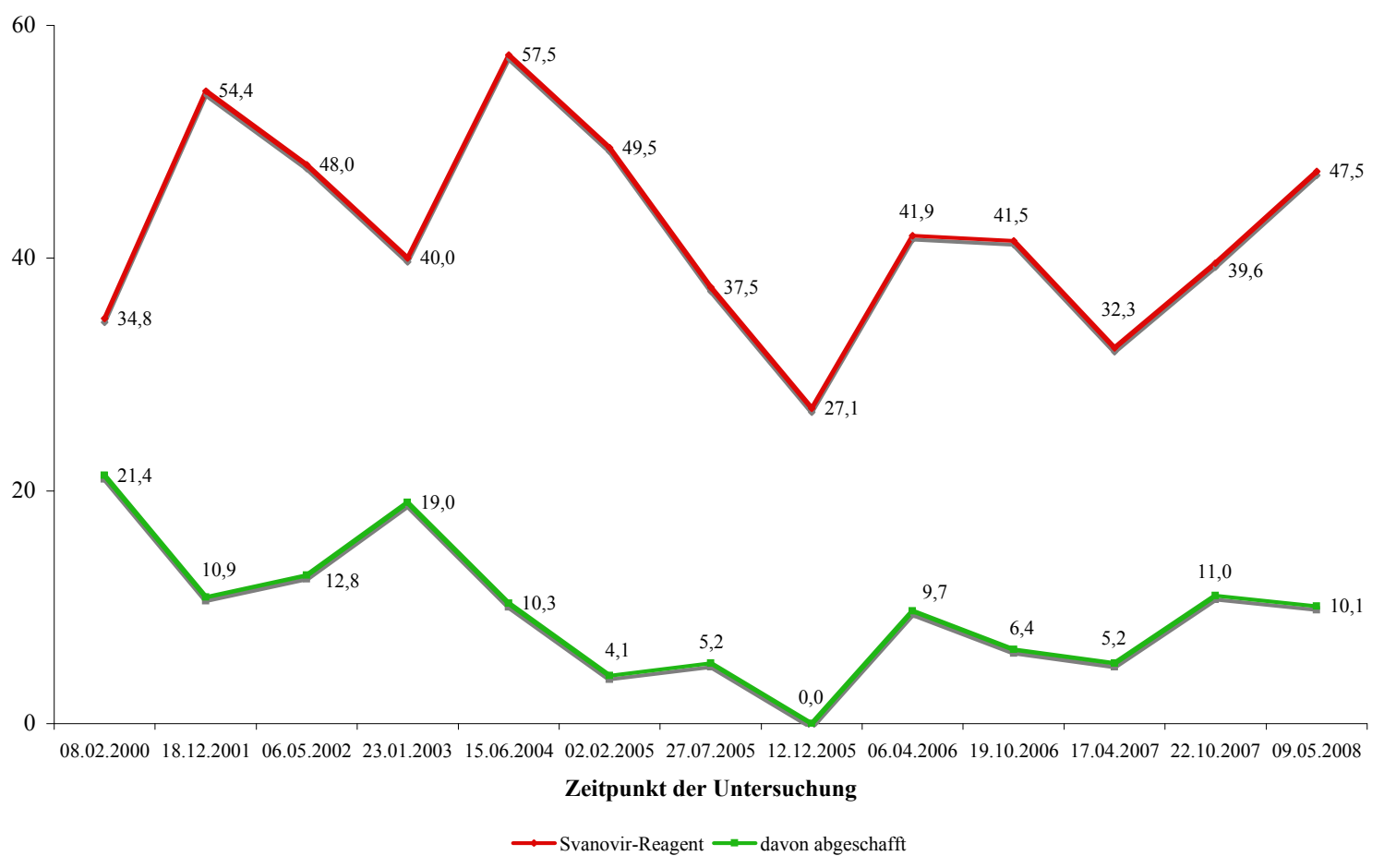

Abb. 24: Anteil der ausschließlich im Svanovir-ELISA reagierenden Tiere an der Herde, sowie Anteil der abgeschafften Tiere aus dieser Gruppe (In Bezug zur Herde) 
Am 18.12.2001 wurden insgesamt 19 Tiere abgeschafft (20,6\%), davon waren 4 Tiere antikörperfrei, 10 Tiere waren Svanovir-ELISA-Reagenten (5 Tiere positiv und 5 Tiere grenzbereichswertig).

5 Tiere waren sowohl im Svanovir- als auch im IDEXX-Test Reagenten, davon waren alle 5 Tiere IDEXX-positiv.

Am 06.06.2002 wurden insgesamt 28 Tiere abgeschafft (27,4\%), davon waren 6 Tiere antikörperfrei, 13 Tiere waren im Svanovir-ELISA Reagenten (9 Tiere positiv und 4 Tiere grenzbereichswertig). 9 Tiere waren sowohl im Svanovir- als auch im IDEXX-Test Reagenten (5 Tiere IDEXX-positiv und 4 Tiere IDEXX-grenzbereichswertig).

Am 23.01.2003 wurden von der Herde insgesamt 57 Tiere abgeschafft (57,0\%), davon waren 21 Tiere antikörperfrei und 19 Tiere waren Svanovir-ELISA-Reagenten (10 Tiere positiv und 9 Tiere grenzbereichswertig). 17 Tiere waren sowohl im Svanovir- als auch im IDEXX-Test Reagenten, davon waren 9 Tiere IDEXX-positiv und 8 Tiere IDEXX-grenzbereichswertig. Am 15.06.2004 wurden insgesamt 21 Tiere abgeschafft (24,1\%), davon waren 7 Tiere antikörperfrei, 9 Tiere waren Svanovir-ELISA-Reagenten (4 Tiere positiv und 5 Tiere grenzbereichswertig). 5 Tiere waren sowohl im Svanovir- als auch im IDEXX-Test Reagenten, davon waren 3 Tiere IDEXX-positiv und 2 Tiere IDEXX-grenzbereichswertig.

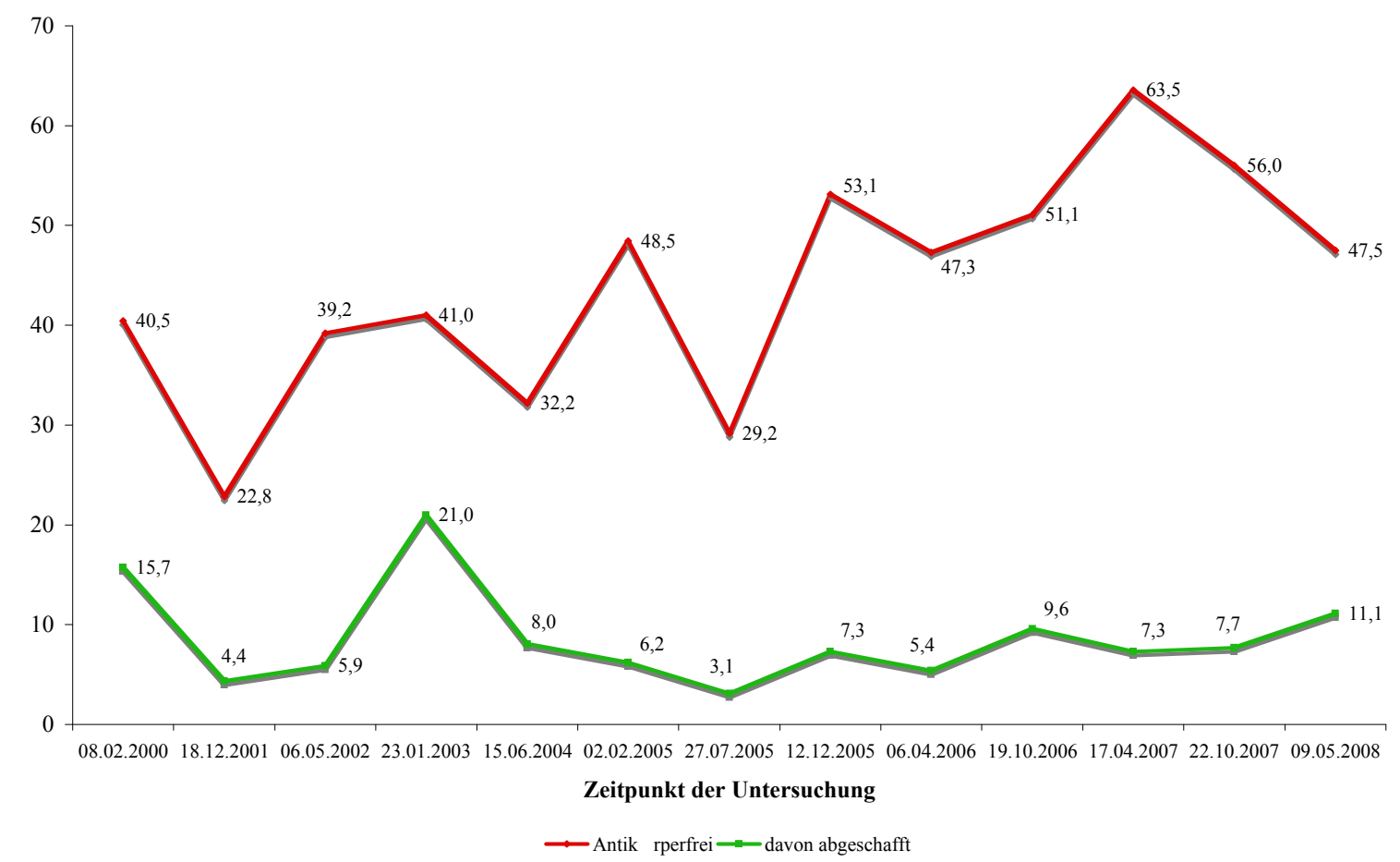

Abb. 25: Anteil der antikörperfreien Tiere an der Herde sowie Anteil der abgeschafften Tiere aus dieser Gruppe (In Bezug zur Herde) 
Am 02.02.2005 wurden insgesamt 10 Tiere abgeschafft (10,3\%), davon waren 6 Tiere antikörperfrei, 4 Tiere waren Svanovir-ELISA-Reagenten (3 Tiere positiv und 1 Tier grenzbereichswertig).

Am 27.07.2005 wurden insgesamt 15 Tiere abgeschafft (15,6\%), davon waren 3 Tiere antikörperfrei, 5 Tiere waren Svanovir-ELISA-Reagenten (2 Tiere positiv und 3 Tiere grenzbereichswertig). 7 Tiere waren sowohl im Svanovir- als auch im IDEXX-Test Reagenten (4 Tiere IDEXX-positiv und 3 Tiere IDEXX-grenzbereichswertig).

Am 12.12.2005 wurden insgesamt 11 Tiere abgeschafft $(11,5 \%)$, davon waren 7 Tiere antikörperfrei, 4 Tiere waren sowohl im Svanovir- als auch im IDEXX-Test Reagenten (2 Tiere IDEXX-positiv und 2 Tiere IDEXX-grenzbereichswertig).

Am 06.04.2006 wurden insgesamt 18 Tiere abgeschafft (19,4\%), davon waren 5 Tiere antikörperfrei, 9 Tiere waren Svanovir-ELISA-Reagenten $(8$ Tiere positiv und 1 Tier grenzbereichswertig). 4 Tiere waren sowohl im Svanovir- als auch im IDEXX-Test Reagenten, davon waren 3 Tiere IDEXX-positiv und 1 Tier IDEXX-grenzbereichswertig.

Am 19.10.2006 wurden insgesamt 20 Tiere abgeschafft (21,3\%), davon waren 9 Tiere antikörperfrei, 6 Tiere waren Svanovir-ELISA-Reagenten (3 Tiere positiv und 3 Tiere grenzbereichswertig). 5 Tiere waren sowohl im Svanovir- als auch im IDEXX-Test Reagenten (4 Tiere IDEXX-positiv und 1 Tier IDEXX-grenzbereichswertig).

Am 17.04.2007 wurden insgesamt 15 Tiere abgeschafft (15,6\%), davon waren 7 Tiere antikörperfrei, 5 Tiere waren Svanovir- ELISA-Reagenten (2 Tiere positiv und 3 Tiere grenzbereichswertig). 3 Tiere waren sowohl im Svanovir- als auch im IDEXX-Test Reagenten, davon war 1 Tier IDEXX-positiv und 2 Tiere IDEXX-grenzbereichswertig. Am 22.10.2007 wurden insgesamt 18 Tiere abgeschafft (19,8\%), davon waren 7 Tiere antikörperfrei und 10 Tiere Svanovir-ELISA-Reagenten (9 Tiere positiv und 1 Tier Svanovir- grenzbereichswertig). 1 Tier war sowohl im Svanovir- als auch im IDEXX-Test Reagent, dieses war IDEXX-positiv. Am 09.05.2008 wurden insgesamt 23 Tiere abgeschafft (23,2\%), davon waren 11 Tiere antikörperfrei, 10 Tiere Svanovir-ELISA-Reagenten (6 Tiere positiv und 4 Tier Svanovirgrenzbereichswertig), 2 Tiere waren sowohl im Svanovir- als auch im IDEXX-Test Reagenten, davon war 1 Tier IDEXX-positiv und 1 Tier IDEXX-grenzbereichswertig (Abb. 23-25).

\subsubsection{Ermittlung des Infektionsdrucks in verschiedenen Altersgruppen}

Um auf serologischer Basis den Infektionsdruck zu bestimmen, wurden die Tiere in verschiedene Altersgruppen aufgeteilt. Für die entsprechenden Altersgruppen wurden serologische 
Messwerte summiert und durch die Anzahl der Tiere dividiert. Es wurden folgende Altersgruppen gebildet: a) Tiere $\leq 4$ Jahre, b) Tiere $>4$ Jahre (Abb. 27 bis 29). Für den Gesamtbestand wurde ebenfalls der Mittelwert gebildet.

\subsubsection{Auf der Basis der Svanovir-ELISA-Messwerte errechnete Mittelwerte}

\subsection{Für die Gruppe a) Tiere $\leq 4$ Jahre}

Am 08.02.2000 wurden insgesamt 89 Tiere untersucht, davon waren 52 Tiere bis vier Jahre alt. In dieser Gruppe betrug der Wert des Svanovir-ELISAs 33,7\%. Am 18.12.2001 wurden insgesamt 92 Tiere untersucht, davon waren 66 Tiere bis vier Jahre alt. In dieser Gruppe betrug der Wert des Svanovir-ELISAs 60,0\%. Am 06.05.2002 wurden insgesamt 102 Tiere untersucht, davon waren 74 Tiere bis vier Jahre alt. In dieser Gruppe betrug der Wert des Svanovir-ELISAs 50,1\%. Am 23.01.2003 wurden insgesamt 100 Tiere untersucht, davon waren 70 Tiere bis vier Jahre alt. In dieser Gruppe betrug der Wert des Svanovir-ELISAs 37,9\%. Am 15.06.2004 wurden insgesamt 87 Tiere untersucht, davon waren 57 Tiere bis vier Jahre alt. In dieser Gruppe betrug der Wert des Svanovir-ELISAs 51,7\%. Am 02.02.2005 wurden insgesamt 97 Tiere untersucht, davon waren 65 Tiere bis vier Jahre alt. In dieser Gruppe betrug der Wert des Svanovir-ELISAs 40,9\%. Am 27.07.2005 wurden insgesamt 96 Tiere untersucht, davon waren 62 Tiere bis vier Jahre alt. In dieser Gruppe betrug der Wert des SvanovirELISA 59,2\%. Am 12.12.2005 wurden insgesamt 96 Tiere untersucht, davon waren 55 Tiere bis vier Jahre alt. In dieser Gruppe betrug der Wert des Svanovir-ELISAs 29,2\%. Am 06.04.2006 wurden insgesamt 93 Tiere untersucht, davon waren 46 Tiere bis vier Jahre alt. In dieser Gruppe betrug der Wert des Svanovir-ELISAs 38,4\%. Am 19.10.2006 wurden insgesamt 94 Tiere untersucht, davon waren 44 Tiere bis vier Jahre alt. In dieser Gruppe betrug der Wert des Svanovir-ELISAs 34,7\%. Am 17.04.2007 wurden insgesamt 96 Tiere untersucht, davon waren 50 Tiere bis vier Jahre alt. In dieser Gruppe betrug der Wert des SvanovirELISAs 21,6\%. Am 22.10.2007 wurden insgesamt 91 Tiere untersucht, davon waren 52 Tiere bis vier Jahre alt. In dieser Gruppe betrug der Wert des Svanovir-ELISAs 33,0\%. Am 09.05.2008 wurden insgesamt 99 Tiere untersucht, davon waren 65 Tiere bis vier Jahre alt. In dieser Gruppe betrug der Wert des Svanovir-ELISAs 41,2\% (Abb. 26). 


\subsection{Für die Gruppe b) Tiere $>4$ Jahre}

Am 08.02.2000 wurden insgesamt 89 Tiere untersucht, davon waren 37 Tiere älter als vier Jahre. In dieser Gruppe betrug der Wert des Svanovir-ELISAs 84,9\%. Am 18.12.2001 wurden insgesamt 92 Tiere untersucht, davon waren 26 Tiere älter als vier Jahre. In dieser Gruppe betrug der Wert des Svanovir-ELISAs 101,7\%. Am 06.05.2002 wurden insgesamt 102 Tiere untersucht, davon waren 28 Tiere älter als vier Jahre. In dieser Gruppe betrug der Wert des Svanovir-ELISAs 75,2\%. Am 23.01.2003 wurden insgesamt 100 Tiere untersucht, davon waren 30 Tiere älter als vier Jahre. In dieser Gruppe betrug der Wert des Svanovir-ELISAs 74,6\%. Am 15.06.2004 wurden insgesamt 87 Tiere untersucht, davon waren 30 Tiere älter als vier Jahre. In dieser Gruppe betrug der Wert des Svanovir-ELISAs 57,7\%. Am 02.02.2005 wurden insgesamt 97 Tiere untersucht, davon waren 32 Tiere älter als vier Jahre. In dieser Gruppe betrug der Wert des Svanovir-ELISAs 56,2\%. Am 27.07.2005 wurden insgesamt 96 Tiere untersucht, davon waren 34 Tiere älter als vier Jahre. In dieser Gruppe betrug der Wert des Svanovir-ELISAs 91,3\%. Am 12.12.2005 wurden insgesamt 95 Tiere untersucht, davon waren 41 Tiere älter als vier Jahre.

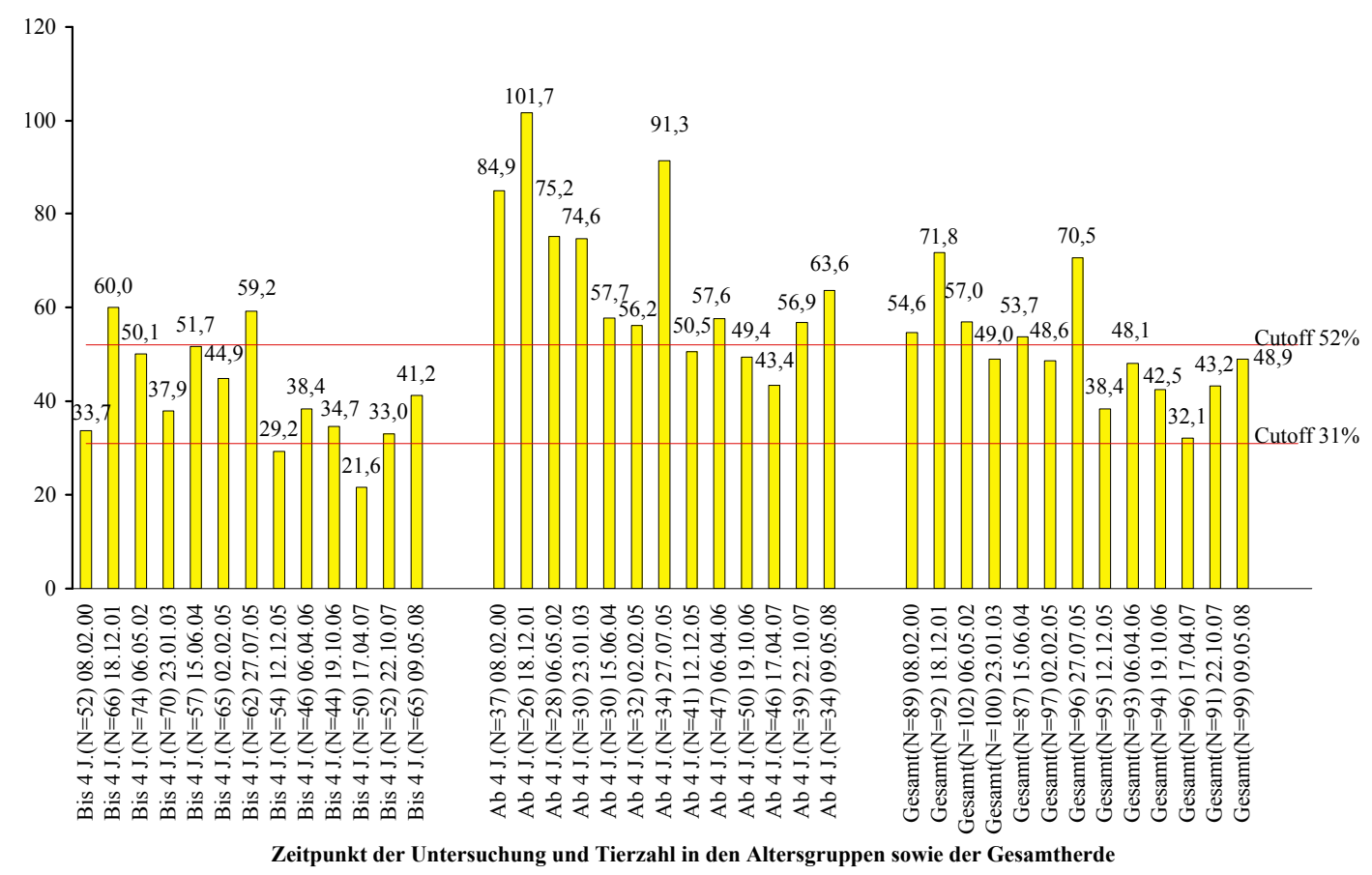

Abb. 26: Svanovir-ELISA: Darstellung des Infektionsdruckes in den Gruppen $\leq 4$ Jahre, $>4$ Jahre sowie der gesamten Herde anhand der errechneten ELISA-Mittelwerte 
In dieser Gruppe betrug der Wert des Svanovir-ELISAs 50,5\%. Am 06.04.2006 wurden insgesamt 93 Tiere untersucht, davon waren 47 Tiere älter als vier Jahre. In dieser Gruppe betrug der Wert des Svanovir-ELISAs 57,6\% Am 19.10.2006 wurden insgesamt 94 Tiere untersucht, davon waren 50 Tiere älter als vier Jahre. In dieser Gruppe betrug der Wert des SvanovirELISAs 49,4\%. Am 17.04.2007 wurden insgesamt 96 Tiere untersucht, davon waren 46 Tiere älter als vier Jahre. In dieser Gruppe betrug der Wert des Svanovir-ELISAs 43,4\%. Am 22.10.2007 wurden insgesamt 91 Tiere untersucht, davon waren 39 Tiere älter als vier Jahre. In dieser Gruppe betrug der Wert des Svanovir-ELISAs 56,9\%. Am 09.05.2008 wurden insgesamt 99 Tiere untersucht, davon waren 34 Tiere älter als vier Jahre. In dieser Gruppe betrug der Wert des Svanovir-ELISAs 63,6\% (Abb. 26).

\subsection{Mittelwerte des Svanovir-ELISAs für die gesamte Herde}

Am 08.02.2000 wurden insgesamt 89 Tiere untersucht. Für alle Tiere betrug der Mittelwert des Svanovir-ELISAs 54,6\%. Am 18.12.2001 wurden insgesamt 92 Tiere untersucht. In dieser Gruppe betrug der Wert des Svanovir-ELISAs 71,8\%. Am 06.05.2002 wurden insgesamt

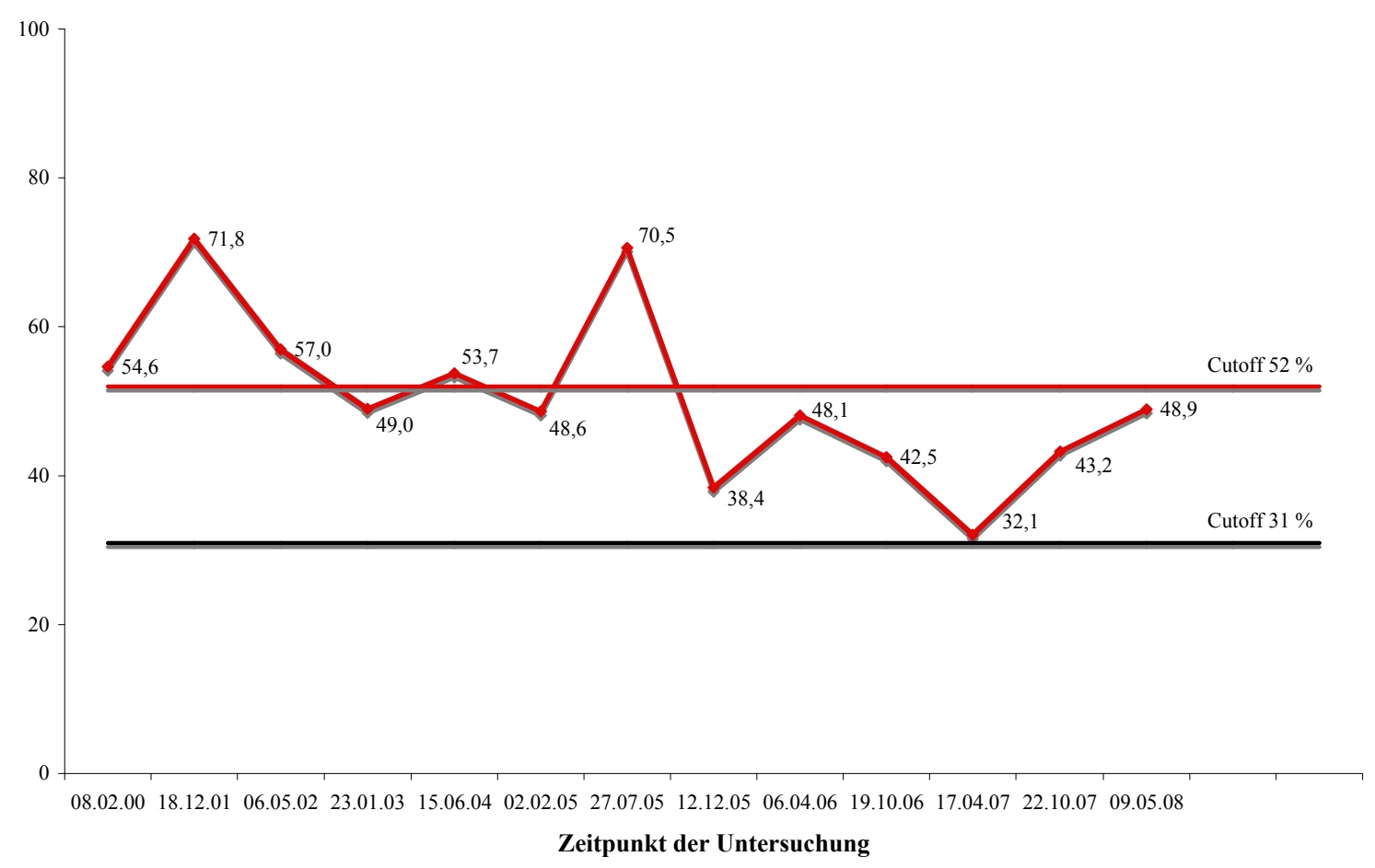

Abb. 27: Bestimmung des Sanierungserfolgs in der serologischen Herdenkontrolle durch Erhebung der mittleren Messwerte aller Tiere im Svanovir-ELISA 
102 Tiere untersucht. In dieser Gruppe betrug der Wert des Svanovir-ELISAs 57,0\%. Am 23.01.2003 wurden insgesamt 100 Tiere untersucht. In dieser Gruppe betrug der Wert des Svanovir-ELISAs 49,0\%. Am 15.06.2004 wurden insgesamt 87 Tiere untersucht. In dieser Gruppe betrug der Wert des Svanovir-ELISAs 53,7\%. Am 02.02.2005 wurden insgesamt 97 Tiere untersucht. In dieser Gruppe betrug der Wert des Svanovir-ELISAs 48,6\%. Am 27.07.2005 wurden insgesamt 96 Tiere untersucht. In dieser Gruppe betrug der Wert des Svanovir-ELISAs 70,5\%. Am 12.12.2005 wurden insgesamt 96 Tiere untersucht. In dieser Gruppe betrug der Wert des Svanovir-ELISAs 38,4\%. Am 06.04.2006 wurden insgesamt 93 Tiere untersucht. In dieser Gruppe betrug der Wert des Svanovir-ELISAs 48,1\%. Am 19.10.2006 wurden insgesamt 94 Tiere untersucht. In dieser Gruppe betrug der Wert des SvanovirELISAs 42,5\%. Am 17.04.2007 wurden insgesamt 96 Tiere untersucht. In dieser Gruppe betrug der Wert des Svanovir-ELISAs 32,1\%. Am 22.10.2007 wurden insgesamt 91 Tiere untersucht. In dieser Gruppe betrug der Wert des Svanovir-ELISAs 43,2\%. Am 09.05.2008 wurden insgesamt 99 Tiere untersucht. In dieser Gruppe betrug der Wert des Svanovir-ELISAs 48,9\% (Abb. 27).

\subsubsection{Auf Basis der IDEXX-ELISA-Messwerte errechnete Mittelwerte 4.1.3.2.1 Für die Gruppe a) Tiere $\leq 4$ Jahre}

Am 08.02.2000 wurden insgesamt 89 Tiere untersucht, davon waren 52 Tiere bis vier Jahre alt. In dieser Gruppe betrug der Wert des IDEXX-ELISAs 0,011\%. Am 18.12.2001 wurden insgesamt 92 Tiere untersucht, davon waren 66 Tiere bis vier Jahre alt. In dieser Gruppe betrug der Wert des IDEXX-ELISAs 0,115\%. Am 06.05.2002 wurden insgesamt 102 Tiere untersucht, davon waren 74 Tiere bis vier Jahre alt. In dieser Gruppe betrug der Wert des IDEXX-ELISAs 0,050\%. Am 23.01.2003 wurden insgesamt 100 Tiere untersucht, davon waren 70 Tiere bis vier Jahre alt. In dieser Gruppe betrug der Wert des IDEXX-ELISAs 0,035\%. Am 15.06.2004 wurden insgesamt 87 Tiere untersucht, davon waren 57 Tiere bis vier Jahre alt. In dieser Gruppe betrug der Wert des IDEXX-ELISAs 0,052\%. Am 02.02.2005 wurden insgesamt 97 Tiere untersucht, davon waren 65 Tiere bis vier Jahre alt. In dieser Gruppe betrug der Wert des IDEXX-ELISAs 0,011\%. Am 27.07.2005 wurden insgesamt 96 Tiere untersucht, davon waren 62 Tiere bis vier Jahre alt. In dieser Gruppe betrug der Wert des IDEXXELISAs 0,119\%. Am 12.12.2005 wurden insgesamt 96 Tiere untersucht, davon waren 55 Tiere bis vier Jahre alt. In dieser Gruppe betrug der Wert des IDEXX-ELISAs 0,058\%. Am 06.04.2006 wurden insgesamt 93 Tiere untersucht, davon waren 46 Tiere bis vier Jahre alt. In 
dieser Gruppe betrug der Wert des IDEXX-ELISAs 0,053\%. Am 19.10.2006 wurden insgesamt 94 Tiere untersucht, davon waren 44 Tiere bis vier Jahre alt. In dieser Gruppe betrug der Wert des IDEXX-ELISAs 0,056\%. Am 17.04.2007 wurden insgesamt 96 Tiere untersucht, davon waren 50 Tiere bis vier Jahre alt. In dieser Gruppe betrug der Wert des IDEXXELISAs -0,003\%. Am 22.10.2007 wurden insgesamt 91 Tiere untersucht, davon waren 52 Tiere bis vier Jahre alt. In dieser Gruppe betrug der Wert des IDEXX-ELISAs 0,004\%. Am 09.05.2008 wurden insgesamt 99 Tiere untersucht, davon waren 65 Tiere bis vier Jahre alt. In dieser Gruppe betrug der Wert des IDEXX-ELISAs -0,009\% (Abb. 28).

\subsection{Für die Gruppe b) Tiere $>4$ Jahre}

Am 08.02.2000 wurden insgesamt 89 Tiere untersucht, davon waren 37 Tiere älter als vier Jahre. In dieser Gruppe betrug der Wert des IDEXX-ELISAs 0,174\%. Am 18.12.2001 wurden insgesamt 92 Tiere untersucht, davon waren 26 Tiere älter als vier Jahre. In dieser Gruppe betrug der Wert des IDEXX-ELISA 0,130\%. Am 06.05.2002 wurden insgesamt 102 Tiere untersucht, davon waren 28 Tiere älter als vier Jahre. In dieser Gruppe betrug der Wert des

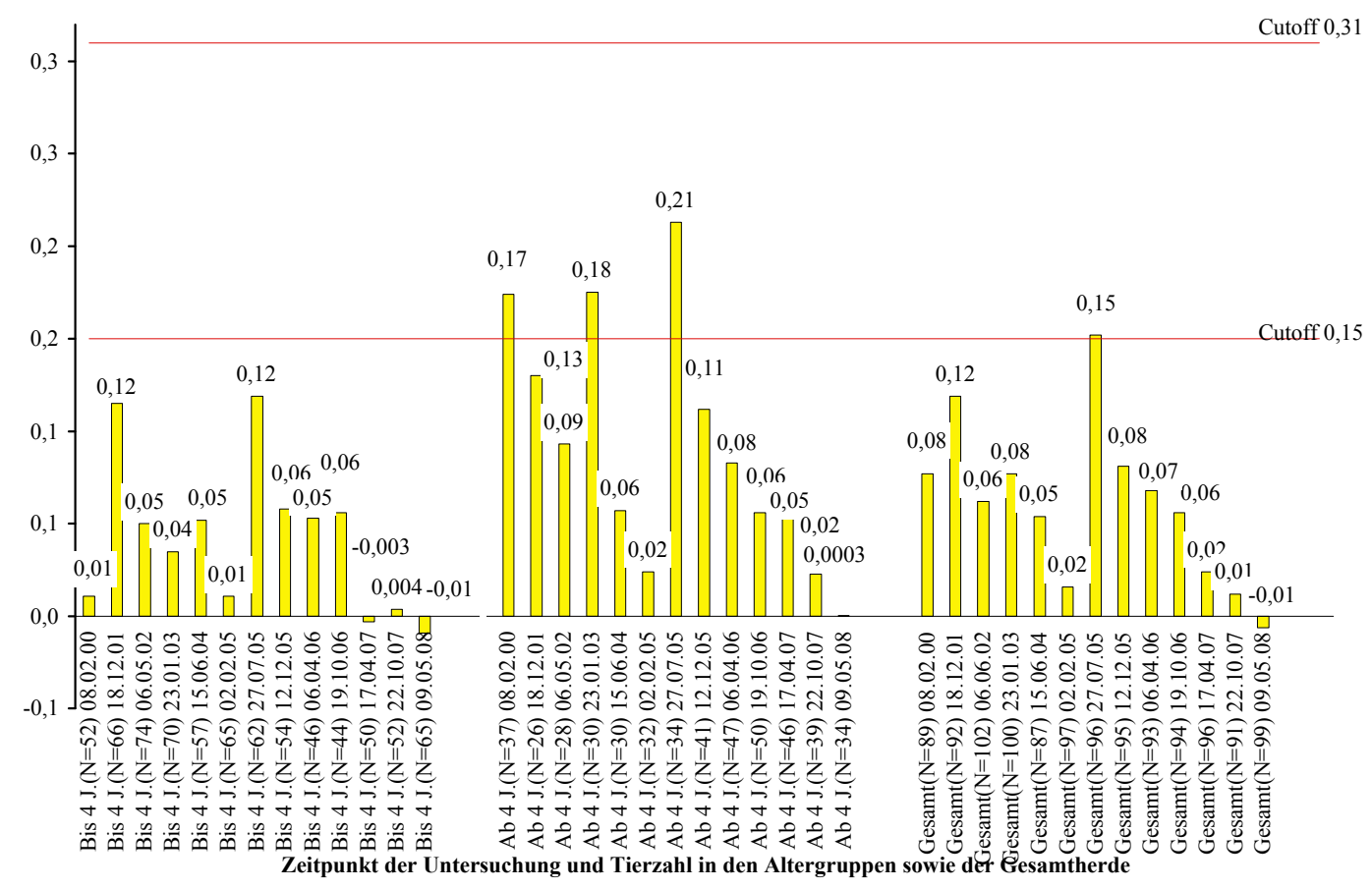

Abb. 28: IDEXX-ELISA: Darstellung des Infektionsdruckes in den Gruppen $\leq 4$ Jahre, $>4$ Jahre sowie der gesamten Herde anhand des gemittelten S/P- Verhältnisses 
IDEXX-ELISAs 0,93\%. Am 23.01.2003 wurden insgesamt 100 Tiere untersucht, davon waren 30 Tiere älter als vier Jahre.

In dieser Gruppe betrug der Wert des IDEXX-ELISAs 0,175\%. Am 15.06.2004 wurden insgesamt 87 Tiere untersucht, davon waren 30 Tiere älter als vier Jahre. In dieser Gruppe betrug der Wert des IDEXX-ELISAs 0,057\%. Am 02.02.2005 wurden insgesamt 97 Tiere untersucht, davon waren 32 Tiere älter als vier Jahre. In dieser Gruppe betrug der Wert des IDEXX-ELISAs 0,024\%. Am 27.07.2005 wurden insgesamt 96 Tiere untersucht, davon waren 34 Tiere älter als vier Jahre. In dieser Gruppe betrug der Wert des IDEXX-ELISAs 0,213\%. Am 12.12.2005 wurden insgesamt 95 Tiere untersucht, davon waren 41 Tiere älter als vier Jahre. In dieser Gruppe betrug der Wert des IDEXX-ELISAs 0,112\%. Am 06.04.2006 wurden insgesamt 93 Tiere untersucht, davon waren 47 Tiere älter als vier Jahre. In dieser Gruppe betrug der Wert des IDEXX-ELISAs 0,083\%. Am 19.10.2006 wurden insgesamt 94 Tiere untersucht, davon waren 50 Tiere älter als vier Jahre. In dieser Gruppe betrug der Wert des IDEXX-ELISAs 0,056\%. Am 17.04.2007 wurden insgesamt 96 Tiere untersucht, davon waren 46 Tiere älter als vier Jahre. In dieser Gruppe betrug der Wert des IDEXXELISAs 0,054\%. Am 22.10.2007 wurden insgesamt 91 Tiere untersucht, davon waren 39 Tiere älter als vier Jahre. In dieser Gruppe betrug der Wert des IDEXX-ELISAs 0,023\%. Am 09.05.2008 wurden insgesamt 99 Tiere untersucht, davon waren 34 Tiere älter als vier Jahre. In dieser Gruppe betrug der Wert des IDEXX-ELISAs 0,0003\% (Abb. 28).

\subsection{Mittelwerte im IDEXX-ELISA für die gesamte Herde}

Am 08.02.2000 wurden insgesamt 89 Tiere untersucht. In dieser Gruppe betrug der Wert des Svanovir-ELISAs 0,077\%. Am 18.12.2001 wurden insgesamt 92 Tiere untersucht. In dieser Gruppe betrug der Wert des Svanovir-ELISAs 0,119\%. Am 06.05.2002 wurden insgesamt 102 Tiere untersucht. In dieser Gruppe betrug der Wert des Svanovir-ELISAs 0,062\%. Am 23.01.2003 wurden insgesamt 100 Tiere untersucht. In dieser Gruppe betrug der Wert des Svanovir-ELISAs 0,077\%. Am 15.06.2004 wurden insgesamt 87 Tiere untersucht. In dieser Gruppe betrug der Wert des Svanovir-ELISAs 0,054\%. Am 02.02.2005 wurden insgesamt 97 Tiere untersucht. In dieser Gruppe betrug der Wert des Svanovir-ELISAs 0,016\%. Am 27.07.2005 wurden insgesamt 96 Tiere untersucht. In dieser Gruppe betrug der Wert des Svanovir-ELISAs 0,152\%. Am 12.12.2005 wurden insgesamt 96 Tiere untersucht. In dieser 


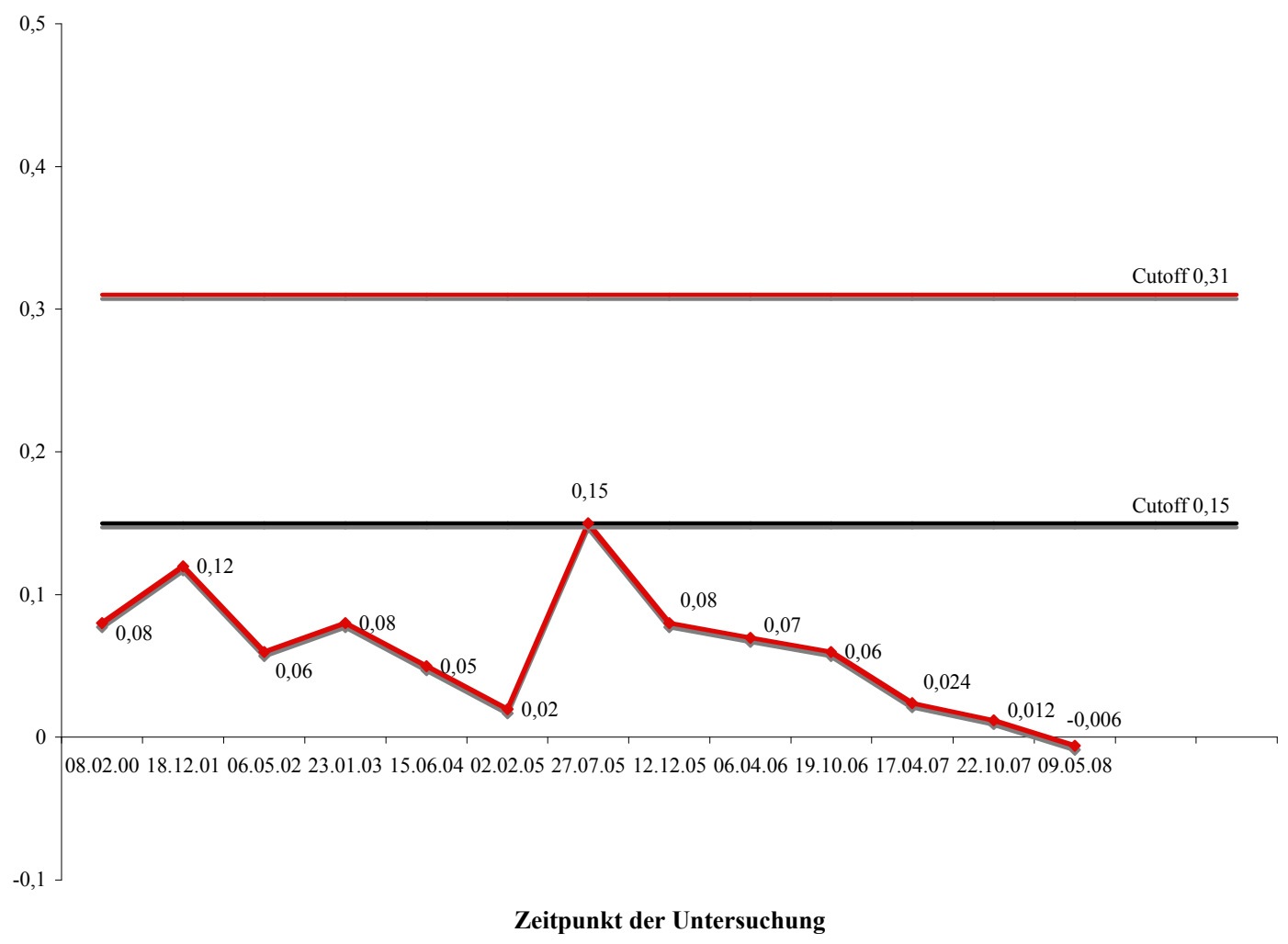

Abb. 29: Bestimmung des Sanierungserfolgs in der serologischen Herdenkontrolle durch Erhebung der mittleren Messwerte aller Tiere im IDEXX-ELISA

Gruppe betrug der Wert des Svanovir-ELISAs 0,081\%. Am 06.04.2006 wurden insgesamt 93 Tiere untersucht. In dieser Gruppe betrug der Wert des Svanovir-ELISAs 0,068\%. Am 19.10.2006 wurden insgesamt 94 Tiere untersucht. In dieser Gruppe betrug der Wert des Svanovir-ELISAs $0,056 \%$. Am 17.04.2007 wurden insgesamt 96 Tiere untersucht. In dieser Gruppe betrug der Wert des Svanovir-ELISAs 0,024\%. Am 22.10.2007 wurden insgesamt 91 Tiere untersucht. In dieser Gruppe betrug der Wert des Svanovir-ELISAs 0,012\%. Am 09.05.2008 wurden insgesamt 99 Tiere untersucht. In dieser Gruppe betrug der Wert des Svanovir-ELISAs $-0,006 \%$ (Abb. 29).

\subsubsection{Serologisch negative Erregerausscheider}

Im Bestand wurde durch gepoolte Kot-PCRs der Ausscheider-Status verschiedener serologischer Gruppen bestimmt.

Die Untersuchung von Kotproben am 19.10.06 mit der PCR zeigte, dass die Milchkühe mit der Ohrmarke 07347, 12645, 88797, 88807, 50482, 18707, 50506 Ausscheider waren, obwohl bei den Tieren serologisch kein Antikörpertiter nachweisbar war (Abb. 30). Bei der nächsten 
Untersuchung am 17.04.2007 waren die Tiere mit der Ohrmarke 07347 und 18707 aus der Herde abgeschafft worden. Der Milchkuh mit der Ohrmarke 88797 war wieder in der PCR Ausscheider, obwohl bei diesem Tiere serologisch kein Antikörper nachweisbar war. Die Tiere mit der Ohrmarke 88807, 50482 und 50506 schieden keinen MAP-Erreger mehr mit dem Kot aus und waren auch antikörperfrei. Die Milchkuh mit der Ohrmarke 12645 schied ebenffalls keinen MAP-Erreger mit dem Kot aus, war allerdings zum Svanovir-Reagenten geworden (Abb. 31). Zum 22.10.2007 wurde das Tier mit den Ohrmarken 88797 aus der Herde abgeschafft, die restlichen Tiere mit der Ohrmarke 12645, 88807, 50482, 50506 schieden mit dem Kot keinen MAP-Erreger mehr aus. Die Milchkuh mit der Ohrmarke 12645 blieb im Svanovir-ELISA reaktiv (Abb. 32). Die PCR-Untersuchung am 09.05.2008 zeigte, dass die Tiere mit der Ohrmarke 12645, 88807, 50482, 50506 keinen MAP-Erreger mit dem Kot ausschieden, jedoch alle zum Svanovir-ELISA-Reagenten geworden waren (Abb. 33).

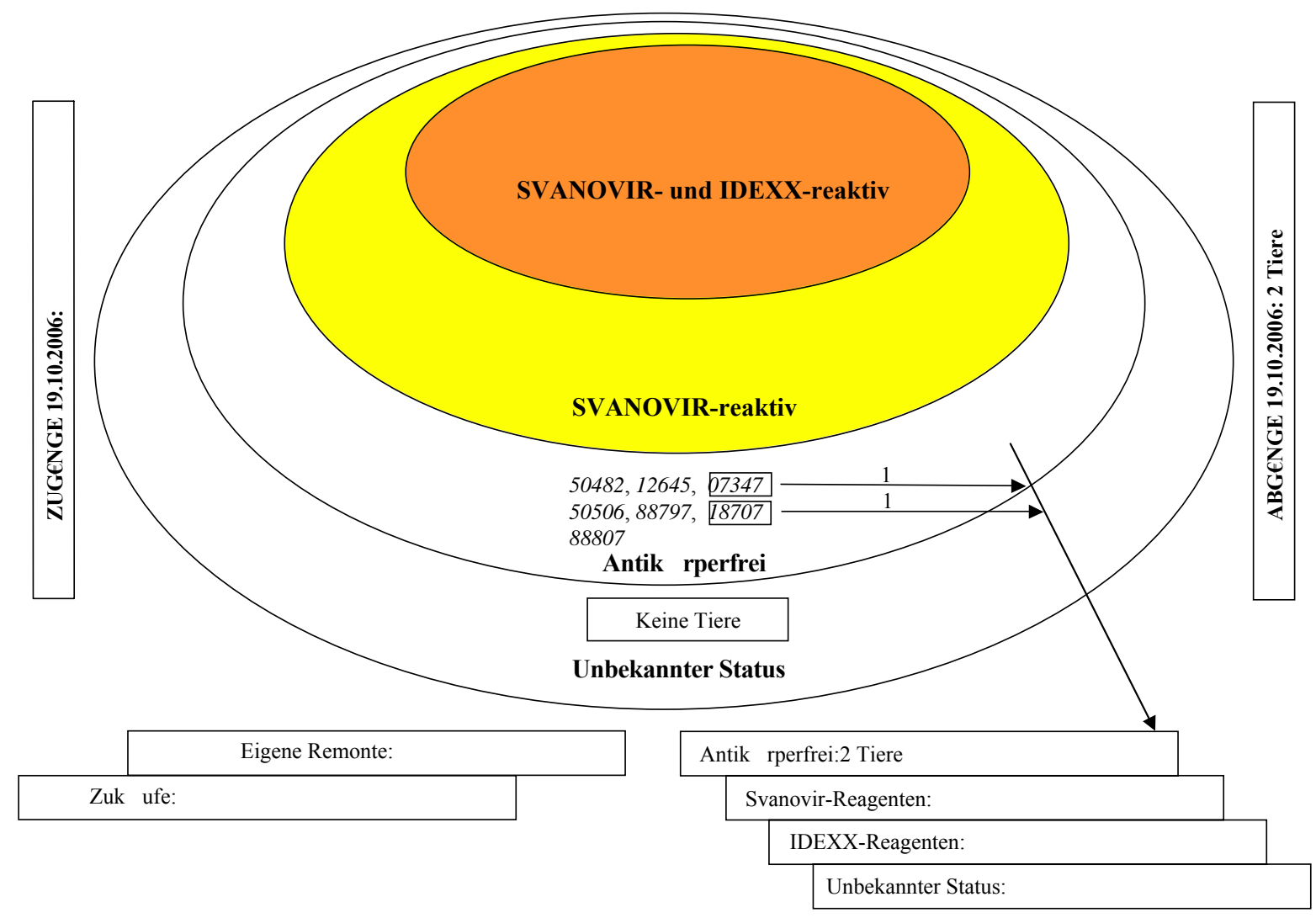

Abb. 30: Serologischer Status und Verbleib der in der PCR ermittelten Ausscheidertiere zum Untersuchungszeitpunkt 19.10.2006 

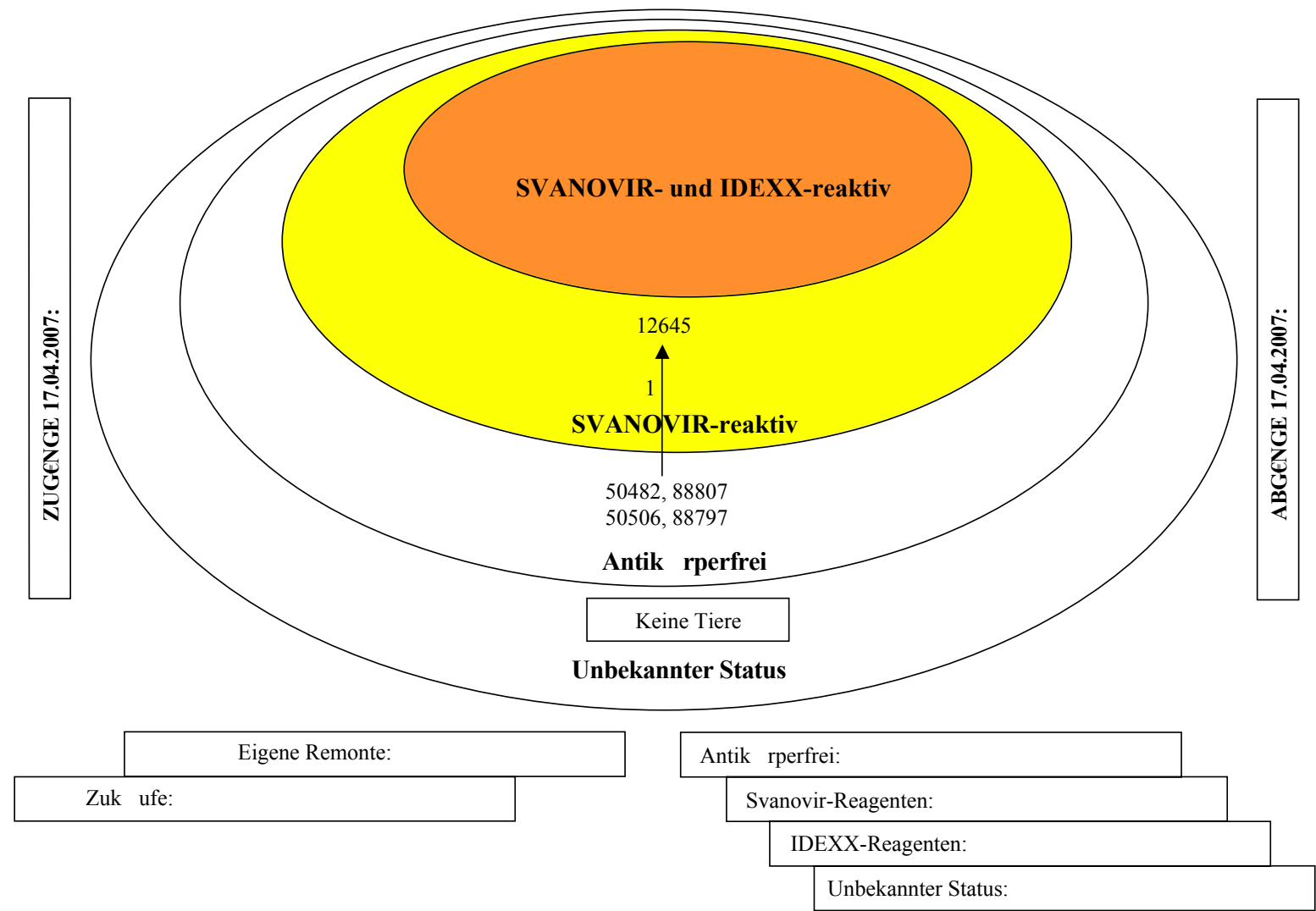

Abb. 31: Serologischer Status und Verbleib der in der PCR ermittelten Ausscheidertiere zum Untersuchungszeitpunkt 17.04.2007 


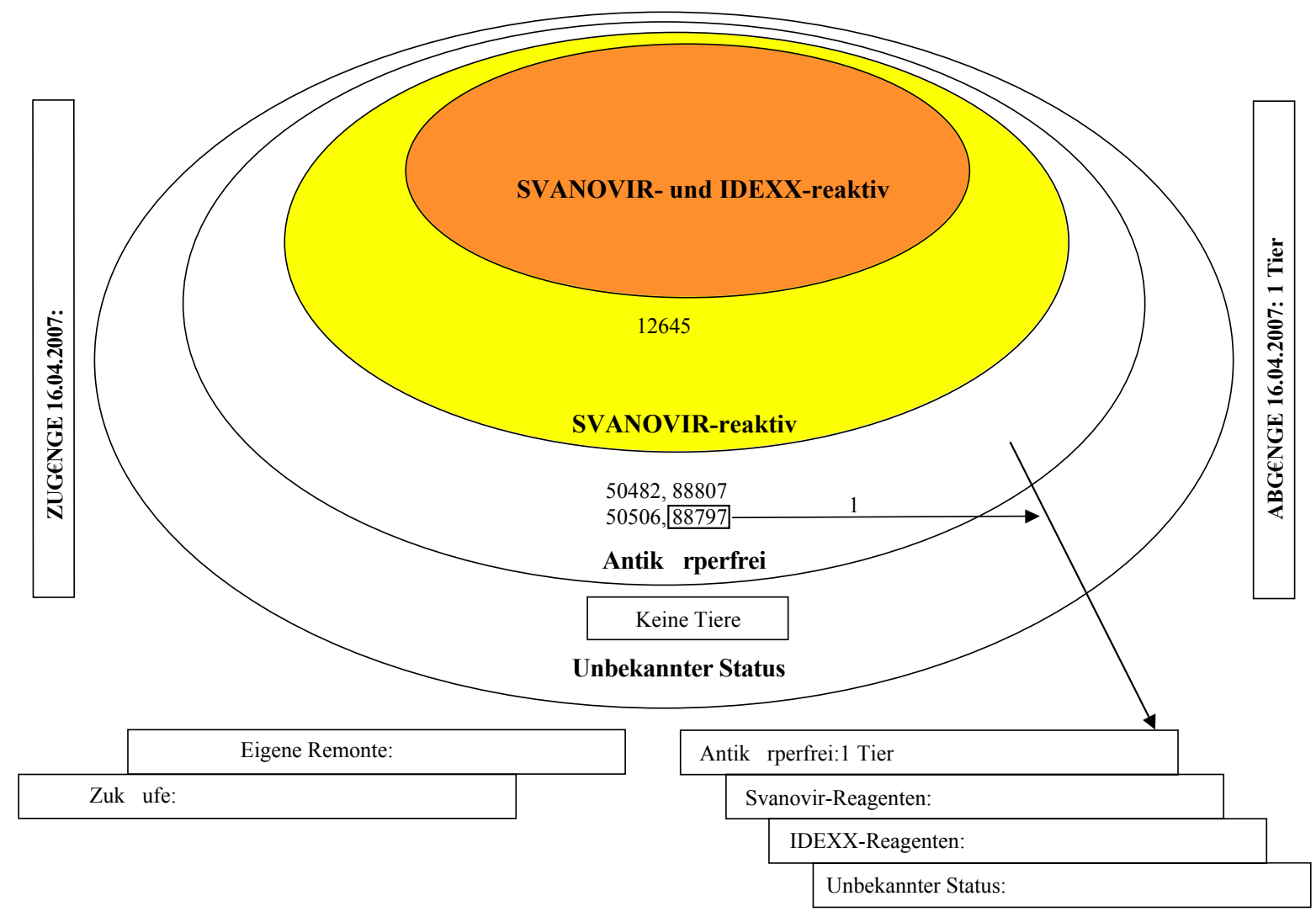

Abb.32: Serologischer Status und Verbleib der in der PCR ermittelten Ausscheidertiere zum Untersuchungszeitpunkt 22.10.2007 


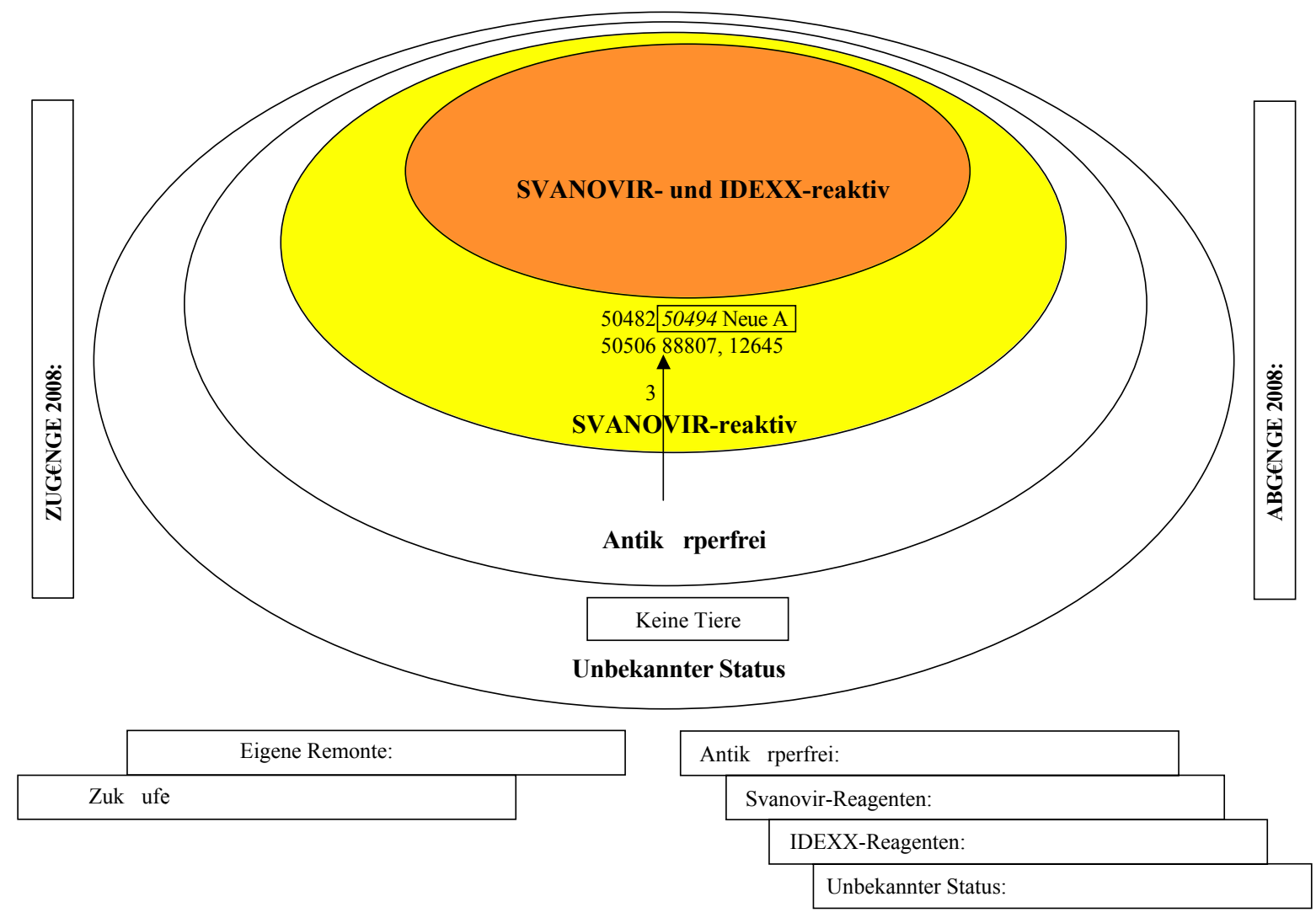

Abb. 33: Serologischer Status und Verbleib der in der PCR ermittelten Ausscheidertiere zum Untersuchungszeitpunkt 09.05.2008

4.2

Vergleich und Eignung der beiden eingesetzten ELISA-Testsysteme für die Paratuberkulosediagnostik

Die Zusammenstellung der serologischen Untersuchungen ergab, dass von den 270 SvanovirReagenten nach einer gewissen Zeit 118 (43,7\%) Tiere auch im IDEXX-ELISA reagiert haten. Einige Svanovir-ELISA-Reagenten wurden aus technischen und wirtschaftlichen Gründen aus der Herde entfernt, bevor bei diesen Tieren Antikörper mittels IDEXX-ELISA festgestellt werden konnten. Die Ergebnisse dieser Untersuchung zeigen, dass die betroffenen Tiere erst im Svanovir-ELISA reagieren, später im IDEXX-ELISA. 

chungszeitpunkten

Um die Korrelation zwischen dem Svanovir- und dem IDEXX-ELISA zu bestimmen, wurden die Ergebnisse der serologischen Untersuchungen (optische Dichte und Messwerte) sowohl im Svanovir- als auch im IDEXX-ELISA für die entsprechenden Tiere in eine Excel-Tabelle eingetragen. Dann wurden die Werte der optischen Dichte beider ELISAs mit Hilfe des Microsoft Excel Programms über die „Korrel“ Funktion miteinander korreliert. Für die optische Dichte betrug die Korrelation der beiden Tests 0,50. In entsprechender Weise wurden auch die prozentualen Werte des Svanovir-und IDEXX-ELISAs miteinander korreliert. Hierbei betrug die Korrelation der beiden Tests 0,59 (Abb. 34-35).

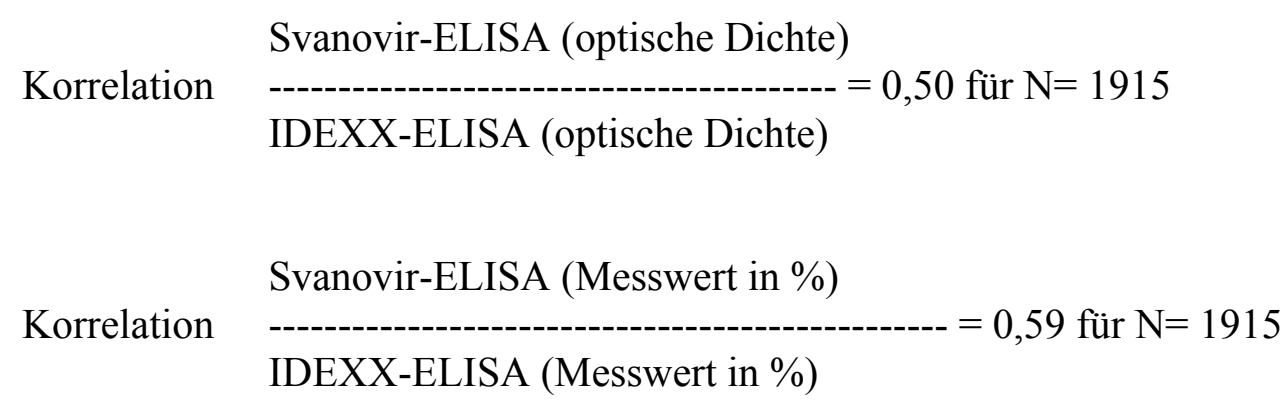




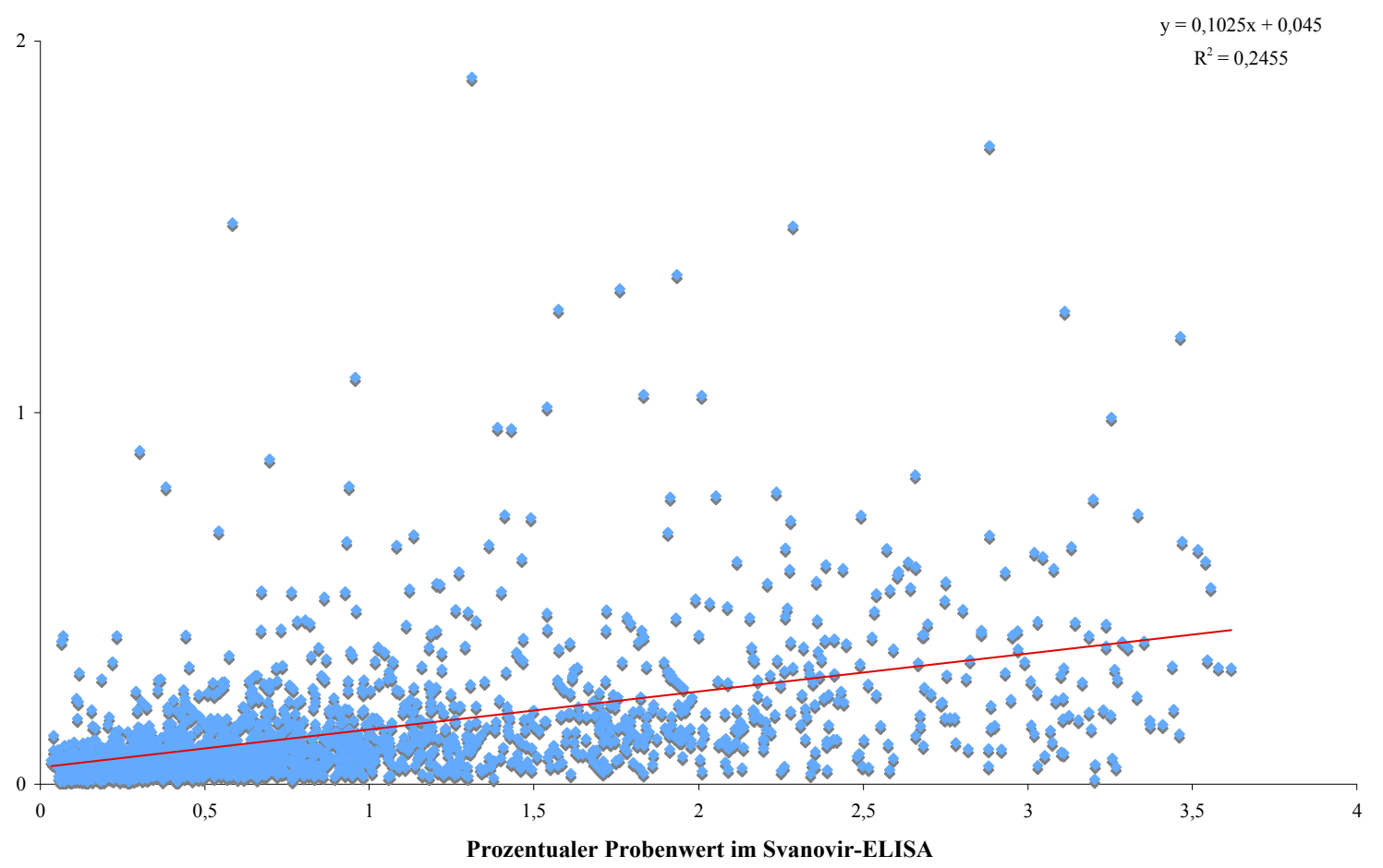

Abb. 34: Korrelation der prozentualen Probenwerte vom Svanovir-ELISA mit dem IDEXXELISA $(\mathrm{N}=1915)$

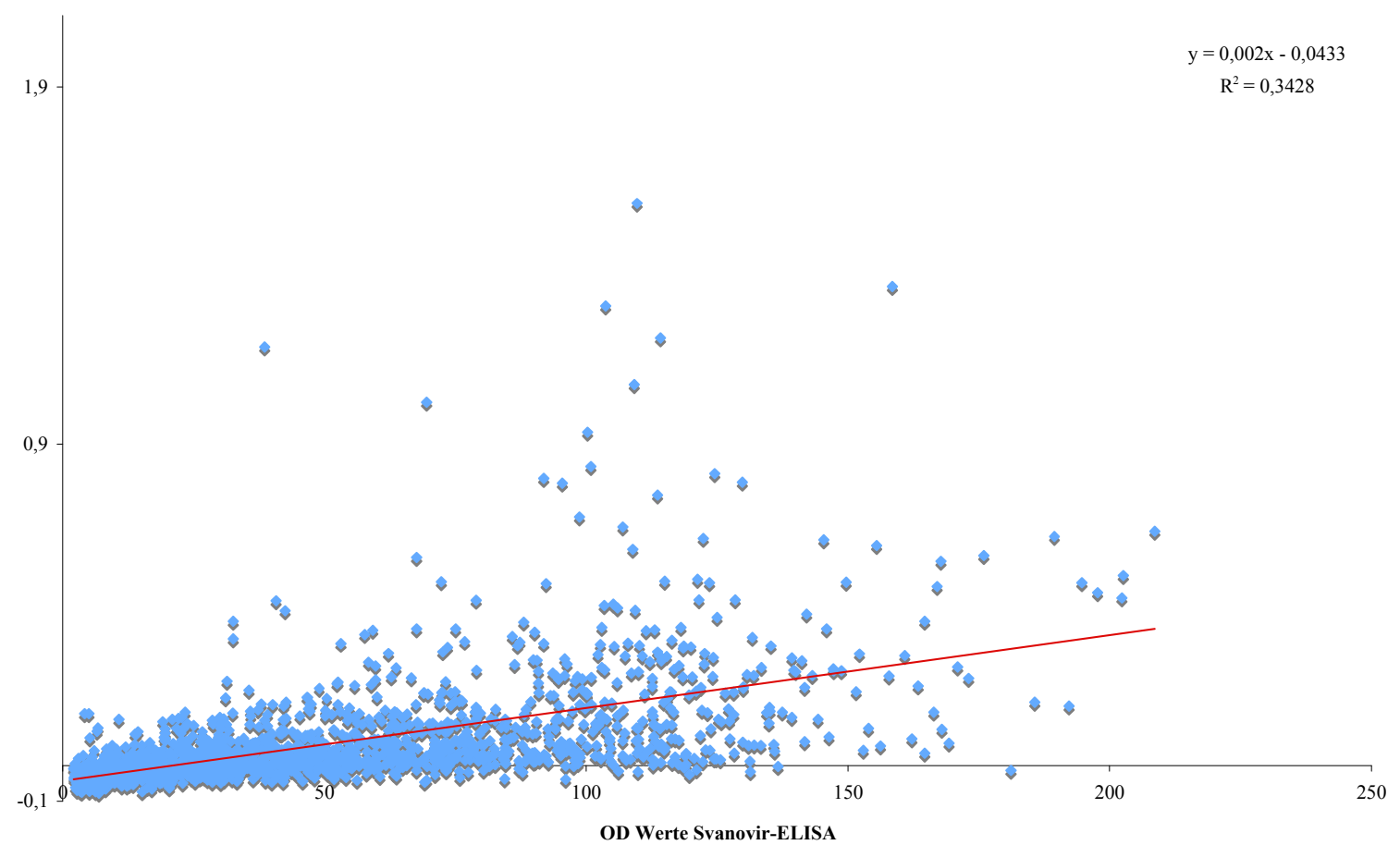

Abb. 35: Korrelation der optischen Dichte vom Svanovir-ELISA mit dem IDEXX-ELISA $(\mathrm{N}=1915)$ 

Svanovir- und im IDEXX-ELISA

In der gesamten Untersuchungsperiode vom 08.02.2000 bis 09.05.2008 waren 382 Tiere in regelmässigen Abständen mehrmals serologisch untersucht worden. Um die Antikörperbildung bei den Tieren in den verschiedenen Altersgruppen feststellen zu können, wurden die Ergebnisse der serologischen Untersuchungen zusammengestellt und ausgewertet.

Im gesamten Untersuchungszeitraum waren im Svanovir-ELISA insgesamt 270 Tiere als Reagenten erkannt worden. Von diesen 270 Svanovir-ELISA-Reagenten sind in diesem Untersuchungszeitraum 118 Tiere zu IDEXX-Reagenten geworden. Die serologischen Ergebnisse wurden nach dem Alter der Tiere ausgewertet. Die Auswertungen zeigten, dass im Svanovir-ELISA 107 Reagenten im Alter zwischen 2-3 Jahren, 100 Reagenten 3-4 Jahre, 38 Reagenten 4-5 Jahre, 14 Reagenten 5-6 Jahre, 6 Reagenten zwischen 6-7 Jahre, 3 Reagenten zwischen 7-8 Jahren, 1 Reagent zwischen 8-9 Jahre sowie 1 Reagent 9-10 Jahre alt waren. Von den 118 IDEXX-Reagenten waren 16 Reagenten 2-3 Jahre alt, 48 Reagenten zwischen 34 Jahre, 31 Reagenten zwischen 4-5 Jahre, 17 Reagenten zwischen 5-6 Jahre, 3 Reagenten zwischen 6-7 Jahre, 1 Reagent zwischen 7-8 Jahre, 1 Reagent zwischen 8-9 Jahre und 1 Reagent war 9-10 Jahre alt (Abb. 36-37).

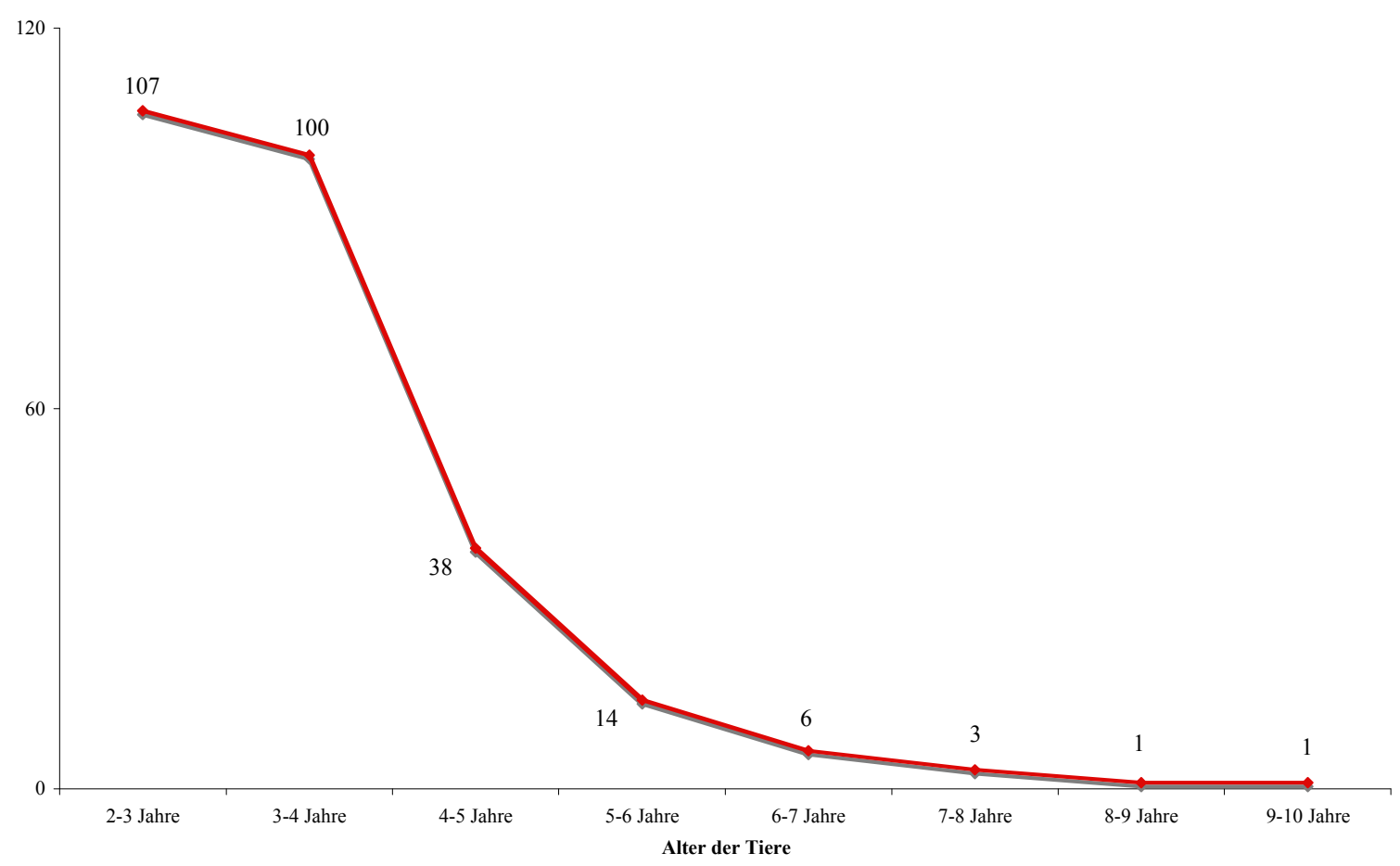

Abb. 36: Svanovir-Reagenten: Ermittlung der Tierzahl pro Altersgruppe, in der erstmals Antikörper nachgewiesen werden konnten 


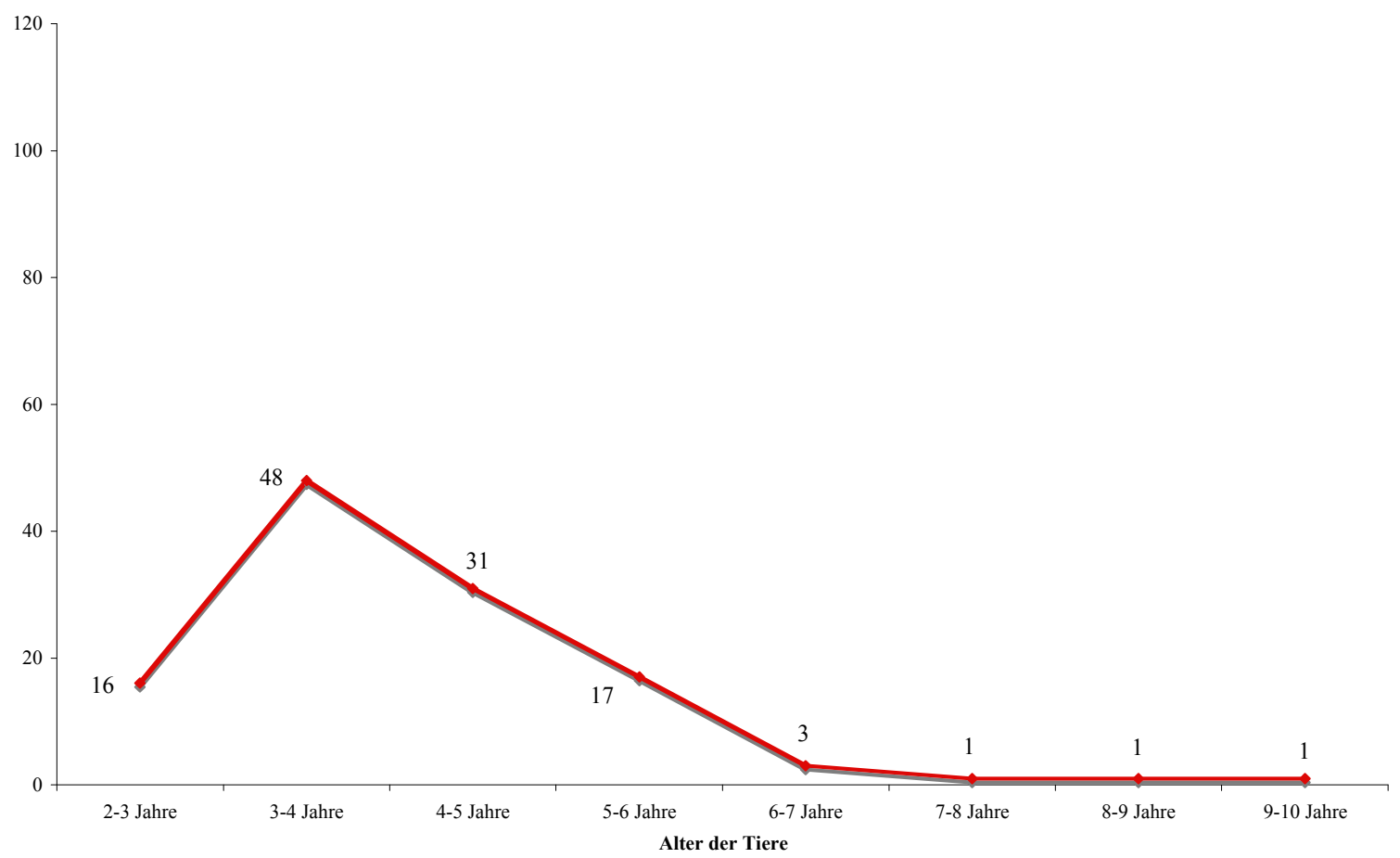

Abb. 37: IDEXX-Reagenten: Ermittlung der Tierzahl pro Altersgruppe, in der erstmals Antikörper nachgewiesen werden konnten

\subsection{3} Grafische Darstellung serologischer Ergebnisse bei ausgewählten Tieren

Am 27.07.2005 waren außergewöhnlich viele Tiere im IDEXX-ELISA Reagenten. Um herauszufinden, ob die Tiere auf einmal spontan im IDEXX-ELISA reagiert hatten, oder in den vergangenen Untersuchungen bereits im Svanovir-ELISA-Reagenten gewesen waren, wurden die serologischen Ergebnisse in beiden Tests rückverfolgt. Dabei stellte sich heraus, dass, bevor die Tiere im IDEXX-ELISA reagierten, sie auch bereits im Svanovir-ELISA Reagenten gewesen waren. Um die Antikörperbildung bei den Tieren anschaulich zu machen, wurden die Ergebnisse in eine Excel-Tabelle eingetragen und dann grafisch dargestellt (Abb. 38-50). 
Svanovir-ELISA

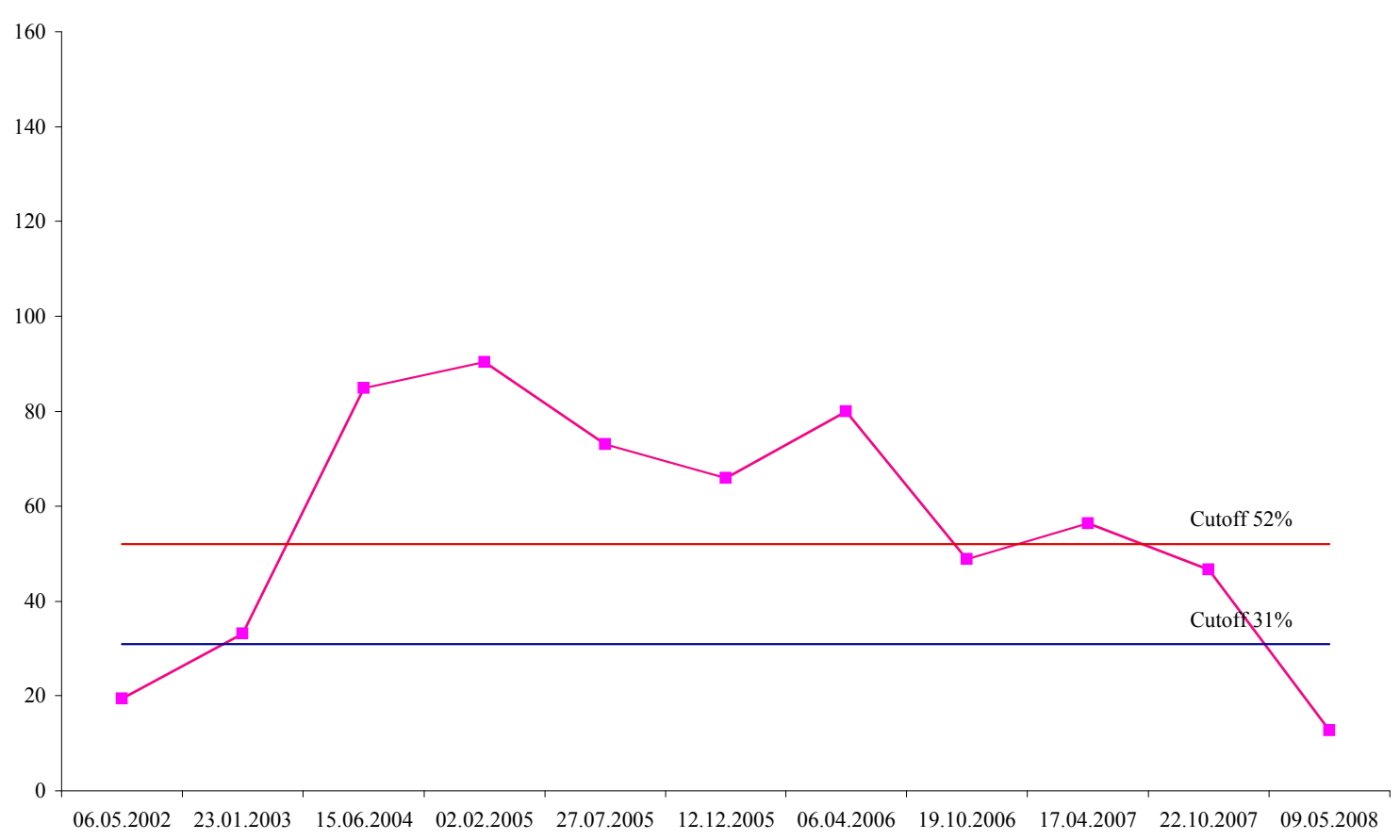

Ohrmarke Nr. 07318

IDEXX-ELISA

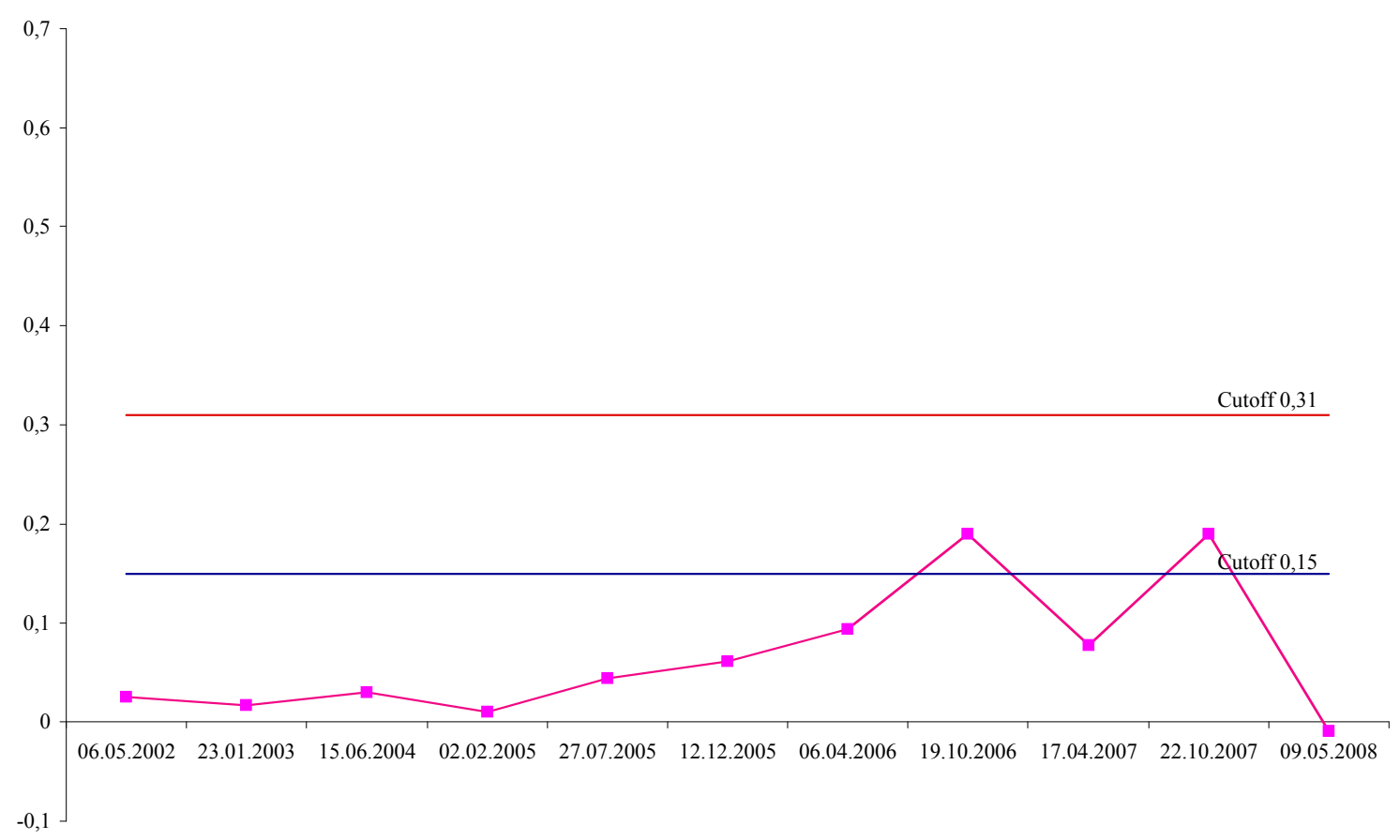

Ohrmarke Nr. 07318

Abb. 38: Grafische Darstellung der Svanovir- und IDEXX-ELISA-Ergebnisse für Ohrmarkennummer 07318 


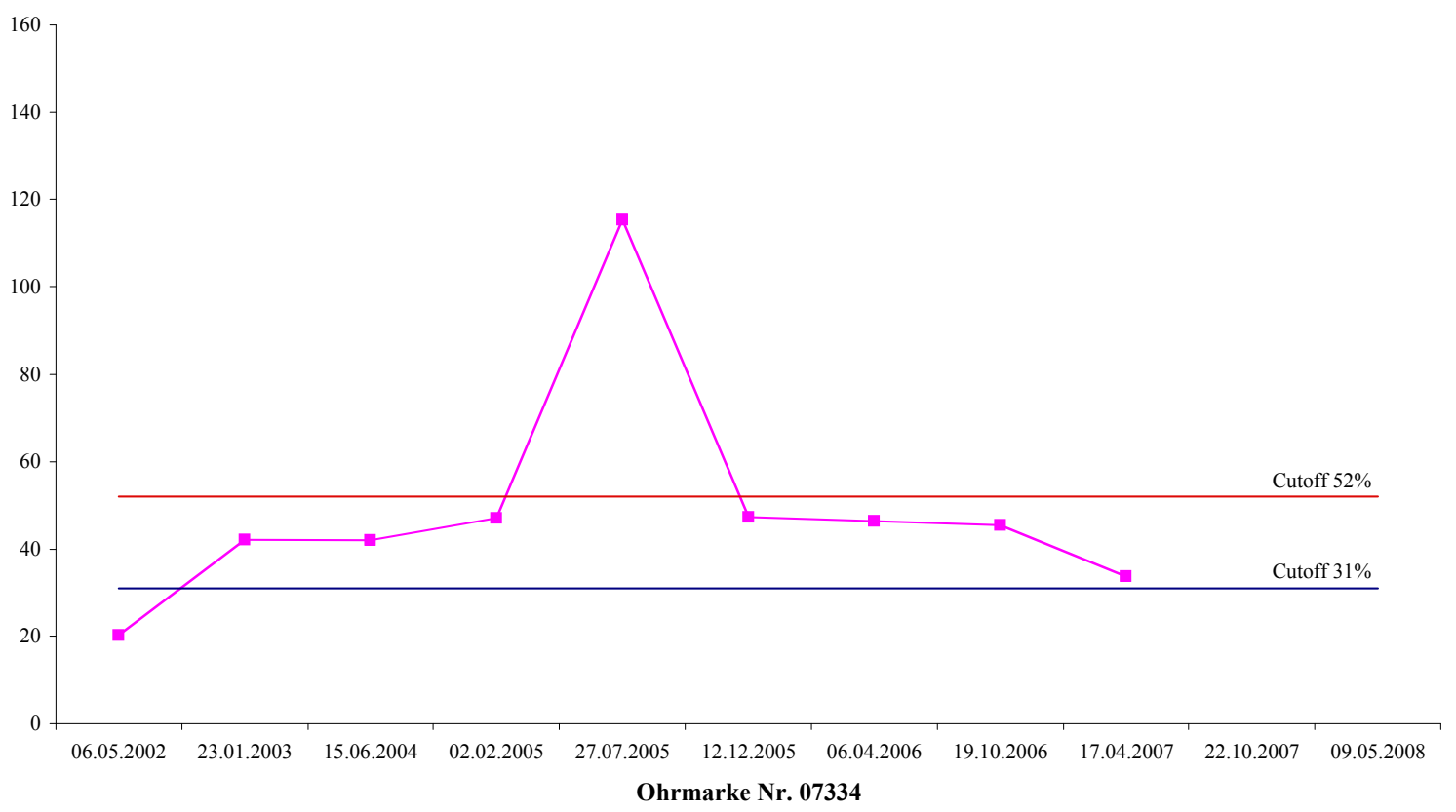

IDEXX-ELISA

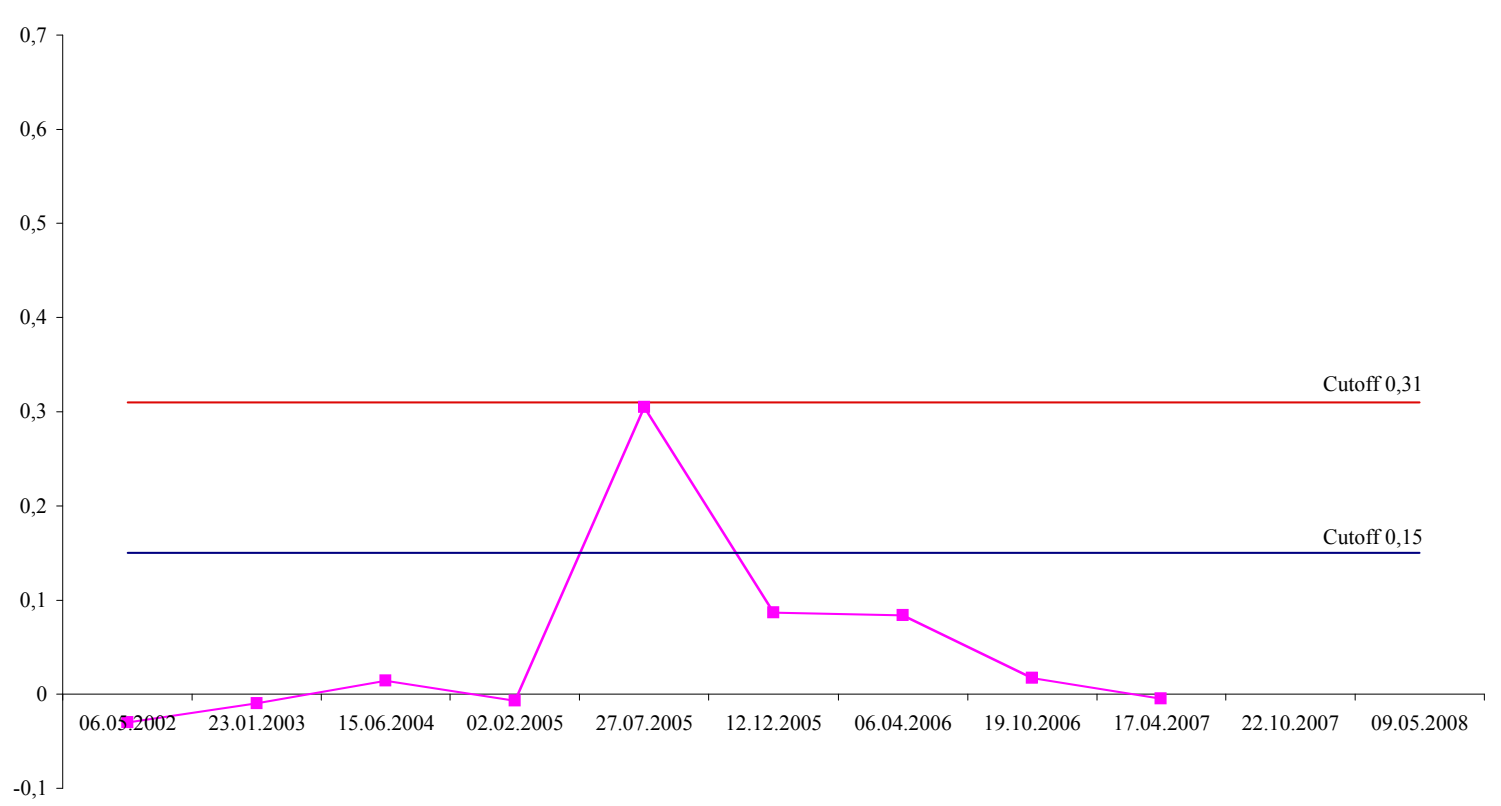

Ohrmarke Nr. 07334

Abb. 39: Grafische Darstellung der Svanovir- und IDEXX-ELISA-Ergebnisse für Ohrmarkennummer 07334 


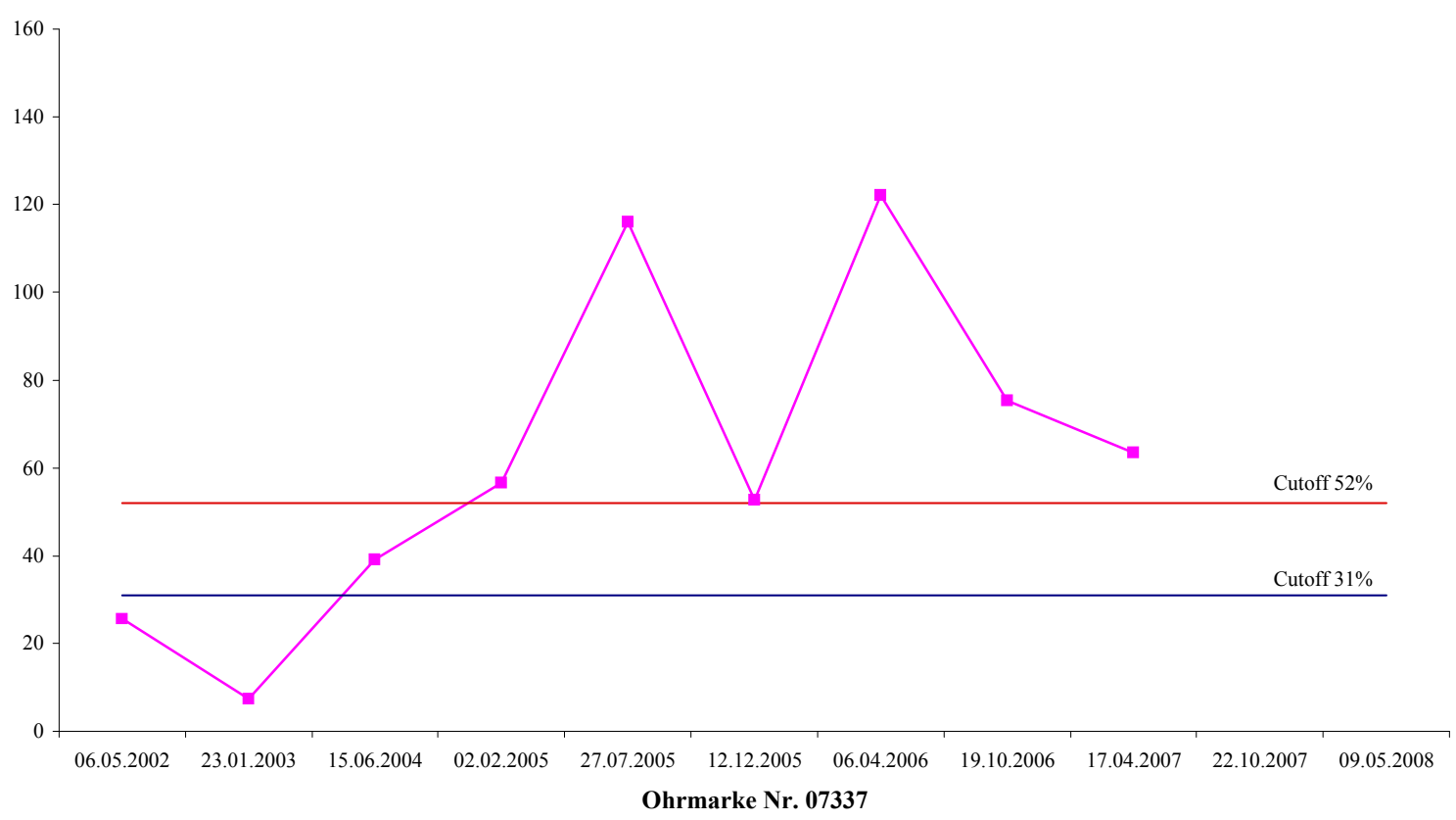

IDEXX-ELISA

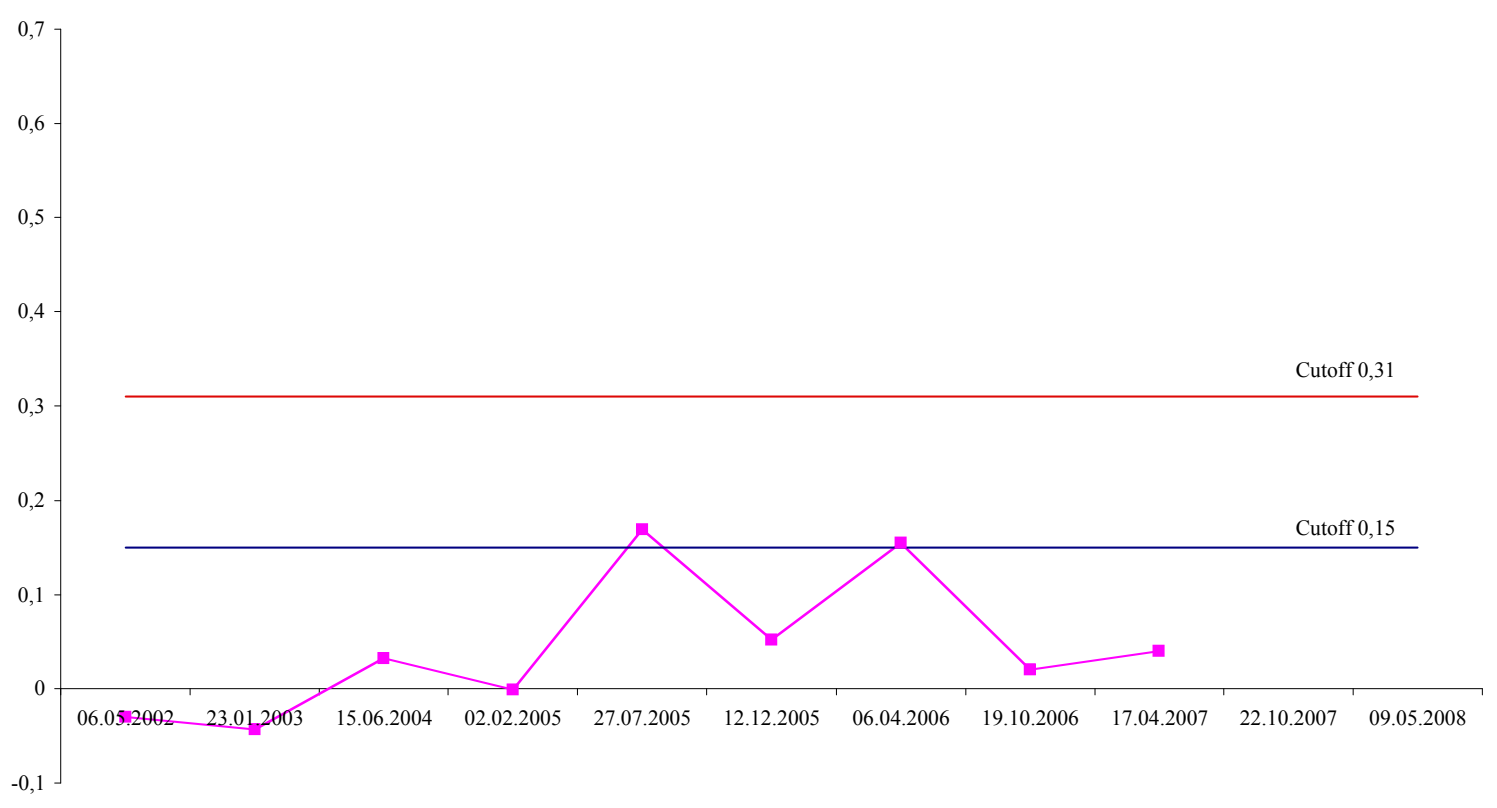

Ohrmarke Nr. 07337

Abb. 40: Grafische Darstellung der Svanovir- und IDEXX-ELISA-Ergebnisse für Ohrmarkennummer 07337 


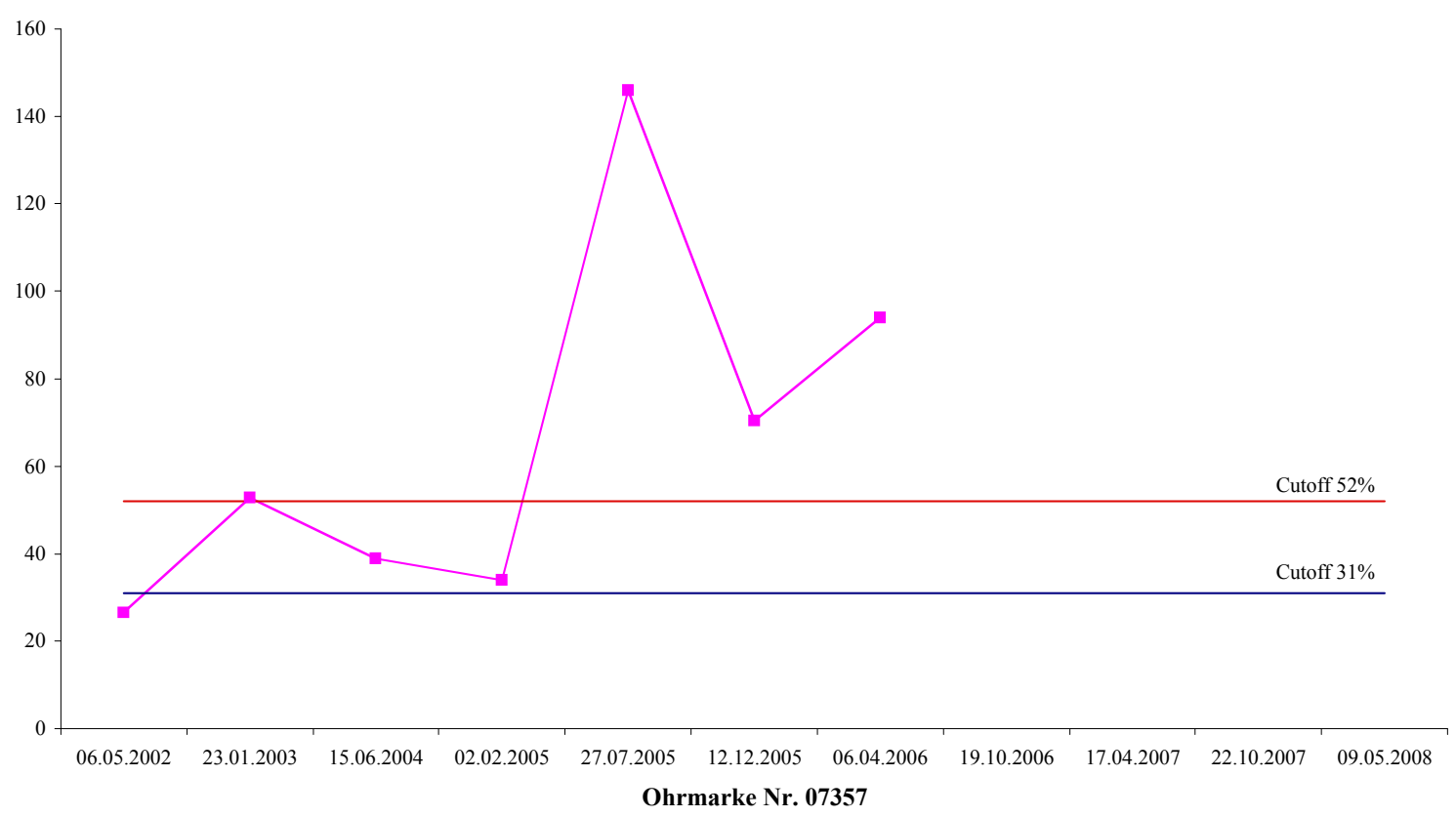

IDEXX-ELISA

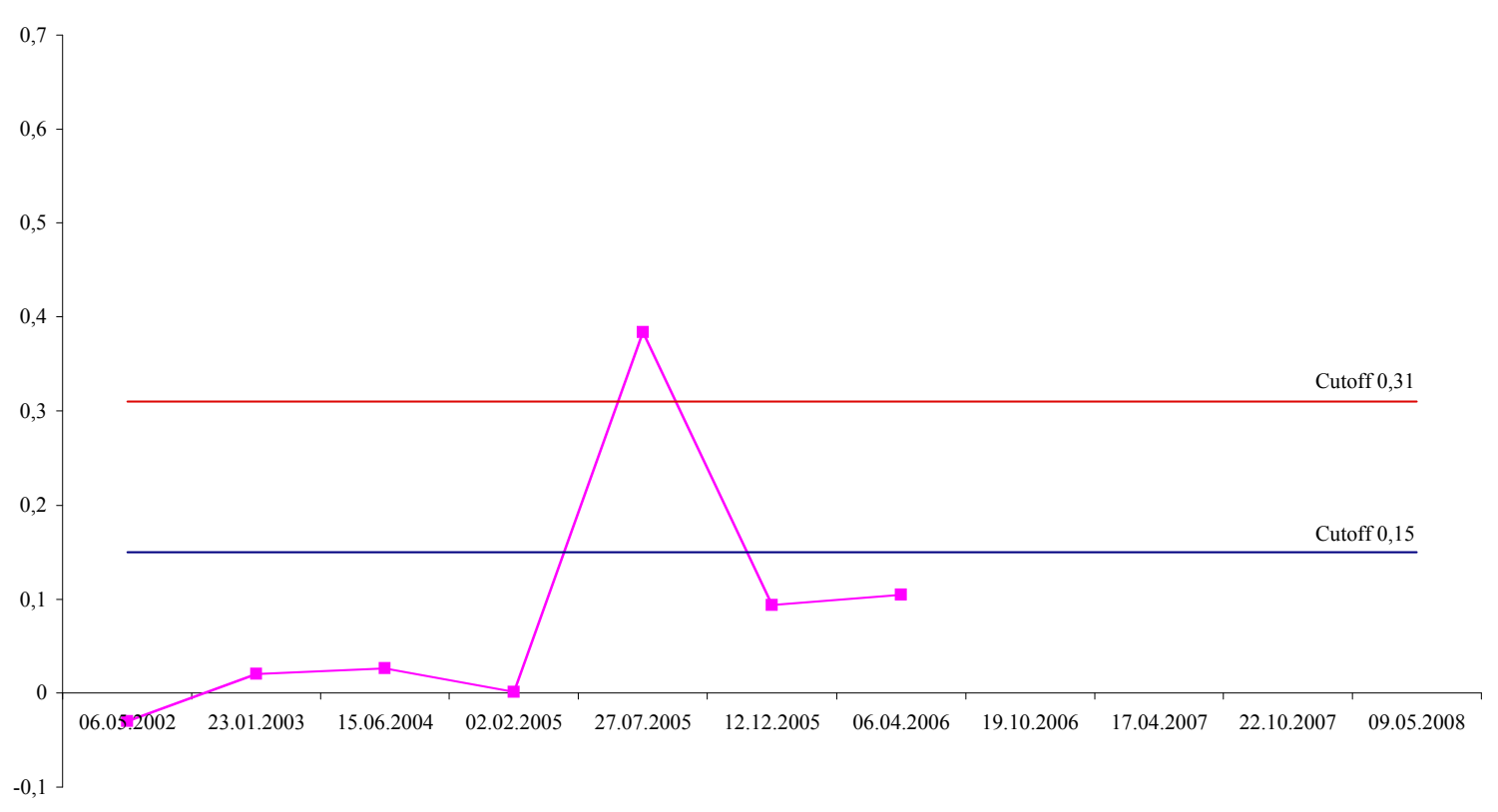

Ohrmarke Nr. 07357

Abb. 41: Grafische Darstellung der Svanovir- und IDEXX-ELISA-Ergebnisse für Ohrmarkennummer 07357 


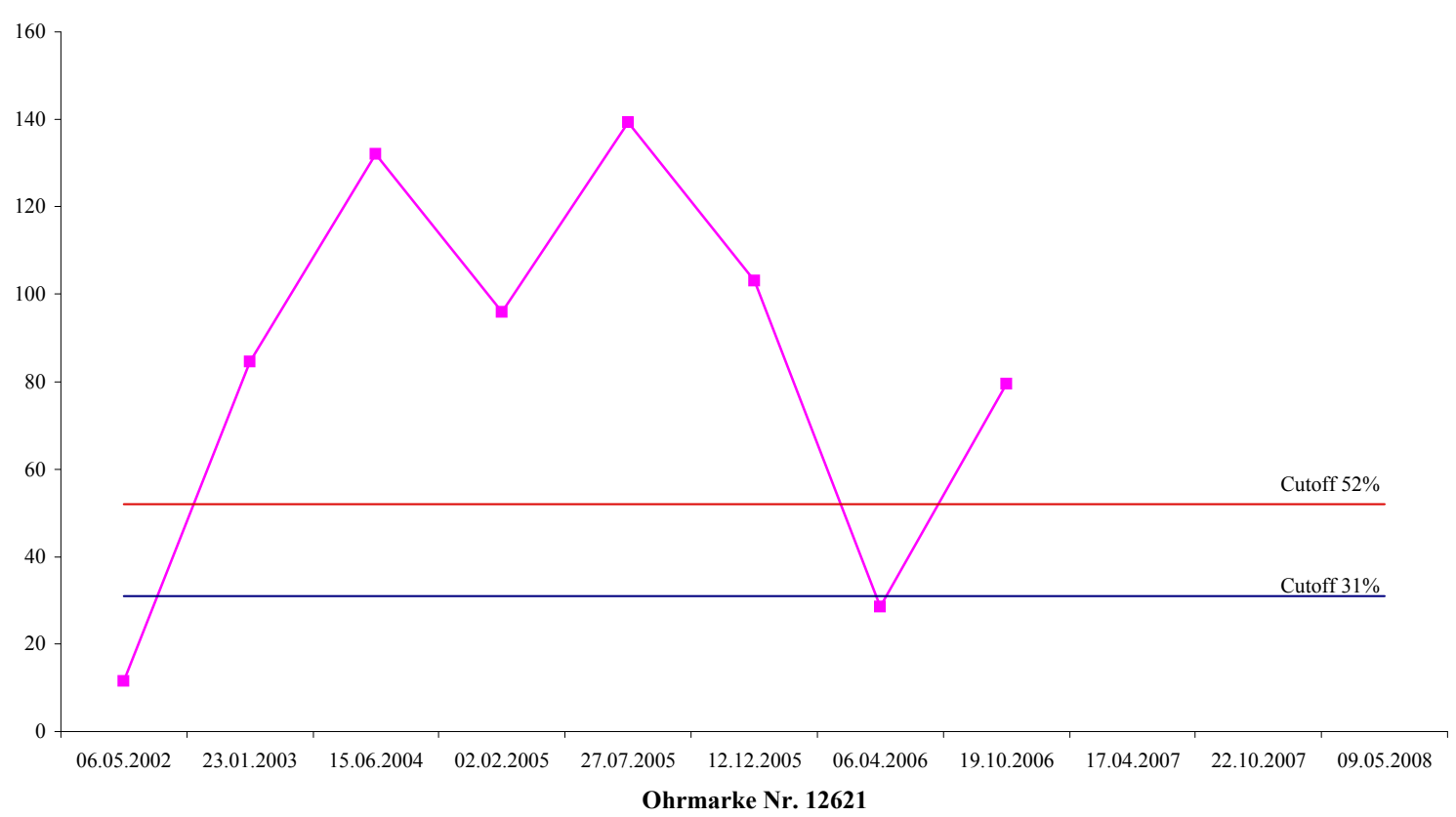

IDEXX-ELISA

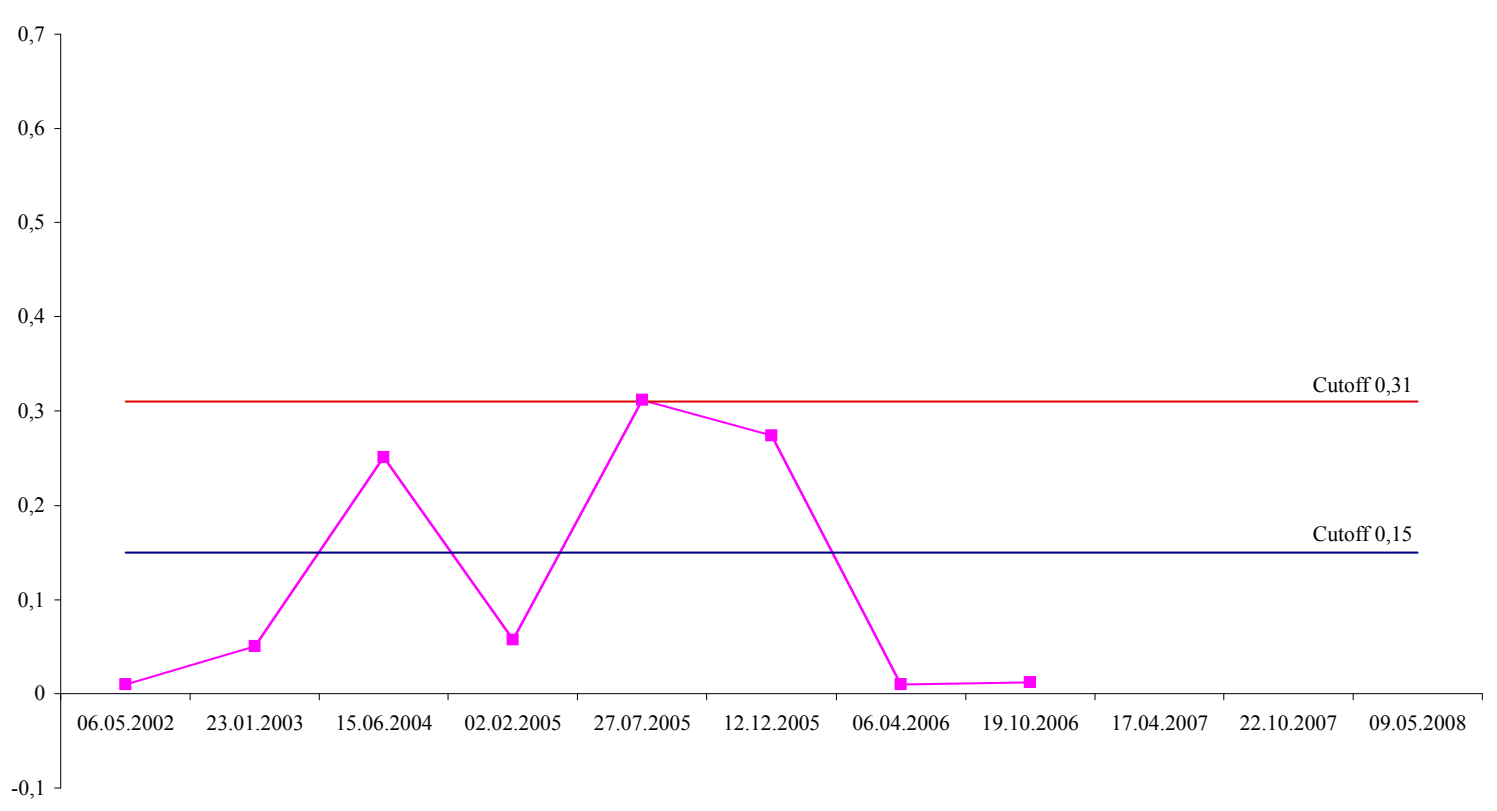

Ohrmarke Nr. 12621

Abb. 42: Grafische Darstellung der Svanovir- und IDEXX-ELISA-Ergebnisse für Ohrmarkennummer 12621 


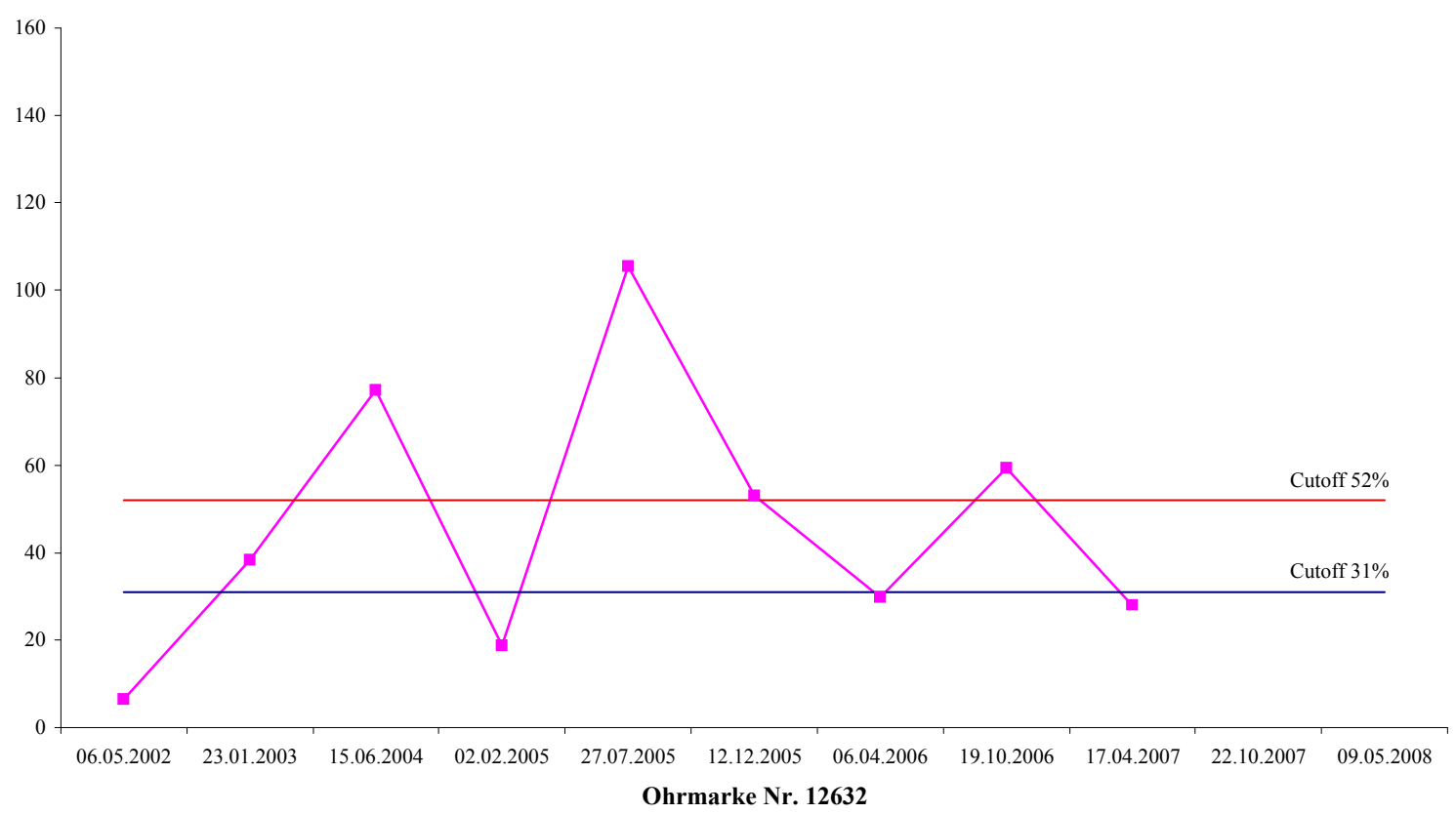

IDEXX-ELISA

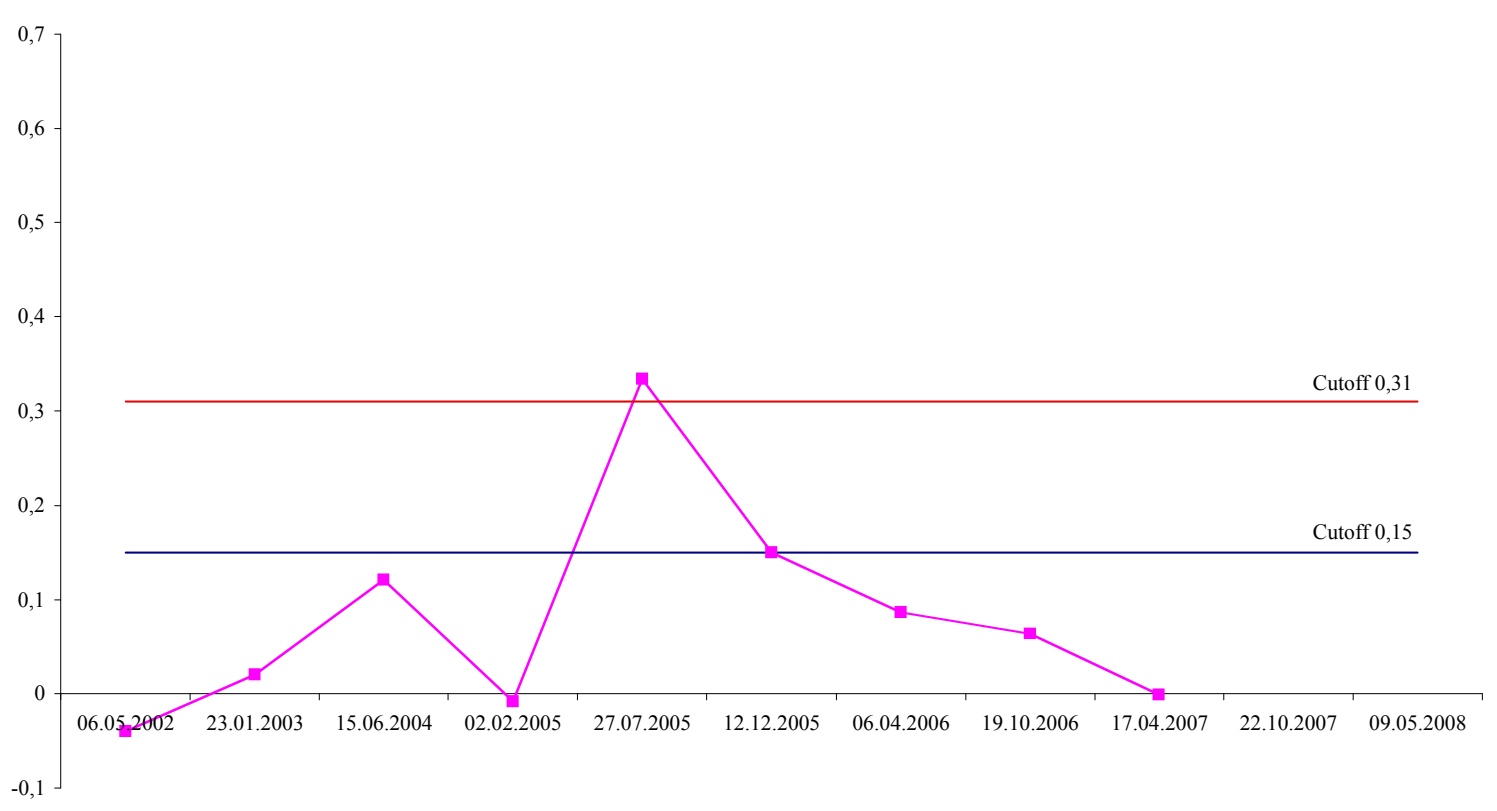

Ohrmarke Nr. 12632

Abb. 43: Grafische Darstellung der Svanovir- und IDEXX-ELISA-Ergebnisse für Ohrmarkennummer 12632 


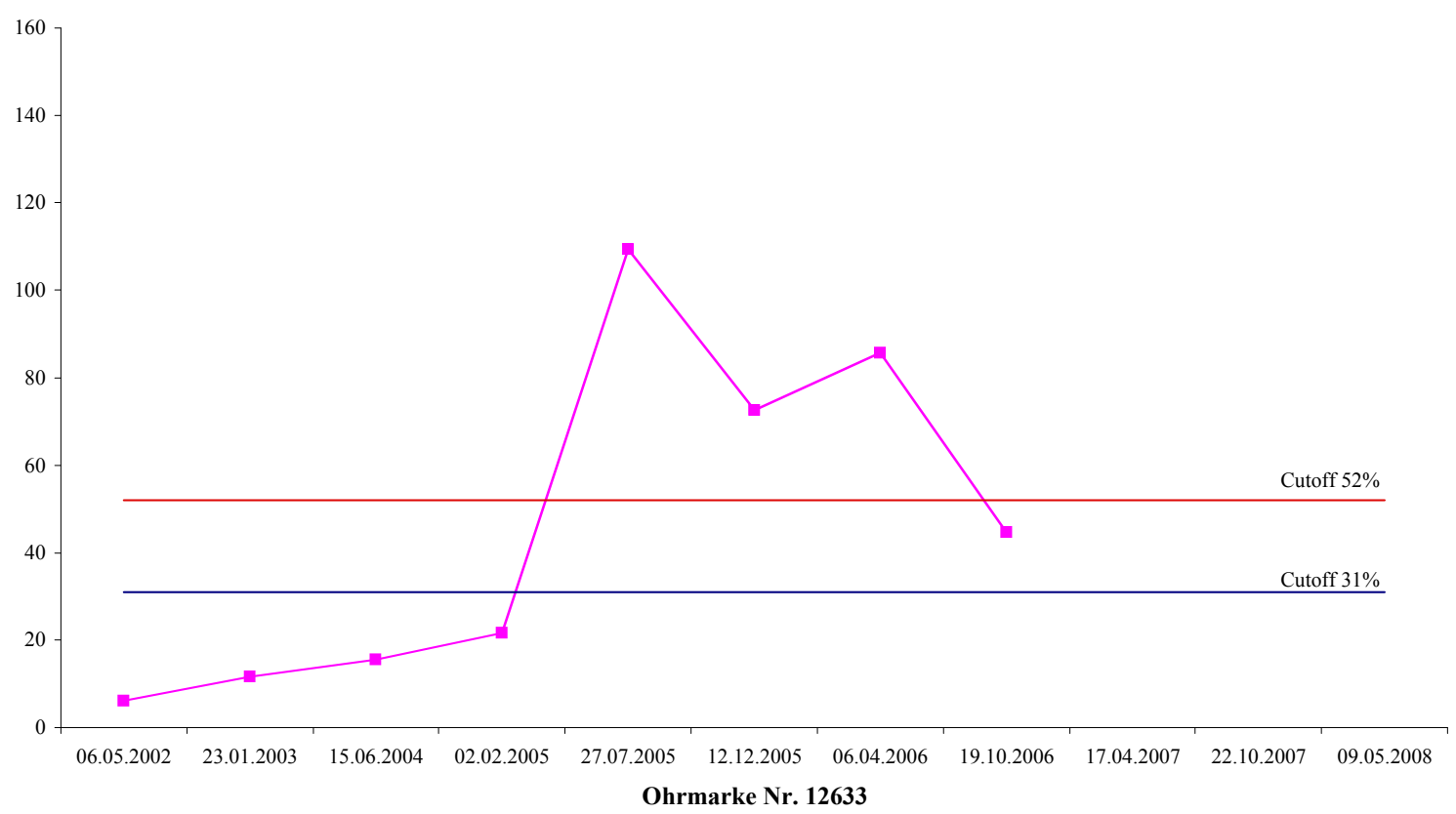

IDEXX-ELISA

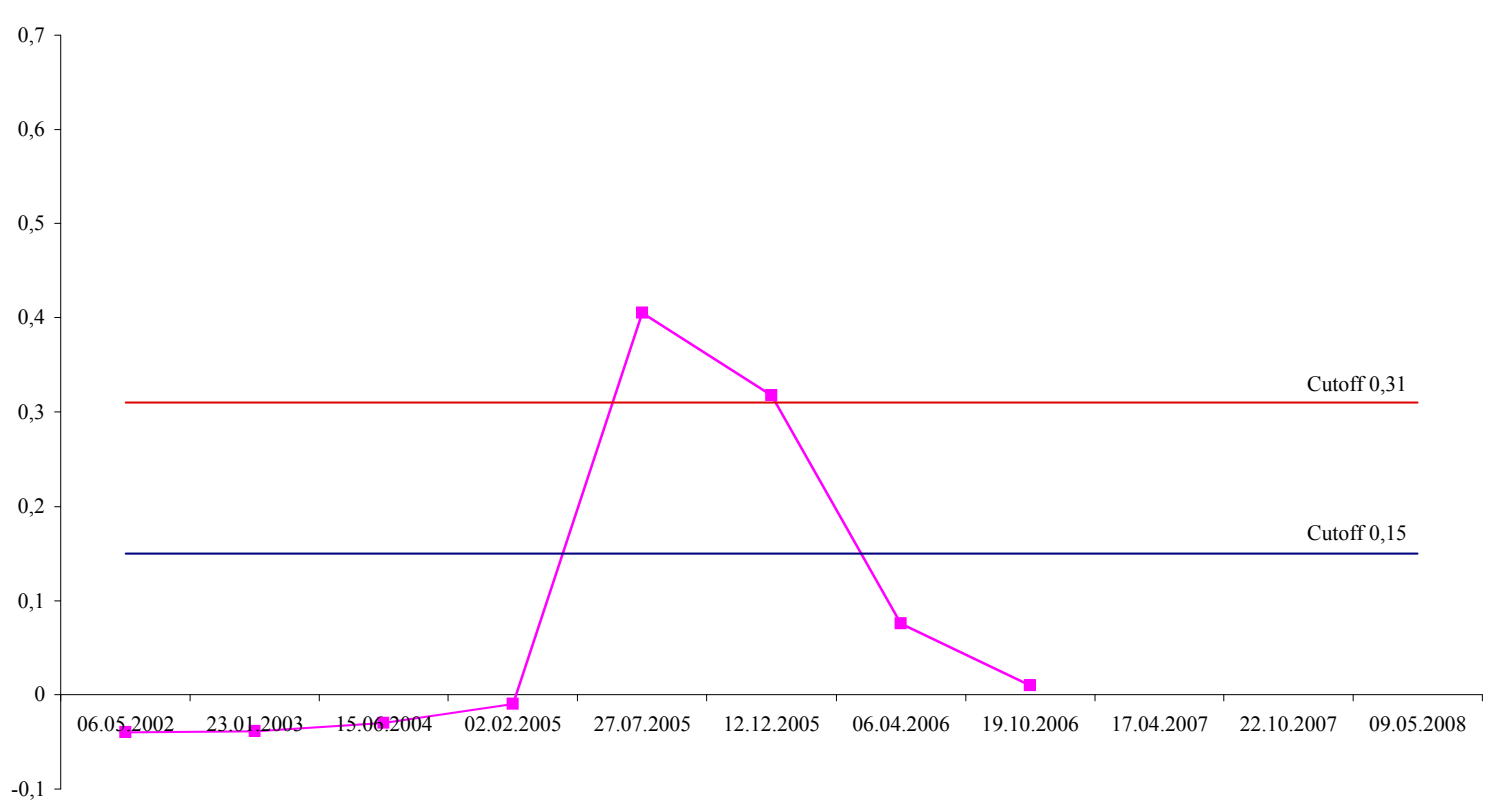

Ohrmarke Nr. 12633

Abb. 44: Grafische Darstellung der Svanovir- und IDEXX-ELISA-Ergebnisse für Ohrmarkennummer 12633 


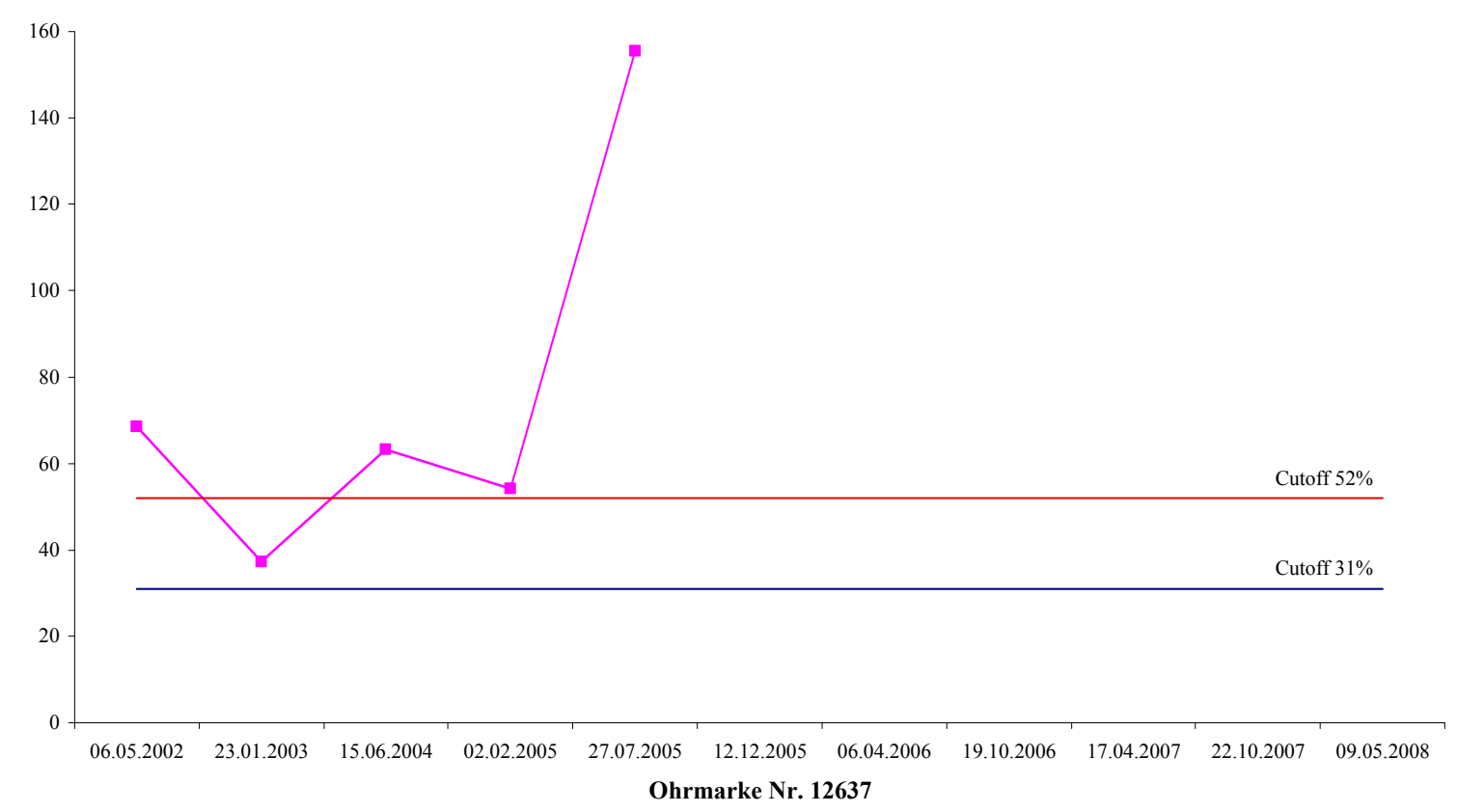

IDEXX-ELISA

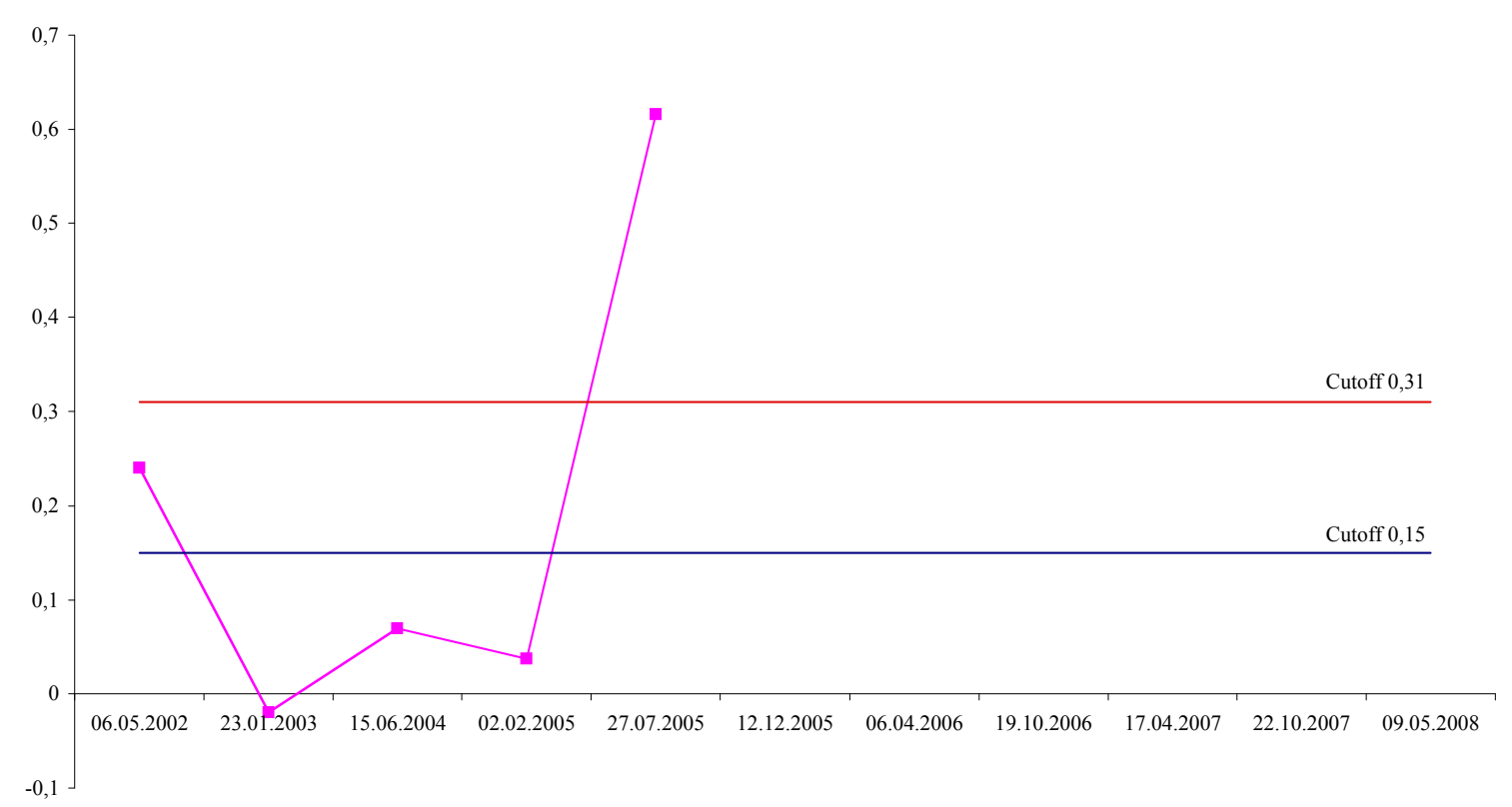

Ohrmarke Nr. 12637

Abb. 45: Grafische Darstellung der Svanovir- und IDEXX-ELISA-Ergebnisse für Ohrmarkennummer 12637 


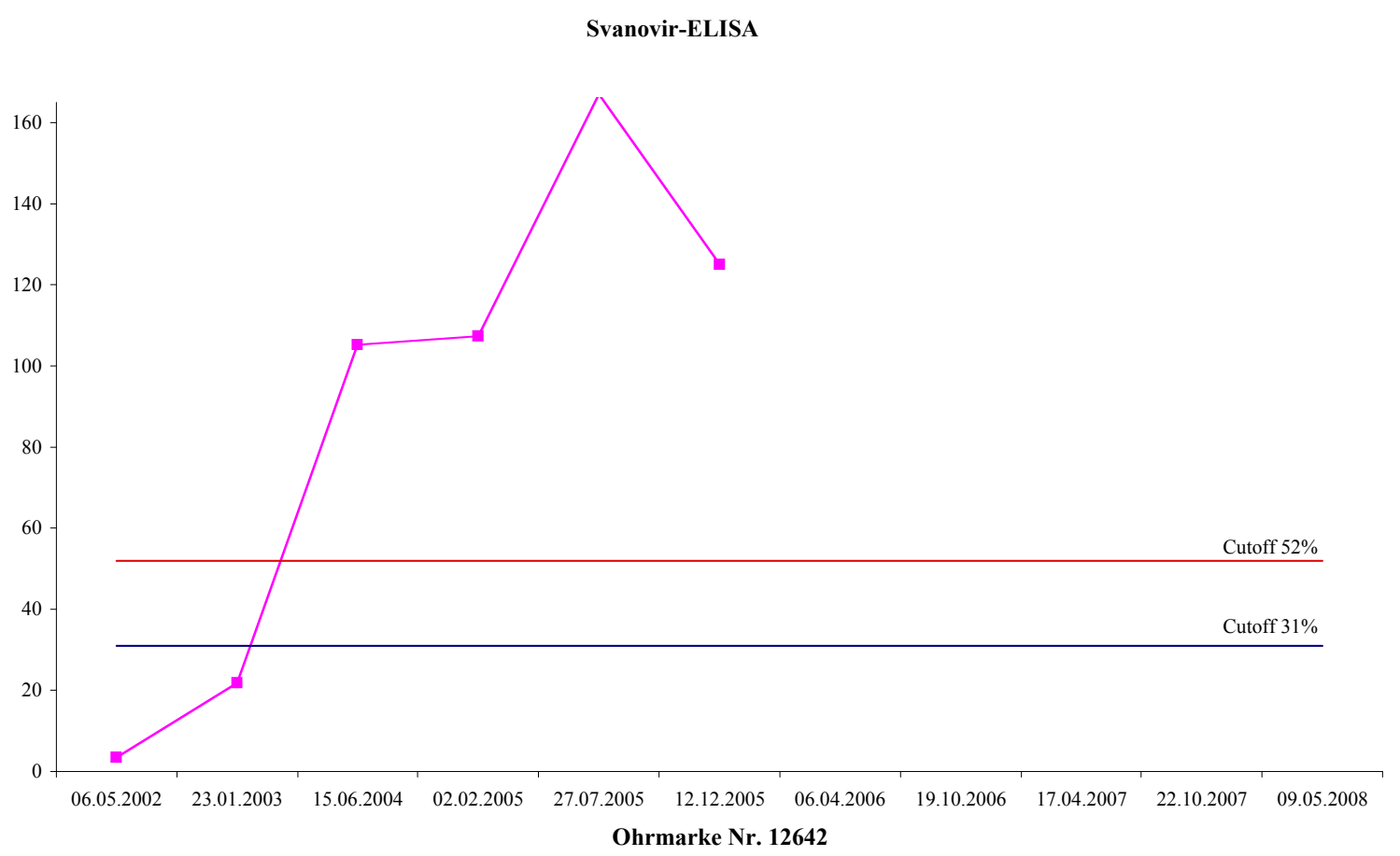

IDEXX-ELISA

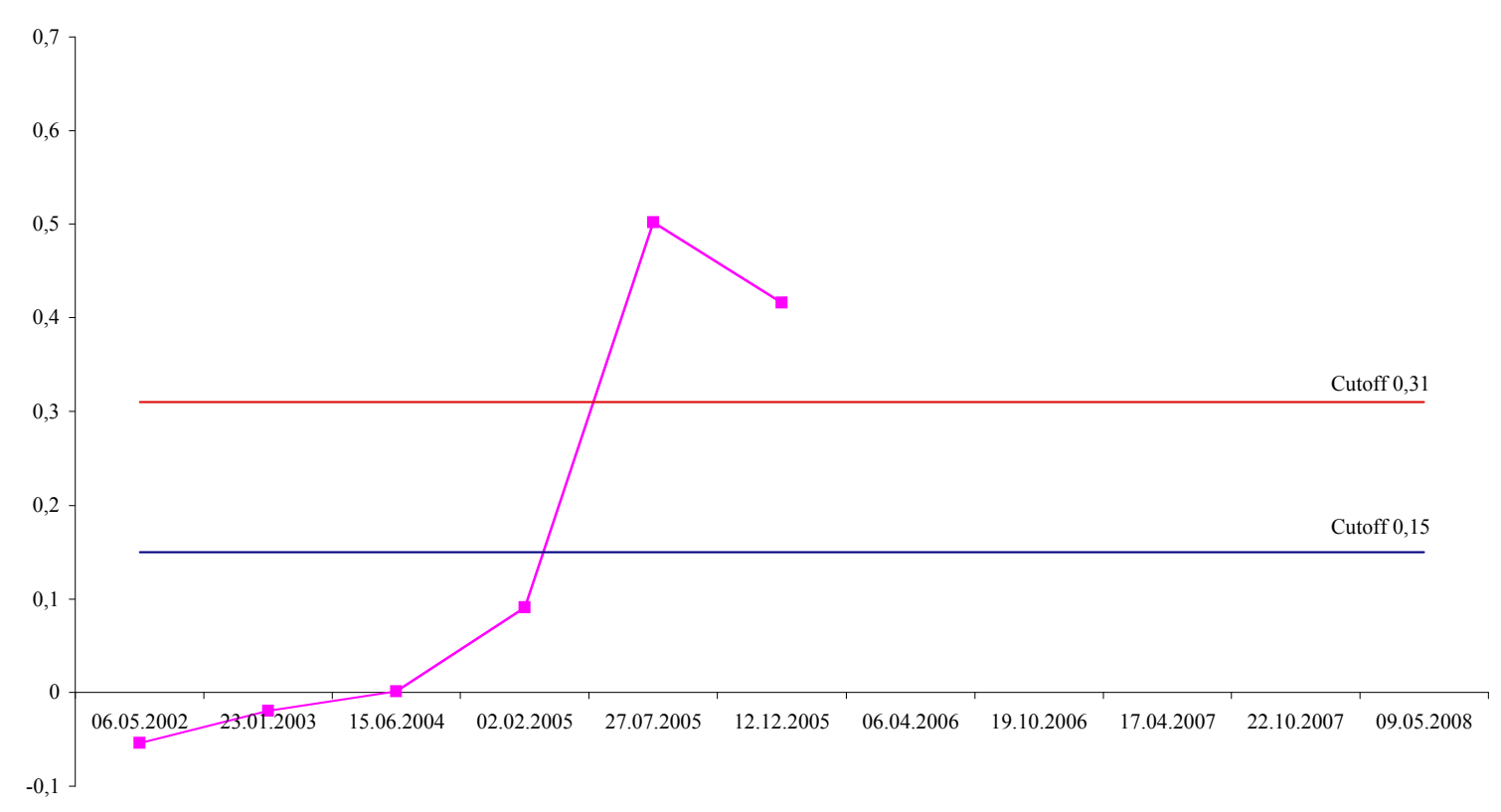

Ohrmarke Nr. 12642

Abb. 46: Grafische Darstellung der Svanovir- und IDEXX-ELISA-Ergebnisse für Ohrmarkennummer 12642 


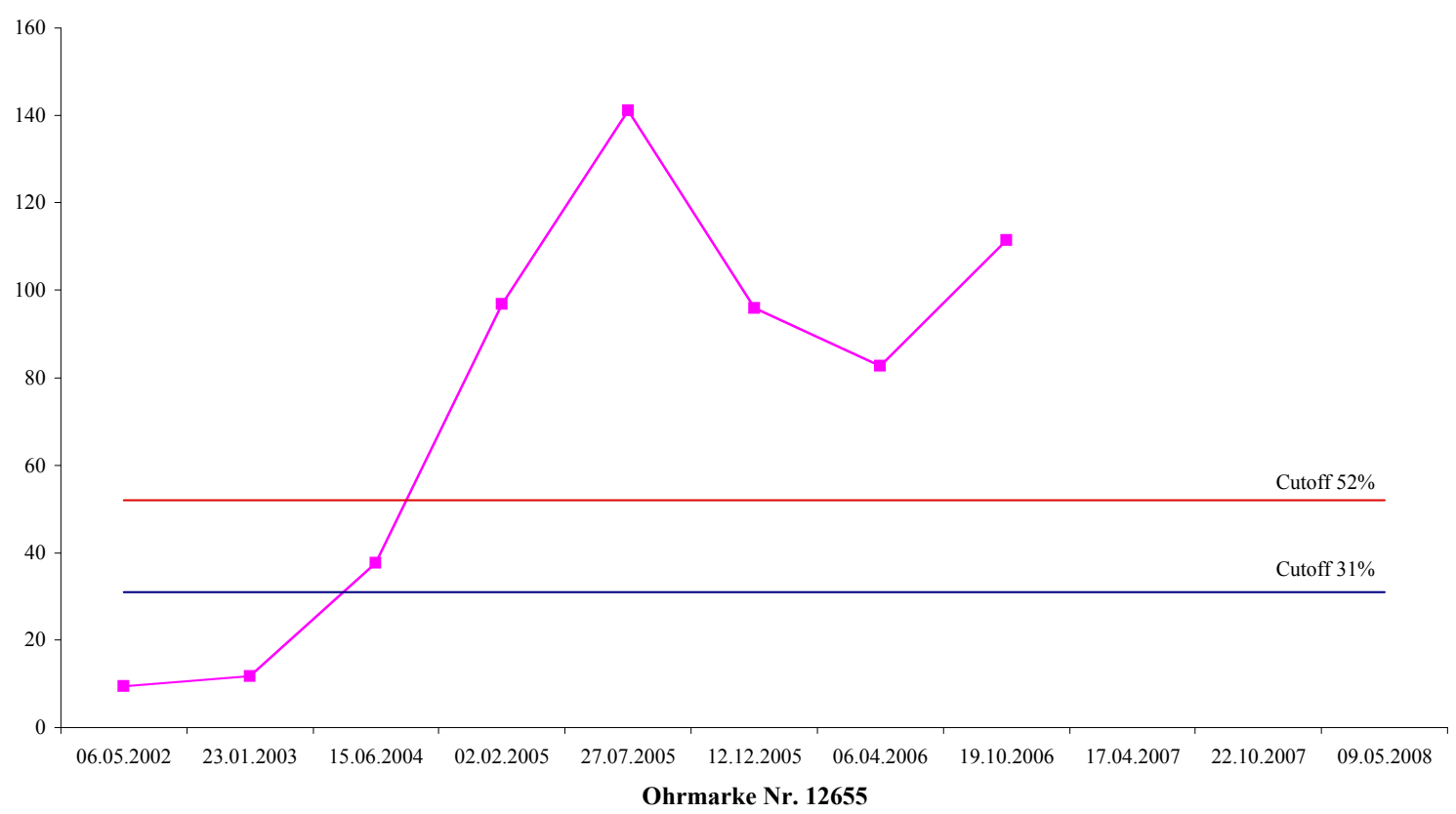

IDEXX-ELISA

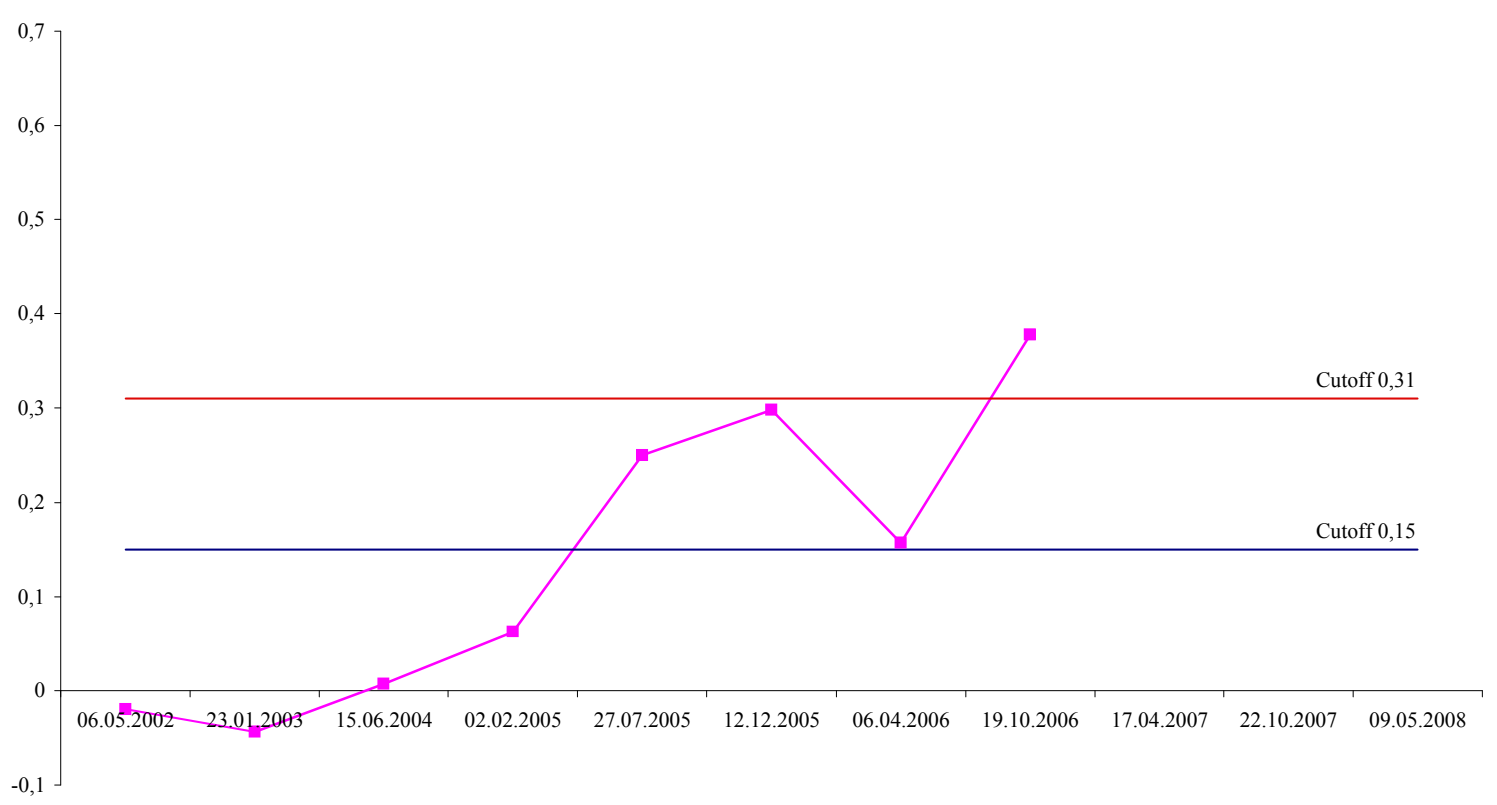

Ohrmarke Nr. 12655

Abb. 47: Grafische Darstellung der Svanovir- und IDEXX-ELISA-Ergebnisse für Ohrmarkennummer 12655 


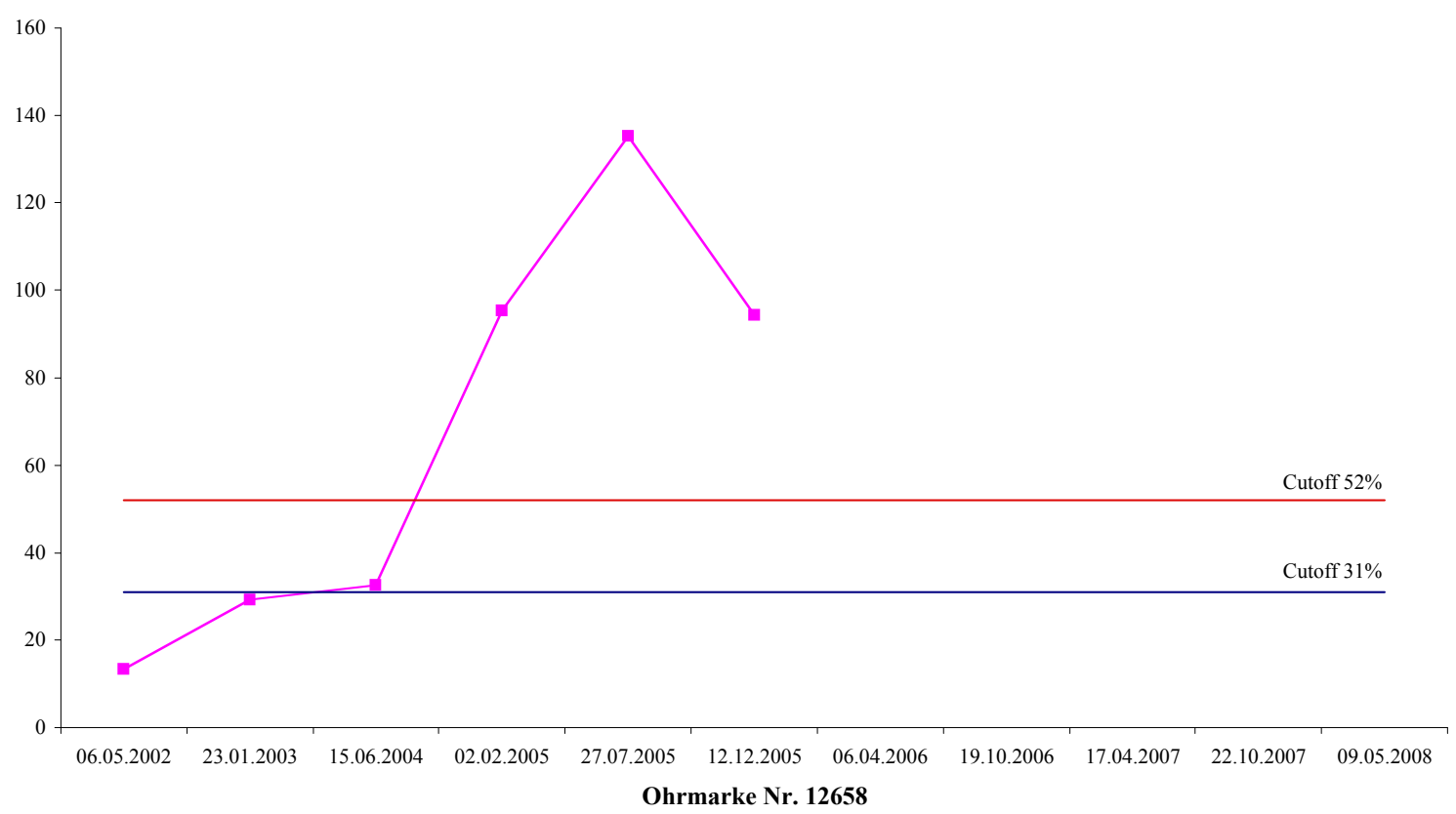

IDEXX-ELISA

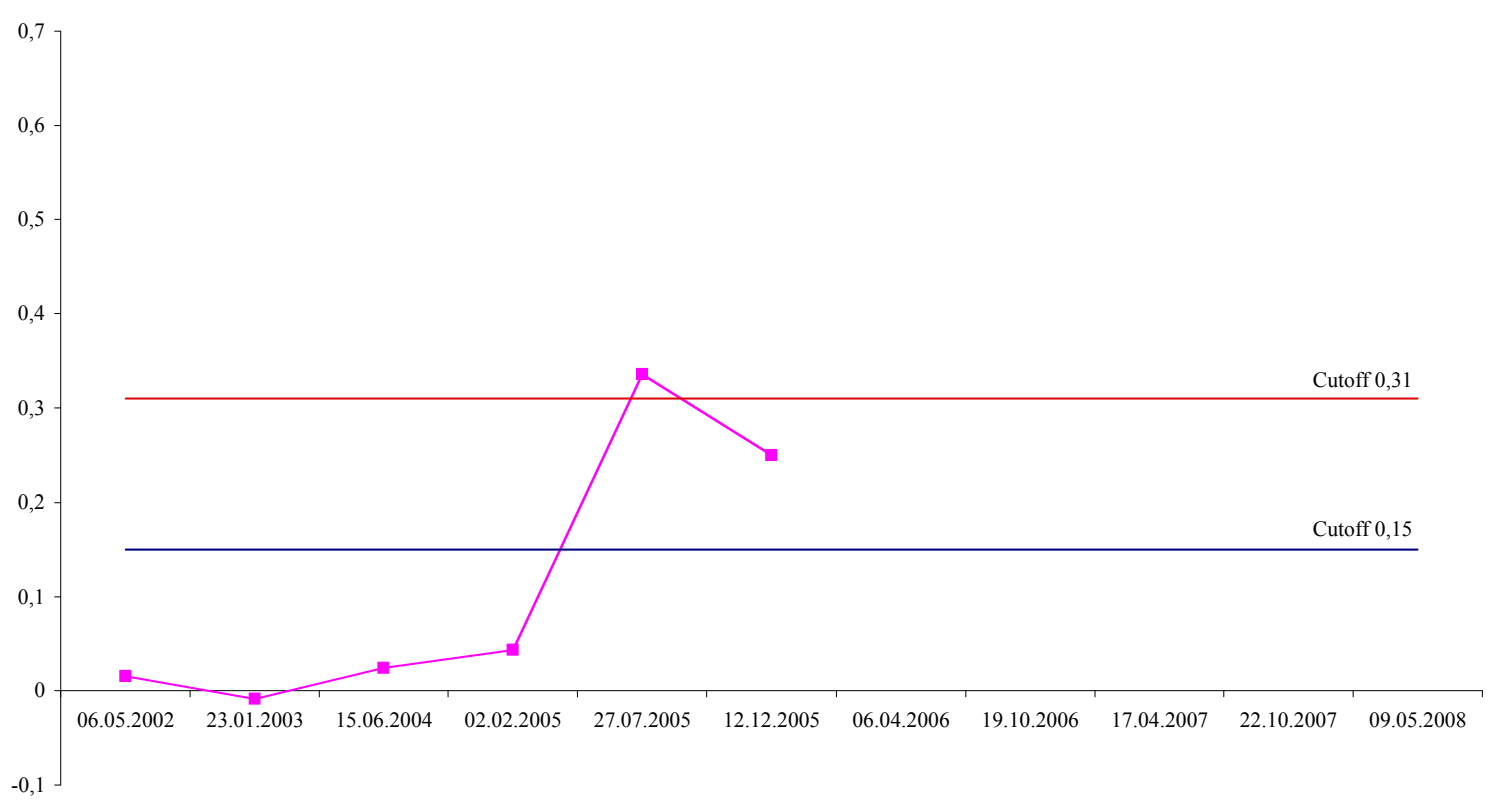

Ohrmarke Nr. 12658

Abb. 48: Grafische Darstellung der Svanovir- und IDEXX-ELISA-Ergebnisse für Ohrmarkennummer 12658 


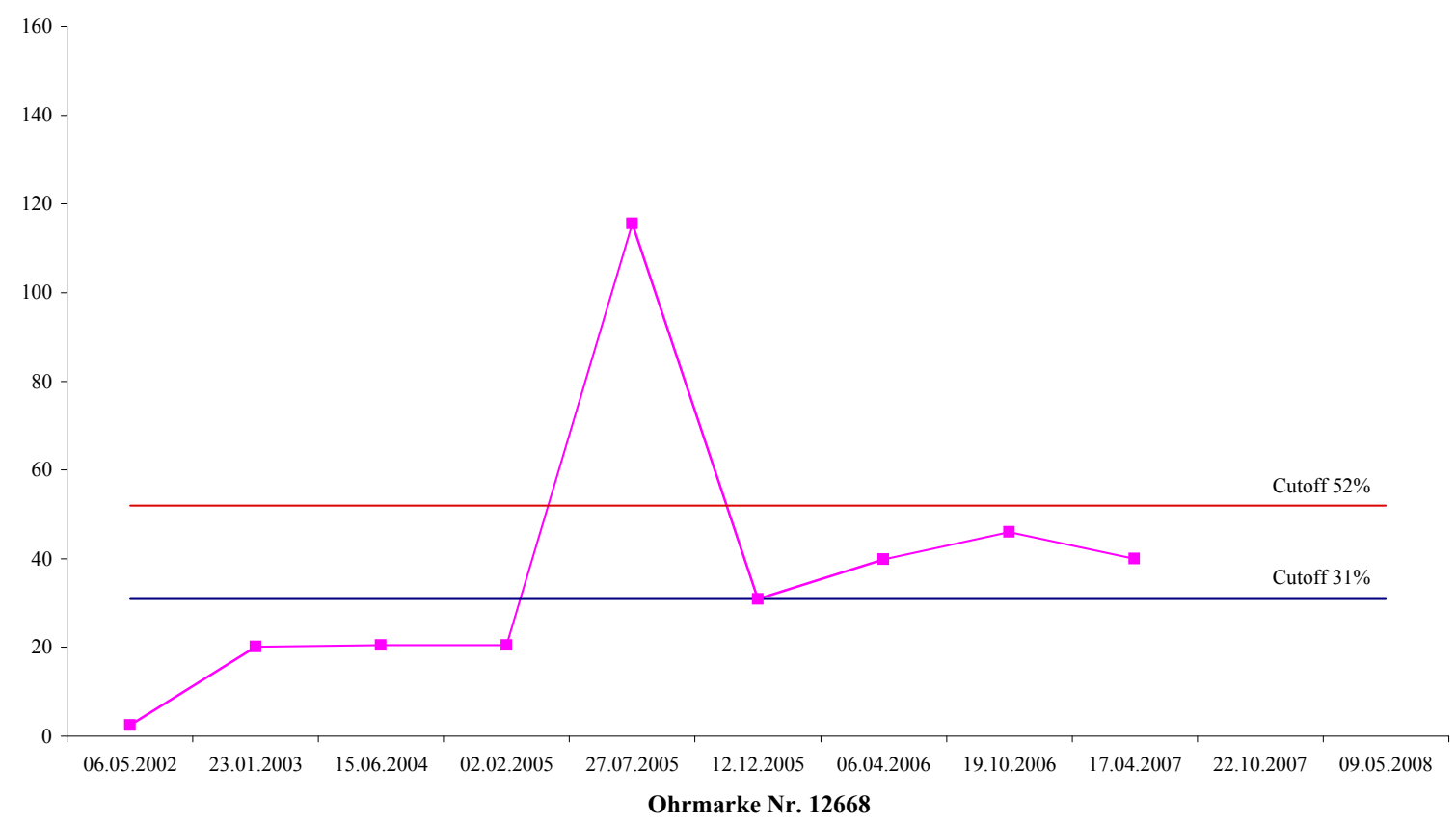

IDEXX-ELISA

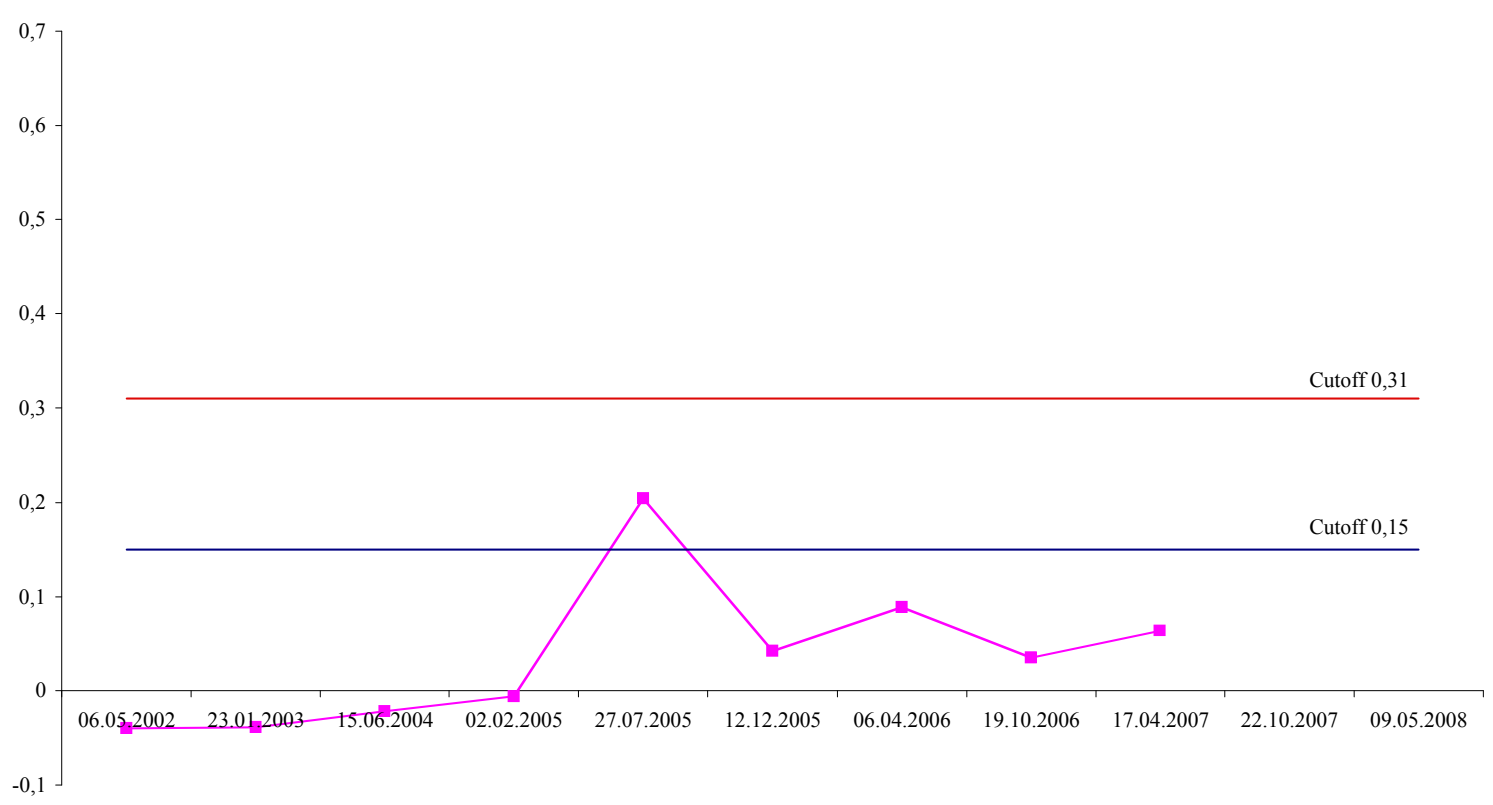

Ohrmarke Nr. 12668

Abb. 49: Grafische Darstellung der Svanovir- und IDEXX-ELISA-Ergebnisse für Ohrmarkennummer 12668 


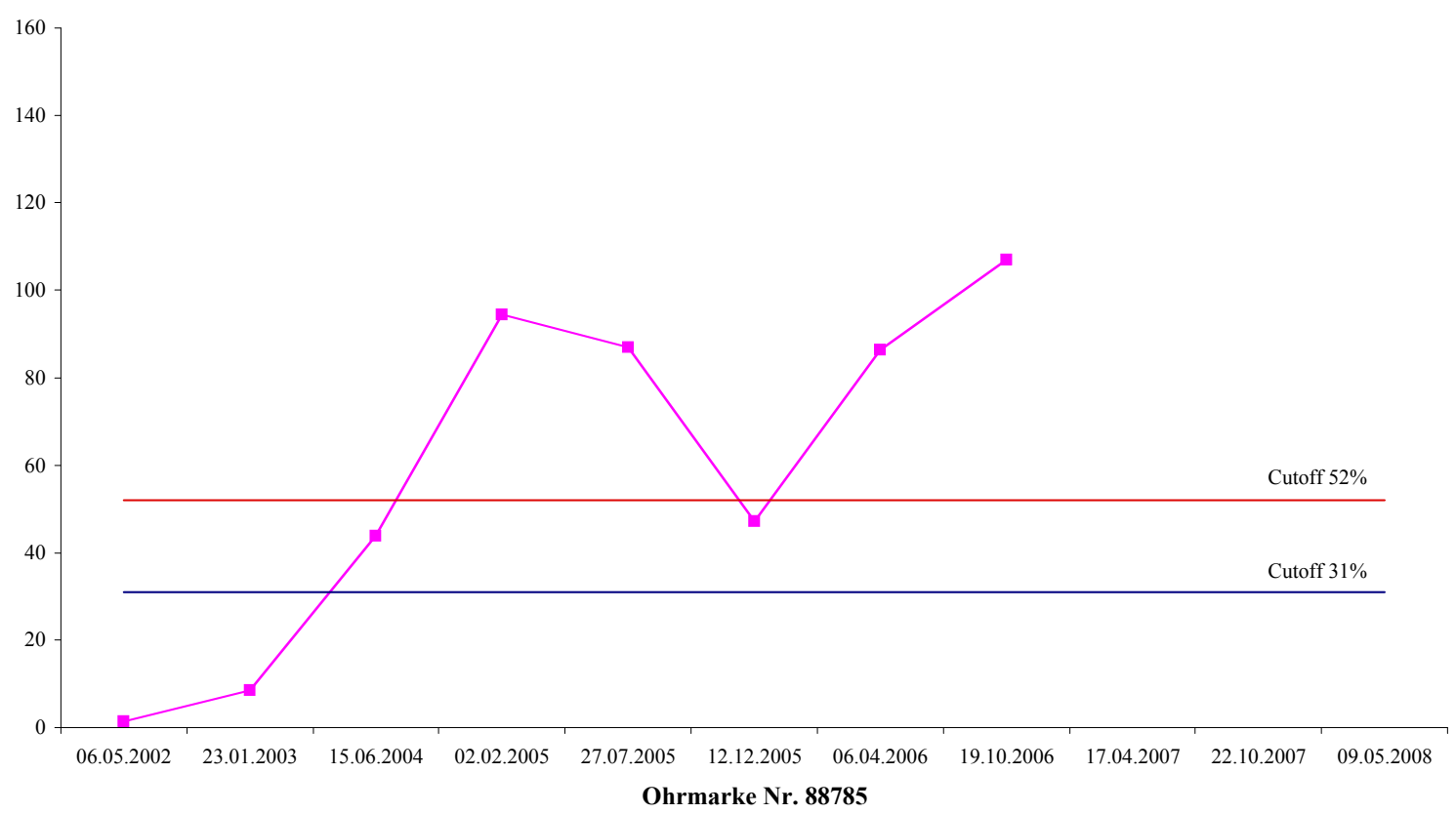

IDEXX-ELISA

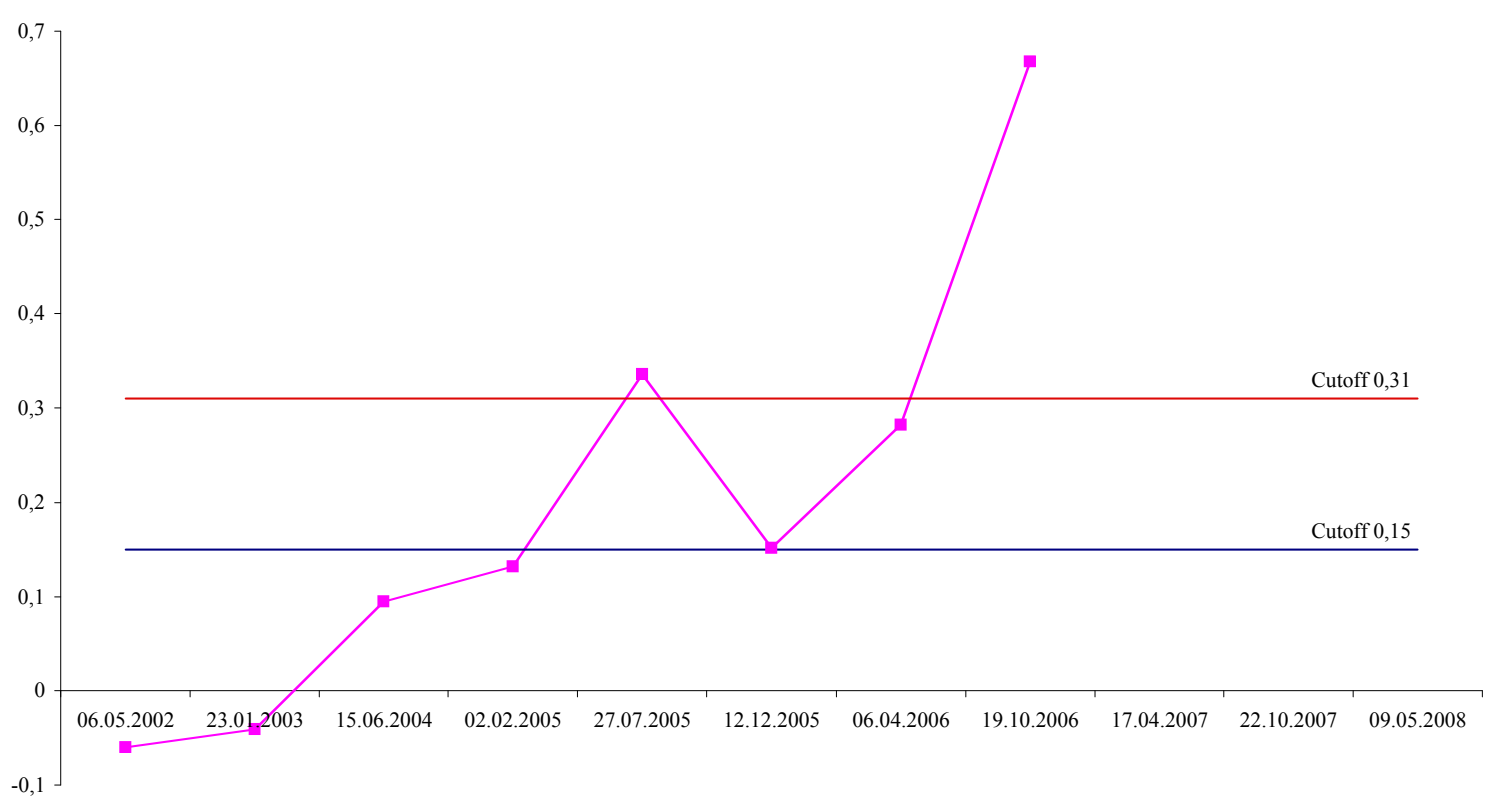

Ohrmarke Nr. 88785

Abb. 50: Grafische Darstellung der Svanovir- und IDEXX-ELISA-Ergebnisse für Ohrmarkennummer 88785 
Die Auswertung mittels GLMM wurde von Dr. S. König, Abteilung Tierzucht und Haustiergenetik, Department für Nutztierwissenschaften der Universität Göttingen durchgeführt.

Abb. 51 zeigt, dass die Daten von SV_dens erwartungsgemäß poissonverteilt vorliegen.

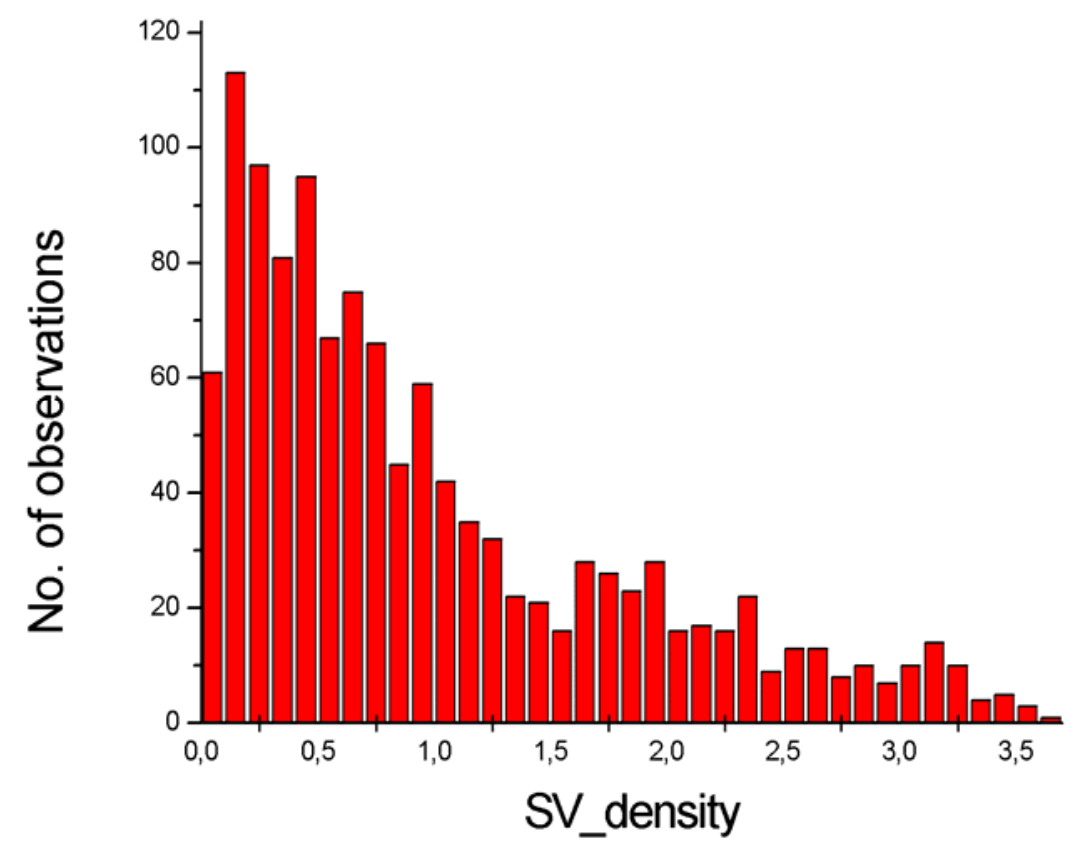

Abb. 51: Verteilung der Messwerte für die optische Dichte des Svanovir-ELISAs

AIC und BIC Informationskriterien sowie der "Likelihood ratio"-Test wurden verwendet, um die beste Kovarianz-Struktur für die Analyse wiederholter Messungen herauszufinden (Tabelle 3). Erheblich kleinere Werte wurden bei der Anwendung der AR(1) Struktur erreicht. Darüber hinaus war der errechnete „likelihood ratio“ Wert größer als die Werte der Chi-QuadratStatistik. Der errechnete statistische Wert war 31. Dieser Wert ist größer als der kritische $\chi^{2}-$ Wert von 10,83 bei $P=0.001$ bei einem Freiheitsgrad von 1 . Daher wurde für die Modellwahl die AR(1) Kovarianz-Struktur berücksichtigt. 
Tabelle 3: Informationskriterium von Akaike (AIC), Bayes\&Schwarz (BIC), 2 log -L Wertes für die $\mathrm{CS}^{1}$ und $\mathrm{AR}(1)$ Kovarianz-Strukturen zur Analyse wiederholter Messungen (kleinere Werte verweisen auf das bessere Modell).

\begin{tabular}{lll}
\hline & \multicolumn{2}{c}{ Kovarianz-Struktur } \\
Kriterium / Parameter & CS & AR(1) \\
\hline AIC & 2,640 & 2,609 \\
BIC & 2,648 & 2,616 \\
$2 \log$-L & 2,636 & 2,605 \\
LRT $^{2}$ & 31 & \\
\hline
\end{tabular}

${ }^{1} \mathrm{CS}$ ist ein einfaches Wiederholbarkeitsmodell mit „,compound symmetry“ Kovarianz-Struktur für Umwelteffekte von SV_density; das AR(1) Modell setzt eine autoregressive Kovarianz-Struktur für die Umwelteffekte von SV density voraus.

${ }^{2}$ LRT $=$ Likelihood Ratio Test Statistik für den Vergleich des CS Modells mit dem AR(1) Modell.

Die Varianzanalyse mit der AR(1) Kovarianz-Struktur für wiederholte Messungen erwies sich als hoch signifikant für den Effekt von ID_dens bis zum Polynom 3. Ordnung $(P<0.001)$. Signifikant $(P<0.001)$ war auch der Alterseffekt. Die starke Abhängigkeit von SV_dens und ID_dens ist in der Kurve in Abb. 52 dargestellt, die aus dem statistischen Modell für Werte von ID_dens im Bereich zwischen 0.1 und 0.5 generiert wurde.

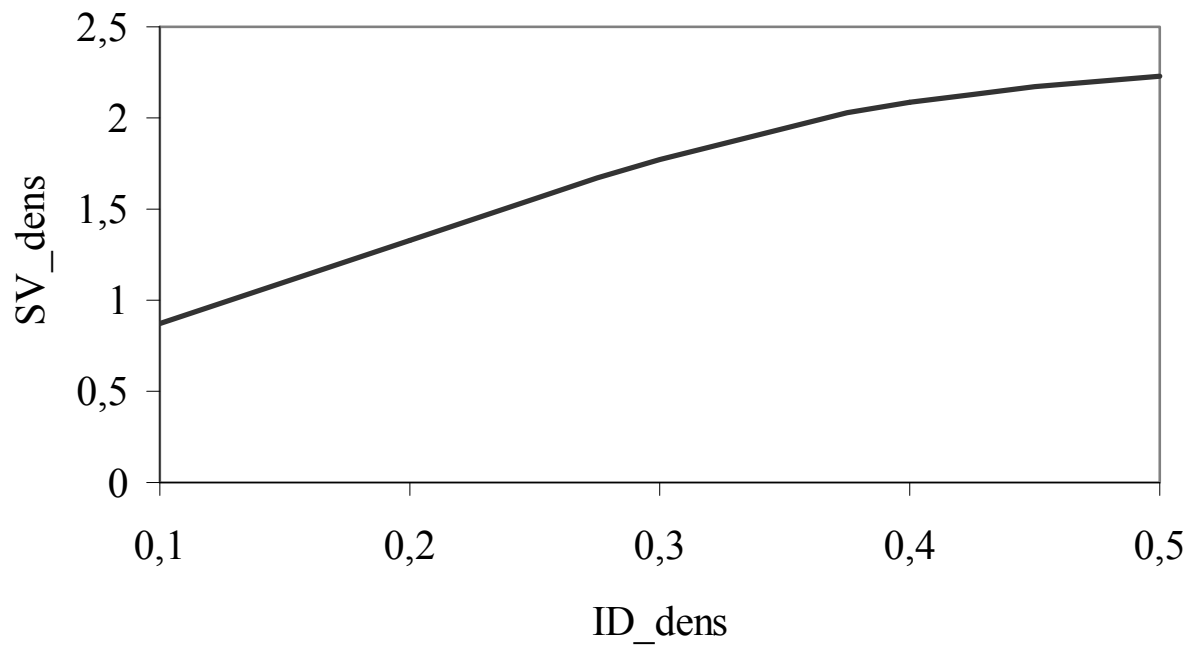

Abb. 52: Retransformierte Werte der „poison like distribution“ der log Verbindungsfunktion für SV_dens (Least-Square-Means) in Abhängigkeit von ID_dens 
Die Paratuberkulose, auch „Johne`sche Krankheit“ genannt, ist eine unheilbare, chronisch verlaufende Infektionskrankheit der Wiederkäuer, welche weltweit verbreitet ist und besonders in Milchrinderbeständen enorme wirtschaftliche Schäden verursacht.

In vielen Ländern werden daher diagnostische Untersuchungen auf Paratuberkulose durchgeführt, um die Herdenprävalenz festzustellen. Einige Länder führen auch bereits Bekämpfungsprogramme durch $(15,136)$. In Niedersachsen wird seit 1990 ein durch die Niedersächsische Tierseuchenkasse geförderter Versuch zur Bestandssanierung Paratuberkuloseinfizierter Milchviehherden durchgeführt. Über einen Zeitraum von fünf Jahren werden in genau definierten Zeitabständen einerseits die Blutproben aller über zwei Jahre alten Milchkühe serologisch mittels ELISA und anderseits die Kotproben kulturell untersucht.

Ziel der vorliegenden Arbeit war es, mit Hilfe serologischer Methoden Kontrolluntersuchungen auf Paratuberkulose durchzuführen, um den Durchseuchungsgrad eines ausgewählten Bestandes zu ermitteln. Die Tiere wurden mit zwei damals in Deutschland zugelassenen ELISA-Methoden (HerdCheck ${ }^{\mathrm{TM}}$ M.pt, IDEXX Laboratories Inc., Maine sowie Svanovir ${ }^{\circledR}$, Svanova Biotech AB, Uppsala) getestet. Die Untersuchungen fanden in einem Betrieb im Raum Göttingen statt. Der Betriebsleiter hatte sich bereit erklärt, an dem von der Niedersächsischen Tierseuchenkasse organisierten Paratuberkulose-Bekämpfungsprogramm teilzunehmen und alle IDEXX-ELISA-positiven Tiere aus dem Betrieb zu entfernen. Die serologischen Untersuchungen sollten zeigen, ob durch Einhaltung der im Rahmen des freiwilligen Bekämpfungsprogrammes in Niedersachsen empfohlenen Hygienemaßnahmen bei gleichzeitiger Entfernung positiv getesteter Tiere der Infektionsdruck in der betroffenen Herde entscheidend gesenkt werden könnte.

Für die Entstehung und Aufrechterhaltung der Paratuberkulose im Bestand spielt die Infektion der Kälber eine entscheidende epidemiologische Rolle. Die Kälber infizieren sich in der Regel kurz nach der Geburt oder in den ersten Lebensmonaten, meistens durch mit Kot verschmutztes Kolostrum, Milch oder Futter. Daher ist es wichtig, auch subklinisch kranke Ausscheidertiere frühzeitig zu erkennen und aus der Herde zu entfernen. Um die Paratuberkulose erfolgreich zu bekämpfen, sollten alle Maßnahmen ergriffen werden, um die Kälber von ihr frei zu halten. Um eine Einschleppung der Seuche zu vermeiden, sollten keine Tiere aus Betrieben zugekauft werden, die von der Paratuberkulose betroffen sind. 
Um die Mindestanforderungen der Hygiene zu erfüllen, wurde im Betrieb „H“ eine strikte Trennung der verschiedenen Altersgruppen vorgenommen und die Tiere in verschiedenen Standorten stationiert. Es wurde ein getrennter Abkalberaum zur Verfügung gestellt, und die Abkalbung fand nur dort auf einer dicken, sauberen Streuschicht statt. Nach der Geburt wurden die Kälber sofort von den Muttertieren getrennt und in Kälberboxen verbracht. Um die Kontamination des Kolostrums zu verhindern, wurde dies erst nach gründlicher Reinigung des Euters gewonnen und sofort dem Kalb gefüttert. Von Reagenten geborene Kälber wurden mit zuvor von negativen Kühen gewonnener und tiefgefrorener Kolostralmilch gefüttert. Um eine Kontamination der Weideflächen mit MAP-Erregern zu verhindern, wurde die Gülle nur auf Ackerflächen verteilt. Die Kälber und Jungtiere wurden mit Silage gefüttert, es konnte jedoch nicht ausgeschlossen werden, dass die Gülle älterer Tiere auf diesen Flächen verteilt worden war. Die Kälber wurden bis zum dritten Lebensmonat in Kälberiglus und in Kälberständen untergebracht, die neben dem Kuhstall lagen. Obwohl die Kälber in einem separaten Raum untergebracht waren, war dieser von dem Milchkuhstall nicht gut getrennt und es bestand die Möglichkeit, dass während der Fütterung Kotreste in den Kälberstall übertragen werden konnten.

Die serologischen Untersuchungen haben gezeigt, dass dieser Betrieb stark verseucht war. Angesichts der guten Milchquote und Milchleistung der Kühe war der Betriebsleiter jedoch nicht immer in der Lage, die betroffenen IDEXX-ELISA-positiven Tiere zu entfernen. So wurden z. B. am 27.07.2005 von 14 IDEXX-ELISA-positiven Reagenten nur 4 entfernt. Wenn die Betriebe nach Paratuberkulosefreiheit streben, sollten keine paratuberkuloseverdächtigen Tiere oder serologische Reagenten eingestellt werden. Im untersuchten Betrieb „ $\mathrm{H}^{\text {“ }}$ wurden jedoch am 18.12.2001 Tiere aus Beständen zugekauft, die nicht Paratuberkulose-frei waren. Darüber hinaus wurden am 18.12.2001 insgesamt 11,96\% Tiere der Herde aus eigener Remonte neu eingestallt, die sowohl im Svanovir- als auch im IDEXX-ELISA Reagenten waren. Weitere 19,57\% der Herde, die Zugänge aus der eigenen Remonte darstellten, und $15,22 \%$ der Herde, die aus zugekauften Tieren bestanden, waren nur im Svanovir-ELISA Reagenten. Am 15.6.2004 wurden sogar 23 Svanovir-Reagenten und 2 IDEXX-Reagenten eingestallt. In diesem Betrieb wurden folglich kontinuierlich Svanovir-Reagenten und manchmal auch IDEXX-ELISA-Reagenten neu eingestellt.

Am 08.02.2000 waren 23,59\% der Tiere gleichzeitig IDEXX-ELISA- und Svanovir-ELISA reaktiv und 58,43\% der Tiere ausschließlich im Svanovir-ELISA reaktiv. Bis zum 02.02.2005 ging der Anteil der IDEXX-Reagenten nach unten und betrug nur noch 2,06\%, im Svanovir- 
ELISA dagegen betrug er noch 51,55\%. Die Anzahl der IDEXX-ELISA-Reagenten stieg am 27.07.2005 wieder nach oben und betrug 33,33\%, im Svanovir-ELISA reagierten 70,83\% der Tiere. Die Anzahl der Reagenten in beiden Tests ging allmählich nach unten und am 09.05.2008 betrug der Anteil reaktiver Tiere im IDEXX-ELISA nur 5,05\% und im SvanovirELISA 52,52\%. Obwohl der Anteil der antikörperfreien Tiere ebenfalls deutlichen Schwankungen unterlag, ging der Trend nach oben, so dass am 09.05.2008 der Anteil antikörperfreier Tiere 47,47\% (Abb. 18) im Vergleich zu 40,45\% am 08.02.2000 betrug. Bei der Untersuchung am 27.07.2005 sind vermutlich sehr viele Tiere zu IDEXX-Reagenten geworden, weil in der Vergangenheit massiv Svanovir-ELISA-Reagenten neu eingestallt worden waren. Von den 32 IDEXX-ELISA-Reagenten waren 11 Tiere bereits am 15.06.2004 als SvanovirELISA-Reagenten (Abb. 5) und 2 Tiere als IDEXX-ELISA-Reagenten eingestallt worden. Am 23.01.2003 sind 3 Tiere als Svanovir-ELISA-Reagenten eingestallt worden, 1 Tier wurde bereits am 06.05.2002 als IDEXX-ELISA-Reagent eingestallt. Es konnte feststellt werden, dass der größte Anteil der Tiere, die bereits als Svanovir-Reagenten zugegangen waren, sich zu IDEXX-ELISA-Reagenten entwickelte, wenn sie lange genug in der Herde blieben (Abb. 22). Der Svanovir-ELISA detektiert folglich die Antikörperbildung bei den Tieren früher als der IDEXX-ELISA, die Reaktion erfolgt somit deutlich zeitversetzt (Abb. 22)

Die Untersuchungen haben auch gezeigt, dass im Svanovir-ELISA die größte Zahl an Reagenten Tiere im Alter zwischen 2-3 Jahren waren, im IDEXX-ELISA jedoch die größte Zahl an Reagenten zwischen 3 und 4 Jahre alt war. Nach Angaben von Socket et al. (1992) detektiert der Svanovir-ELISA mehr Reagenten als der IDEXX-ELISA. Der IDEXX-ELISA ist spezifischer als der Svanovir-ELISA und die Ergebnisse des IDEXX-ELISAs korrelieren besser mit der Ausscheidung von MAP-Erregern (184).

Der Infektionsdruck ging sowohl im Svanovir- als auch im IDEXX-ELISA zurück. Am 08.02.2000 betrug der Mittelwert für die gesamte Herde im Svanovir-ELISA 54,6\% und am 09.05.2008 betrug er 48,9\% (Abb. 27). Im IDEXX-ELISA betrug am 08.02.2000 der Mittelwert für die gesamte Herde 0,08 und am 09.05.2008 betrug er nur -0,006 (Abb. 29). Der Anteil der IDEXX-Reagenten weist eine Korrelation mit dem Mittelwert der Antikörpertiter auf (Abb. 28). Nach einer Entfernung von Reagenten sank auch der durchschnittliche Antikörpertiter (Abb. 29). Die Untersuchungen zeigten, dass jüngere Tiere mit niedrigeren Antikörpertitern reagierten als ältere. So war in den Jahren 2000 bis 2008 der Antikörpertiter bei den 14 jährigen Tieren stets geringer als bei den Tieren ab 4 Jahren (Abb. 28). 
Die Untersuchungen haben weiterhin gezeigt, dass sich bei Tieren innerhalb eines Jahres der serologische Status sowohl im Svanovir- als auch im IDEXX-ELISA mehrfach ändern kann. Einige Tiere, die IDEXX-Reagenten waren, zeigten sich in der nächsten Untersuchung plötzlich antikörperfrei, oder antikörperfreie Tiere waren in der nächsten Untersuchung plötzlich IDEXX-Reagenten. Es gab auch Tiere, die antikörperfrei waren und trotzdem MAP-Erreger mit dem Kot ausschieden. Diese Tatsachen stellen die Idee in Frage, aus antikörperfreien Tieren eine Kolostrumbank zu erstellen. Weil die Paratuberkulose einen intermittierenden Verlauf hat, verläuft die MAP-Ausscheidung ebenfalls intermittierend und der Antikörpertiter unterliegt starken Schwankungen.

Die latente Phase der Paratuberkulose, welche ohne klinische Anzeichen abläuft, dauert 25 Jahre. Es ist noch nicht bekannt, wann die Immunkontrolle sich verschlechtert und die Tiere beginnen, MAP-Erreger auszuscheiden. Es wird vermutet, dass der Verlust der Immunantwort mit der Unterdrückung der zellulären Immunantwort und dem Einsetzen einer starken humoralen Immunantwort verbunden ist (104). Im Anfangsstadium der Infektion entwickeln die Tiere zuerst eine zelluläre Immunantwort. Mit Übergang von der subklinischen zur klinischen Phase der Krankheit schwindet die zelluläre Immunantwort und eine starke humorale Immunantwort tritt in Erscheinung (13). Die effektive Immunantwort gegen diese Krankheit ist durch die zelluläre Immunantwort bedingt, da die humorale Immunantwort keinen Schutz bietet (28). Erst mit der Entwicklung der Krankheit von der subklinischen zur klinischen Phase verändert sich gleichzeitig die Immunantwort von der zellulären zur humoralen Schiene (187-189, 203). Diese Tatsache macht die Detektion subklinisch an Paratuberkulose erkrankter Tieren mit Hilfe der ELISA-Technik schwierig (203).

Die Untersuchungen einer Forschergruppe aus den USA zeigten jedoch, dass die humorale Immunantwort bereits parallel zu der zellulären Immunantwort detektierbar ist, wenn ein auf LAM basierender ELISA verwendet wurde. Um die humorale und zelluläre Immunantwort bei den Rindern besser untersuchen zu können, wurden 3 Kälbern, welche jeweils zwei Wochen alt waren, vier Wochen lang einmal wöchentlich 4x $10^{6} \mathrm{KBE}$ MAP-Erreger in beide Tonsillen injiziert. Während der postchallenge Untersuchungen am Tag 146, 167 und 271 schieden die entsprechenden Tiere geringe Mengen (1 bis 4 Kolonien pro Schrägagar) MAPErreger mit dem Kot aus. Bei keinem der Tiere wurden bis zur Aussetzung der Untersuchung am 320ten Tag klinische Anzeichen der Paratuberkulose festgestellt. Der Einsatz auf LAMbasierender ELISAs detektierte im Gegensatz zur bis heute herrschenden Meinung eine humorale Immunantwort parallel zur zellulären Immunantwort ab dem 134ten Tag postchallen- 
ge bei allen Tieren. Der Einsatz des kommerziell erhältlichen IDEXX-ELISAs hatte während der ganzen Untersuchungsperiode keine humorale Immunantwort bei einem der untersuchten Tiere feststellen können (219). Auf LAM-basierende ELISAs demonstrierten bereits ihre Nützlichkeit bei der Diagnostik von durch Mycobakterien - einschließlich MAP - verursachten Infektionen (94, 103, 198-200). Die Untersuchungen von Koets zeigten auch, dass im klinischen Stadium der Krankheit die LAM-spezifische Immunantwort gegen Paratuberkulose verringert war (103).

In einem Ringversuch wurden Serumproben mit drei ELISA-Testsystemen (IDEXX, Pourquier und Svanovir) untersucht. Die Untersuchungen zeigten, dass der Svanovir-ELISA infizierte Tiere in einer früheren Phase der Infektion erkennt als die anderen Tests. Wenn die Tiere schon in der subklinischer Phase als infiziert erkannt würden, könnten sie rechtzeitig aus der Herde entfernt werden, bevor sie beginnen, MAP-Erreger in großen Mengen auszuscheiden und die Umwelt zu kontaminieren (21).

In einer Dissertation (134) wurde die diagnostische Wertigkeit des Pourquier ${ }^{\circledR}$-ELISAs und Svanovir ${ }^{\circledR}$-ELISAs untersucht. Der Unterschied zwischen beiden Testsystemen bestand darin, dass im Pourquier-Test die Serumproben zur Minimierung möglicher Kreuzreaktionen präadsorbiert werden, während im Svanovir-Test unbehandelte Serumproben untersucht werden können. Es wurden 38 definierte Seren untersucht. Im Svanovir ${ }^{\circledR}$-ELISA waren 20 Tiere positiv. Aus diesen 20 Tieren waren im Pourquier ${ }^{\circledR}$-ELISA nur 6 Tiere positiv. Nach der Präadsorption der Serumproben mit M. phlei waren im Svanovir ${ }^{\circledR}$-ELISA sieben Tiere positiv. Aus diesen 7 Tieren waren im Pourquier $^{\circledR}$-ELISA nur fünf Tiere positiv. Die Versuche zeigten, dass die hohe Spezifität des Pourquier-ELISAs durch Präadsorption mit M. phlei bedingt war. In einer Dissertation zur Etablierung eines Milch-ELISAs wurde ein Ringversuch, an dem sieben Untersuchungsstellen in Niedersachsen beteiligt waren, durchgeführt. In diesem Versuch wurden drei ELISA-Testkits anhand von 60 Seren, die von 10 klinisch verdächtigen Tieren zu verschiedenen Zeitpunkten genommen worden waren, miteinander verglichen. Mittels Kultur des Ileocaecallymphknotens konnte bei sechs Tieren MAP nachgewiesen werden. Bei einem weiteren Tier wurde in der Milchuntersuchung die Ausscheidung des Erregers mit der Milch mittels PCR bewiesen. Bei drei der klinisch verdächtigen Tiere war ein kultureller Nachweis des Erregers im Ileocaecallymphknoten nicht möglich. Die Untersuchungen zeigten, dass nur der Svanovir ${ }^{\circledR}$-ELISA (Svanova, Schweden) jedes der Lymphknoten-Kulturpositiven Tiere sowie nur in der Milch-PCR positive Tiere erkennt und dies schon in der ersten Untersuchungswoche. Von den übrigen klinisch verdächtigen Tieren wurde eine Kuh im gesamten Untersuchungszeitraum von allen teilnehmenden Untersuchungsstellen als negativ 
beurteilt. Zwei weitere klinisch verdächtige Tiere wurden überwiegend von allen Untersuchungsstellen als zweifelhaft ermittelt. Es wurde festgestellt, dass die Reproduzierbarkeit der Ergebnisse der Untersuchungsstellen beim Svanovir ${ }^{\circledR}$-ELISA im Vergleich zu anderen ELISAs uneingeschränkt gut war (228). Die positive Beurteilung aller im „Goldstandard“ (Ileocaecallymphknoten-Kultur) positiven Tiere und eine frühe Erkennung auch schon subklinisch erkrankter Tiere stimmt mit früheren Ergebnissen zur Validierung des ELISAs mittels Ileocaecallymphknoten-Kultur überein (93). Er konnte demonstrieren, dass der Svano$\operatorname{vir}^{\circledR}$-ELISA insbesondere Tiere im relativ frühen Stadium der Infektion erkennt, bevor die Tiere beginnen, den Erreger kontinuierlich im Kot auszuscheiden.

Im Rahmen eines Paratuberkulosebekämpfungsprogramms in Nordrhein-Westfalen wurde eine Dissertation durchgeführt (216). In dieser Arbeit wurden Serumproben aus Rindern mit dem HerdCheck ${ }^{\mathrm{TM}}$ M.pt Ab-ELISA und mit dem Svanovir ELISA ${ }^{\circledR}$ untersucht und miteinander verglichen. 22 Rinder wurden mittels Kotkultur positiv getestet. Von diesen 22 Rindern standen 35 Seren zur Verfügung. Im Svanovir-ELISA reagierten von 35 Seren 20 Seren positiv. Im IDEXX-ELISA reagierten von 35 Seren nur 11 Tiere positiv. Weil sich die Ergebnisse der serologischen Untersuchung voneinander so stark unterschieden, vermutete der Autor, dass der Svanovir-ELISA infizierte Tiere früher erkennt als der IDEXX-ELISA.

Unsere Untersuchungen zeigten, dass der Anteil der serologischen IDEXX-ELISA-Reagenten im jüngeren Tierbestand (1-4 Jahre) geringer war als in der Gruppe der Tiere über 4 Jahre. Die Untersuchungen von Meyer zu Vilsendorf zeigten, dass im Johnin-Test der größte Anteil der Reagenten im Alter von zwei bis drei Jahren waren (128). In der KBR, im ELISA und bei der kulturellen Untersuchung war der größte Teil der Tiere im Alter von vier bis fünf Jahren. Dies könnte damit zu erklären sein, dass sich eine zelluläre Abwehr mit zunehmendem Alter der untersuchten Tiere seltener nachweisen lässt, während bei älteren Tieren häufiger Antikörper festgestellt werden.

Nach Meyer zu Vilsendorf sind unter den Jungtieren bis zu vier Jahren Ausscheider seltener zu finden als bei älteren Tieren. Auch bei der Organuntersuchung von Schlachttieren wurden die meisten positiven Ergebnisse in der Altersstufe der vier-bis fünfjährigen Rinder festgestellt.

Die ergänzende Untersuchung von Kotproben am 19.10.2006 mit Hilfe der PCR hatte gezeigt, dass die 7 Tiere mit den Ohrmarken 07347, 12645, 88797, 88807, 50482, 18707, 50506 den MAP-Erreger mit dem Kot ausschieden, aber serologisch im Svanovir- und IDEXX-ELISA antikörperfrei waren. Bei der nächsten Untersuchung am 17.04.2007 waren die 2 Tiere mit 
den Ohrmarken 07347 und 18707 aus der Herde entfernt, das Tier mit der Ohrmarke 88797 schied den MAP-Erreger mit dem Kot aus und die restlichen 4 Tiere mit den Ohrmarken 12645, 88807, 50482, 50506 schieden keinen MAP-Erreger mehr mit dem Kot aus. Die Milchkuh mit der Ohrmarke 12645 war jedoch im Svanovir-ELISA-Reagent geworden. Am 22.10.2007 war das Tier mit der Ohrmarke 88797 aus der Herde abgeschafft worden und die restlichen Tiere mit den Ohrmarken 12645, 88807, 50482, 50506 schieden mit dem Kot keinen MAP-Erreger mehr aus. Die Milchkuh mit der Ohrmarke 12645 blieb im SvanovirELISA reaktiv. Die PCR-Untersuchung am 09.05.2008 zeigte, dass die Tiere mit den Ohrmarken 12645, 88807, 50482, 50506 keinen MAP-Erreger mit dem Kot ausschieden, aber bei allen Tieren konnten nun Antikörper mit Hilfe des Svanovir-ELISAs festgestellt werden. Diese Untersuchungen zeigen, dass die Tiere bereits MAP-Erreger mit dem Kot ausscheiden, bevor Antikörper mit serologischen Methoden festgestellt werden können und bestätigen erneut die Tatsache, dass der MAP-Erreger intermittierend ausgeschieden wird.

Die Korrelation der serologischen ELISA-Ergebnisse im Svanovir- und im IDEXX-ELISA auf der Basis von 1915 Tieren mit der Microsoft Excel Programm Funktion „Korrel“ betrug für die Werte der optischen Dichte 0,50 und für die Messwerte in Prozent 0,59. Aus diesen niedrigen Korrelationskoeffizienten wurde ursprunglich eine schlechte Vergleichbarkeit der Testsysteme abgeleitet und die These aufgestellt, dass der Svanovir-ELISA einen hohen Anteil falsch-positiver Ergebnisse erzeugt. Die Berechnung der Korrelation serologischer ELISA-Ergebnisse mittels GLMM für 1210 Tiere zeigte jedoch, dass eine deutliche Korrelation zwischen beiden Testergebnissen besteht, wenn das Alter der Tiere und die gesamte Untersuchungszeitspanne berücksichtigt werden. Die Ergebnisse des GLMM bestätigen zusätzlich, dass der Svanovir-ELISA auch ein qualitativ guter ELISA ist, der Reagenten viel früher als andere ELISAs detektiert. Dies bestätigt auch die Ergebnisse anderer Forscher, die festgestellt hatten, dass der Svanovir-ELISA in der Lage ist, bereits die Phase der rein zellulären Immunantwort zu detektieren.

Obwohl in diesem Betrieb nicht alle Management- und Hygienemaßnahmen strikt eingehalten wurden, nicht alle IDEXX-ELISA positiven Tiere aus der Herde fristgerecht abgeschafft werden konnten und zu viele Svanovir- und IDEXX-ELISA Reagenten neu eingestallt wurden, ist es gelungen, durch Verwendung serologischer Testverfahren die Infektionsrate deutlich zu senken. 
Die Ergebnisse unserer Untersuchungen zeigen, dass es mit der Anwendung serologischer Testverfahren und Kot-Pool-PCR zwar möglich ist, viele Ausscheidertiere und subklinisch kranke Tiere zu detektieren, die Abschaffung aller betroffenen Tiere aus wirtschaftlichen Gründen jedoch in der Regel nicht realisierbar ist. Im Betrieb „ $\mathrm{H}^{\text {“ }}$ waren in den ersten Untersuchungen im IDEXX-ELISA 20-30\% der Tiere infiziert. Im Svanovir-ELISA waren 60-70\% der Tiere Reagenten. Ein stark verseuchter Betrieb ist schon allein deshalb nicht in der Lage, alle Reagenten auf einmal abzuschaffen, weil kaum definierte paratuberkulosefreie Betriebe vorhanden sind, woher neue Jungtiere gekauft werden können. Das führt dazu, dass die Bekämpfung der Paratuberkulose langwierig und sehr kostspielig wird.

Die Bekämpfung der Paratuberkulose ist darüber hinaus sehr schwierig, weil die zugelassenen diagnostischen Testverfahren, die zur Zeit zur Verfügung stehen, nicht in der Lage sind, die Infektion bereits in einem Stadium festzustellen, wo die Tiere noch keinen Erreger ausscheiden. Die Infektiosquelle sind jedoch solche Tiere, welche den MAP-Erreger über den Kot ausscheiden und die Umgebung verseuchen.

Um die Weiterverbreitung der Krankheit zu verhindern, sollte mit vorhandenen diagnostischen Tests die Infektionsrate in den Herden möglichst stark gesenkt werden, damit die Schäden, die durch Paratuberkulose entstehen, sich in wirtschaftlich vertretbaren Grenzen halten.

Die Untersuchungen von Dorshorst zeigten darüberhinaus, dass die Anwendung eines verbesserten Hygienemanagements Grundbedingung ist, um die Verbreitung der Paratuberkulose zu verhindern und dabei noch kosteneffektiver ist als die Anwendung diagnostischer Testverfahren. Für viele Herden sind kostengünstige diagnostische Testmethoden nützlicher als sensitivere, aber kostspielige Testverfahren. Der Autor empfiehlt, die Reagenten im Anfangsstadium der Krankheit noch in der Herde zu halten, um Einkommen zu generieren. In solchen Fällen wären gutes Management und strikte Einhaltung der Hygieneregeln eine wichtige Strategie (58).

In einem stark verseuchten Betrieb sollten zuerst die Kot-Pool-PCR und zusätzlich serologische Tests wie der IDEXX-ELISA verwendet werden, damit möglichst viele erkrankte Tiere identifiziert werden, die in einem fortgeschrittenen Stadium sind. In den nachfolgenden Untersuchungen, wenn die Identifizierung der Reagenten schwierig wird, sollten noch sensitivere Tests wie der Svanovir-ELISA eingesetzt werden.

Um eine Neueinschleppung zu verhindern, sollten Tiere nur aus Paratuberkulosefreien Beständen zugekauft werden. Wenn solche Betriebe nicht vorhanden sind, sollte der Zukauf auf über zwei Jahre alte Tiere beschränkt werden, bei denen eine Untersuchung mit den verfügbaren diagnostischen Methoden negative Ergebnisse liefert. Um die Verbreitung der Paratuber- 
kulose zu verhindern, sollten Maßnahmen ergriffen werden, damit von der Paratuberkulose betroffene Betriebe eigene Jungtiere nicht zu anderen Milchbetrieben verkaufen dürfen. Für den Export oder Import der Tiere sollte auch der Svanovir-ELISA eingesetzt werden, damit die Tiere identifiziert werden, bei denen die Krankheit noch im Anfangsstadium ist. 
Ein Milchviehbestand im Raum Göttingen wurde mit zwei damals in Deutschland zugelassenen ELISA-Tests untersucht. Die Untersuchungen zeigten, dass der Betrieb mit Paratuberkulose stark verseucht war. Der Anteil von Svanovir-ELISA-Reagenten unterlag dabei Schwankungen. Er war am 18.12.2001 am höchsten (77,2\%), dann sank er wieder und betrug am 02.02.2005 noch 51,6\%. Am 27.07.2005 ging er wieder nach oben (70,7\%). In der letzten Untersuchung am 09.05.2008 betrug er immer noch 52,5\%. Im IDEXX-ELISA betrug die Infektionsrate am 08.02.2000 23,6\%. Nach der Entfernung der Reagenten fiel der Anteil zum 02.02.2005 auf 2,1\%, um am 27.07.2005 wieder anzusteigen (33,3\%). In der letzten Untersuchung am 09.05.2008 betrug er nur noch 5,1\%. Damit ist es durch die Entfernung positiver Tiere und Einhaltung von Hygienemaßnahmen gelungen, den Infektionsdruck innerhalb von acht Jahren von 23,6\% auf 5,1\% zu senken. Einige Tiere waren MAP-Ausscheider, obwohl bei ihnen serologisch keine Antikörper nachweisbar waren. Die Beobachtungen zeigten, dass bei jeder Untersuchung eine große Anzahl der Tiere im Vergleich zur vorigen Untersuchung ihren Antikörperstatus verändert hatte. Jüngere Tiere reagierten dabei mit niedrigeren Antikörpertitern als ältere. So lagen die mittleren Verhältnisse der Probenwerte zur Positivkontrolle im IDEXX-ELISA bei 1 bis 4 jährigen Tieren bei einem Maximum von 0,12, während bei den über 4 Jahre alten Tieren Werte bis zu 0,21 erreicht wurden. Dies bestätigte sich auch bei den prozentualen Probenwerten im Svanovir-ELISA (Höchstwerte bei 1 bis 4 jährigen Tieren: 60,0\%, bei über 4 Jahre alten Tieren: 101,7\%).

Um die Korrelation der beiden ELISAs zu bestimmen, wurde auch eine Varianz-Analyse mittels Generalised Linear Mixed Model angewendet. Die grafische Darstellung der serologischen Ergebnisse von Svanovir-ELISA und IDEXX-ELISA zeigte, dass die Kurven einen ähnlichen Verlauf hatten, was ein Anzeichen für eine gute Testkorrelation war. Es stellte sich heraus, dass Svanovir- und IDEXX-ELISA zeitversetzt miteinander korrelieren. Die Tiere reagieren zuerst im Svanovir-ELISA und nach einiger Zeit in der Regel auch im IDEXXELISA.

Es konnte hier gezeigt werden, dass in stark verseuchten Betrieben die Abschaffung aller positiven Tiere zum wirtschaftlichen Ruin des Betriebes führen kann. Mit Hilfe der zurzeit zur Verfügung stehenden diagnostischen Mittel ist es jedoch möglich, den Infektionsdruck in den Betrieben deutlich zu senken und die wirtschaftlichen Verluste zu minimieren. Die vollständige Sanierung der Betriebe wird jedoch schwierig bleiben. 
In the rural area of Göttingen a dairy herd known for its Johne's disease history participated in a voluntary control programme. Over a period of eight years, all dairy cows were tested serologically using two different certified ELISA assays. Serologic results revealed a high infestation with paratuberculosis. The proportion of Svanovir-reactors showed a high variation. In December 2001 the percentage of reactive animals was very high (77.2\%). Afterwards the prevalence decreased to $51.6 \%$ in February 2005, only to increase once more in July 2005 to reach 70.7\%. The final sampling date in May 2008 still revealed 52.5\% seropositive cows in the Svanovir-ELISA. Using the IDEXX-ELISA, only $23.6 \%$ of the herd were reactive in February 2000. After the removal of the IDEXX-reactors, the proportion of reactive animals declined to $2.1 \%$ in February 2005 and increased to a prevalence of $33.3 \%$ in July 2005. The sampling in May 2008 finally yielded in 5.1\% IDEXX-reagents. Hence, the elimination of IDEXX-reactive animals and the application of strict hygiene standards resulted in a significant reduction of the infection level within eight years, reflected by the number of reactors.

Some animals revealed to be seronegative MAP-shedders. As shown by the present data, the antibody level of an animal shows an oscillating course and might even yield in a contrariwise result when compared to prior tests. Younger animals usually had lower antibody titres than elderly individuals. The sample of positive control ratio for IDEXX tests amounted to 0.12 in the group of younger animals while the value was 0.21 within the group of older cows. This was also seen for Svanovir-ELISA, where the antibody levels in younger animals had an average value of $60 \%$ compared to a value of $101.7 \%$ seen in cows older than 4 years. The correlation of both ELISAs was calculated with the GLMM (generalised linear mixed model). The graphical representation of serological results gained from IDEXX and Svanovir demonstrated a similar curve progression, which can be seen as a sign of good test correlation. The GLMM revealed a good, but time delayed correlation between both ELISAs. In most cases, Svanovir-ELISA detected reagents a few months earlier than the IDEXX-ELISA. Seroconversion in the IDEXX-ELISA was observed in all Svanovir-reactors given that they remained in the herd. The study showed that in heavily infected herds the abolishment of all reagents is infeasible since it will lead to the economic ruin of the respective farm. In conclusion, it must be stated that, based on the currently available diagnostic tools, the paratuberculosis prevalence can be significantly reduced and economic losses can be minimized. Nevertheless, the complete sanitation of infected herds and a successful eradication of MAP from contaminated premises are out of reach at the moment. 
1. Ahrens, P., S. B. Giese, J. Klausen, and N. F. Inglis. 1995. Two markers, IS901IS902 and p40, identified by PCR and by using monoclonal antibodies in Mycobacterium avium strains. J Clin Microbiol 33:1049-53.

2. Akaike, H. 1973. Presented at the 2nd Int. Symp. Information Theory, Budapest, Hungary.

3. Altic, L. C., M. T. Rowe, and I. R. Grant. 2007. UV light inactivation of Mycobacterium avium subsp. paratuberculosis in milk as assessed by FASTPlaqueTB phage assay and culture. Appl Environ Microbiol 73:3728-33.

4. Anderson, J. L., J. K. Meece, J. J. Koziczkowski, D. L. Clark, Jr., R. P. Radcliff, C. A. Nolden, M. D. Samuel, and J. L. Ellingson. 2007. Mycobacterium avium subsp. paratuberculosis in scavenging mammals in Wisconsin. J Wildl Dis 43:302-8.

5. APHIS 2008, posting date. Johne's disease on US dairies 1991-2007. National Animal Health Monitoring Systems, dairy study 2007. [Online.]

6. Bang, B. 1906. Chronische pseudotuberkulöse Darmentzündung beim Rinde. Berlin Tierärztl Wochenschr 42:759-63.

7. Bang, B. 1910. Über die Anwendung des von Geflügeltuberkelbazillen gebildeten Tuberkulins als Diagnostikum bei der pseudotuberkülosen enteritis des Rindes., Ref. in Jahresbericht Vet Med 30, 88 ed. Maanedsskrift for Dyrläger 21, 561.

8. Bauerfeind, R., S. Benazzi, R. Weiss, T. Schliesser, H. Willems, and G. Baljer. 1996. Molecular characterization of Mycobacterium paratuberculosis isolates from sheep, goats, and cattle by hybridization with a DNA probe to insertion element IS900. J Clin Microbiol 34:1617-21.

9. Beard, P. M., M. J. Daniels, D. Henderson, A. Pirie, K. Rudge, D. Buxton, S. Rhind, A. Greig, M. R. Hutchings, I. McKendrick, K. Stevenson, and J. M. Sharp. 2001. Paratuberculosis infection of nonruminant wildlife in Scotland. J Clin Microbiol 39: 1517-21.

10. Beaudeau, F., M. Belliard, A. Joly, and H. Seegers. 2007. Reduction in milk yield associated with Mycobacterium avium subspecies paratuberculosis (Map) infection in dairy cows. Vet Res 38:625-34.

11. Bech-Nielsen, S., J. B. Jorgensen, P. Ahrens, and N. C. Feld. 1992. Diagnostic accuracy of a Mycobacterium phlei-absorbed serum enzyme-linked immunosorbent assay for diagnosis of bovine paratuberculosis in dairy cows. J Clin Microbiol 30:613-8.

12. Benazzi, S., M. el Hamidi, and T. Schliesser. 1996. Paratuberculosis in sheep flocks in Morocco: a serological, microscopical and cultural survey. Zentralbl Veterinarmed B 43:213-9.

13. Bendixen, P. H. 1978. Immunological reactions caused by infection with Mycobacterium paratuberculosis. A review. Nord Vet Med 30:163-8.

14. Benedictus, G., and J. Bosma. 1985. The intravenous administration of johnin in the diagnosis of paratuberculosis in practice. Vet Q 7:139-45.

15. Benedictus, G., J. Verhoeff, Y. H. Schukken, and J. W. Hesselink. 2000. Dutch paratuberculosis programme history, principles and development. Vet Microbiol 77:399-413.

16. Besra, G. S., and D. Chatterjee. 1994. Lipids and carbohydrates of M. tuberculosis., p. 285-299. In B. Bloom (ed.), Tuberculosis pathogenesis, protection and control. ASM Press, Washington, D.C.

17. Brennan, P. J., and H. Nikaido. 1995. The envelope of mycobacteria. Annu Rev Biochem 64:29-63.

18. Buergelt, C. D., and J. R. Duncan. 1978. Age and milk production data of cattle culled from a dairy herd with paratuberculosis. J Am Vet Med Assoc 173:478-80. 
19. Buergelt, C. D., A. W. Layton, P. E. Ginn, M. Taylor, J. M. King, P. L. Habecker, E. Mauldin, R. Whitlock, C. Rossiter, and M. T. Collins. 2000. The pathology of spontaneous paratuberculosis in the North American bison (Bison bison). Vet Pathol 37:428-38.

20. Bush, R. D., P. A. Windsor, and J. A. Toribio. 2006. Losses of adult sheep due to ovine Johne's disease in 12 infected flocks over a 3-year period. Aust Vet J 84:246-53.

21. Böttcher, J., and A. Gangl. 2004. Mycobacterium avium ssp. paratuberculosisCombined Serological Testing and Classification of Individual Animals and Herds. J Vet Med B 51:443-48.

22. Chamberlin, W., G. Ghobrial, M. Chehtane, and S. A. Naser. 2007. Successful treatment of a Crohn's disease patient infected with bacteremic Mycobacterium paratuberculosis. Am J Gastroenterol 102:689-91.

23. Chaparas, S. D. 1982. The immunology of mycobacterial infections. Crit Rev Microbiol 9:139-97.

24. Chi, J., J. A. VanLeeuwen, A. Weersink, and G. P. Keefe. 2002. Direct production losses and treatment costs from bovine viral diarrhoea virus, bovine leukosis virus, Mycobacterium avium subspecies paratuberculosis, and Neospora caninum. Prev Vet Med 55:137-53.

25. Chiodini, R. J. 1993. Abolish Mycobacterium paratuberculosis strain 18. J Clin Microbiol 31:1956-8.

26. Chiodini, R. J. 1990. Characterization of Mycobacterium paratuberculosis and organisms of the Mycobacterium avium complex by restriction polymorphism of the rRNA gene region. J Clin Microbiol 28:489-94.

27. Chiodini, R. J. 1989. Crohn's disease and the mycobacterioses: a review and comparison of two disease entities. Clin Microbiol Rev 2:90-117.

28. Chiodini, R. J. 1996. Immunology: resistance to paratuberculosis. Vet Clin North Am Food Anim Pract 12:313-43.

29. Chiodini, R. J., and C. A. Rossiter. 1996. Paratuberculosis: a potential zoonosis? Vet Clin North Am Food Anim Pract 12:457-67.

30. Chiodini, R. J., and H. J. Van Kruiningen. 1983. Eastern white-tailed deer as a reservoir of ruminant paratuberculosis. J Am Vet Med Assoc 182:168-9.

31. Chiodini, R. J., H. J. Van Kruiningen, and R. S. Merkal. 1984. Ruminant paratuberculosis (Johne's disease): the current status and future prospects. Cornell Vet 74:218-62.

32. Chiodini, R. J., H. J. Van Kruiningen, R. S. Merkal, W. R. Thayer, Jr., and J. A. Coutu. 1984. Characteristics of an unclassified Mycobacterium species isolated from patients with Crohn's disease. J Clin Microbiol 20:966-71.

33. Clarke, C. J. 1997. The pathology and pathogenesis of paratuberculosis in ruminants and other species. J Comp Pathol 116:217-61.

34. Clarke, C. J., and D. Little. 1996. The pathology of ovine paratuberculosis: gross and histological changes in the intestine and other tissues. J Comp Pathol 114:419-37.

35. Clarke, C. J., I. A. Patterson, K. E. Armstrong, and J. C. Low. 1996. Comparison of the absorbed ELISA and agar gel immunodiffusion test with clinicopathological findings in ovine clinical paratuberculosis. Vet Rec 139:618-21.

36. Cocito, C., P. Gilot, M. Coene, M. de Kesel, P. Poupart, and P. Vannuffel. 1994. Paratuberculosis. Clin Microbiol Rev 7:328-45.

37. Collins, D. M., S. Cavaignac, and G. W. de Lisle. 1997. Use of four DNA insertion sequences to characterize strains of the Mycobacterium avium complex isolated from animals. Mol Cell Probes 11:373-80. 
38. Collins, D. M., D. M. Gabric, and G. W. de Lisle. 1990. Identification of two groups of Mycobacterium paratuberculosis strains by restriction endonuclease analysis and DNA hybridization. J Clin Microbiol 28:1591-6.

39. Collins, D. M., D. M. Stephens, and G. W. de Lisle. 1993. Comparison of polymerase chain reaction tests and faecal culture for detecting Mycobacterium paratuberculosis in bovine faeces. Vet Microbiol 36:289-99.

40. Collins, M. T. 1996. Diagnosis of paratuberculosis. Vet Clin North Am Food Anim Pract 12:357-71.

41. Collins, M. T. 1997. Mycobacterium paratuberculosis: a potential food-borne pathogen? J Dairy Sci 80:3445-8.

42. Collins, M. T., K. B. Kenefick, D. C. Sockett, R. S. Lambrecht, J. McDonald, and J. B. Jorgensen. 1990. Enhanced radiometric detection of Mycobacterium paratuberculosis by using filter-concentrated bovine fecal specimens. J Clin Microbiol 28:25149.

43. Collins, M. T., and D. C. Sockett. 1993. Accuracy and economics of the USDAlicensed enzyme-linked immunosorbent assay for bovine paratuberculosis. J Am Vet Med Assoc 203:1456-63.

44. Collins, M. T., D. C. Sockett, W. J. Goodger, T. A. Conrad, C. B. Thomas, and D. J. Carr. 1994. Herd prevalence and geographic distribution of, and risk factors for, bovine paratuberculosis in Wisconsin. J Am Vet Med Assoc 204:636-41.

45. Collins, M. T., D. C. Sockett, S. Ridge, and J. C. Cox. 1991. Evaluation of a commercial enzyme-linked immunosorbent assay for Johne's disease. J Clin Microbiol 29:272-6.

46. Corti, S., and R. Stephan. 2002. Detection of Mycobacterium avium subspecies paratuberculosis specific IS900 insertion sequences in bulk-tank milk samples obtained from different regions throughout Switzerland. BMC Microbiol 2:15.

47. Cousins, D. V., R. Whittington, I. Marsh, A. Masters, R. J. Evans, and P. Kluver. 1999. Mycobacteria distinct from Mycobacterium avium subsp. paratuberculosis isolated from the faeces of ruminants possess IS900-like sequences detectable IS900 polymerase chain reaction: implications for diagnosis. Mol Cell Probes 13:431-42.

48. Crawford, G. C., M. H. Ziccardi, B. J. Gonzales, L. M. Woods, J. K. Fischer, E. J. Manning, and J. A. Mazet. 2006. Mycobacterium avium subspecies paratuberculosis and Mycobacterium avium subsp. avium infections in a tule elk (Cervus elaphus nannodes) herd. J Wildl Dis 42:715-23.

49. Crohn, B. B., L. Ginzburg, and G. D. Oppenheimer. 2000. Regional ileitis: a pathologic and clinical entity. 1932. Mt Sinai J Med 67:263-8.

50. Czerny, C. P., M. Alex, J. Pricelius, and C. Zeller-Lue. 2001. Development of quantitative PCR tests for the detection of the Orthopox virus adsorption protein gene (ORFD8L) on the Light Cycler. In S. Meuer, Wittwer, C., Nakagawara, K. (ed.), Rapid Cycle Real-Time-PCR. Methods and Applications. Springer Verlag, Heidelberg.

51. Dannenberg, A. M., Jr. 1968. Cellular hypersensitivity and cellular immunity in the pathogensis of tuberculosis: specificity, systemic and local nature, and associated macrophage enzymes. Bacteriol Rev 32:85-102.

52. Dannenberg, A. M., Jr. 1989. Immune mechanisms in the pathogenesis of pulmonary tuberculosis. Rev Infect Dis 11 Suppl 2:S369-78.

53. Davidson, W. R., E. J. Manning, and V. F. Nettles. 2004. Culture and serologic survey for Mycobacterium avium subsp. paratuberculosis infection among southeastern white-tailed deer (Odocoileus virginianus). J Wildl Dis 40:301-6.

54. de Juan, L., A. Mateos, L. Dominguez, J. M. Sharp, and K. Stevenson. 2005. Genetic diversity of Mycobacterium avium subspecies paratuberculosis isolates from goats detected by pulsed-field gel electrophoresis. Vet Microbiol 106:249-57. 
55. de Kesel, M., P. Gilot, M. C. Misonne, M. Coene, and C. Cocito. 1993. Cloning and expression of portions of the 34-kilodalton-protein gene of Mycobacterium paratuberculosis: its application to serological analysis of Johne's disease. J Clin Microbiol 31:947-54.

56. de Lisle, G. W., B. S. Samagh, and J. R. Duncan. 1980. Bovine paratuberculosis II. A comparison of fecal culture and the antibody response. Can J Comp Med 44:18391.

57. Djonne, B., I. Pavlik, P. Svastova, M. Bartos, and G. Holstad. 2005. IS900 restriction fragment length polymorphism (RFLP) analysis of Mycobacterium avium subsp. paratuberculosis isolates from goats and cattle in Norway. Acta Vet Scand 46:13-8.

58. Dorshorst, N. C., M. T. Collins, and J. E. Lombard. 2006. Decision analysis model for paratuberculosis control in commercial dairy herds. Prev Vet Med 75:92-122.

59. Doyle, T. M. 1954. Isolation of Johne's Bacilli from the udders of clinically affected cows. Br Vet J 110:215-18.

60. Dreier, S., J. L. Khol, B. Stein, K. Fuchs, S. Gutler, and W. Baumgartner. 2006. Serological, bacteriological and molecularbiological survey of paratuberculosis (Johne's disease) in Austrian cattle. J Vet Med B Infect Dis Vet Public Health 53:477-81.

61. Dukes, T. W., G. J. Glover, B. W. Brooks, J. R. Duncan, and M. Swendrowski. 1992. Paratuberculosis in saiga antelope (Saiga tatarica) and experimental transmission to domestic sheep. J Wildl Dis 28:161-70.

62. Eda, S., J. P. Bannantine, W. R. Waters, Y. Mori, R. H. Whitlock, M. C. Scott, and C. A. Speer. 2006. A highly sensitive and subspecies-specific surface antigen enzyme- linked immunosorbent assay for diagnosis of Johne's disease. Clin Vaccine Immunol 13:837-44.

63. Ellner, J. J., and R. S. Wallis. 1989. Immunologic aspects of mycobacterial infections. Rev Infect Dis 11 Suppl 2:455-59.

64. Englund, S., A. Ballagi-Pordany, G. Bolske, and K. E. Johansson. 1999. Single PCR and nested PCR with a mimic molecule for detection of Mycobacterium avium subsp. paratuberculosis. Diagn Microbiol Infect Dis 33:163-71.

65. Englund, S., G. Bolske, and K. E. Johansson. 2002. An IS900-like sequence found in a Mycobacterium sp. other than Mycobacterium avium subsp. paratuberculosis. FEMS Microbiol Lett 209:267-71.

66. Feola, R. P., M. T. Collins, and C. J. Czuprynski. 1999. Hormonal modulation of phagocytosis and intracellular growth of Mycobacterium avium ss. paratuberculosis In bovine peripheral blood monocytes. Microb Pathog 26:1-11.

67. Ferreira, R., L. S. Fonseca, and W. Lilenbaum. 2002. Agar gel immunodiffusion test (AGID) evaluation for detection of bovine paratuberculosis in Rio de Janeiro, Brazil. Lett Appl Microbiol 35:173-5.

68. Francis, J., H. M. Macturk, J. Madinaveitia, and G. A. Snow. 1953. Mycobactin, a growth factor for Mycobacterium johnei. I. Isolation from Mycobacterium phlei. Biochem J 55:596-607.

69. Fridriksdottir, V., E. Gunnarsson, S. Sigurdarson, and K. B. Gudmundsdottir. 2000. Paratuberculosis in Iceland: epidemiology and control measures, past and present. Vet Microbiol 77:263-7.

70. Gao, A., J. Odumeru, M. Raymond, S. Hendrick, T. Duffield, and L. Mutharia. 2009. Comparison of milk culture, direct and nested polymerase chain reaction (PCR) with fecal culture based on samples from dairy herds infected with Mycobacterium avium subsp. paratuberculosis. Can J Vet Res 73:58-64.

71. Gerlach, G. F., and P. Valentin-Weigand. 1998. Bovine paratuberculosis: history and results of new efforts to control an old disease. Berl Münch Tierärztl Wochenschr 111:368-73. 
72. Godden, S., S. McMartin, J. Feirtag, J. Stabel, R. Bey, S. Goyal, L. Metzger, J. Fetrow, S. Wells, and H. Chester-Jones. 2006. Heat-treatment of bovine colostrum. II: effects of heating duration on pathogen viability and immunoglobulin G. J Dairy Sci 89:3476-83.

73. Grant, I. R., H. J. Ball, and M. T. Rowe. 1998. Isolation of Mycobacterium paratuberculosis from milk by immunomagnetic separation. Appl Environ Microbiol 64:3153-8.

74. Grant, I. R., C. M. Pope, L. M. O'Riordan, H. J. Ball, and M. T. Rowe. 2000. Improved detection of Mycobacterium avium subsp. paratuberculosis In milk by immunomagnetic PCR. Vet Microbiol 77:369-78.

75. Green, E. P., M. L. Tizard, M. T. Moss, J. Thompson, D. J. Winterbourne, J. J. McFadden, and J. Hermon-Taylor. 1989. Sequence and characteristics of IS900, an insertion element identified in a human Crohn's disease isolate of Mycobacterium paratuberculosis. Nucleic Acids Res 17:9063-73.

76. Griffin, J. F., E. Spittle, C. R. Rodgers, S. Liggett, M. Cooper, D. Bakker, and J. P. Bannantine. 2005. Immunoglobulin G1 enzyme-linked immunosorbent assay for diagnosis of Johne's Disease in red deer (Cervus elaphus). Clin Diagn Lab Immunol 12:1401-9.

77. Groth, W. 1964. Zur Histopathogenese der Paratuberkulose des Schafes. Zbl Vet Med B 11:418-32.

78. Hacker, U., K. Huttner, and M. Konow. 2004. Investigation of serological prevalence and risk factors of paratuberculosis in dairy farms in the state of MecklenburgWestpommerania, Germany. Berl Münch Tierärztl Wochenschr 117:140-4.

79. Hahn, H., and S. H. Kaufmann. 1981. The role of cell-mediated immunity in bacterial infections. Rev Infect Dis 3:1221-50.

80. Hammer, P., C. Kiesner, H. G. Walte, K. Knappstein, and P. Teufel. 2002. Heat resistance of Mycobacterium avium subspecies paratuberculosis in raw milk tested in a pilot plant pasteurizer. Kieler Milchwirtschaftliche Forschungsberichte 54:275-303.

81. Harris, N. B., and R. G. Barletta. 2001. Mycobacterium avium subsp. paratuberculosis in Veterinary Medicine. Clin Microbiol Rev 14:489-512.

82. Hermon-Taylor, J. 2002. Treatment with drugs active against Mycobacterium avium subspecies paratuberculosis can heal Crohn's disease: more evidence for a neglected public health tragedy. Dig Liver Dis 34:9-12.

83. Hermon-Taylor, J., and T. Bull. 2002. Crohn's disease caused by Mycobacterium avium subspecies paratuberculosis: a public health tragedy whose resolution is long overdue. J Med Microbiol 51:3-6.

84. Herthnek, D., and G. Bolske. 2006. New PCR systems to confirm real-time PCR detection of Mycobacterium avium subsp. paratuberculosis. BMC Microbiol 6:87.

85. Herthnek, D., S. Englund, P. T. Willemsen, and G. Bolske. 2006. Sensitive detection of Mycobacterium avium subsp. paratuberculosis in bovine semen by real-time PCR. J Appl Microbiol 100:1095-102.

86. Hilbink, F., D. M. West, G. W. de Lisle, R. Kittelberger, B. D. Hosie, J. Hutton, M. M. Cooke, and M. Penrose. 1994. Comparison of a complement fixation test, a gel diffusion test and two absorbed and unabsorbed ELISAs for the diagnosis of paratuberculosis in sheep. Vet Microbiol 41:107-16.

87. Hill, B. B., M. West, and K. V. Brock. 2003. An estimated prevalence of Johne's disease in a subpopulation of Alabama beef cattle. J Vet Diagn Invest 15:21-5.

88. Holstad, G., O. G. Sigurdardottir, A. K. Storset, J. Tharaldsen, O. Nyberg, J. Schonheit, and B. Djonne. 2005. Description of the infection status in a Norwegian cattle herd naturally infected by Mycobacterium avium subsp. paratuberculosis. Acta Vet Scand 46:45-56. 
89. Horne, H. 1910. Die spezifische chronische Enteritis des Rindes und die Ophthalmound Kutanreaktion mittels Vögeltuberkulin. Berlin Tierärztl Wochenschr 26:109-10.

90. Hulten, K., H. M. El-Zimaity, T. J. Karttunen, A. Almashhrawi, M. R. Schwartz, D. Y. Graham, and F. A. El-Zaatari. 2001. Detection of Mycobacterium avium subspecies paratuberculosis in Crohn's diseased tissues by in situ hybridization. Am J Gastroenterol 96:1529-35.

91. Huntley, J. F., R. H. Whitlock, J. P. Bannantine, and J. R. Stabel. 2005. Comparison of diagnostic detection methods for Mycobacterium avium subsp. paratuberculosis in North American bison. Vet Pathol 42:42-51.

92. Jakobsen, M. B., L. Alban, and S. S. Nielsen. 2000. A cross-sectional study of paratuberculosis in 1155 Danish dairy cows. Prev Vet Med 46:15-27.

93. Jark, U. 1996. Etablierung eines ELISA zur Erkennung subklinischer Paratuberkulose-Infektionen beim Rind. Tierärztliche Hochschule Hannover, Dissertation vet med.

94. Jark, U., I. Ringena, B. Franz, G. F. Gerlach, M. Beyerbach, and B. Franz. 1997. Development of an ELISA technique for serodiagnosis of bovine paratuberculosis. Vet Microbiol 57:189-98.

95. Johnson-Ifearulundu, Y. J., J. B. Kaneene, D. J. Sprecher, J. C. Gardiner, and J. W. Lloyd. 2000. The effect of subclinical Mycobacterium paratuberculosis infection on days open in Michigan, USA, dairy cows. Prev Vet Med 46:171-81.

96. Jorgensen, J. B. 1983. The diagnosis of clinical paratuberculosis in bovines. Commisson of the European Communities. Agricultural Report Eur 9000 EN, 1-8.

97. Jorgensen, J. B. 1982. An improved medium for culture of Mycobacterium paratuberculosis from bovine faeces. Acta Vet Scand 23:325-35.

98. Jorgensen, J. B. 1977. Survival of Mycobacterium paratuberculosis in slurry. Nord Vet Med 29:267-70.

99. Jorgensen, J. B., and P. T. Jensen. 1978. Enzyme-Linked Immunosorbent Assay (ELISA) for detection of antibodies to Mycobacterium paratuberculosis in cattle. Acta Vet Scand 19:310-12.

100. Judge, J., I. Kyriazakis, A. Greig, R. S. Davidson, and M. R. Hutchings. 2006. Routes of intraspecies transmission of Mycobacterium avium subsp. paratuberculosis in rabbits (Oryctolagus cuniculus): a field study. Appl Environ Microbiol 72:398-403.

101. Kalis, C. H., H. W. Barkema, J. W. Hesselink, C. van Maanen, and M. T. Collins. 2002. Evaluation of two absorbed enzyme-linked immunosorbent assays and a complement fixation test as replacements for fecal culture in the detection of cows shedding Mycobacterium avium subspecies paratuberculosis. J Vet Diagn Invest 14:21924.

102. Kanazawa, K., Y. Haga, O. Funakoshi, H. Nakajima, A. Munakata, and Y. Yoshida. 1999. Absence of Mycobacterium paratuberculosis DNA in intestinal tissues from Crohn's disease by nested polymerase chain reaction. J Gastroenterol 34:200-6.

103. Koets, A. P., V. P. Rutten, M. de Boer, D. Bakker, P. Valentin-Weigand, and W. van Eden. 2001. Differential changes in heat shock protein-, lipoarabinomannan-, and purified protein derivative-specific immunoglobulin G1 and G2 isotype responses during bovine Mycobacterium avium subsp. paratuberculosis infection. Infect Immun 69:1492-8.

104. Koo, H. C., Y. H. Park, M. J. Hamilton, G. M. Barrington, C. J. Davies, J. B. Kim, J. L. Dahl, W. R. Waters, and W. C. Davis. 2004. Analysis of the immune response to Mycobacterium avium subsp. paratuberculosis in experimentally infected calves. Infect Immun 72:6870-83.

105. Kopecna, M., S. Ondrus, I. Literak, J. Klimes, A. Horvathova, M. Moravkova, M. Bartos, I. Trcka, and I. Pavlik. 2006. Detection of Mycobacterium avium subsp. 
paratuberculosis in two brown bears in the central European Carpathians. J Wildl Dis 42:691-5.

106. Kormendy, B., T. Kopal, T. Balint, M. Szilagyi, and L. Beki. 1989. Economic losses caused by paratuberculosis in a dairy herd: case report. Acta Vet Hung 37:45-53.

107. Lambrecht, R. S., and M. T. Collins. 1992. Mycobacterium paratuberculosis. Factors that influence mycobactin dependence. Diagn Microbiol Infect Dis 15:239-46.

108. Larsen, A. B., and K. E. Kopecky. 1970. Mycobacterium paratuberculosis in reproductive organs and semen of bulls. Am J Vet Res 31:255-8.

109. Larsen, A. B., R. S. Merkal, and R. C. Cutlip. 1975. Age of cattle as related to resistance to infection with Mycobacterium paratuberculosis. Am J Vet Res 36:255-7.

110. Larsen, A. B., R. S. Merkal, and T. H. Vardaman. 1956. Survival time of Mycobacterium paratuberculosis. Am J Vet Res 17:549-51.

111. Larsen, A. B., and H. W. Moon. 1972. Experimental Mycobacterium paratuberculosis infection in chickens. Am J Vet Res 33:1231-5.

112. Lisby, G., J. Andersen, K. Engbaek, and V. Binder. 1994. Mycobacterium paratuberculosis in intestinal tissue from patients with Crohn's disease demonstrated by a nested primer polymerase chain reaction. Scand J Gastroenterol 29:923-9.

113. Littell, R., Miliken G., Stroup, W., Wolfinger, R. 1999. SAS system for mixed models., USA, NC, Inc., SAS Institute.

114. Lovell, R., M. Levi, and J. Francis. 1944. Studies on the survival of johne's bacilli. J Comp Pathol 54:120-29.

115. Marco, I., M. Ruiz, R. Juste, J. M. Garrido, and S. Lavin. 2002. Paratuberculosis in free-ranging fallow deer in Spain. J Wildl Dis 38:629-32.

116. Marek, J. 1910. Enteritis paratuberculosa. Altrorv Lapok, 33,504.

117. McCaughan, C. J. 1989. On-farm management of Johne's disease., p. 53-60. In A. R. Milner and P. R. Wood (ed.), Johne's Disease: Current trends in research, diagnosis and management. CSIRO, East Melbourne.

118. McClure, H. M., R. J. Chiodini, D. C. Anderson, R. B. Swenson, W. R. Thayer, and J. A. Coutu. 1987. Mycobacterium paratuberculosis infection in a colony of stumptail macaques (Macaca arctoides). J Infect Dis 155:1011-9.

119. McDonald, W. L., K. J. O'Riley, C. J. Schroen, and R. J. Condron. 2005. Heat inactivation of Mycobacterium avium subsp. paratuberculosis in milk. Appl Environ Microbiol 71:1785-9.

120. McKenna, S. L., H. W. Barkema, G. P. Keefe, and D. C. Sockett. 2006. Agreement between three ELISAs for Mycobacterium avium subsp. paratuberculosis in dairy cattle. Vet Microbiol 114:285-91.

121. Merkal, R. S. 1973. Laboratory diagnosis of bovine paratuberculosis. J Am Vet Med Assoc 163:1100-2.

122. Merkal, R. S. 1984. Paratuberculosis: advances in cultural, serologic, and vaccination methods. J Am Vet Med Assoc 184:939-43.

123. Merkal, R. S. 1985. Paratuberculosis: prevalence, diagnosis, prevention and treatment. Bovine Proceedings 17:64-66.

124. Merkal, R. S., J. P. Kluge, W. S. Monlux, A. B. Larsen, K. E. Kopecky, L. Y. Quinn, and R. P. Lehmann. 1968. Experimental paratuberculosis in sheep after oral, intratracheal, or intravenous inoculation: histochemical localization of hydrolase activities. Am J Vet Res 29:985-94.

125. Merkal, R. S., K. E. Kopecky, and A. B. Larsen. 1970. Immunologic mechanisms in bovine paratuberculosis. Am J Vet Res 31:475-85.

126. Merkal, R. S., A. B. Larsen, and K. E. Kopecky. 1968. Comparison of examination and test methods for early detection of paratuberculous cattle. Am J Vet Res 29:15338. 
127. Merkal, R. S., D. L. Whipple, J. M. Sacks, and G. R. Snyder. 1987. Prevalence of Mycobacterium paratuberculosis in ileocecal lymph nodes of cattle culled in the United States. J Am Vet Med Assoc 190:676-80.

128. Meyer zu Vilsendorf, U. 1995. Untersuchungen zur Bekämpfung der Paratuberkulose mittels Merzung serologisch oder kulturell positiver Rinder. Tierärztliche Hochschule Hannover, Dissertation vet med.

129. Millar, D., J. Ford, J. Sanderson, S. Withey, M. Tizard, T. Doran, and J. Hermon-Taylor. 1996. IS900 PCR to detect Mycobacterium paratuberculosis in retail supplies of whole pasteurized cows' milk in England and Wales. Appl Environ Microbiol 62:3446-52.

130. Miller, D. S., M. T. Collins, B. B. Smith, P. R. Anderson, J. Kramsky, G. Wilder, and A. Hope. 2000. Specificity of four serologic assays for Mycobacterium avium ss paratuberculosis in llamas and alpacas: a single herd study. J Vet Diagn Invest 12:34553.

131. Milner, A. R., W. N. Mack, K. J. Coates, J. Hill, I. Gill, and P. Sheldrick. 1990. The sensitivity and specificity of a modified ELISA for the diagnosis of Johne's disease from a field trial in cattle. Vet Microbiol 25:193-8.

132. Ministerium für Umwelt und Naturschutz, L.-u. V. N.-R.-W. 2000. Paratuberkulose der Rinder. Leitlinien des Landes Nordrhein-Westfalen für den Schutz und die Sanierung von Rinderbeständen., p. 972, vol. II C 2-2181-3667. Ministerblatt NordRhein-Westfalen, Köln.

133. Momotani, E., D. L. Whipple, A. B. Thiermann, and N. F. Cheville. 1988. Role of $\mathrm{M}$ cells and macrophages in the entrance of Mycobacterium paratuberculosis into domes of ileal Peyer's patches in calves. Vet Pathol 25:131-7.

134. Monti, P. 2006. Serumdiagnostik der bovinen Mycobacterium avium subspecies paratuberculosis-Infektion: Vergleich von zwei Testsystemen. Universität Zürich, Dissertation vet med.

135. Moss, M. T., E. P. Green, M. L. Tizard, Z. P. Malik, and J. Hermon-Taylor. 1991. Specific detection of Mycobacterium paratuberculosis by DNA hybridisation with a fragment of the insertion element IS900. Gut 32:395-8.

136. Muskens, J., H. W. Barkema, E. Russchen, K. van Maanen, Y. H. Schukken, and D. Bakker. 2000. Prevalence and regional distribution of paratuberculosis in dairy herds in The Netherlands. Vet Microbiol 77:253-61.

137. Mutschler, E. 1981. Arzneimittelwirkungen. Ein Lehrbuch für Pharmakologen und Pharmazeuten, Chemiker und Biologen. Wiss. Verlagsgesellschaft mbH, Stuttgart.

138. Möbius, P., G. Luyven, H. Hotzel, and H. Kohler. 2008. High genetic diversity among Mycobacterium avium subsp. paratuberculosis strains from German cattle herds shown by combination of IS900 restriction fragment length polymorphism analysis and mycobacterial interspersed repetitive unit-variable-number tandem-repeat typing. J Clin Microbiol 46:972-81.

139. Naser, S. A., K. Hulten, I. Shafran, D. Y. Graham, and F. A. El-Zaatari. 2000. Specific seroreactivity of Crohn's disease patients against p35 and p36 antigens of M. avium subsp. paratuberculosis. Vet Microbiol 77:497-504.

140. Nielsen, S. S., S. M. Thamsborg, H. Houe, and V. Bitsch. 2000. Bulk-tank milk ELISA antibodies for estimating the prevalence of paratuberculosis in Danish dairy herds. Prev Vet Med 44:1-7.

141. Nordlund, K. V., W. J. Goodger, J. Pelletier, and M. T. Collins. 1996. Associations between subclinical paratuberculosis and milk production, milk components, and somatic cell counts in dairy herds. J Am Vet Med Assoc 208:1872-6.

142. Olsen, I., M. Tryland, H. G. Wiker, and L. J. Reitan. 2001. AhpC, AhpD, and a secreted 14-kilodalton antigen from Mycobacterium avium subsp. paratuberculosis di- 
stinguish between paratuberculosis and bovine tuberculosis in an enzyme-linked immunosorbent assay. Clin Diagn Lab Immunol 8:797-801.

143. Ott, S. L., S. J. Wells, and B. A. Wagner. 1999. Herd-level economic losses associated with Johne's disease on US dairy operations. Prev Vet Med 40:179-92.

144. Paolicchi, F. A., A. Vagnozzi, C. G. Morsella, A. E. Verna, A. R. Massone, E. L. Portiansky, and E. J. Gimeno. 2001. Paratuberculosis in red deer (Cervus elaphus): an immunohistochemical study. J Vet Med B Infect Dis Vet Public Health 48:313-20.

145. Paolicchii, F. A., M. J. Zumarraga, A. Gioffre, P. Zamorano, C. Morsella, A. Verna, A. Cataldi, A. Alito, and M. Romano. 2003. Application of different methods for the diagnosis of paratuberculosis in a dairy cattle herd in Argentina. J Vet Med B Infect Dis Vet Public Health 50:20-6.

146. Park, K. T., J. Ahn, W. C. Davis, H. C. Koo, N. H. Kwon, W. K. Jung, J. M. Kim, S. K. Hong, and Y. H. Park. 2006. Analysis of the seroprevalence of bovine paratuberculosis and the application of modified absorbed ELISA to field sample testing in Korea. J Vet Sci 7:349-54.

147. Patterson, D. S., W. M. Allen, and S. Berrett. 1967. Plasma enzyme levels in clinical Johne's disease of cattle. Vet Rec 81:435-7.

148. Patterson, D. S., W. M. Allen, S. Berrett, L. N. Ivins, and D. Sweasey. 1968. Some biochemical aspects of clinical Johne's disease in cattle. Res Vet Sci 9:117-29.

149. Pavlik, I., A. Horvathova, L. Dvorska, J. Bartl, P. Svastova, R. du Maine, and I. Rychlik. 1999. Standardisation of restriction fragment length polymorphism analysis for Mycobacterium avium subspecies paratuberculosis. J Microbiol Methods 38:15567.

150. Pavlik, I., L. Matlova, J. Bartl, P. Svastova, L. Dvorska, and R. Whitlock. 2000. Parallel faecal and organ Mycobacterium avium subsp. paratuberculosis culture of different productivity types of cattle. Vet Microbiol 77:309-24.

151. Perez, V., J. Tellechea, J. J. Badiola, M. Gutierrez, and J. F. Garcia Marin. 1997. Relation between serologic response and pathologic findings in sheep with naturally acquired paratuberculosis. Am J Vet Res 58:799-803.

152. Perez, V., J. Tellechea, J. M. Corpa, M. Gutierrez, and J. F. Garcia Marin. 1999. Relation between pathologic findings and cellular immune responses in sheep with naturally acquired paratuberculosis. Am J Vet Res 60:123-7.

153. Pöll, K. 1960. Über die Zuverlässigkeit diagnostischer Verfahren bei der Paratuberkulose und ihre Verbreitung am Niederrhein. Universität Gießen, Dissertation vet med.

154. Quist, C. F., V. F. Nettles, E. J. Manning, D. G. Hall, J. K. Gaydos, T. J. Wilmers, and R. R. Lopez. 2002. Paratuberculosis in key deer (Odocoileus virginianus clavium). J Wildl Dis 38:729-37.

155. Rademaker, J. L., M. M. Vissers, and M. C. Te Giffel. 2007. Effective heat inactivation of Mycobacterium avium subsp. paratuberculosis in raw milk contaminated with naturally infected feces. Appl Environ Microbiol 73:4185-90.

156. Raizman, E. A., S. J. Wells, S. M. Godden, J. Fetrow, and J. M. Oakes. 2007. The associations between culling due to clinical Johne's disease or the detection of Mycobacterium avium subsp. paratuberculosis fecal shedding and the diagnosis of clinical or subclinical diseases in two dairy herds in Minnesota, USA. Prev Vet Med 80:16678.

157. Rankin, J. D. 1961. The non-specificity of a complement fixation test used in the diagnosis of johne's disease in cattle. Res. Vet. Sci. 2:89-95.

158. Reichel, M. P., R. Kittelberger, M. E. Penrose, R. M. Meynell, D. Cousins, T. Ellis, L. M. Mutharia, E. A. Sugden, A. H. Johns, and G. W. de Lisle. 1999. Comparison of serological tests and faecal culture for the detection of Mycobacterium avium 
subsp. paratuberculosis infection in cattle and analysis of the antigens involved. Vet Microbiol 66:135-50.

159. Ridge, S. E. 1993. Cultivation of Mycobacterium paratuberculosis from bovine fecal samples by using elements of the Roche MB Check system. J Clin Microbiol 31:4005.

160. Ridge, S. E., I. R. Morgan, D. C. Sockett, M. T. Collins, R. J. Condron, N. W. Skilbeck, and J. J. Webber. 1991. Comparison of the Johne's absorbed EIA and the complement-fixation test for the diagnosis of Johne's disease in cattle. Aust Vet J 68:253-7.

161. Ririe, K. M., R. P. Rasmussen, and C. T. Wittwer. 1997. Product differentiation by analysis of DNA melting curves during the polymerase chain reaction. Anal Biochem 245: $154-60$.

162. Ris, D. R., K. L. Hamel, and J. M. Ayling. 1988. The detection of Mycobacterium paratuberculosis in bovine faeces by isolation and the comparison of isolation with the examination of stained smears by light microscopy. N Z Vet J 36:112-4.

163. Ritacco, V., K. Kremer, T. van der Laan, J. E. Pijnenburg, P. E. de Haas, and D. van Soolingen. 1998. Use of IS901 and IS1245 in RFLP typing of Mycobacterium avium complex: relatedness among serovar reference strains, human and animal isolates. Int J Tuberc Lung Dis 2:242-51.

164. Robbe-Austerman, S., I. A. Gardner, B. V. Thomsen, D. G. Morrical, B. M. Martin, M. V. Palmer, C. O. Thoen, and C. Ewing. 2006. Sensitivity and specificity of the agar-gel-immunodiffusion test, ELISA and the skin test for detection of paratuberculosis in United States Midwest sheep populations. Vet Res 37:553-64.

165. Rosenberger, G. 1994. Paratuberkulose (Johne'sche Krankheit). p. 756-60. In G. Rosenberger (ed.), Krankheiten des Rindes., 3. ed. Blackwell, Berlin.

166. Ryan, P., M. W. Bennett, S. Aarons, G. Lee, J. K. Collins, G. C. O'Sullivan, J. O'Connell, and F. Shanahan. 2002. PCR detection of Mycobacterium paratuberculosis in Crohn's disease granulomas isolated by laser capture microdissection. Gut 51:665-70.

167. Ryan, P., R. G. Kelly, G. Lee, J. K. Collins, G. C. O'Sullivan, J. O'Connell, and F. Shanahan. 2004. Bacterial DNA within granulomas of patients with Crohn's disease-detection by laser capture microdissection and PCR. Am J Gastroenterol 99:1539-43.

168. Salgado, M., E. J. Manning, and M. T. Collins. 2005. Performance of a Johne's disease enzyme-linked immunosorbent assay adapted for milk samples from goats. J Vet Diagn Invest 17:350-4.

169. Saunders, V. F., G. J. Eamens, M. J. Turner, and T. M. Jessep. 2003. Identification of a new RFLP type of Mycobacterium avium subsp paratuberculosis in epidemiological tracing of bovine Johne's disease. Aust Vet J 81:564-6.

170. Schaaf, J., W. Beerwerth, and S. Grodde. 1956. Über die Paratuberkulose des Rindes, ihre Verbreitung, Diagnose und Bekämpfung. Rindertuberkulose. Med Tierheilkunde 8: 144-54.

171. Schall, R. 1991. Estimation in generalised linear models with random effects. Biometrika 78:719-27.

172. Schneider, F. 2003. Entwicklung einer ,seminested PCR“ und einer „Real-Time PCR“ zum nachweis von M. avium ssp. paratuberculosis beim Rind. Uni München, Dissertation vet med.

173. Schonenbrucher, H., A. Abdulmawjood, K. Failing, and M. Bulte. 2008. New triplex real-time PCR assay for detection of Mycobacterium avium subsp. paratuberculosis in bovine feces. Appl Environ Microbiol 74:2751-8.

174. Scott, H. M., O. Sorensen, J. T. Wu, E. Y. Chow, and K. Manninen. 2007. Seroprevalence of and agroecological risk factors for Mycobacterium avium subspecies 
paratuberculosis and neospora caninum infection among adult beef cattle in cow-calf herds in Alberta, Canada. Can Vet J 48:397-406.

175. Sechi, L. A., M. Mura, F. Tanda, A. Lissia, A. Solinas, G. Fadda, and S. Zanetti. 2001. Identification of Mycobacterium avium subsp. paratuberculosis in biopsy specimens from patients with Crohn's disease identified by in situ hybridization. J Clin Microbiol 39:4514-7.

176. Seitz, S. E., L. E. Heider, W. D. Heuston, S. Bech-Nielsen, D. M. Rings, and L. Spangler. 1989. Bovine fetal infection with Mycobacterium paratuberculosis. J Am Vet Med Assoc 194:1423-6.

177. Sharon, K. H. 1992. The options in diagnosis ruminant paratuberculosis. Vet Med 87:1122-32.

178. Sherman, D. M. 1985. Current concepts in Johne's disease. Vet Med 80:77-82.

179. Sherman, D. M., J. M. Gay, D. S. Bouley, and G. H. Nelson. 1990. Comparison of the complement-fixation and agar gel immunodiffusion tests for diagnosis of subclinical bovine paratuberculosis. Am J Vet Res 51:461-5.

180. Shin, S. J., D. Cho, and M. T. Collins. 2008. Diagnosis of bovine paratuberculosis by a novel enzyme-linked immunosorbent assay based on early secreted antigens of Mycobacterium avium subsp. paratuberculosis. Clin Vaccine Immunol 15:1277-81.

181. Sivakumar, P., B. N. Tripathi, N. Singh, and A. K. Sharma. 2006. Pathology of naturally occurring paratuberculosis in water buffaloes (Bubalus bubalis). Vet Pathol 43:455-62.

182. Smithwick, R. W., M. R. Bigbie, Jr., R. B. Ferguson, M. A. Karlix, and C. K. Wallis. 1995. Phenolic acridine orange fluorescent stain for mycobacteria. J Clin Microbiol 33:2763-4.

183. Sockett, D. C., D. J. Carr, and M. T. Collins. 1992. Evaluation of conventional and radiometric fecal culture and a commercial DNA probe for diagnosis of Mycobacterium paratuberculosis infections in cattle. Can J Vet Res 56:148-53.

184. Sockett, D. C., T. A. Conrad, C. B. Thomas, and M. T. Collins. 1992. Evaluation of four serological tests for bovine paratuberculosis. J Clin Microbiol 30:1134-9.

185. Soumya, M. P., R. M. Pillai, P. X. Antony, H. K. Mukhopadhyay, and V. N. Rao. 2009. Comparison of faecal culture and IS900 PCR assay for the detection of Mycobacterium avium subsp. paratuberculosis in bovine faecal samples. Vet Res Commun 33:781-91.

186. Speer, C. A., M. C. Scott, J. P. Bannantine, W. R. Waters, Y. Mori, R. H. Whitlock, and S. Eda. 2006. A novel enzyme-linked immunosorbent assay for diagnosis of Mycobacterium avium subsp. paratuberculosis infections (Johne's Disease) in cattle. Clin Vaccine Immunol 13:535-40.

187. Stabel, J. R. 2000. Cytokine secretion by peripheral blood mononuclear cells from cows infected with Mycobacterium paratuberculosis. Am J Vet Res 61:754-60.

188. Stabel, J. R. 1996. Production of gamma-interferon by peripheral blood mononuclear cells: an important diagnostic tool for detection of subclinical paratuberculosis. J Vet Diagn Invest 8:345-50.

189. Stabel, J. R. 2000. Transitions in immune responses to Mycobacterium paratuberculosis. Vet Microbiol 77:465-73.

190. Stabel, J. R., and J. P. Bannantine. 2005. Development of a nested PCR method targeting a unique multicopy element, ISMap02, for detection of Mycobacterium avium subsp. paratuberculosis in fecal samples. J Clin Microbiol 43:4744-50.

191. Stabel, J. R., and A. Lambertz. 2004. Efficacy of pasteurization conditions for the inactivation of Mycobacterium avium subsp. paratuberculosis in milk. J Food Prot 67:2719-26. 
192. Stacey, A. R. 1986. Isolation of Mycobacterium avium-intracellulare-scrofulaceum complex from faeces of patients with AIDS. Br Med J (Clin Res Ed) 293:1194.

193. Stevenson, K., V. M. Hughes, L. de Juan, N. F. Inglis, F. Wright, and J. M. Sharp. 2002. Molecular characterization of pigmented and nonpigmented isolates of Mycobacterium avium subsp. paratuberculosis. J Clin Microbiol 40:1798-804.

194. Stevenson, K., and J. M. Sharp. 1997. The contribution of molecular biology to Mycobacterium avium subspecies Paratuberculosis research. Vet J 153:269-86.

195. Stratmann, J., B. Strommenger, K. Stevenson, and G. F. Gerlach. 2002. Development of a peptide-mediated capture PCR for detection of Mycobacterium avium subsp. paratuberculosis in milk. J Clin Microbiol 40:4244-50.

196. Suenaga, K., Y. Yokoyama, K. Okazaki, and Y. Yamamoto. 1995. Mycobacteria in the intestine of Japanese patients with inflammatory bowel disease. Am J Gastroenterol 90:76-80.

197. Sugden, E. A., B. W. Brooks, N. M. Young, D. C. Watson, K. H. Nielsen, A. H. Corner, C. Turcotte, A. Michaelides, and R. B. Stewart. 1991. Chromatographic purification and characterization of antigens A and D from Mycobacterium paratuberculosis and their use in enzyme-linked immunosorbent assays for diagnosis of paratuberculosis in sheep. J Clin Microbiol 29:1659-64.

198. Sugden, E. A., A. H. Corner, B. S. Samagh, B. W. Brooks, C. Turcotte, K. H. Nielsen, R. B. Stewart, and J. R. Duncan. 1989. Serodiagnosis of ovine paratuberculosis, using lipoarabinomannan in an enzyme-linked immunosorbent assay. Am J Vet Res 50:850-4.

199. Sugden, E. A., B. S. Samagh, D. R. Bundle, and J. R. Duncan. 1987. Lipoarabinomannan and lipid-free arabinomannan antigens of Mycobacterium paratuberculosis. Infect Immun 55:762-70.

200. Sugden, E. A., K. Stilwell, and A. Michaelides. 1997. A comparison of lipoarabinomannan with other antigens used in absorbed enzyme immunoassays for the serological detection of cattle infected with Mycobacterium paratuberculosis. J Vet Diagn Invest 9:413-7.

201. Sweeney, R. W. 1996. Transmission of paratuberculosis. Vet Clin North Am Food Anim Pract 12:305-12.

202. Sweeney, R. W., D. E. Jones, P. Habecker, and P. Scott. 1998. Interferon-gamma and interleukin 4 gene expression in cows infected with Mycobacterium paratuberculosis. Am J Vet Res 59:842-7.

203. Sweeney, R. W., R. H. Whitlock, C. L. Buckley, and P. A. Spencer. 1995. Evaluation of a commercial enzyme-linked immunosorbent assay for the diagnosis of paratuberculosis in dairy cattle. J Vet Diagn Invest 7:488-93.

204. Tasara, T., L. E. Hoelzle, and R. Stephan. 2005. Development and evaluation of a Mycobacterium avium subspecies paratuberculosis (MAP) specific multiplex PCR assay. Int J Food Microbiol 104:279-87.

205. Thoen, C. O., W. D. Richards, and J. L. Jarnagin. 1977. Mycobacteria isolated from exotic animals. J Am Vet Med Assoc 170:987-90.

206. Tiwari, A., J. A. VanLeeuwen, I. R. Dohoo, G. P. Keefe, and A. Weersink. 2008. Estimate of the direct production losses in Canadian dairy herds with subclinical Mycobacterium avium subspecies paratuberculosis infection. Can Vet J 49:569-76.

207. Tripathi, B. N., S. Periasamy, O. P. Paliwal, and N. Singh. 2006. Comparison of IS900 tissue PCR, bacterial culture, johnin and serological tests for diagnosis of naturally occurring paratuberculosis in goats. Vet Microbiol 116:129-37.

208. Tryland, M., I. Olsen, T. Vikoren, K. Handeland, J. M. Arnemo, J. Tharaldsen, B. Djonne, T. D. Josefsen, and L. J. Reitan. 2004. Serologic survey for antibodies 
against Mycobacterium a vium subsp. paratuberculosis in free-ranging cervids from Norway. J Wildl Dis 40:32-41.

209. Tsai, S. J., L. J. Hutchinson, and A. Zarkower. 1989. Comparison of dot immunobinding assay, enzyme-linked immunosorbent assay and immunodiffusion for serodiagnosis of paratuberculosis. Can J Vet Res 53:405-10.

210. Twort, F. W. 1914. The experimental production of johne's disease in some of the laboratory animals. Veterinary News 11:79-81.

211. Twort, F. W., and G. L. Y. Ingram. 1912. A Method for isolating and cultivating Mycobacterium enteritidis chronicae pseudotuberculose bovis johne and some experiments on the preparations of a diagnostic vaccine for pseudotuberculose enteritis of bovines. Proceedings of the Royal Society of London 84:517-43.

212. Van Kruiningen, H. J. 1999. Lack of support for a common etiology in Johne's disease of animals and Crohn's disease in humans. Inflamm Bowel Dis 5:183-91.

213. Van Leeuwen, J. A., L. Forsythe, A. Tiwari, and R. Chartier. 2005. Seroprevalence of antibodies against bovine leukemia virus, bovine viral diarrhea virus, Mycobacterium avium subspecies paratuberculosis, and Neospora caninum in dairy cattle in Saskatchewan. Can Vet J 46:56-8.

214. Vannuffel, P., P. Gilot, B. Limbourg, B. Naerhuyzen, C. Dieterich, M. Coene, L. Machtelinckx, and C. Cocito. 1994. Development of species-specific enzyme-linked immunosorbent assay for diagnosis of Johne's disease in cattle. J Clin Microbiol 32:1211-6.

215. Vary, P. H., P. R. Andersen, E. Green, J. Hermon-Taylor, and J. J. McFadden. 1990. Use of highly specific DNA probes and the polymerase chain reaction to detect Mycobacterium paratuberculosis in Johne's disease. J Clin Microbiol 28:933-7.

216. vom Schloß, A. 2000. Auswertung eines Sanierungsverfahrens zur Bekämpfung der Paratuberkulose in Rinderbeständen in Nordrhein-Westfalen. Tierärztliche Hochschule Hannover, Dissertation vet med.

217. Wade, K. M., and R. L. Quas. 1993. Solution to a system of equations involving a first-order autoregressive process. J Dairy Sci 76:3026-32.

218. Waldner, C. L., G. L. Cunningham, E. D. Janzen, and J. R. Campbell. 2002. Survey of Mycobacterium avium subspecies paratuberculosis serological status in beef herds on community pastures in Saskatchewan. Can Vet J 43:542-6.

219. Waters, W. R., J. M. Miller, M. V. Palmer, J. R. Stabel, D. E. Jones, K. A. Koistinen, E. M. Steadham, M. J. Hamilton, W. C. Davis, and J. P. Bannantine. 2003. Early induction of humoral and cellular immune responses during experimental Mycobacterium avium subsp. paratuberculosis infection of calves. Infect Immun 71:5130-8.

220. Weber, A., R. Gurke, K. Bauer, and K. Schreyer. 1992. Bacterial studies on the occurrence of Mycobacterium paratuberculosis in fecal samples of zoo ruminants. Berl Münch Tierärztl Wochenschr 105:161-4.

221. Wells, S. J., M. T. Collins, K. S. Faaberg, C. Wees, S. Tavornpanich, K. R. Petrini, J. E. Collins, N. Cernicchiaro, and R. H. Whitlock. 2006. Evaluation of a rapid fecal PCR test for detection of Mycobacterium avium subsp. paratuberculosis in dairy cattle. Clin Vaccine Immunol 13:1125-30.

222. White, W. B., D. L. Whipple, J. R. Stabel, and C. A. Bolin. 1994. Comparison of cellular and extracellular proteins expressed by various isolates of Mycobacterium paratuberculosis and other mycobacterial species. Am J Vet Res 55:1399-405.

223. Whitlock, R. H., and C. Buergelt. 1996. Preclinical and clinical manifestations of paratuberculosis (including pathology). Vet Clin North Am Food Anim Pract 12:34556. 
224. Whitlock, R. H., L. T. Hutchinson, L. T. Glickman, R. Meinersman, C. Rossiter, J. Bruce, R. Merkal, and J. Dick. 1986. Paratuberculosis (Johne's disease) update. Bovine Pract 21:24-30.

225. Whitlock, R. H., S. J. Wells, R. W. Sweeney, and J. Van Tiem. 2000. ELISA and fecal culture for paratuberculosis (Johne's disease): sensitivity and specificity of each method. Vet Microbiol 77:387-98.

226. Whittington, R. J., A. F. Hope, D. J. Marshall, C. A. Taragel, and I. Marsh. 2000. Molecular epidemiology of Mycobacterium avium subsp. paratuberculosis: IS900 restriction fragment length polymorphism and IS1311 polymorphism analyses of isolates from animals and a human in Australia. J Clin Microbiol 38:3240-8.

227. Widjojoatmodjo, M. N., A. C. Fluit, R. Torensma, G. P. Verdonk, and J. Verhoef. 1992. The magnetic immuno polymerase chain reaction assay for direct detection of salmonellae in fecal samples. J Clin Microbiol 30:3195-9.

228. Winterhoff, C. 2000. Paratuberkulose-Diagnostik in Milch: Erreger-und Antikörpernachweis mittels PCR und ELISA. Tierärztliche Hochschule Hannover, Dissertation vet med.

229. Wittwer, C. 2001. Rapid Cycle Real-Time PCR. In S. Meuer, Wittwer, C., Nakagawara, K. (ed.), Rapid Cycle Real-Time PCR. Methods and Applikations. Springer Verlag, Heidelberg.

230. Wolfinger, R., and O'Connell. 1993. Generalised linear mixed models: A pseudolikelihood approach. J of Statistical Computation and Simulation 48:233-43.

231. Woodruff, T. S., W. P. Shulaw, S. Bech-Nielsen, G. F. Hoffsis, E. Spangler, and L. E. Heider. 1991. Serodiagnosis of bovine paratuberculosis by use of a dot enzymelinked immunosorbent assay. Am J Vet Res 52:217-21.

232. Yokomizo, Y., M. Kishima, Y. Mori, and K. Nishimori. 1991. Evaluation of enzyme-linked immunosorbent assay in comparison with complement fixation test for the diagnosis of subclinical paratuberculosis in cattle. J Vet Med Sci 53:577-84.

233. Yokomizo, Y., R. S. Merkal, and P. A. Lyle. 1983. Enzyme-linked immunosorbent assay for detection of bovine immunoglobulin G1 antibody to a protoplasmic antigen of Mycobacterium paratuberculosis. Am J Vet Res 44:2205-7.

234. Yokomizo, Y., H. Yugi, and R. S. Merkal. 1985. A method for avoiding falsepositive reactions in an enzyme-linked immunosorbent assay (ELISA) for the diagnosis of bovine paratuberculosis. Nippon Juigaku Zasshi 47:111-9. 


\section{E r k l är u n g e n}

1. Hiermit erkläre ich, dass diese Arbeit weder in gleicher noch in ähnlicher Form bereits anderen Prüfungsbehörden vorgelegen hat.

Weiter erkläre ich, dass ich mich an keiner anderen Hochschule um einen Doktorgrad beworben habe.

Göttingen, den

(Unterschrift)

2. Hiermit erkläre ich eidesstattlich, dass diese Dissertation selbständig und ohne unerlaubte Hilfe angefertigt wurde.

Göttingen, den

(Unterschrift) 
